\title{
O SETOR SUPERMERCADISTA NO BRASIL NOS ANOS 1990
}

\section{UMBERTO ANTONIO SESSO FILHO}

Tese apresentada à Escola Superior de Agricultura "Luiz de Queiroz", Universidade de São Paulo, para obtenção do título de Doutor em Ciências, Área de Concentração: Economia Aplicada.

P I R A C I C A B A

Estado de São Paulo - Brasil

Março-2003 


\section{O SETOR SUPERMERCADISTA NO BRASIL NOS ANOS 1990}

\section{UMBERTO ANTONIO SESSO FILHO}

Engenheiro Agrônomo

Orientador: Prof. Dr. JOAQUIM JOSÉ MARTINS GUILHOTO

Tese apresentada à Escola Superior de Agricultura "Luiz de Queiroz", Universidade de São Paulo, para obtenção do título de Doutor em Ciências, Área de Concentração: Economia Aplicada.

P I R A C I C A B A

Estado de São Paulo - Brasil

Março-2003 
Dados Internacionais de Catalogação na Publicação (CIP)

DIVISÃO DE BIBLIOTECA E DOCUMENTAÇÃO - ESALQ/USP

\author{
Sesso Filho, Umberto Antonio \\ O setor supemercadista no Brasil nosanos 1990 / Umberto Antonio \\ Sesso Filho. - - Pira cic aba, 2003.
}

$195 \mathrm{p}$.

Tese (doutorado) - Escola Superior de Agricultura Luiz de Queiroz, 2003. Bibliografia.

1. Brasil 2. Supermerc ados I. Título

CDD 658.878

"Permitida a cópia total ou parcial deste documento, desde que citada a fonte - $\mathrm{O}$ autor" 


\section{AGRADECIMENTOS}

Meus sinceros agradecimentos à minha família e à Patrícia pelo incentivo ao meu trabalho e atenção aos meus problemas.

Ao Prof. Joaquim José Martins Guilhoto pela orientação do trabalho e voto de confiança em minha pessoa.

Aos professores, funcionários e colegas do Departamento de Economia, Administração e Sociologia da ESALQ/USP por fazer do meu curso de doutorado um período importante de minha vida.

Ao amigo Ariel Wilder, pois os resultados de nossas discussões sobre diversos temas e artigos publicados foram incorporados ao texto da tese.

Aos professores Alexandre Barros (ESALQ), Pedro Marques (ESALQ) e Francisco Crócomo (Unimep) que muito contribuíram fazendo sugestões para o desenvolvimento do trabalho.

À Associação Brasileira de Supermercados, na pessoa de Fátima de Cássia Merlin (gerente de pesquisa), que forneceu dados importantes para a realização da pesquisa.

À CAPES/CNPq pelo apoio financeiro. 


\section{SUMÁRIO}

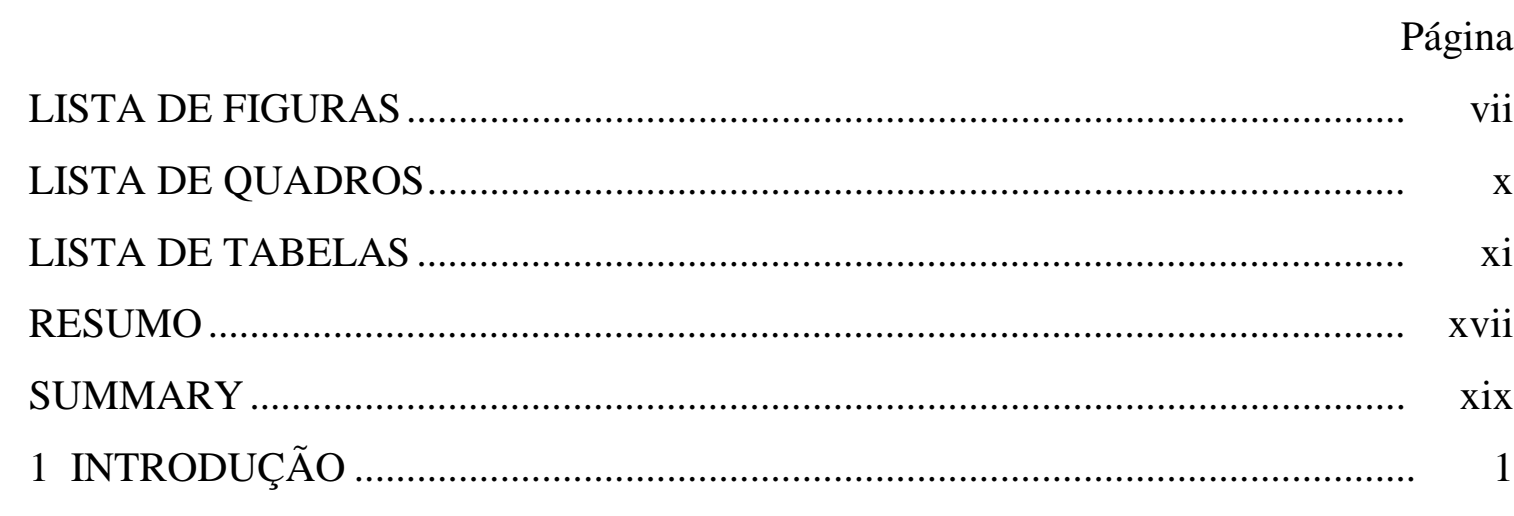

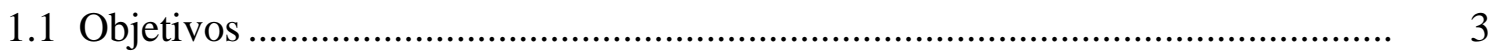

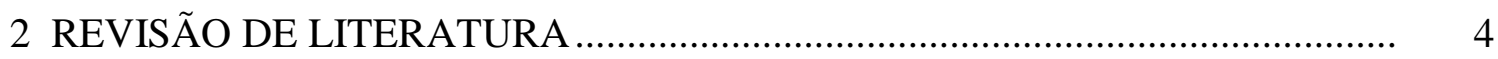

2.1 Origem dos supermercados ........................................................................

2.2 Supermercados no Brasil.............................................................................. 8

2.2.1 1953-65 Introdução dos supermercados no Brasil .............................................. 8

2.2.2 1965-74 Rápida expansão do setor supermercadista ......................................... 11

2.2.3 1975-85 Desaceleração do crescimento …………………………………….... 14

2.2.4 1986-94 Adaptação à crise econômica............................................................ 16

2.2.5 1995- Modernização do setor supermercadista.................................................. 18

2.2.5.1 Definição do setor supermercadista ........................................................... 18

2.2.5.2 Estabilização econômica e comportamento do consumidor ............................ 19

2.2.5.3 Lançamentos de novos produtos ............................................................... 27

2.2.5.4 Entrada de novas empresas varejistas …………......................................... 29

2.2.5.5 Novas tecnologias ................................................................................ 32

2.2.5.6 Estratégias das grandes redes de supermercados ......................................... 37

2.2.5.7 Estratégias das pequenas empresas supermercadistas.................................... 43

2.2.5.8 Modificações da relação fornecedor-varejista ............................................... 44 
2.2.5.9 Dificuldades para a expansão do setor supermercadista.

2.2.5.10 Síntese das tendências da distribuição de alimentos na década de1990

2.2.6 Síntese da expansão dos supermercados no Brasil e importância econômica .

3 METODOLOGIA

3.1 Teoria Insumo-produto 54

3.2 Análise setorial 59

3.2.1 Ligações intersetoriais e setores-chave 59

3.2.1.1 Índices de Rasmussen-Hirschman. 60

3.2.1.2 Campo de influência 61

3.2.1.3 Abordagem GHS: índices puros de ligação 62

3.2.2 Multiplicadores 65

3.2.2.1 Multiplicadores de produção. 65

3.2.2.2 Multiplicadores de emprego 66

3.2.2.3 Multiplicadores de renda. 67

3.2.2.4 Multiplicadores de impostos 68

3.2.3 Produto Interno Bruto setorial. 68

3.3 Desagregação do setor supermercadista..... 72

3.3.1 Nova proposta metodológica

3.3.1.1 Valores a preços básicos das mercadorias comercializadas pelos supermercados

3.3.2 Deflacionamento de valores dos setores da Matriz de Insumo-produto.

4 RESULTADOS E DISCUSSÃO

4.1 Produto Interno Bruto do setor supermercadista..

4.2 Geração de emprego.

4.3 Geração de renda 110

4.4 Geração de Imposto de Circulação de Mercadorias e Serviços 124

4.5 Multiplicadores de produção e índices de ligações intersetoriais 
4.5.1 Multiplicadores de produção...................................................................... 128

4.5.2 Índices de ligações intersetoriais.............................................................. 135

4.6 Comparação dos resultados da metodologia tradicional e nova proposta metodológica ........................................................................ 155

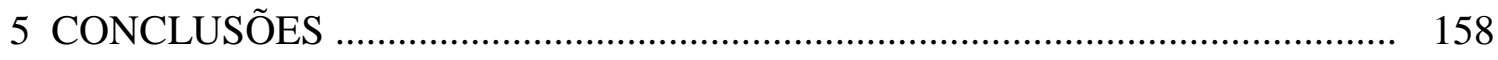

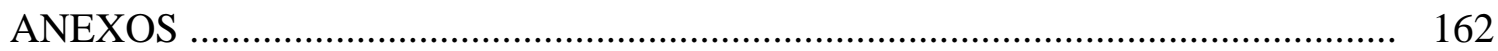

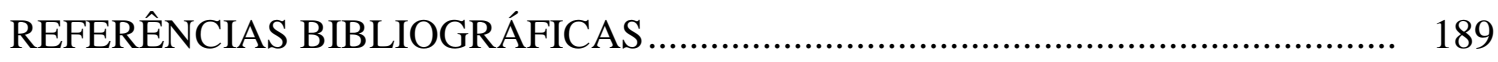




\section{LISTA DE FIGURAS}

Página

1 Lançamentos de novos produtos no Brasil no período 1997/2001 ……………...... 27

2 Lançamentos de novos produtos no Brasil em algumas categorias

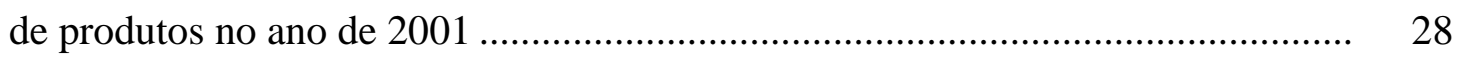

3 Automação comercial no setor supermercadista brasileiro...................................... 34

4 Participação das cinco maiores redes no faturamento total do setor supermercadista em países selecionados (\%) em 1997 .......................................... 39

5 Transformações do setor supermercadista na década de 1990................................ 49

6 Evolução do índice do faturamento das 300 maiores empresas do setor e participação das 20 maiores empresas no faturamento anual

7 Participação das seções no faturamento total das lojas do setor supermercadista no ano de 2000

8 Participação do número de empregos diretos, indiretos e induzidos sobre o total de empregos gerados pelos setores no ano de 1999n para a variação da demanda final de um milhão de reais 
9 Participação da renda direta, indireta e induzida sobre o total gerado pelos setores no ano de 1999n para a variação da demanda final de um milhão de reais

10 Produtividade do trabalho e capacidade de geração de renda dos setores da economia para o ano de 1999n (nova proposta metodológica).

11 Índices de ligações intersetoriais de Rasmussen-Hirschman para o ano de 1990

12 Índices de ligações intersetoriais de Rasmussen-Hirschman para o ano de 1995

13 Índices de ligações intersetoriais de Rasmussen-Hirschman para o ano de 1999

14 Índices de ligações intersetoriais de Rasmussen-Hirschman para o ano de $1995 \mathrm{n}$

15 Índices de ligações intersetoriais de Rasmussen-Hirschman para o ano de 1999 n

16 Índices de ligações intersetoriais puros normalizados totais dos anos de 1990, 1995 e 1999 (metodologia tradicional)

17 Índices de ligações intersetoriais puros normalizados totais dos anos de 1995 e 1999, setor 35-Supermercados desagregado pela nova proposta metodológica 
19 Campo de influência dos setores para o ano de 1995 ..................................... 149

20 Campo de influência dos setores para o ano de 1999 ..................................... 149

21 Campo de influência dos setores para o ano de 1995n .................................. 150

22 Campo de influência dos setores para o ano de 1999n .................................. 150

23 Campo de influência dos setores para o ano de 1999n com endogeneização do componente Consumo das famílias (com exclusão do novo setor) …........................................................... 152

24 Campo de influência dos setores para o ano de 1999n com endogeneização do componente Consumo das famílias

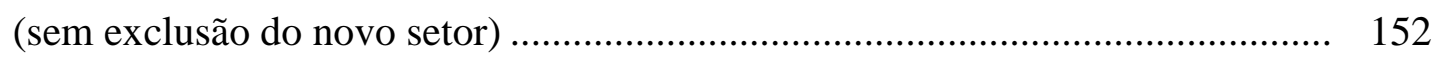




\section{LISTA DE QUADROS}

Página

1 Principais tendências da distribuição de alimentos no Brasil na década de 1990.

2 Síntese da expansão dos supermercados no Brasil

3 Matriz de insumo-produto para dois setores

4 Realocação dos valores a preços básicos, impostos e margens das mercadorias comercializadas pelos supermercados dentro da Matriz de Recursos e Usos

5 Comparação da determinação de setores-chave de acordo com a geração de emprego (GE) e renda (GR), multiplicador de produção (MP) tipo II e índices de ligação de Rasmussen-Hirschman (RH), puros normalizados (GHS) e campo de influência (campo) para o ano de 1999n 


\section{LISTA DE TABELAS}

Página

1 Classificação de lojas do setor supermercadista ................................................. 19

2 Classificação das famílias das principais metrópoles brasileiras em 1995/96

3 Produto Interno Bruto per capita do Brasil, 1990-2000

4 Desempenho da indústria de alimentos entre 1996/2000.

5 Elasticidades-renda da despesa de produtos e serviços no Brasil em 1995/96......

6 Número de famílias, tamanho médio da família, recebimento mensal familiar e recebimento per capita nas 10 classes de recebimento mensal familiar para da Pesquisa de Orçamentos Familiares (POF)

7 Elasticidade-renda da despesa de alimentos no Brasil em 1995/96

8 Elasticidade-renda do consumo físico de alimentos no Brasil em 1995/96.

9 Nomes das empresas estrangeiras atuantes no país, país de origem, faturamento bruto e ano de entrada no mercado brasileiro.

10 Modificação das margens de comercialização em supermercados antes e após a implementação do Plano Real (1994) 
11 Dados gerais e indicadores de produtividade do trabalho no setor supermercadista

12 Brasil - Super e Hipermercados - Aquisições das duas maiores redes em 2000

13 Evolução da participação do faturamento bruto total (\%) e número de lojas das 20 maiores cadeias de supermercados no setor.

14 Concentração do setor supermercadista brasileiro em 2000

15 Concentração e internacionalização de capital de sete indústrias de alimentos no Brasil na década de 1990 (em \%)

16 Brasil - Principais associações de super e hipermercados

17 Indicadores econômicos do auto-serviço alimentar brasileiro no período 1995/2000

18 Evolução do faturamento das 300 maiores empresas do setor supermercadista e participação no faturamento das 20 maiores redes.

19 Empregos diretos de setores da economia brasileira.

20 Participação das seções de produtos no faturamento total do setor supermercadista em 1999/2000 e faturamento em valor nominal.

21 Valores a preços básicos dos produtos comercializados pelos supermercados, margens e impostos em R \$ milhões nominais e participação no Consumo das Famílias da Matriz de Recursos e Usos (\%)......... 
22 Deflatores implícitos setoriais da Matriz de Insumo-produto para os anos de 1990, 1995 e 1999

23 Produto interno bruto do setor supermercadista, pessoal ocupado e produtividade do trabalho

24 Produto interno bruto do setor supermercadista, pessoal ocupado e produtividade do trabalho obtidos com as matrizes da nova proposta metodológica.

25 Participação dos setores no produto interno bruto (PIB setorial), pessoal ocupado e produtividade do trabalho no sistema do setor 35-Supermercados

26 Multiplicadores de emprego tipos I e II e empregos totais (médias) dos setores agrupados

27 Multiplicadores de emprego tipos I e II, valores obtidos de acordo com a metodologia tradicional

28 Multiplicadores de emprego tipos I e II, valores obtidos de acordo com a nova proposta metodológica

29 Geração de emprego total para a variação de um milhão de reais da demanda final e ordenação, resultados obtidos para a metodologia tradicional

30 Geração de empregos diretos (dir), indiretos (indir), induzidos (indu) pela variação da demanda final de um milhão de reais (metodologia tradicional)

31 Geração de empregos diretos (dir), indiretos (indir), induzidos (indu) e total dos setores (nova proposta metodológica) 
32 Decomposição dos multiplicadores de emprego tipos I e II do setor 35-Supermercados (metodologia tradicional)

33 Decomposição dos multiplicadores de emprego tipos I e II do setor 35-Supermercados (nova proposta metodológica) 106

34 Geração de empregos por setor dada uma variação da demanda final de R 1 bilhão do setor 35-Supermercados (metodologia tradicional)

35 Geração de empregos por setor dada uma variação da demanda final de R \$ 1 bilhão da demanda final do setor 35-Supermercados (nova proposta metodológica)

36 Classificação dos setores de acordo com a capacidade de geração de renda para um aumento da demanda de um milhão de reais, valores em $\mathrm{R} \$$ mil (metodologia tradicional)....

37 Classificação dos setores de acordo com a capacidade de geração de renda para um aumento da demanda de um milhão de reais, valores em $\mathrm{R} \$$ mil (nova metodologia)

38 Multiplicadores de renda dos setores, valores obtidos de acordo para a metodologia tradicional

39 Multiplicadores de renda dos setores, valores obtidos de acordo com a nova proposta metodológica

40 Geração de renda direta (dir), indireta (indir) e induzida (indu) dos setores para uma variação da demanda final de um milhão de reais, valores em $\mathrm{R} \$$ mil (metodologia tradicional) 
41 Geração de renda direta (dir), indireta (indir) e induzida (indu) dos setores para uma variação da demanda final de um milhão de reais, valores em $\mathrm{R} \$$ mil (nova proposta metodológica)

42 Geração de renda por setor dada uma variação da demanda final de $\mathrm{R}$ \$ 1 milhão do setor 35-Supermercados, valores em $\mathrm{R}$ \$ mil (metodologia tradicional)

43 Geração de renda por setor dada uma variação de $\mathrm{R}$ \$ milhão da demanda final do setor 35-Supermercados, valores em $\mathrm{R} \$$ mil (nova proposta metodológica)

44 Capacidade de geração de ICMS total para um aumento de produção de R\$ 1 milhão (valores em R \$ mil, “o” é ordenação)

45 Multiplicadores de produção tipos I e II e ordenação dos setores de acordo com os valores do multiplicador tipo II (metodologia tradicional)

46 Multiplicadores de produção tipos I e II e ordenação (o) dos setores de acordo com os valores do multiplicador tipo II (nova proposta metodológica)...

47 Decomposição do multiplicador de produção tipos I e II do setor 35-Supermercados, resultados para a metodologia tradicional

48 Decomposição do multiplicador de produção tipos I e II do setor 35-Supermercados, resultados para a nova proposta metodológica

49 Índices de ligações intersetoriais de Rasmussen-Hirschman (metodologia tradicional)

50 Índices de ligações intersetoriais de Rasmussen-Hirschman (nova proposta metodológica) 
51 Índices de ligações intersetoriais puros normalizados e classificação pelo valor total para os anos de 1995 e 1999, desagregação do setor supermercados pela metodologia tradicional

52 Índices de ligações intersetoriais puros normalizados e classificação pelo valor total para os anos de 1995 e 1999, desagregação do setor supermercados pela nova proposta metodológica

53 Diferenças dos indicadores econômicos calculados para a metodologia tradicional e nova proposta metodológica (1999n-1999)

54 Classificação das diferenças do multiplicador de produção tipo I e II calculado para a metodologia tradicional e nova proposta metodológica 


\title{
O SETOR SUPERMERCADISTA NO BRASIL NOS ANOS 1990
}

\author{
Autor: UMBERTO ANTONIO SESSO FILHO \\ Orientador: Prof. Dr. JOAQUIM JOSÉ MARTINS GUILHOTO
}

\section{RESUMO}

O setor supermercadista no Brasil passou por profundas transformações na década de 1990 tais como o processo de consolidação das maiores empresas, automação comercial e uso de transferência eletrônica de informações. O objetivo do estudo foi analisar o impacto das modificações deste setor sobre a economia utilizando a teoria insumo-produto. Para tanto, o novo setor Supermercados foi desagregado do setor Comércio na matriz de insumo-produto do Brasil para os anos de 1990, 1995 e 1999 e os indicadores econômicos referentes à geração de emprego, renda, produção e impostos e índices de ligações intersetoriais foram calculados para todos os setores da economia. Para os anos de 1995 e 1999 também foi aplicada uma nova metodologia para análise setorial do varejo, a qual consiste em incorporar os valores a preços básicos das mercadorias comercializadas como custos operacionais do setor supermercadista. Além disso, foi estimado o produto interno bruto setorial do novo setor Supermercados para os anos indicados anteriormente. As principais conclusões da pesquisa são de que o setor Supermercados apresenta grande importância na geração de emprego, renda, produção e imposto sobre circulação de mercadorias e serviços (ICMS) para o período 1990-1999 e o PIB setorial é de aproximadamente 5\% do produto interno bruto nacional. Para o ano de 1999, valores obtidos pela nova proposta metodológica, os supermercados eram capazes de gerar 154 empregos totais, cerca de $R \$ 400$ mil em salários e $R \$ 110$ mil em 
impostos (ICMS) para uma variação da demanda final de um milhão de reais. O maior impacto da variação da produção dos supermercados em termos de geração de emprego, renda e produção ocorre sobre os setores Agropecuária, Outros produtos alimentares, Beneficiamento de produtos vegetais, Indústria de laticínios, Comércio, Serviços prestados às famílias e Aluguel de imóveis. O impacto sobre a Agropecuária e indústria de alimentos ocorre principalmente por efeito indireto e sobre os setores de serviços por efeito induzido. Outras indústrias passam a indicar maior influência das vendas dos supermercados sobre sua produção, emprego e renda, principalmente Artigos plásticos, Artigos do vestuário e Serviços prestados às empresas. Isto indica a diversificação dos produtos comercializados pelos supermercados com itens não-alimentos, principalmente com a abertura de hipermercados, e maiores gastos com propaganda e outros serviços prestados às empresas. 


\title{
THE SUPERMARKET SECTOR IN BRAZIL IN THE YEARS 1990
}

\author{
Author: UMBERTO ANTONIO SESSO FILHO \\ Advisor: Prof. Dr. JOAQUIM JOSÉ MARTINS GUILHOTO
}

\section{SUMMARY}

The Supermarket sector in Brazil went through deep transformations in the decade of 1990, such as: a) the process of consolidation of the largest companies; b) commercial automation; and c) use of electronic transfer of information. The objective of the study is to analyze the impact of the modifications occurred in this sector on the economy, using the input-output theory. To do so, the new Supermarkets sector were extracted from the Trade sector of the input-output matrix of Brazil for the years 1990, 1995 and 1999 and the economic indicators referring to the employment, income, production, taxes, and inter-sector linkages were calculated for all the sectors of the economy. For the years 1995 and 1999 a new methodology was also applied for sectorial analysis of the supermarket sector, which consists of incorporating the values, at basic prices, of the goods traded as operational costs in the Supermarket sector. Besides, the sectorial gross domestic product (GDP) of the new Supermarket sector was estimated for the years indicated previously. The main conclusions of the research are that the Supermarket sector is an important one in generating employment, income, production and sales taxes (ICMS) for the period 1990-1999. The GDP of the Supermarket complex is of approximately $5 \%$ of the national GDP. For the year of 1999, values obtained using the new methodology show that the supermarkets were capable to generate, for a variation of $\mathrm{R} \$ 1$ million of the final demand: a) 154 new jobs; b) $\mathrm{R} \$ 400$ thousand in 
wages; and c) R\$ 110 thousand in taxes (ICMS). The largest impact of the variation of the supermarkets production in terms of employment generating, income and production occurs on the following sectors: a) Agricultural; b) Other Food Products; c) Processing of Vegetable Products; d) Dairy Industry; e) Trade; f) Services Rendered to Families; and g) Rents. The impact on the Agricultural and Food industry happens mainly by indirect effect and on the sectors of services by induced effect. Other industries started to indicate a larger influence of the sales of the supermarkets on its production, employment and income, mainly in Plastic Goods, Clothing and Services Rendered to the Companies. This indicates: a) the diversification of the products marketed by the supermarkets, mainly non-food items, related with the opening of hypermarkets; and b) larger expenses with marketing and other services rendered to the companies. 


\section{INTRODUÇÃO}

Como será analisado detalhadamente na revisão de literatura, o supermercado foi introduzido no Brasil no início da década de 1950, mas foi apenas na segunda metade da década de 1960 que o equipamento ${ }^{1}$ se tornou importante no varejo de alimentos, sendo que a partir do início da década seguinte passaria a comercializar a maior parte dos produtos adquiridos pela população brasileira, principalmente alimentos.

Durante a década de 1980, o setor acompanhou a crise da economia brasileira, voltando a apresentar altas taxas de crescimento na segunda metade da década de 1990. Neste período distinguem-se duas fases, a primeira com altas taxas de inflação e diminuição da renda nacional e outra caracterizada pela estabilização da economia, na qual o setor supermercadista sofreu grandes transformações. As modificações do ambiente macroeconômico causaram o aumento da demanda, atraindo inúmeras novas empresas nacionais e estrangeiras para o setor. Dentro desta fase de grande crescimento, os supermercados passaram a utilizar-se de novas tecnologias, destacando-se a automação comercial, transferência eletrônica de dados e as ferramentas da Resposta Eficiente ao Consumidor (ECR), as quais tornaram possível a diminuição de custos e crescimento das empresas.

No fim da década de 1990 verificou-se um ciclo de fusões e aquisições que aumentou a concentração do setor, o maior poder de negociação das maiores empresas passou a pressionar fornecedores e pequenas firmas, levantando dúvidas sobre a sobrevivência da maioria das lojas independentes. Algumas pequenas firmas passaram a se unir em associações buscando diminuição de custos de compra e distribuição e outras vantagens como treinamento de funcionários e propaganda conjunta.

\footnotetext{
${ }^{1}$ o termo equipamento se refere à forma de comercialização utilizada pelo setor supermercadista e se diferencia de outras por características como auto-serviço, utilização de gôndolas para exposição dos produtos e disponibilidade de cestas e carrinhos para os clientes.
} 
As transformações citadas têm impacto direto sobre fatores como geração de empregos, produção e renda não apenas dentro do setor supermercadista como também nos outros setores da economia. A análise setorial utilizando a teoria insumo-produto foi a metodologia escolhida para mensurar o impacto das modificações do setor supermercadista sobre seus indicadores econômicos e de outros setores da economia, tornando possível determinar quais as indústrias que sofrem maior influência destas transformações no varejo de alimentos.

Considerando-se o período 1994/99 como o momento das grandes transformações do setor supermercadista, foram escolhidos os anos de 1990, 1995 e 1999 para a desagregação do setor Supermercados na matriz de insumo-produto do Brasil, permitindo calcular indicadores econômicos para esta atividade econômica e analisar sua influência sobre o sistema. Além disso, foi desenvolvida uma nova proposta metodológica para analisar este setor específico, incorporando as mercadorias comercializadas em seus custos operacionais, permitindo comparar os resultados obtidos com os indicadores de outras indústrias.

O texto apresenta inicialmente uma análise do desenvolvimento do setor supermercadista no Brasil desde a década de 1950 até o final dos anos 1990, com ênfase para o período compreendido entre 1995 e 2000. Posteriormente, a metodologia utilizada para a análise setorial é detalhada no capítulo teórico sobre a teoria insumo-produto e desagregação do setor supermercadista na matriz de insumo-produto do Brasil para os anos de 1990, 1995 e 1999. A seguir são apresentados os resultados obtidos para os multiplicadores de emprego, renda, impostos e produção e os índices de ligações intersetoriais do setor supermercadista para os anos citados, os indicadores econômicos são analisados baseando-se na revisão de literatura anteriormente realizada. As conclusões resumem os principais resultados da pesquisa e indicam tópicos importantes para trabalhos futuros e propostas para estimular o desenvolvimento do setor supermercadista no Brasil. 


\section{$1.1 \quad$ Objetivos}

Analisar o setor supermercadista brasileiro durante a década de 1990 utilizando a teoria insumo-produto, avaliando sua importância na economia e o impacto de suas transformações baseando-se nos indicadores econômicos a serem calculados. Especificamente, pretende-se:

a) Desagregar o setor na matriz insumo-produto do Brasil nos anos de 1990, 1995 e 1999

b) Calcular índices de ligações intersetoriais Rasmussen-Hirschmann, índices puros (GHS) e campo de influência.

c) Calcular os multiplicadores de produção, emprego, renda e impostos (ICMS);

d) Calcular o Produto Interno Bruto do setor.

Utilizando a metodologia proposta e baseando-se na revisão de literatura apresentada, foram estabelecidas as seguintes hipóteses sobre os resultados da pesquisa no início de seu desenvolvimento:

a) $\mathrm{O}$ setor supermercadista é um setor-chave na economia quando analisados os multiplicadores de emprego, renda, produção e índices de ligações intersetoriais;

b) Ao longo da dédada de 1990, o número de empregos diretos do setor supermercadista gerados por determinado valor monetário da demanda final diminuiu;

c) A massa de salários por determinado valor monetário da demanda final do setor supermercadista diminuiu ao longo da década de 1990 e

d) O Produto Interno Bruto do setor aumentou durante a década de 1990. 


\section{REVISÃO DE LITERATURA}

\subsection{Origem dos supermercados}

Nas três primeiras décadas do século XX, o varejo nos EUA foi dominado por lojas independentes e cadeias de mercearias que utilizavam o sistema de atendimento em balcão, os principais serviços destes estabelecimentos eram o atendimento personalizado, pedido por telefone, crédito e entregas em domicílio. As redes de mercearias se formaram pela expansão do número de lojas, impulsionada pela necessidade de dispersão dos pontos de venda devido à pequena capacidade de mobilidade dos compradores, pois os meios de comunicação e transporte eram escassos (Cyrillo, 1987).

A expressão auto-serviço (self-service), sistema no qual o cliente escolhe os produtos sem a ajuda de funcionários, foi utilizada pela primeira vez em 1912 por comerciantes do estado da Califórnia (EUA) para definir a forma de operação de suas lojas (Abras, 1993). A origem do supermercado moderno data de 1915-1916, quando foram inauguradas as primeiras lojas Alpha Beta Markets e Piggly Wiggly, respectivamente nos estados da Califórnia e Tenessee nos Estados Unidos (Connor \& Schiek, 1997). Estes estabelecimentos adotavam o auto-serviço, catracas para controlar a entrada de clientes e vendiam somente à vista (Abras, 1993). As lojas pioneiras do formato supermercado foram a King Kuller e a Big Bear, abertas na década de trinta também nos Estados Unidos (Abras, 1993). A denominação supermercado (supermarket) surgiu da influência do cinema, no qual a palavra "super" era grandemente empregada (Abras, 1993).

A adoção do auto-serviço permitia a diminuição de custos com mão-de-obra, eliminava os pedidos por telefone e entregas a domicílio. A idéia era diminuir as 
margens de comercialização e aumentar o giro das mercadorias. A implementação das novas idéias promoveu a queda dos preços e a luta pelos clientes (Cyrillo, 1987).

Inicialmente, os armazéns eram adaptados para funcionar com auto-serviço, assim, eram oferecidos aos clientes carrinhos e cestas para que escolhessem os produtos dentro da área de estoque das antigas lojas tradicionais e pagassem na saída. Após constatar o sucesso da nova forma de comercialização, os empresários abriram lojas mais semelhantes aos supermercados existentes atualmente, com área de vendas relativamente menor que os armazéns anteriormente adaptados (Connor \& Schiek, 1997).

A partir da década de 1920, alguns fatores contribuíram para a expansão do autoserviço. Inicialmente, foi implementado um imposto com alíquota crescente de acordo com o número de lojas da empresa, fator que prejudicou as grandes cadeias de mercearias que praticavam margens de comercialização baixas por loja. Outro fator importante foi a diminuição da vantagem de obter economias pecuniárias das cadeias, pois lojas independentes se uniram em associações para obter maior volume de compras e maior poder de barganha junto aos fornecedores. Em seguida, o Patman Act determinou a eliminação das diferenças de preços de comercialização dos fornecedores, extinguindo as economias pecuniárias (Cyrillo, 1987).

O terceiro e decisivo fator para a expansão do setor supermercadista foi a diminuição do poder aquisitivo da população americana durante a Grande Depressão (final da década de 1920 e início da de 1930), obrigando os varejistas a implementar inovações (Cyrillo, 1987). Durante este período, o supermercado surgiu como uma alternativa às lojas convencionais do período com atendimento personalizado em balcão, pois o novo formato de loja oferecia produtos a preços menores, tornando-se um grande atrativo para a população que sofria forte diminuição do poder aquisitivo no período (Connor \& Schiek, 1997).

O novo equipamento atraiu principalmente clientes das grandes cadeias, os quais possuíam menor poder aquisitivo. Os clientes de alta renda permaneceram em sua maioria leais aos serviços personalizados das lojas independentes, como os pedidos por telefone e as entregas a domicílio. Portanto, rapidamente muitas lojas de grandes redes 
foram transformadas em supermercados. Na década de 1930, a cadeia A\&P substituiu 933 lojas de atendimento em balcão por 204 supermercados, a Kroger e a Safeway eliminaram juntas 600 lojas substituindo-as por 61 supermercados (Cyrillo, 1987).

Devido ao fato do consumidor não ser assistido em suas escolhas como no atendimento pessoal, o sistema de auto-serviço deixava a decisão de compra totalmente para o cliente, o qual passava a ser influenciado pelas embalagens dos produtos, propaganda dentro da loja e nos meios de comunicação. Portanto, a introdução dos supermercados aumentou a importância das marcas e embalagens, estimulando os gastos com propaganda por parte da indústria (Connor \& Schiek, 1997).

No período da Segunda Guerra Mundial, apesar das dificuldades impostas a todas as atividades, escassez de alimentos e mão-de-obra, o novo equipamento (supermercado) se consolidou como importante meio de distribuição de alimentos e outros produtos. Nesta fase, com a falta de alimentos, as prateleiras vazias foram preenchidas com mercadorias não alimentícias para melhorar a aparência do interior das lojas. Após a guerra, os consumidores já haviam se acostumado a adquirir as mercadorias não-alimentícias nos supermercados e as compras esporádicas se tornaram habituais. A venda destes produtos passou a representar parte importante do faturamento dos supermercados (Cyrillo, 1987).

Durante o período pós-guerra, o aumento do poder aquisitivo da população norte americana estimulou a indústria a aumentar o serviço e conveniência de seus produtos. A existência de inúmeras possibilidades de combinações produto/serviço levou as empresas a realizar um grande número de lançamentos de novos itens, passando a enfrentar uma limitação inicial para a introdução do bem no mercado que era o menor espaço nas prateleiras dos supermercados, pois estes possuíam área de vendas média relativamente pequena. As empresas varejistas reagiram ao problema aumentando o tamanho das lojas, assim como oferecendo um número maior de itens, marcas e serviços como estacionamento próprio, brinquedos para as crianças e carrinhos mais modernos (Connor \& Schiek, 1997).

Nas décadas de 1940-50, surgiram caixas registradoras mais rápidas e lojas ainda maiores e mais modernas, oferecendo produtos de maior conveniência como carnes 
embaladas. Posteriormente, nas décadas de 1960-70, fatores importantes como urbanização, aumento da população e da renda per capita influenciaram o aumento do tamanho das lojas e motivaram as empresas a instalar lojas nos subúrbios, atingindo mercados ainda não explorados (Connor \& Schiek, 1997). Os novos conceitos estabelecidos pelo auto-serviço se difundiram pelo mundo durante este período, divulgados principalmente pelos fornecedores de equipamentos e mercadorias. Em 1955, o sistema era empregado em lojas de 52 países (Abras, 1993).

No final da década de 1960, as inovações realizadas nas lojas, tais como grandes estacionamentos, ar condicionado e venda de bens duráveis, causaram o aumento dos custos operacionais, levando muitas empresas ao prejuízo e levando à necessidade de aumentar as margens de comercialização (Cyrillo, 1987).

A partir da década de 1970, a economia americana passou por controle de preços, aumento das taxas de inflação e produtividade decrescente. As modificações citadas provocaram a diminuição das margens praticadas pelas empresas, as lojas independentes diminuíram seu número e participação nas vendas enquanto as redes buscaram novos mercados e adotaram a estratégia de diminuição de custos. Terminava a revolução dos supermercados na economia norte americana e iniciava-se o período de adoção de novas tecnologias, tais como caixas eletrônicos e transferência eletrônica de informações, objetivando-se a diminuição de custos operacionais. A competição entre as maiores empresas se tornou mais forte, pois com a estagnação do consumo e menores margens de comercialização o crescimento apenas é possível por meio da diminuição da participação no mercado do concorrente (Connor \& Schiek, 1997).

Nas décadas de 1980/90, os supermercados passaram a enfrentar a concorrência de lojas de conveniência, as quais são menores, de mais fácil acesso e com menor número de itens; além de outros pontos de venda de alimentos que se tornaram importantes, como postos de gasolina (Connor \& Schiek, 1997). 


\subsection{Supermercados no Brasil}

Os supermercados surgiram no Brasil na década de 50, mas foi apenas a partir do final da década de 60 que estes se desenvolveram mais rapidamente, aumentando sua participação no faturamento do varejo e se estabelecendo como o principal equipamento de distribuição de alimentos no país.

Desde a implantação da primeira loja de auto-serviço, a expansão do setor supermercadista foi afetada pelas variáveis macroeconômicas das fases pelas quais passou a sociedade brasileira, tais como inflação, mudanças de impostos, desenvolvimento da indústria de alimentos, urbanização e planos de estabilização. Baseando-se na literatura, pode-se dividir o histórico do desenvolvimento dos supermercados no Brasil em 5 fases:

- 1953-65 Introdução dos Supermercados no Brasil;

- 1965-74 Rápida Expansão do Setor Supermercadista;

- 1975-85 Desaceleração do Crescimento;

- 1986-94 Adaptação à Crise Econômica; e

- 1995 - $\quad$ Modernização do Setor Supermercadista

As características de cada uma das fases pelas quais passaram os supermercados desde sua introdução no país até o final da década de 1990 são discutidas a seguir.

\subsubsection{3-65 Introdução dos Supermercados no Brasil}

As primeiras tentativas de implantação de lojas de auto-serviço no país datam do final da década de 40, com adoção de um regime parcial no qual o consumidor escolhia alguns produtos sem a ajuda de um balconista (Cyrillo,1987). Porém, a primeira loja a utilizar um sistema completo de auto-serviço foi instalada na cidade de São José dos Campos - SP pela Tecelagem Parayba em janeiro de 1953, a qual possuía mil metros quadrados de área de vendas e foi resultado da adaptação de um antigo armazém que passou a funcionar como auto-serviço (Abras, 1993). 
Diferentemente do que ocorreu nos Estados Unidos, onde o supermercado surgiu como resposta à crise econômica em uma tentativa de diminuir custos, o Brasil passava por um período de grande desenvolvimento durante a década de 50, apesar de apresentar diversos problemas sociais e econômicos (Cyrillo, 1987). Durante a atuação de dois governos, o de Getúlio Vargas e Juscelino Kubitschek, o crescimento da economia foi acompanhado do crescimento da inflação e o aumento de qualidade de vida pretendida pelos governos não atingiu igualmente todos os brasileiros, a constante carestia de parte da população preocupava os envolvidos com o projeto nacional desenvolvimentista, que apresentava como solução para a diminuição da pobreza a industrialização do país (Abras, 1993).

Em relação à comercialização, a missão norte-americana Klein e Saks apontaria em 1954 os principais problemas a serem enfrentados na circulação de mercadorias: lucros excessivos obtidos pelos intermediários devido à assimetria de informação, falta de agilidade no escoamento da produção e necessidade de ampliar as estradas e o número de armazéns (Abras, 1993).

Apesar dos problemas citados, a oferta de alimentos aumentou a uma taxa anual de 4,5\% na década de 1950 , valor superior à taxa anual de crescimento da população de $3,1 \%$. Porém, o aumento da produção de alimentos deveu-se principalmente à utilização de novas terras para o cultivo e não de aumento de produtividade, o que causou o distanciamento das áreas produtivas dos crescentes centros urbanos, agravando os problemas do precário sistema de comercialização agrícola (Baer, 1996). Concomitantemente, as altas taxas de crescimento da renda nacional e a urbanização (crescimento da população urbana de 5,4\% ao ano na década de 1950) proporcionavam a criação de grandes centros urbanos e demanda crescente, promovendo o aumento do fluxo de mercadorias. O varejo tradicional com atendimento personalizado não apresentava capacidade de atender às exigências das transformações da comercialização. Desta forma, o supermercado surgiu como uma nova opção de equipamento para atender ao grande volume a ser comercializado, exigido pela demanda e oferta de alimentos em crescimento (Cyrillo,1987). 
Em 1953, além da loja dos funcionários da Tecelagem Parayba, duas outras importantes iniciativas devem ser citadas, em 24 de agosto daquele ano foi inaugurada a loja 1 do Supermercado Sirva-se, na cidade de São Paulo, cujo layout e equipamentos seguiam o modelo norte-americano e apresentavam características muito similares aos modernos supermercados. Empreendimento pioneiro, a primeira loja dos Supermercados Peg-Pag seria inaugurada próximo do natal de 1953 também na cidade de São Paulo. Esta loja é considerada uma "escola de supermercado", pois os proprietários contrataram funcionários especializados para trabalhar em cada seção/departamento e o treinamento dos empregados era permanente. As estratégias de vendas adotadas eram inovadoras para a época e abrangiam atuações nos meios de comunicação (rádio e televisão) e dentro da loja. O principal nome ligado ao lançamento das duas empresas é o de Raul Borges, considerado o "pai” dos supermercados no Brasil (Abras, 1993).

Os primeiros supermercados foram instalados nas áreas centrais das grandes cidades de forma a atender consumidores localizados em regiões densamente povoadas e de maior poder aquisitivo. As primeiras lojas ofereciam bens de alta qualidade e preços, incluindo produtos in natura. Apesar da vantagem das economias de escala que os supermercados possuíam em relação ao varejista tradicional, barreiras de entrada inibiram a rápida expansão das lojas de auto-serviço até o início da década de 60 (Cyrillo,1987):

- Barreiras de ordem legal: os supermercados foram reconhecidos apenas em 1968, o que gerava incertezas para investimentos na atividade durante o período de seu surgimento;

- Hábitos de compras: os consumidores preferiam o varejo tradicional, com atendimento personalizado em balcão;

- Custos: os armazéns tradicionais, empresas familiares, apresentavam vantagens de custo por abrigar no mesmo imóvel a loja e a moradia de seu proprietário e as feiraslivres não incorriam em custos com aluguéis;

- Sonegação: a principal fonte de receita para os estados na época era o Imposto sobre Vendas e Consignações (IVC), cujas altas alíquotas estimulavam a sonegação pelo varejo tradicional. Porém, os supermercados não se beneficiavam deste fator, pois 
como a estrutura administrativa é diferente, os funcionários fazem o registro mecânico das compras tornando a sonegação uma atividade difícil.

- Isenções: as cooperativas de consumo se beneficiavam de isenções de impostos não estendidas aos supermercados em geral;

- Linhas de crédito: devido aos riscos em que incorria a atividade e a concorrência com o varejo tradicional predominante, o mercado financeiro não oferecia linhas de crédito especiais para a atividade;

- Altas taxas de inflação: as taxas de inflação crescentes no final da década de 50 e início de 60 dificultavam a fixação dos preços nos supermercados, em benefício do atendimento em balcão pois o funcionário pode variar os preços mais facilmente.

As barreiras citadas trouxeram como principal conseqüência a operação ineficiente das lojas de auto-serviço, pois estas possuíam tamanho menor que a escala ótima e menor giro de mercadorias, o qual seria capaz de gerar grandes volumes de compra que poderiam promover maior poder de barganha das empresas junto aos fornecedores. Portanto, houve inicialmente desinteresse de empresários do varejo em adotar o novo sistema de auto-serviço (Cyrillo,1987).

A situação estabelecida devido aos problemas iniciais ao desenvolvimento do setor supermercadista no país permaneceu até o ano de 1964, quando a mudança de regime trouxe modificações fundamentais para diminuir as barreiras de entrada (Cyrillo,1987). Um exemplo das dificuldades de expansão do setor foi o Supermercado Sirva-se, que permaneceu todo o período com apenas duas lojas, sendo adquirido pela empresa Pão de Açúcar em 1965, a qual lançou seu primeiro supermercado em 1959 e se originou de uma doceria inaugurada onze anos antes (Abras, 1993).

\subsubsection{5-74 Rápida Expansão do Setor Supermercadista}

Durante a década de 1960 o problema do abastecimento urbano agravou-se, tornou-se fundamental a instituição de um sistema de armazéns e silos que possibilitasse diminuir a influência de intermediários que dificultavam o fluxo e aumentavam os custos da distribuição. Neste período foram introduzidas as organizações de centros de abastecimento estaduais, amenizando o problema de circulação de mercadorias 
(Abras, 1993). Até o final da década de 1960, apesar do desenvolvimento relativo das modernas formas de comercialização no sudeste e sul do país, a distribuição de alimentos nos bairros periféricos das grandes cidades e em outras regiões do país era dominada pelo varejo tradicional, principalmente as feiras-livres (Abras, 1993).

A mudança de regime em 1964 inicialmente trouxe a política antiinflacionária desenvolvida por Castelo Branco, 1964-1967, estabelecendo rígido controle sobre os salários, o déficit público e o crédito; observou-se o fechamento de diversas pequenas empresas e fusões e aquisições entre as maiores firmas, incluindo a indústria e o varejo de alimentos (Abras, 1993). Porém, o novo regime trouxe também benefícios ao setor supermercadista, diminuindo as dificuldades enfrentadas pelo setor para seu rápido desenvolvimento (Cyrillo, 1987).

Inicialmente, houve um esforço por parte do governo e sua fiscalização no combate à sonegação, diminuindo as diferenças relativas de preços promovidas por esta, principalmente entre o varejo especializado (tradicional) e os supermercados. Porém, foi em 1967 que o problema foi definitivamente resolvido com a substituição do Imposto sobre Vendas e Consignações (IVC) pelo Imposto sobre Circulação de Mercadorias (ICM), o qual mudava a concepção de um imposto sobre o valor da mercadoria para um imposto sobre o valor adicionado de cada etapa da comercialização, o que tornou a sonegação menos compensadora. Outra modificação importante que trazia o novo imposto era a eliminação da incidência sobre transferências dentro de uma mesma empresa, beneficiando as empresas de auto-serviço multilojas com centrais de compra (Cyrillo,1987 e Abras, 1993).

A simpatia do novo regime iniciado em 1964 com o setor supermercadista vinha do fato deste equipamento ser considerado mais moderno e da crença da existência de economias de escala das redes de supermercados, sendo que seu desenvolvimento seria importante para a modernização da comercialização e controle da inflação, cujas altas taxas preocupavam o país (Cyrillo, 1987). Portanto, o governo estimulou a regulamentação da atividade em 13 de novembro de 1968 com a Lei n 7.208, o que diminuiu as incertezas quanto ao futuro dos investimentos em novas lojas (Abras, 1993). 
Apesar das medidas governamentais tomadas após 1964 a estagnação econômica perdurou até 1967, sendo que apenas a partir do ano seguinte as políticas públicas, que incluíam o controle da inflação, modernização dos mercados de capitais e atração do capital estrangeiro, surtiram efeito e aumentaram a credibilidade do novo governo junto aos investidores nacionais e estrangeiros. Entre 1968 e 1974, época do denominado "milagre econômico", verificaram-se altas taxas de crescimento do Produto Interno Bruto, média de 11,3\% ao ano, situação oposta ao período imediatamente anterior (1962/67) em que a taxa média foi de 3,7\% ao ano (Baer, 1996).

A partir da década de 1970 ocorreu maior aproximação entre supermercadistas e governo fazendo com que o I Plano Nacional de Desenvolvimento (1972-1974) incorpora-se entre suas metas a expansão das redes de supermercados e outros sistemas de auto-serviço. A medida objetivava modernizar a distribuição de alimentos (Abras, 1993). Já em 1971 o governo, baseando-se no Programa de Modernização e Reorganização da Comercialização, destinou através da Caixa Econômica Federal uma linha especial de financiamento para o setor, a qual utilizava recursos do Banco Nacional de Desenvolvimento Econômico (BNDE) e do PIS. Porém, devido às exigências do programa de crédito, apenas grandes empresas foram beneficiadas pois de acordo com as regras estabelecidas a empresa financiada deveria possuir no mínimo seis lojas ou faturar acima de $\mathrm{Cr} \$ 24$ milhões anuais, o que restringiu o número de empresas potenciais para adquirir o financiamento (Cyrillo,1987).

Os resultados da diminuição das barreiras ao desenvolvimento do setor surgiram rapidamente, pois o número de lojas de auto-serviço e sua participação no faturamento total do varejo aumentaram substancialmente entre 1965 e 1970. Em 1966 haviam 992 supermercados no Brasil, dez anos depois, o número aumentou para 7.823 lojas (Abras, 1993). Durante o período, o formato de loja que mais se desenvolveu foi o hipermercado, o qual apresentava economias de escala devido ao seu maior tamanho e oferecia uma grande variedade de produtos, pois o tempo de compra do consumidor passava a se tornar cada vez mais escasso. Além disso, as lojas passavam a dividir o mesmo espaço com agências bancárias, cabeleireiros, chaveiros e outros estabelecimentos com o objetivo de aumentar o fluxo de pessoas na loja. Outras 
características das novas lojas eram o estacionamento próprio, funcionários que levavam as compras até o carro e música ambiente dentro da área de vendas de forma a atrair clientes (Cyrillo, 1987).

O primeiro hipermercado foi instalado em São José dos Campos no ano de 1971 pela empresa Peg-Pag, seguiram-se outros construídos por empresas nacionais, normalmente grandes redes devido ao alto investimento necessário. No entanto, em 1975 a empresa francesa Carrefour inauguraria sua primeira loja na cidade de São Paulo e o impacto das inovações administrativas trazidas por esta firma seria sentido apenas anos mais tarde. Cada hipermercado Carrefour era uma unidade autônoma, que gerenciava seus estoques, realizava negociações e determinava a variedade de produtos em sua área de vendas. Este sistema administrativo era oposto ao tradicional das redes de supermercados, com gerência centralizada, a gestão destas seria modificada apenas no final da década de 1980, período no qual as grandes redes reestruturariam toda a administração (Abras, 1993).

A situação social, urbana e econômica brasileira condicionaria a atuação dos supermercados como uma forma de comercialização de alimentos para a classe média, sendo que a periferia das cidades apenas seria atingida pelas grandes redes a partir da segunda metade da década de 1970 (Abras, 1993).

\subsubsection{5-85 Desaceleração do crescimento}

Após o "milagre econômico" no início dos anos 1970, o setor supermercadista passou a dominar o varejo no Brasil, pois já em 1975 os supermercados representavam aproximadamente $1 \%$ do número de lojas e 36\% da receita total (Abras, 1993). O país enfrentaria problemas econômicos a partir de novembro de 1973 (Choque do Petróleo), quando os preços do petróleo quadruplicaram no mercado internacional e o governo decidiu pagar os custos adicionais do uso da energia proveniente do petróleo importado por meio da manutenção de altas taxas de crescimento do PIB, a qual foi financiada com poupança externa. Portanto, o governo considerava que o valor adicional do custo do petróleo seria pago pelo aumento da renda gerada pelo crescimento da economia brasileira nos próximos anos, este aumento do Produto Interno Bruto foi possível graças 
à financiamento externo. A dívida externa do Brasil cresceu substancialmente desde 1973, estimulando ações do governo na substituição de importações e investimentos em infra-estrutura (Baer, 1996).

O segundo choque do petróleo (1979) obrigou o governo a cortar os subsídios à exportação e desvalorizar a moeda como medida compensatória para os exportadores, em 1981 o PIB caiu 1,6\% e o setor industrial 5,5\%. Nos anos seguintes o programa de austeridade prosseguiu de acordo com as regras do Fundo Monetário Internacional (FMI), medidas para a contenção da demanda foram tomadas como reajustes das tarifas públicas, aumento da taxa de juros e diminuição dos dos gastos públicos e investimentos das empresas estatais (Baer, 1996). Portanto, o período foi marcado por uma diminuição das taxas de crescimento econômico do país, fator que se refletiu em diminuição do crescimento em número de lojas e faturamento dos supermercados (Cyrillo,1987). A recessão também trouxe altas taxas de inflação, alcançando seu maior valor em 1984, o que teve influência maléfica sobre a distribuição de renda. Os consumidores, preocupados em controlar seus gastos, diminuíram o consumo de produtos supérfluos e davam preferência a bens de primeira necessidade, assim como optavam por marcas ou produtos similares de menor preço (Abras, 1993).

Frente à diminuição do consumo, as grandes empresas seguiram sua expansão adotando como estratégias de crescimento as fusões e aquisições e a busca de novos mercados. As maiores redes, antes com atuação restrita em seus estados de origem, passaram a abrir lojas e comprar empresas em diferentes regiões do país. A tendência foi mais forte no estado de São Paulo, onde a maior empresa do setor passou a adquirir firmas atuantes no próprio estado e mesmo nas regiões nordeste e sul, levando o processo de concentração até locais não atendidos pelas grandes redes (Cyrillo,1987).

A diminuição do crescimento da economia estimulou as empresas supermercadistas a abrir estabelecimentos de um diferente formato: as lojas de sortimento limitado. Estas apresentavam menor número de alimentos perecíveis e limitações de marcas e produtos, aproximando-se do formato original que surgiu em outros países em meio à recessão econômica por que passavam. A indústria de alimentos se posicionou contra as lojas de sortimento limitado devido à ausência de produtos 
sofisticados e menor número de marcas, fontes de poder de negociação dos fornecedores junto às empresas varejistas (Cyrillo,1987).

As lojas de sortimento limitado foram introduzidas normalmente por empresas já atuantes no setor, principalmente as maiores redes, passando a concorrer fortemente com os supermercados convencionais pois possuíam preços menores. O aumento do número de lojas mais simples atendia a vários objetivos das maiores empresas (Cyrillo,1987):

- Aumento do volume comercializado e conseqüente aumento do poder de negociação junto aos fornecedores;

- Atendimento de populações anteriormente excluídas do mercado de consumo com o objetivo de fixar a marca do varejista e posteriormente transformar a loja de sortimento limitado em supermercado convencional, adaptando os gostos e preferências dos consumidores para se tornarem clientes de maior fidelidade;

- Concorrer no mercado com lojas melhor adaptadas ao poder aquisitivo do consumidor e à situação econômica pela qual passava o país.

Apesar da diminuição do ritmo de crescimento da economia, os supermercados não foram fortemente afetados pela restrição da demanda, principalmente as maiores empresas do setor. A adaptação do mix de produtos e abertura de novas lojas com diferentes formatos (lojas de sortimento limitado) permitiram o aumento da receita total mesmo nos anos de maiores dificuldades, porém, com diminuição do faturamento por loja pois estas se tornaram menores e menos sofisticadas (Cyrillo,1987).

\subsubsection{6-94 Adaptação à crise econômica}

O governo do presidente Sarney (1985/90), primeiro civil a assumir o posto após o fim do regime militar, adotou novas políticas salariais e estimulou as exportações e a economia apresentou no ano de 1985 8,3\% de crescimento do PIB (Baer, 1996). Porém, o período foi caracterizado por recessão econômica, altas taxas de inflação e perda do poder de compra da população. Diversos planos de estabilização econômica foram elaborados, sendo que o setor supermercadista apoiaria todos eles, representado pela Associação Brasileira de Supermercados. Algumas grandes redes enfrentariam 
problemas financeiros, encerrando suas atividades ou sendo adquiridas por outras empresas (Abras, 1993).

Em resposta às variações no ambiente competitivo ocorridas neste período, como pressão de fornecedores e menores lucros, o setor supermercadista acelerou a abertura de lojas de sortimento limitado e supermercados mais simples, diminuindo custos com a compra, armazenamento, distribuição dos produtos e propaganda. Ao mesmo tempo, os investimentos em hipermercados diminuíram. O resultado da crise econômica brasileira foi o menor crescimento dos supermercados em faturamento, número de funcionários, área de vendas e número de lojas (Cyrillo, 1987).

No início de 1992, o setor apresentava uma significativa redução do faturamento total em comparação aos valores de dois anos anteriores (Abras, 1993). Porém, deve-se salientar que as maiores empresas do setor sofreram muito menos que as menores, pois as primeiras conseguiram se proteger mais eficientemente da inflação, assim como expandiram suas áreas de atuação através das estratégias mencionadas e utilização do mercado financeiro. Portanto, o crescimento das maiores empresas neste período foi maior que o do setor como um todo, aumentando a concentração (Cyrillo,1987).

A partir do final da década de 1980, o setor passou a modificar a gestão dos negócios, preocupando-se cada vez mais com o treinamento dos funcionários e adoção de ferramentas administrativas utilizando a informática. Neste período foi introduzido o código de barras, cuja adoção seria lenta pois exigiria adaptações da indústria e comércio. Além disso, a reestruturação administrativa das maiores firmas significou o fechamento de pequenas lojas com menor retorno e aumento dos gastos com propaganda, a fim de diminuir o impacto negativo dos períodos de congelamento de preços sobre a imagem das redes, que eram apontadas como responsáveis pela rápida remarcação de preços (Abras, 1993). 


\subsubsection{5 - Modernização do setor supermercadista}

$\mathrm{O}$ texto a seguir tem como principal objetivo a descrição e compreensão das causas e conseqüências das principais transformações ocorridas no setor supermercadista na década de 90, especialmente após o Plano Real implementado em 1994.

\subsubsection{Definição do setor supermercadista}

A definição da indústria/setor que é foco do estudo é importante para a análise dos resultados. Para a presente pesquisa, trata-se de determinar quais os tipos de estabelecimentos comerciais pertencem ao conjunto denominado setor supermercadista, o qual apresenta diversos formatos (tipos) de lojas. As empresas atuantes no país são classificadas de acordo com a Tabela 1, que foi estabelecida pela Associação Brasileira de Supermercados.

As principais características das lojas pertencentes ao setor são o autoatendimento e a possibilidade de compra dos produtos em unidades, diferenciando-se principalmente pelo tamanho, número de itens ofertados e sua natureza (alimentos e nãoalimentos). As firmas são classificadas como cadeias (redes) quando possuem número de lojas igual ou superior a seis e independentes quando menor ou igual a cinco. A área de vendas é aquela compreendida entre o início dos caixas e o último produto exposto.

No Brasil, a maior parte das lojas pertence aos formatos supermercado convencional e hipermercado e durante a década de 1990 houve uma tendência de transformação de lojas de menos de um caixa, com pouca sofisticação, para supermercados compactos incorporando novas seções como frios e laticínios, hortifrúti, padaria e açougue (SuperHiper, maio de 2001). 
Tabela 1. Classificação de lojas do setor supermercadista segundo a Associação Brasileira de Supermercados (ABRAS).

\begin{tabular}{|c|c|c|c|c|c|}
\hline $\begin{array}{c}\text { Formato } \\
\text { de loja }\end{array}$ & $\begin{array}{c}\text { Área de } \\
\text { vendas }\left(\mathrm{m}^{2}\right)\end{array}$ & $\begin{array}{l}\mathrm{N}^{\circ} \text { médio } \\
\text { de itens }\end{array}$ & $\begin{array}{l}\% \text { de vendas } \\
\text { não alimentos }\end{array}$ & $\begin{array}{l}\text { Número de } \\
\text { caixas }\end{array}$ & Seções \\
\hline $\begin{array}{c}\text { Loja de } \\
\text { Conveniência }\end{array}$ & $50-250$ & 1.000 & 3 & $1-2$ & $\begin{array}{c}\text { Mercearia, frios e laticínios, } \\
\text { bazar, snacks }\end{array}$ \\
\hline $\begin{array}{l}\text { Loja de } \\
\text { Sortimento } \\
\text { limitado }\end{array}$ & $200-400$ & 700 & 3 & $2-4$ & $\begin{array}{l}\text { Mercearia, hortifrúti, frios e } \\
\text { laticínios, bazar }\end{array}$ \\
\hline $\begin{array}{l}\text { Supermercado } \\
\text { compacto }\end{array}$ & $300-700$ & 4.000 & 3 & $2-6$ & $\begin{array}{l}\text { Mercearia, hortifrúti, carnes e } \\
\text { aves, frios e laticínios, bazar }\end{array}$ \\
\hline $\begin{array}{l}\text { Supermercado } \\
\text { convencional }\end{array}$ & $700-2.500$ & 9.000 & 6 & $7-20$ & $\begin{array}{l}\text { Mercearia, hortifrúti, bazar, } \\
\text { carnes e aves, peixaria, } \\
\text { padaria, frios e laticínios }\end{array}$ \\
\hline Superloja & $3.000-5.000$ & 14.000 & 12 & $25-36$ & $\begin{array}{l}\text { Mercearia, hortifrúti, bazar, } \\
\text { carnes e aves, peixaria, } \\
\text { padaria, frios e laticínios, } \\
\text { têxtil e eletrônicos }\end{array}$ \\
\hline Hipermercado & $7.000-16.000$ & 45.000 & 30 & $55-90$ & $\begin{array}{l}\text { Mercearia, hortifrúti, carnes e } \\
\text { aves, padaria, frios e } \\
\text { laticínios, bazar, peixaria, } \\
\text { têxtil, eletrônicos }\end{array}$ \\
\hline $\begin{array}{l}\text { Loja de } \\
\text { depósito }\end{array}$ & $4.000-7.000$ & 7.000 & 8 & $30-50$ & $\begin{array}{l}\text { Mercearia, hortifrúti, carnes e } \\
\text { aves, têxtil, frios e laticínios, } \\
\text { bazar e eletrônicos }\end{array}$ \\
\hline $\begin{array}{l}\text { Clube } \\
\text { atacadista }\end{array}$ & $5.000-12.000$ & 5.000 & 35 & $25-35$ & $\begin{array}{l}\text { Mercearia, bazar, carnes e } \\
\text { aves, têxtil, frios e laticínios e } \\
\text { eletrônicos }\end{array}$ \\
\hline
\end{tabular}

Fonte: Brito (1998)

\subsubsection{Estabilização econômica e comportamento do consumidor}

O fim da década de 1980 e início de 1990 foram marcados por um período de altas taxas de inflação no Brasil, o que teve um efeito maléfico sobre a distribuição de renda e afetou profundamente o comportamento das pessoas em relação ao consumo de alimentos. Em períodos de alta inflação, os agentes mais prejudicados são os indivíduos da classe mais baixa, os quais não conseguem proteger sua renda da rápida desvalorização da moeda, pagando um imposto inflacionário sobre os valores mantidos 
em seu bolso ou em contas bancárias sem correção monetária.

As altas taxas de inflação influenciavam o comportamento dos consumidores, as famílias se programavam para realizar suas compras imediatamente após o recebimento do salário e era comum fazer uma grande compra mensal de alimentos, pois postergá-la significava adquirir menos produtos para um mesmo valor monetário. O consumidor, preocupado em adquirir a maior quantidade de alimentos em menor tempo possível, buscava lojas que oferecessem todos os itens de que necessitava. A comparação entre os preços de um mesmo produto em várias lojas era dificultada pela grande velocidade de remarcações, fazendo com que as pessoas permanecessem sem referência de preços para a maior parte dos produtos, inclusive os da cesta básica (Supermercado Moderno, 1995).

Após a implementação do Plano Real em 1994, a estabilização econômica promoveu uma mudança do comportamento de compra das pessoas e um ganho real de renda proporcionado pela diminuição do imposto inflacionário, tornando possível realizar diversas compras ao longo do mês sem substancial perda do valor real do salário. Além disso, os preços estáveis permitiram ao consumidor a comparação destes nos diversos estabelecimentos comerciais e tempo suficiente para memorizá-los. A possibilidade de comparações de preços e maior tempo para as compras, melhor distribuídas ao longo do mês de acordo com a necessidade de cada família, promoveu o aumento das compras por impulso, exigência por qualidade e preços baixos (Sesso Filho, 2001b).

Bertasso (2000) utilizou dados da Pesquisa de Orçamentos Familiares (POF) do Instituto Brasileiro de Geografia e Estatística (IBGE) para analisar o comportamento do consumo de alimentos da população nos anos de 95/96 nas metrópoles brasileiras: Rio de Janeiro, Belo Horizonte, São Paulo, Porto Alegre, Curitiba, Fortaleza, Recife, Belém, Salvador, Goiânia e Brasília (DF). A autora classificou as famílias participantes da pesquisa como mostrado na Tabela 2 observa-se a maior participação das famílias tradicionais, seguidas pelas novas famílias. Os domicílios unitários, que representam $8,5 \%$ das famílias, constituem um importante indicador que os alimentos consumidos fora do domicílio e os de fácil preparo têm um grande público nas metrópoles, assim como a existência de novas famílias, constituídas por apenas uma pessoa de referência e 
que, portanto tem menos tempo para oferecer à sua família uma alimentação mais "tradicional".

Tabela 2. Classificação das famílias das principais metrópoles brasileiras em 1995/96.

\begin{tabular}{lcc}
\hline Tipo de família & $\%$ das famílias & $\%$ das pessoas \\
\hline Famílias tradicionais & 68,4 & 75,3 \\
Novas famílias & 17,0 & 17,2 \\
Famílias complexas & 5,4 & 4,8 \\
Domicílios unitários & 8,5 & 2,3 \\
Outros domicílios & 0,7 & 0,4 \\
\hline
\end{tabular}

Fonte: Bertasso (2000)

- Famílias tradicionais: domicílios compostos pela pessoa de referência e seu cônjuge; com ou sem filhos, outros parentes e empregados (empregados domésticos e seus parentes); e sem não-parentes (agregados, pensionistas e conviventes);

- Novas famílias: domicílios compostos pela pessoa de referência e filhos, sem cônjuge; com ou sem outros parentes e empregados (e seus parentes); e sem nãoparentes;

- Famílias complexas: domicílios habitados pelos tipos familiares acima citados, incluindo obrigatoriamente a presença de não-parentes; ou a simples coabitação de parentes que não cônjuges ou filhos (com ou sem não-parentes ou empregados e seus parentes);

- Domicílios unitários: domicílios habitados somente pela pessoa de referência, com ou sem empregados (e seus parentes);

- Outros domicílios: categoria residual.

O estudo apresentado pela autora analisou os efeitos de algumas variáveis socioeconômicas sobre o consumo alimentar do brasileiro metropolitano, concluindo que a renda ainda era um forte condicionante do consumo alimentar da maioria da população analisada. Este fator ainda influencia positivamente a frequiência de compras dos produtos. As elasticidades-renda média do dispêndio calculadas foram altas para a maior parte dos produtos, portanto, aumentos na renda serão convertidos em percentual 
importante em consumo de alimentos. A renda condiciona ainda o tipo de alimentação considerada "moderna", ou seja, alimentos pré-prontos, alimentação fora do domicílio e outros produtos que fogem do padrão alimentar "tradicional" como cereais e leguminosas (arroz e feijão), que necessitam de maior tempo de preparo.

O tamanho das famílias analisadas afetou positivamente o desperdício de alimentos, a diminuição do número de membros pode causar aumento per capita da quantidade de produtos adquirida. A composição etária dos membros das famílias também afeta o comportamento destas, assim, quando aumenta a proporção de pessoas na faixa de 21 a 30 anos, existe a tendência de consumo de alimentos fora do domicílio, principalmente lanches, salgadinhos, sucos e similares em contraposição a refeições. Segundo Bertasso (2000), o envelhecimento da população deverá causar a convivência de ambos padrões alimentares "tradicional" e "moderno" de alimentação, isto é, os indivíduos não discriminarão entre um e outro.

Os resultados do estudo mostram que a composição da família afeta fortemente as decisões de alimentação; fatores como escolaridade, idade e número de membros devem ser levados em consideração quando as empresas realizam pesquisas de mercado. Assim como famílias com mulheres que trabalham e auferem renda e são chefes ou cônjuges propiciam uma alimentação mais "moderna" para seus membros, especialmente os de consumo rápido como lanches e sucos.

Um dos principais fatores a serem levados em consideração para prever o consumo de alimentos é a renda, a Tabela 3 apresenta os valores de renda per capita no Brasil na década de 1990, nota-se o maior crescimento desta nos anos de 1993/94 e um declínio nos anos 1998/99. Além disso, deve-se levar em conta também o efeito da diminuição do imposto inflacionário sobre a renda disponível dos indivíduos, que beneficiou a parcela mais pobre da população, principalmente no momento imediatamente após a implementação do Plano Real. O aumento súbito da renda da população mais pobre significou, na prática, um aumento no consumo de alimentos. A indústria de alimentos acumulou um crescimento de aproximadamente 32\% entre 1994 e 2000, conforme se pode observar na Tabela 4. 
Tabela 3. Produto Interno Bruto per capita do Brasil, 1990-2000.

\begin{tabular}{rrrrr}
\hline Ano & $\begin{array}{c}\text { População } \\
\text { residente } \\
(1.000 \text { hab. })\end{array}$ & $\begin{array}{c}\text { PIB per capita a } \\
\text { preços } \\
\text { correntes }\end{array}$ & $\begin{array}{c}\text { PIB per capita } \\
\text { a preços } \\
\text { de } 2000\end{array}$ & $\begin{array}{c}\text { Variação } \\
\text { real anual }(\%)\end{array}$ \\
\hline 1990 & 147.594 & 0,08 & 5794,57 & - \\
1991 & 149.926 & 0,4 & 5609,76 & $(-) 0,54$ \\
1992 & 152.227 & 4,21 & 5521,01 & $(-) 2,05$ \\
1993 & 154.513 & 91,24 & 5709,66 & 3,37 \\
1994 & 156.775 & $2.227,43$ & 5956,01 & 4,33 \\
1995 & 159.016 & $4.063,69$ & 6119,89 & 2,75 \\
1996 & 161.247 & $4.830,40$ & 6193,35 & 1,24 \\
1997 & 163.471 & $5.326,59$ & 6310,03 & 1,87 \\
1998 & 165.688 & $5.517,53$ & 6234,85 & $(-) 1,21$ \\
1999 & 167.910 & $5.740,39$ & 6200,78 & $(-) 0,52$ \\
2000 & 170.143 & $6.386,98$ & 6386,98 & 2,99 \\
\hline
\end{tabular}

Fonte: IBGE (2002)

Tabela 4. Desempenho da indústria de alimentos no Brasil entre 1996/2000.

\begin{tabular}{lccccc}
\hline Destino da produção/ano & 1996 & 1997 & 1998 & 1999 & 2000 \\
\hline Mercado interno & 64,5 & 78,7 & 85,8 & 92,3 & 100,2 \\
Exportação & 9,7 & 9,9 & 10,1 & 15,6 & 14,0 \\
\hline
\end{tabular}

Fonte: SuperHiper (2002)

Nota: valores constantes de 2000 em R \$ bilhões.

O aumento da demanda por alimentos pode ser explicado pela sua elasticidaderenda da despesa, conforme mostrada na Tabela 5, que apresenta também valores para outros conjuntos de produtos e serviços. Observa-se que para um aumento de renda $1 \%$, os gastos com alimentos aumentarão de $0,436 \%$, enquanto o aumento com gastos com vestuário será de $0,678 \%$. Portanto, a elasticidade-renda média de alimentos é menor do que as de outros produtos. No entanto, deve-se considerar que o aumento do poder de compra de classes mais baixas, isto é, uma melhor distribuição da renda nacional, ocasiona um maior aumento da despesa com alimentos quando se compara o efeito do mesmo aumento porcentual da renda para classes mais altas. Os itens educação e recreação e cultura apresentam os altos valores, próximos de um, indicando uma tendência de aumentos proporcionais destas despesas ao aumento da renda per capita. 
Tabela 5. Elasticidades-renda da despesa de produtos e serviços no Brasil em 1995/96.

\begin{tabular}{lccccc}
\hline \multirow{2}{*}{ Tipo de despesa } & Esquema de & \multicolumn{3}{c}{ Elasticidade no estrato } & Elasticidade \\
& agrupamento & I & II & III & Média \\
\hline Alimentação & $7-2-1$ & 0,398 & 0,811 & 0,190 & 0,436 \\
Habitação & $2-6-2$ & 0,353 & 0,768 & 0,697 & 0,714 \\
Vestuário & $2-6-2$ & 0,583 & 0,793 & 0,605 & 0,678 \\
Transporte & $6-2-2$ & 0,775 & 1,023 & 0,640 & 0,766 \\
Higiene e cuidados pessoais & $7-2-1$ & 0,595 & 0,835 & 0,145 & 0,530 \\
Assistência à saúde & $3-5-2$ & 0,198 & 1,023 & 0,623 & 0,734 \\
Educação & $5-3-2$ & 0,955 & 1,808 & 0,676 & 0,997 \\
Recreação e cultura & $2-3-5$ & 0,298 & 1,559 & 0,883 & 0,953 \\
Fumo & $3-2-5$ & 0,169 & 0,775 & 0,133 & 0,251 \\
Serviços pessoais & $3-4-3$ & 0,601 & 1,033 & 0,697 & 0,784 \\
Despesas diversas & $3-3-4$ & 0,599 & 1,425 & 0,977 & 1,008 \\
\hline
\end{tabular}

Fonte: Hoffmann (2000)

O esquema de agrupamento a que se refere a Tabela 5 é relativo ao número de classes de renda agrupados em cada estrato. A Tabela 6 apresenta as classes de renda e os dados gerais das famílias em cada estrato de renda. Portanto, para o item alimentos, o estrato I refere-se às sete classes mais baixas de renda, o estrato II agrupa as duas classes de renda intermediárias e o estrato III reúne informações sobre o grupo de consumidores de maior poder aquisitivo. Um aumento na renda média do estrato II causará um aumento de $0,811 \%$ nos gastos de alimentos para esse grupo de consumidores, enquanto esse mesmo aumento porcentual para o estrato III causará um aumento relativamente menor de $0,190 \%$.

A Tabela 7 apresenta detalhes da elasticidade-renda da despesa de alimentos no Brasil, é importante observar que a elasticidade-renda do consumo no domicílio é menor do que a metade da elasticidade-renda do consumo fora do domicílio e Alimentos preparados, o aumento de $1 \%$ da renda média causa, respectivamente, um aumento de $0,745 \%$ e $0,791 \%$ dos gastos com estes grupos de alimentos. Isto indica que os varejistas devem se preocupar em oferecer produtos pré-preparados e instalar pequenos restaurantes dentro de suas lojas, principalmente hipermercados. Caso contrário, perderão uma fatia do mercado para outros estabelecimentos. 
Tabela 6. Número de famílias, tamanho médio da família, recebimento mensal familiar e recebimento per capita nas 10 classes de recebimento mensal familiar para da Pesquisa de Orçamentos Familiares (POF).

\begin{tabular}{lrcrr}
\hline \multirow{2}{*}{$\begin{array}{l}\text { Classe } \\
\text { (salário mínimo) }\end{array}$} & $\begin{array}{c}\text { Número de } \\
\text { famílias } \\
(1.000)\end{array}$ & $\begin{array}{c}\text { Número médio } \\
\text { de pessoas por } \\
\text { família }\end{array}$ & \multicolumn{2}{c}{ Recebimento mensal (R\$) } \\
\cline { 4 - 5 } Até 2 & 1.305 & 2,96 & Por família & Per capita \\
Mais de 2 a 3 & 1.050 & 3,37 & 148,10 & 50,12 \\
Mais de 3 a 5 & 1.912 & 3,74 & 281,52 & 83,51 \\
Mais de 5 a 6 & 892 & 3,75 & 645,03 & 119,10 \\
Mais de 6 a 8 & 1.387 & 3,83 & 616,52 & 164,40 \\
Mais de 8 a 10 & 972 & 3,95 & 786,11 & 205,49 \\
Mais de 10 a 15 & 1.661 & 3,93 & $1.016,68$ & 257,60 \\
Mais de 15 a 20 & 964 & 3,96 & $1.381,28$ & 351,59 \\
Mais de 20 a 30 & 945 & 3,82 & $1.968,58$ & 496,50 \\
Mais de 30 & 1.456 & 3,71 & $2.760,58$ & 722,54 \\
\hline
\end{tabular}

Fonte: Hoffmann (2000)

Tabela 7. Elasticidade-renda da despesa de alimentos no Brasil em 1995/96.

\begin{tabular}{lccccc}
\hline \multirow{2}{*}{ Tipo de despesa } & Esquema de & \multicolumn{3}{c}{ Elasticidade no estrato } & Elasticidade \\
& agrupamento & I & II & III & Média \\
\hline Alimentação & $7-2-1$ & 0,398 & 0,811 & 0,190 & 0,436 \\
Alimentação no domicílio & $7-2-1$ & 0,303 & 0,827 & $-0,031$ & 0,344 \\
Alimentos preparados & $3-5-2$ & 0,050 & 1,341 & 0,527 & 0,791 \\
Alimentação fora do domicílio & $1-6-3$ & 0,471 & 0,852 & 0,683 & 0,745 \\
\hline
\end{tabular}

Fonte: Hoffmann (2000)

Os aumentos sucessivos da renda per capita dos brasileiros ocasionaram, principalmente nos dois anos posteriores à estabilização da economia, não apenas um aumento na quantidade consumida dos alimentos, mas também uma modificação na característica da demanda devido às diferentes elasticidades-renda dos produtos, como pode ser observado na Tabela 8. Produtos tradicionais, como arroz e feijão, possuem valores de elasticidade-renda da demanda próximos de zero ou negativos, tornando o consumo estagnado ou diminuindo-o com acréscimos na renda dos consumidores. Por outro lado, itens como legumes, frutas e verduras apresentam altos valores, assim o aumento do poder de compra da população ocasiona um aumento substancial da quantidade demandada desses produtos. 
Tabela 8. Elasticidade-renda do consumo físico de alimentos no Brasil em 1995/96.

\begin{tabular}{lccccc}
\hline \multirow{2}{*}{ Alimento } & Esquema de & \multicolumn{3}{c}{ Elasticidade no estrato } & Elasticidade \\
& agrupamento & I & II & III & Média \\
\hline Farinha de mandioca & $2-5-3$ & 0,117 & $-0,721$ & $-0,103$ & $-0,400$ \\
Feijão & $3-4-3$ & 0,213 & $-0,476$ & 0,194 & $-0,070$ \\
Arroz polido & $3-2-5$ & 0,510 & $-0,782$ & 0,005 & $-0,005$ \\
Óleo de soja & $3-2-5$ & 0,544 & $-0,609$ & 0,022 & 0,052 \\
Carnes bovinas de segunda & $1-8-1$ & 1,069 & 0,058 & $-0,668$ & 0,055 \\
Pão francês & $1-8-1$ & 0,170 & 0,085 & $-0,113$ & 0,067 \\
Aguardente de cana & $7-2-1$ & 0,360 & $-3,080$ & 1,265 & 0,068 \\
Macarrão & $1-4-5$ & 1,208 & $-0,249$ & 0,232 & 0,099 \\
Café moído & $3-4-3$ & 0,304 & $-0,148$ & 0,288 & 0,118 \\
Farinha de trigo & $1-2-7$ & 1,988 & $-0,105$ & 0,082 & 0,123 \\
Leite de vaca pasteurizado & $2-6-2$ & 0,704 & 0,259 & 0,156 & 0,274 \\
Laranja & $7-1-2$ & 0,313 & 1,098 & 0,030 & 0,312 \\
Carnes bovinas de primeira & $1-8-1$ & 1,007 & 0,594 & $-0,233$ & 0,442 \\
Maçã & $5-4-1$ & 0,675 & 0,461 & 0,163 & 0,460 \\
Queijo minas & $7-2-1$ & 0,436 & 1,158 & 0,194 & 0,526 \\
Cerveja & $3-4-3$ & 0,582 & 1,084 & 0,313 & 0,619 \\
Queijo prato & $2-2-6$ & 1,368 & 0,301 & 0,706 & 0,689 \\
Queijo muzzarella & $3-2-5$ & 0,526 & 2,716 & 0,743 & 0,900 \\
Óleo de milho & $4-1-5$ & 0,632 & 5,491 & 0,430 & 0,997 \\
Óleo de oliva & $7-2-1$ & 0,890 & 2,971 & $-1,459$ & 1,026 \\
Filé e filé mignon & $1-4-5$ & 3,271 & 0,633 & 1,400 & 1,344 \\
\hline
\end{tabular}

Fonte: Hoffmann (2000)

Pode-se concluir, após analisar o consumo de alimentos no período, que a tendência na década de 1990, e que deve permanecer se a renda per capita continuar crescendo, é de substituição de alimentos tradicionais por outros com maior processamento e valor agregado ou frescos como frutas, verduras e sucos naturais, devido a seu apelo saudável.

O aumento do consumo de alimentos e modificação das características da demanda, pois os consumidores passaram a preferir produtos com maior conveniência, tornaram o ambiente propício para a entrada de novas empresas e crescimento das firmas já atuantes do setor supermercadista. O mercado brasileiro tornou-se interessante para empresas varejistas cujos países de origem apresentavam consumo de alimentos praticamente estagnado e de competição acirrada, como a Europa e os Estados Unidos (Santos \& Gimenez, 2001). 
Um dos desafios para as empresas supermercadistas no final dos anos 1990 é adequar o mix de produtos das lojas, principalmente para redes que atuam em diferentes regiões, com populações de gostos e preferências heterogêneas. Além disso, formatar as lojas de acordo com cada localidade, adaptando-se rapidamente ao mercado (Saab et al., 2000a).

\subsubsection{Lançamentos de novos produtos}

A indústria de alimentos rapidamente reagiu às variações no consumo analisadas anteriormente, tornando-se preocupada em atender aos anseios dos consumidores sem perder atenção sobre as vendas e margens de comercialização, esta passou a intensificar os lançamentos de novos produtos. A Figura 1 ilustra o número de lançamentos de alimentos no período 1997/2001, no qual houve um aumento de aproximadamente 50\% do número de novos itens. A Figura 2 mostra que em algumas categorias de produtos, como salgadinhos e refrigerantes, o número de novos itens pode chegar a mais de mil em um ano.

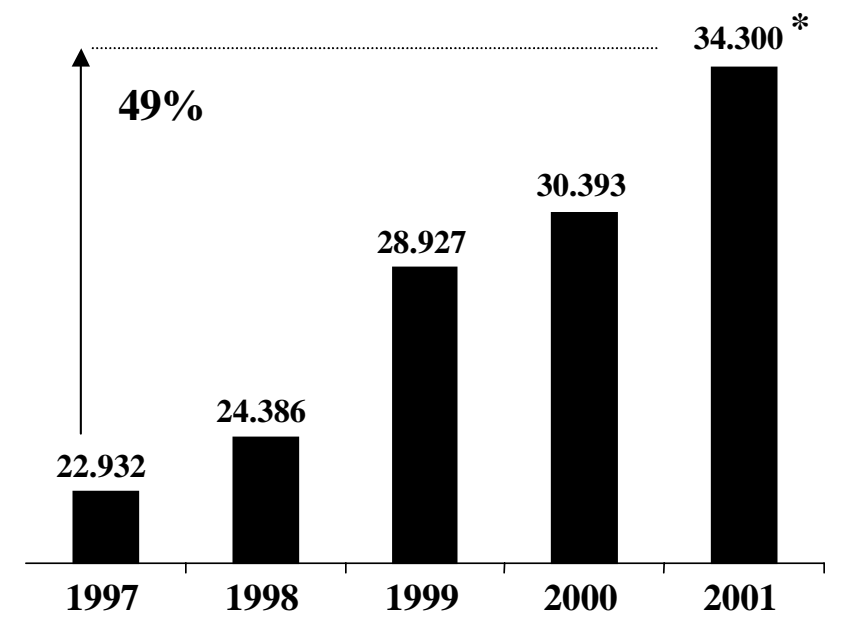

Figura 1 - Lançamentos de novos produtos no Brasil no período 1997/2001.

Fonte: Consultoria ACNielsen (2002) ${ }^{1}$

\footnotetext{
${ }^{1}$ CONSULTORIA ACNIELSEN. Panorama do gerenciamento por categorias no Brasil. Apresentação
} no II Prêmio ECR de Pesquisa para a Associação Brasileira de Supermercados. São Paulo, 2002. 


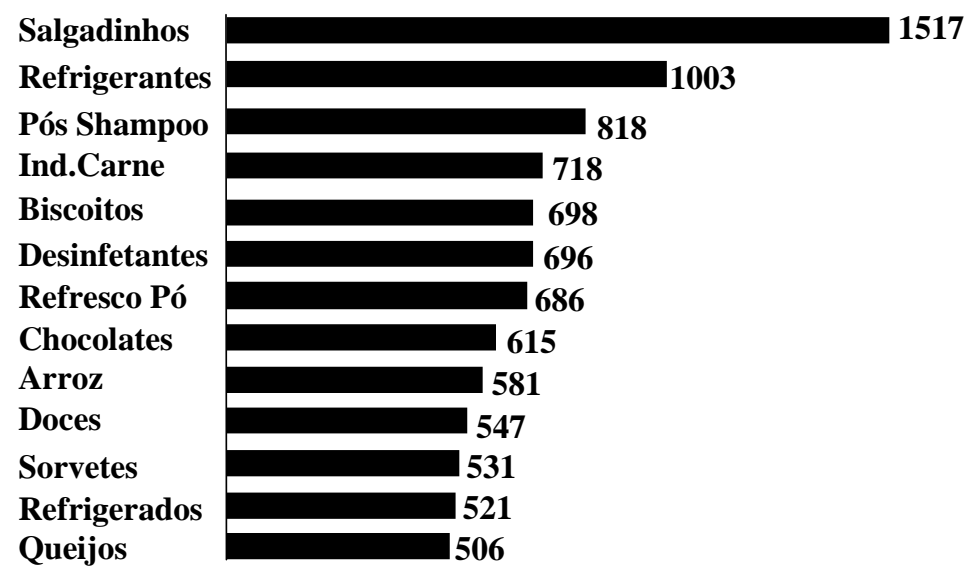

Figura 2 - Lançamentos de novos produtos no Brasil em algumas categorias de produtos no ano de 2001.

Fonte: Consultoria ACNielsen (2002) ${ }^{2}$

Atualmente, o número de novos produtos e a velocidade em que surgem é suficiente para que a indústria enfrente sérias limitações com relação ao espaço nas prateleiras dos supermercados. Outra conseqüência do rápido lançamento de novos produtos foi a diminuição do ciclo de vida da maior parte deles sendo mais rapidamente substituídos por outros. A tendência atinge também a comercialização de produtos in natura, com o desenvolvimento de variedades com diferentes colorações, diversas combinações de minimamente processados e tipos miniaturizados (baby) (Fernandes \& Neves, 1997).

A indústria de alimentos ampliou o lançamento de novos produtos no intuito de aumentar vendas e lucros, no entanto, existe uma limitação física nos supermercados: o espaço nas prateleiras. Devido a este fato, a indústria promove seus lançamentos junto aos varejistas e chega mesmo a pagar prêmios para colocá-los em exposição. Outra consequiência da intensa introdução de novos produtos é a diminuição de seu ciclo de vida, pois são mais rapidamente substituídos por outros (Connor \& Schiek, 1997). A tendência de lançamentos de grande número de produtos está presente no Brasil, pois apareceram nos supermercados brasileiros 21,9 mil novos itens em 150 categorias de produtos apenas em 1997 (Supermercados, 1998).

${ }^{2}$ CONSULTORIA ACNIELSEN. Panorama do gerenciamento por categorias no Brasil. Apresentação no II Prêmio ECR de Pesquisa para a Associação Brasileira de Supermercados. São Paulo, 2002. 


\subsubsection{Entrada de Novas Empresas Varejistas}

As baixas barreiras à entrada em conjunto com um ambiente favorável ocasionaram entre os anos de 1996 e 2000 um aumento do número de lojas do setor supermercadista de cerca de $40 \%$. Os novos agentes participantes do mercado constituíam-se notadamente de pequenas empresas nacionais e grandes redes varejistas multinacionais. No período 1996/2000 foram abertos 17.496 novos pontos de venda, dos quais $78 \%$ pertenciam a pequenas empresas (Leme et. al, 2000). Concomitantemente à entrada de pequenas empresas, outras desapareceram devido à consolidação das maiores redes de supermercados, levando à concentração do setor quando se analisam as participações no faturamento bruto total. A legislação brasileira não impõe problemas à entrada de grandes grupos varejistas estrangeiros no mercado. Porém, existem algumas barreiras de entrada específicas da própria atividade e que são enfrentadas por todos os entrantes:

- Fidelidade do consumidor, que está relacionada à reputação da loja;

- Menor conhecimento do mercado por parte da empresa entrante em relação às que estão no mercado;

- Realização de contratos com fornecedores, devido ao desconhecimento das peculiaridades do mercado;

- Escolha correta da localização da loja, fator importante na escolha da loja pelo consumidor;

- Economias de escala, obtidas, entre outras formas, pela centralização do abastecimento das lojas em um único centro de distribuição ou depósito, o que somente pode ser obtida com um número de lojas que viabilizem a manutenção dessa estrutura; e

- Retaliação por parte dos competidores instalados, que podem praticar preços inferiores aos praticados antes da entrada do novo competidor, ou ainda realizações de promoções (Leme \& Teixeira, 2000). 
As barreiras de entrada podem ser contornadas por meio da aquisição de firmas atuantes no mercado alvo. A aquisição possibilita adquirir a fidelidade do consumidor, o conhecimento do mercado através dos antigos funcionários, as relações com os fornecedores e outras vantagens quando comparada à entrada no mercado com a abertura de novas lojas. A estratégia é comumente utilizada por grandes redes para expandir sua área de atuação.

As barreiras à saída da atividade são pequenas, as quais constituem-se principalmente por custos irrecuperáveis (sunk costs), que são gastos na implantação da empresa e não resgatáveis em um possível fechamento. No caso de uma empresa varejista, os custos de saída são considerados pequenos em relação a outras atividades por existir um mercado de aluguéis para os bens de capital utilizados na atividade (Leme $\&$ Teixeira, 2000).

Kumar (1997) aponta como principais fatores que estimularam a atuação de grupos varejistas em diversos mercados: baixo crescimento dos mercados domésticos das empresas, formatos de lojas sofisticados com potencial para serem implantados em diversos países, disponibilidade de tecnologia que permite o controle das operações de lojas distantes entre si, padrões globais de consumo e a abertura de novos mercados com setor varejista subdesenvolvido. De fato, pode-se verificar que as afirmações feitas pelo autor se encaixam no modelo brasileiro, assim como para as empresas que passaram a atuar no mercado nacional na década de 1990. Muitas empresas adquiridas por grupos estrangeiros possuíam ativos subavaliados devido à defasagem tecnológica, havendo vantagem em sua aquisição e permitindo a entrada dos novos agentes.

Nos anos 1990 grandes empresas varejistas se instalaram no Brasil e no final da década constituíam os maiores grupos do setor no país, conforme se pode observar na Tabela 9. No final da década de 1980, o grupo português Sonae iniciou suas atividades no país através de uma joint venture com a rede Josepar, criando a Cia Real de Distribuição (CRD). Após adquirir a totalidade da CRD, o grupo comprou o supermercado Cândia Distribuição Brasil S.A. dando origem ao Sonae Distribuição do Brasil S.A. (Silva \& Famá, 1999). 
O grupo holandês Royal Ahold iniciou suas atividades no Brasil adquirindo 50\% do capital do Supermercado Bompreço em 1996, assumindo o controle integral da rede em junho de 2000. O grupo francês Casino ingressou no mercado brasileiro em 1999 adquirindo cerca de $22 \%$ das ações da Companhia Brasileira de Distribuição, controlada pelo grupo Pão de Açúcar S.A. Indústria e Comércio com 47\% das ações (Silva \& Famá, 1999). O norte-americano Wal-Mart realizou uma joint venture com as Lojas Americanas e inaugurou a primeira loja em 1995.

A rede Carrefour, que obteve o segundo maior faturamento do setor no ano 2000, está presente no mercado nacional desde 1974, atuando principalmente no segmento de hipermercados. Porém, devido às mudanças no ambiente competitivo ocorridas no país descritas anteriormente, começou a atuar no segmento de supermercados sob a bandeira Champion a partir do final da década de 1990 (Silva \& Famá, 1999).

Tabela 9. Nomes das empresas estrangeiras atuantes no país, país de origem, faturamento bruto e ano de entrada no mercado brasileiro.

\begin{tabular}{lccc}
\hline Empresa & $\begin{array}{c}\text { Faturamento } \\
\text { Bruto em 2000 } \\
\text { (R\$ milhões) }\end{array}$ & Origem do Capital & $\begin{array}{c}\text { Ano de } \\
\text { Entrada }\end{array}$ \\
\hline Companhia Brasileira de Distribuição (Casino) & 9.550 & Brasileiro/Francês & 1999 \\
Carrefour Com. Ind. Ltda & 9.520 & Francês & 1975 \\
Bompreço S/A Supermercados & 3.042 & Holandês & 1996 \\
Sonae Distribuição Brasil S/A & 2.478 & Português & 1989 \\
Wal-Mart Brasil Ltda & 1.211 & Norte Americano & 1995 \\
Jerônimo Martins/Sé Supermercados* & 934 & Português & 1997 \\
\hline
\end{tabular}

Fonte: SuperHiper (2001); SuperHiper (2002)

* empresa adquirida pela Companhia Brasileira de Distribuição (Grupo Pão de Açúcar) no ano de 2002.

No período entre 1970 e 1994, a expansão do setor ocorreu no segmento hipermercados. Porém, as dificuldades em encontrar terrenos em locais de fácil acesso e livres de concorrência estão favorecendo a abertura de lojas menores dentro das áreas urbanas e mais próximas dos consumidores (Leme et. al, 2000). 


\subsubsection{Novas Tecnologias}

No período de altas taxas de inflação os lucros dos supermercados eram em sua maior parte adquirida por meio de ganhos financeiros, pois compravam-se os produtos a prazo, os vendiam à vista, ganhando com a desvalorização da moeda, causada pela alta taxa de inflação, e com a aplicação do dinheiro no mercado financeiro. Com o fim da inflação, esses ganhos foram reduzidos e houve a necessidade de aprimorar a eficiência operacional, que havia sido negligenciada, com investimentos em novas tecnologias. Além disso, as margens de comercialização de todas as empresas foram ajustadas de forma a compensar a diminuição dos recebimentos do mercado financeiro, como mostra a Tabela 10.

Tabela 10. Modificação das margens de comercialização em supermercados antes e após a implementação do Plano Real (1994).

\begin{tabular}{lcc}
\hline \multirow{2}{*}{ Seções } & \multicolumn{2}{c}{ Margem-objetivo } \\
& Pré-Real & Pós-Real \\
\hline Mercearia alimentícia & $11,8 \%$ & $15,6 \%$ \\
Mercearia não alimentícia & $14,5 \%$ & $18,5 \%$ \\
Mercearia líquida & $15,4 \%$ & $17,8 \%$ \\
Perecíveis & $10,2 \%$ & $15,6 \%$ \\
Refrigerados/Congelados & $11,7 \%$ & $16,6 \%$ \\
Hortigrutigranjeiros & $13,0 \%$ & $19,5 \%$ \\
Padaria & $35,3 \%$ & $44,5 \%$ \\
Bazar/Eletrônicos & $24,8 \%$ & $30,8 \%$ \\
Têxtil/Magazine & $25,4 \%$ & $33,2 \%$ \\
Cesta básica ampliada & $4,9 \%$ & $8,0 \%$ \\
\hline
\end{tabular}

Fonte: Lepsch (1996)

Durante a década de 1990, o varejo iniciou um processo de automação, objetivando melhorar a eficiência e o controle operacional, o que envolve a recepção de produtos nas lojas, estoque de mercadorias, gerenciamento de categorias, departamento financeiro e os caixas (com leitores óticos). A adoção dessa tecnologia está transformando como os varejistas estão gerenciando as operações nas lojas, a conFiguração do fornecimento de mercadorias e a interação com os consumidores. 
Entre as inovações encontra-se a Resposta Eficiente ao Consumidor (Efficient Consumer Response - ECR). Esta é uma estratégia que busca estabelecer vínculos mais próximos entre o varejo, fornecedores e indústria, visando melhorar a eficiência na distribuição dos produtos e informações e proporcionar maior valor ao consumidor (Dib, 1997). A Transferência Eletrônica de Informações (Electronic Data Interchange - EDI), parte integrante da ECR, consiste na comunicação direta de dados entre computadores. Isto elimina a necessidade de redigitação de informações economizando o uso de mãode-obra, papel e tempo gastos entre o pedido e a entrega na loja dos produtos. Esse sistema reduz os erros de informação dos operadores e os custos, automatizando o fluxo de informações e permite, também, a modificação na forma da gestão do negócio devido a possibilidade de observação e mensuração mais complexa aproximando o relacionamento com os consumidores (Takaoka \& Navajas, 1997).

\section{- Automação comercial}

A automação das lojas é dividida basicamente em 2 partes:

1. Automação de frente (automação dos caixas), o que envolve o uso de leitores de código de barra e máquinas de preenchimento de cheque. Os objetivos são o atendimento mais rápido ao consumidor e a geração de informações sobre as vendas. A automação dos caixas reduz em cerca de $30 \%$ o tempo de atendimento ao cliente, diminuindo filas e possibilitando diminuir o número de caixas e utilizar parte da área destinada a estes para exposição de produtos.

2. Automação de retaguarda, cujo objetivo principal é analisar as informações geradas na loja e elaborar relatórios gerenciais (Automação, 1996).

A automação comercial no setor supermercadista brasileiro teve um grande impulso após 1995, como se pode observar na Figura 3. Inicialmente, as grandes redes investiram pesadamente em novos equipamentos, mas rapidamente as pequenas empresas passaram a utilizar as novas tecnologias principalmente os caixas automatizados para melhorar o atendimento dos clientes. Porém, a automação de retaguarda ainda é um fator limitante em várias empresas, prejudicando a utilização do 
grande fluxo de informações provenientes dos caixas e elaboração de relatórios gerenciais.

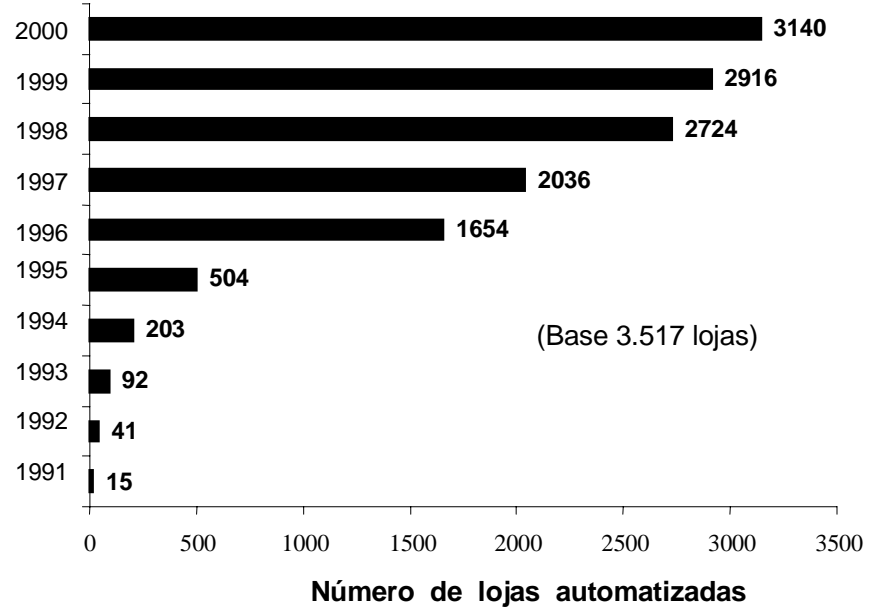

Figura 3 - Automação comercial no setor supermercadista brasileiro.

Fonte: SuperHiper (2001)

- Transferência eletrônica de informações - EDI (Electronic Data Interchange)

A transferência eletrônica de informações é basicamente comunicação computador-computador. No início, a vantagem de utilizar EDI para pedidos havia sido a redução de erros de informação dos operadores. Atualmente, atacadistas e varejistas usam o sistema para reduzir custos automatizando o fluxo de informação (Graham \& Nazem, 1996). O uso do sistema EDI permite economizar uso da mão-de-obra, reduzir uso de papel e o tempo dispendido do pedido à entrega dos produtos no sistema de distribuição (Connor \& Schiek, 1997).

\section{- Resposta eficiente ao consumidor - ECR (Efficient Consumer Response)}

A Resposta Eficiente ao Consumidor é uma iniciativa da indústria, envolvendo processadores, atacadistas e varejistas objetivando-se melhorar a eficiência na distribuição dos produtos (Connor \& Schiek, 1997). O ECR procura obter eficiência em 4 áreas: sortimento da loja, sistemas de reposição, promoções e introdução de novos produtos. 
O esforço para a realização do ECR abrange desde o uso de EDI até modificações nas embalagens e meios de transporte para tornar o movimento dos produtos ao longo do sistema mais rápido, proporcionando uma resposta mais rápida e eficiente às mudanças do consumo (Heijbroek et al., 1994). Algumas das vantagens do uso do ECR são: redução dos estoques de todo o sistema, promoções de produtos mais eficientes e introdução eficiente de produto. Para atacadistas e varejistas: melhor fluxo de caixa, maior eficiência dos estoques e redução dos custos administrativos. Para a indústria: maior eficiência da produção, melhor gerenciamento do inventário e melhor eficiência de promoção. Devido à natureza altamente competitiva do varejo de alimentos, espera-se que a diminuição dos custos seja repassada aos preços dos produtos aos consumidores (Connor \& Schiek, 1997).

A implementação do ECR é cara e seu retorno não é imediato, portanto, muitas empresas não implementam este sistema de forma completa apesar dos grandes benefícios estimados. Nos Estados Unidos, a ECR tem um potencial de reduzir os custos dos supermercados com inventário, requisição de produtos, fatura, e pagamento em 30 bilhões de dólares, e na Europa de 33 bilhões de dólares (Kumar, 1997).

\section{- As Novas Tecnologias e o Aumento da Produtividade}

As novas tecnologias ocasionaram um aumento de produtividade do setor, notadamente nos primeiros dois anos posteriores à implantação do Plano Real, pode-se explicar este aumento da produtividade através do aumento do consumo e automação comercial. A Tabela 11 mostra o aumento dos indicadores de desempenho durante a década de 1990, nota-se que o indicador faturamento real por funcionário não apresentou aumento de desempenho, comparando-o com os outros indicadores como funcionários por área de vendas, por loja e por caixa. Os valores indicam que houve uma diminuição da necessidade por mão-de-obra, porém, a produtividade do trabalho medida por faturamento por pessoa apresentou um decréscimo. 
Tabela 11. Dados gerais e indicadores de produtividade do trabalho no setor supermercadista.

\begin{tabular}{lrrrrrrrr}
\hline Indicadores de produtividade & \multicolumn{1}{c}{1994} & \multicolumn{1}{c}{1995} & 1996 & 1997 & 1998 & 1999 & 2000 & \multicolumn{2}{c}{2001} \\
\hline Lojas & 37.543 & 41.839 & 43.763 & 47.787 & 51.502 & 55.313 & 61.259 & 69.396 \\
Faturamento bruto* & 71,00 & 68,43 & 71,00 & 70,86 & 75,10 & 73,05 & 72,22 & 72,50 \\
Empregos & 650.000 & 655.200 & 625.000 & 655.000 & 666.752 & 670.086 & 701.622 & 710.743 \\
Área (milhões m²) & - & - & - & 12,00 & 12,70 & 13,10 & 14,30 & 15,30 \\
Caixas & - & - & - & 123.170 & 125.867 & 135.914 & 143.705 & 156.022 \\
Faturamento/funcionário** & 0,11 & 0,10 & 0,11 & 0,11 & 0,11 & 0,11 & 0,10 & 0,10 \\
Funcionários/loja & 17,31 & 15,66 & 14,28 & 13,71 & 12,95 & 12,11 & 11,45 & 10,24 \\
Funcionários/área*** & - & - & - & 54,58 & 52,50 & 51,15 & 49,06 & 46,45 \\
Funcionários/caixa & - & - & - & 5,32 & 5,30 & 4,93 & 4,88 & 4,56 \\
\hline
\end{tabular}

Fonte: SuperHiper (1974-)

* bilhões R\$ de 2001

** milhões $\mathrm{R} \$$ /pessoa (valores deflacionados para o ano 2001)

*** área em milhares de metros quadrados

nd = não disponível

Silva \& Famá (1999) afirmam que após o ganho de produtividade obtido por meio da utilização de novas tecnologias nos anos de 1995 e 1996, principalmente com o uso de caixas automatizados, as grandes empresas passaram a direcionar-se para os ganhos de economias de escala, ocasionando um processo de fusões e aquisições nos anos posteriores. No entanto, durante a década de 90 as redes de supermercados de menor porte passaram a se aproximar em termos de desempenho em vendas dos gigantes do setor por motivo das incorporações de empresas de porte médio e menos eficientes realizadas por firmas que tiveram grande crescimento através de fusões e aquisições, conforme comprovado por Sesso Filho (2001a). 


\subsubsection{Estratégias das Grandes Redes de Supermercados}

A entrada de grandes grupos varejistas estrangeiros no mercado brasileiro iniciou um rápido processo de aquisições pelas maiores empresas do setor. As principais empresas estrangeiras atuantes no país constam da Tabela 9, nota-se que as maiores redes atualmente pertencem a grupos europeus e americanos, diferentemente da situação no início da década de 1990.

$\mathrm{O}$ crescimento das principais redes iniciou-se nos grandes centros urbanos, principalmente Rio de Janeiro e São Paulo, estendendo-se depois para as cidades do interior dos estados, comprando redes menores e abrindo novas lojas em mercados anteriormente não atendidos pelas grandes firmas. Porém, existe ainda um grande mercado constituído por pequenas cidades e atendido por equipamentos menos sofisticados que podem ser classificados como lojas de sortimento limitado (autoserviço), ou mesmo estabelecimentos comerciais com atendimento personalizado (balcão). A partir do final da década de 1990, as grandes redes passaram a se interessar por este mercado ainda inatingido e iniciaram um movimento de abertura de lojas de sortimento limitado nestes locais de população de poder aquisitivo menor, estratégia similar à utilizada no final dos anos 70 (Martinez, 2000 e Lojudice, 2000).

A segunda metade da década de 90 foi marcada por um ritmo acelerado de fusões e aquisições e aumento dos índices de concentração. As maiores empresas concentraram as compras em empresas de médio porte, geralmente familiares, como mostra a Tabela 12 que possui informações sobre as aquisições das duas maiores redes supermercadistas do país durante o ano 2000. Os principais fatores que explicam o rápido processo de consolidação do varejo são o aumento de poder de barganha do varejista junto aos fornecedores e obtenção de economias de escala pelo maior número de lojas e fluxo de mercadorias (Silva \& Famá, 1999).

O movimento das grandes redes para alcançar altas taxas de crescimento pode ser explicado principalmente por dois fatores: economias de escala e aumento do poder de mercado. As economias de escala permitem obter menores custos médios, distribuindo os custos da utilização de uma mesma estrutura de compra e distribuição para diversas lojas ou para um maior fluxo de mercadorias. A estratégia comum das maiores empresas 
do setor é utilizar centrais de compra de diversos produtos, adquirindo a maior parte dos itens vendidos pelas lojas e deixando para estas a responsabilidade de negociar a compra de um menor número de produtos possível. Além de obter economias de escala, a centralização das compras possibilita exercer o poder de negociação proporcionado pelo maior volume adquirido e diminuição do número de empresas fornecedoras, tornando o varejista um cliente importante para seus fornecedores (Silva \& Famá, 1999).

Tabela 12. Brasil - Super e Hipermercados - Aquisições das Duas Maiores Redes, em 2000.

\begin{tabular}{llc}
\hline Empresa & \multicolumn{1}{c}{ Rede Adquirida } & $\begin{array}{c}\text { Faturamento bruto } \\
\text { (R\$ milhões) }\end{array}$ \\
\hline Carrefour & Big Bom (SP) e Antonelli (SP) & 53 \\
Pão de Açúcar & Mercadinho São Luiz (CE) & 120 \\
& Paulo J. Reimberg (SP) & 125 \\
& Nagumo (SP) & 240 \\
& GePires (SP) & 25 \\
& Senff Parati (PR) & 150 \\
& Supermercados Rosado (SP) & 150 \\
& Cibus / Itapema (SP) & 48 \\
& Boa Esperança (PB) & 100 \\
\hline
\end{tabular}

Fonte: SuperHiper (2001)

O ritmo crescente de fusões e aquisições aumentou os índices de concentração utilizados para ilustrar a participação das maiores empresas no faturamento total do setor. Os índices de concentração das vinte maiores lojas para diversos anos entre as décadas de 80 e 90 se encontram na Tabela 13, na qual observa-se claramente o aumento da participação das maiores redes de supermercados e indica um aumento gradual do poder de seu mercado e pressão competitiva sobre as pequenas empresas do setor.

Apesar da entrada de grandes grupos varejistas americanos e europeus no país e da crescente participação das maiores empresas, o setor supermercadista brasileiro não é considerado concentrado quando são observados os índices relativos, ou seja, a participação das maiores empresas no faturamento total do setor, pois a concentração do 
varejo nacional é substanciamente menor do que em outros países, como se pode observar na Figura 4 (Fernandes \& Neves, 1997). Os índices estão muito abaixo de países como França e Inglaterra, onde as cinco maiores empresas participavam em 1996 com mais de $50 \%$ no faturamento total do setor, enquanto que no Brasil as vinte maiores redes em 1995 participavam com aproximadamente $42 \%$.

Tabela 13. Evolução da participação do faturamento bruto total (\%) e número de lojas das 20 maiores cadeias de supermercados no setor.

\begin{tabular}{lcccccc}
\hline Indicadores & 1980 & 1982 & 1984 & 1995 & 1999 & 2000 \\
\hline Participação no faturamento bruto (\%) & 36,1 & 41,6 & 38,7 & 42,1 & 49,9 & 52,0 \\
Número de lojas & 100 & 144 & 172 & 780 & 1.548 & 1.731 \\
\hline
\end{tabular}

Fonte: Cyrillo (1987); SuperHiper (2001)

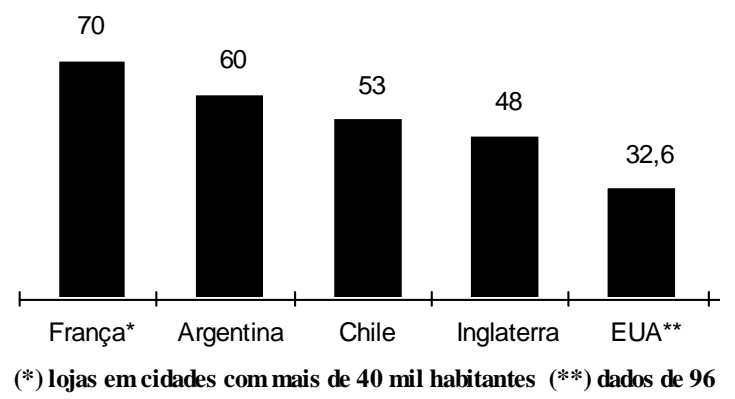

Figura 4 - Participação das cinco maiores redes no faturamento total do setor supermercadista em países selecionados (\%) em 1997.

Fonte Grimbaum \& Fernandes (1998)

O setor supermercadista no Brasil na década de 1980 pode ser classificado como oligopólio diferenciado com franja, isto é, reduzido número de empresas domina a indústria e, à sua volta, existem inúmeros pequenos negócios (de auto-serviço ou não) atendendo mercados ainda não explorados pelas grandes firmas (Cyrillo, 1997). No final da década de 1990, os índices de concentração do setor se encontravam em níveis que o aproximavam desta classificação (Lojudice, 2000).

Analisando a Tabela 14, nota-se que existem 4 empresas que podem ser consideradas os gigantes do setor supermercadista no Brasil, representando $37,1 \%$ do 
faturamento total. As quatro maiores redes seguintes na classificação detêm cerca de oito porcento de participação e as oito empresas seguintes 5,2\%. Deve-se considerar também que existe um número relativamente alto de pequenas empresas, que concorrem utilizando diversas estratégias e que impedem a concentração do setor em número de lojas. Parte considerável destes pequenos negócios, como foi analisados anteriormente, surgiu entre os anos de 1996 e 2000.

Tabela 14. Concentração do setor supermercadista brasileiro em 2000.

\begin{tabular}{lccc}
\hline Índices de concentração & CR4 & CR8 & CR16 \\
\hline Participação (\% do faturamento) & 37,1 & 45,1 & 50,3 \\
\hline
\end{tabular}

Fonte: SuperHiper (2001)

O maior poder de negociação das empresas varejistas provém, além dos fatores anteriormente citados, do rápido acesso às informações de consumo e uso de marcas próprias. $\mathrm{O}$ uso de caixas eletrônicos, que permitem um fluxo de informações constante para elaboração de relatórios gerenciais, e de cartões de fidelidade fornecem ao varejista uma fonte de dados importante sobre o comportamento do consumidor, que pode ou não ser compartilhada com o fornecedor. Portanto, este conhecimento proporcionado pelas novas tecnologias aumenta o poder de mercado do varejo (Silva \& Famá, 1999 e Barbosa, 1999a).

As empresas supermercadistas realizam contratos com indústrias de diversos segmentos para fornecimento de produtos com a sua marca, pois introduzir a marca do varejista na embalagem leva estas firmas a auferirem diversas vantagens. $\mathrm{O}$ uso da marca da empresa varejista em diversos produtos tem como principal objetivo obter a fidelidade do consumidor, transferindo para eles confiança que o cliente tem na empresa. Além disso, as marcas próprias são utilizadas para fortalecer a imagem da loja e completar a linha de produtos (Wedekin \& Neves, 1995). Os produtos com marca própria têm preços 10 a $20 \%$ inferiores que as marcas líderes, pois os custos com propaganda e venda são menores e as lojas podem oferecer produtos de diferentes combinações preço-qualidade (Connor \& Schiek, 1997). 
O aumento do volume comercializado decorrente de fusões e aquisições torna mais fácil a negociação do fornecimento dos produtos para inclusão da marca própria, pois o fabricante diminui a capacidade ociosa tornando a parceria mais interessante. $\mathrm{O}$ fornecedor de itens com marca própria pode ser trocado sem que haja perda de qualidade dos produtos, consequentemente sem que seja percebido pelos consumidores. Portanto, estes itens com a marca do varejista competem fortemente com marcas menos tradicionais, proporcionando aos varejistas um maior poder de negociação junto aos fornecedores, em especial em relação às marcas menos conhecidas (Heijbroek et al., 1994; Fernandes \& Neves, 1997 e Santos \& Gimenez, 2001).

O aumento do consumo de alimentos no Brasil durante a década de 1990 atraiu não apenas empresas varejistas, mas também novas indústrias, nacionais e estrangeiras, desencadeando um processo de fusões e aquisições. A Tabela 15 resume os resultados do processo de internacionalização e concentração de capital em sete das principais indústrias de alimentos no Brasil durante a década de 1990. Pode-se observar que no caso da indústria de soja a participação do capital externo no total das oito maiores empresas era de 10,0\% em 1995 e passou para 43,0\% dois anos depois. Além disso, as quatro maiores empresas aumentaram sua participação na produção total de 31,0\% para $42,5 \%$, indicando um aumento da concentração.

O capital externo aumentou sua participação entre as maiores empresas de todas as indústrias analisadas, nos casos das indústrias de suínos e aves o investimento externo estava ausente até 1993. Dentre algumas empresas estrangeiras que passaram a atuar no Brasil podem ser citadas a Dreyfus (França), da indústria citrícola, a Parmalat (Itália), da indústria do leite, a Bunge (Argentina), da indústria de óleos vegetais e carnes, ADM (USA), da indústria da soja, e Fleischmann-Royal (USA), da indústria de carnes.

Sesso Filho (2001c) analisou o processo de concentração da indústria e varejo de alimentos e observou uma migração do poder de mercado do primeiro para o segundo setor. As informações da literatura são de que as indústrias estão sendo pressionadas a obter aumento de sua eficiência, diminuição de custos de produção e distribuição. Além disso, o ciclo de rápido lançamento de produtos e alta competitividade estimula a indústria a pagar bônus aos varejistas para colocar os produtos no mercado. A alocação 
dos produtos em locais privilegiados dentro das lojas e nas gôndolas assim como a presença de promotores de vendas dentro dos supermercados é paga com prêmios em dinheiro ou vantagens em compras para os supermercadistas (Demarchi \& Tuszel, 2000; Malta \& Nascimento, 1999 e Pacheco, 2000).

Tabela 15. Concentração e internacionalização de capital de sete indústrias de alimentos no Brasil na década de 1990 (em \%).

\begin{tabular}{|c|c|c|c|c|c|}
\hline \multirow[b]{2}{*}{ Indústria } & \multirow[b]{2}{*}{ Ano } & \multirow{2}{*}{$\begin{array}{c}\text { Concentração } \\
\text { CR } 4 *\end{array}$} & \multicolumn{2}{|c|}{ Internacionalização** } & \multirow[b]{2}{*}{$\begin{array}{l}\text { Número de } \\
\text { empresas }\end{array}$} \\
\hline & & & $\begin{array}{c}\text { Capital } \\
\text { Nacional }\end{array}$ & $\begin{array}{l}\text { Capital } \\
\text { Externo }\end{array}$ & \\
\hline \multirow{2}{*}{ Café torrado } & 1990 & 19,7 & 22,0 & 6,0 & \multirow{2}{*}{10} \\
\hline & 1998 & 24,0 & 26,0 & 8,0 & \\
\hline \multirow{2}{*}{ Café solúvel } & 1990 & 79,7 & 94,0 & 6,0 & \multirow{2}{*}{10} \\
\hline & 1998 & 74,5 & 88,0 & 12,0 & \\
\hline \multirow{2}{*}{ Soja } & 1995 & 31,0 & 37,0 & 10,0 & \multirow{2}{*}{8} \\
\hline & 1997 & 42,5 & 12,0 & 43,0 & \\
\hline \multirow{2}{*}{ Suco de laranja } & 1990 & 80,7 & 87,1 & 10,6 & \multirow{2}{*}{10} \\
\hline & 1998 & 82,2 & 75,7 & 24,2 & \\
\hline \multirow{2}{*}{ Lácteos } & 1994 & 37,0 & 26,1 & 20,9 & \multirow{2}{*}{6} \\
\hline & 1998 & 34,5 & 20,4 & 22,0 & \\
\hline \multirow{2}{*}{ Aves } & 1993 & 31,0 & 29,0 & 0,0 & \multirow{2}{*}{10} \\
\hline & 1996 & 31,0 & 35,0 & 14,0 & \\
\hline \multirow{2}{*}{ Suínos } & 1994 & 31,0 & 40,0 & 0,0 & \multirow{2}{*}{10} \\
\hline & 1998 & 47,0 & 54,0 & 10,0 & \\
\hline
\end{tabular}

Fonte: Leme (1999)

* Participação percentual das 4 maiores empresas no volume total de processamento, com exceção da indústria de café solúvel (volume anual exportado).

** Participação percentual do capital nacional e estrangeiro no capital total das empresas analisadas. 


\subsubsection{Estratégias das pequenas empresas supermercadistas}

O aumento da concentração do setor em termos de faturamento bruto e maior poder de mercado das grandes empresas afeta diretamente as pequenas firmas, as quais possuem poucos recursos para adotar novas tecnologias e manterem-se competitivos. Os maiores efeitos são sentidos nos grandes centros urbanos, principais mercado de atuação das grandes redes de varejo. Pode-se citar como exemplo a região da Grande São Paulo, apesar do surgimento de inúmeros pequenos negócios no período 1994/99 nesta localidade os pequenos varejistas passaram a sofrer maior pressão de competição e neste mesmo período três mil pequenos supermercados fecharam (Silva \& Famá, 1999).

As principais formas de reação das pequenas empresas são adequar melhor sua variedade de produtos e formar associações. Os pequenos varejistas têm uma vantagem comparativa de estar mais perto dos consumidores, podendo adequar melhor a variedade de produtos, buscando eficiência na comercialização de produtos de maior conveniência, principalmente perecíveis. A segunda forma de reagir ao avanço das grandes firmas é a formação de associações, as quais em sua maioria são apenas centrais de compras que consolidam os pedidos dos supermercados, diminuindo a importância dos atacadistas. As centrais de compra das associações tornam possível a redução dos preços de aquisição e melhora nas condições de pagamento. Porém, existem associações preocupadas em realizar também serviços de consultoria, treinamento de funcionários e padronização das lojas dos associados, procurando a melhoria na gestão, atendimento aos clientes e apresentação da loja (Barbosa, 1999b).

A realização de associações pode possibilitar também a realizações de campanhas publicitárias e promocionais conjuntas, que teriam custos proibitivos se realizadas individualmente. Desta forma, os associados podem contar com diferencial a mais em relação ao varejo tradicional (Barbosa, 1999b). A Tabela 16 possui dados sobre as principais associações de supermercados existentes no Brasil em 2000, nota-se que a maior parte se encontrava na região sudeste e que algumas possuíam mais de 40 lojas, possibilitando um grande volume de compras. 
Tabela 16. Brasil - Principais Associações de Super e Hipermercados.

\begin{tabular}{|c|c|c|c|}
\hline Empresa & Estado & $\begin{array}{c}\mathrm{N}^{\circ} \mathrm{de} \\
\text { Associados }\end{array}$ & $\mathrm{N}^{\circ}$ de Lojas \\
\hline Arcos & SP & 35 & 63 \\
\hline $\begin{array}{l}\text { Associação Londrinense de Empresários } \\
\text { Supermercadistas (Ales) }\end{array}$ & PR & 28 & 42 \\
\hline Averj & RJ & - & 37 \\
\hline Central de Compras Grande Vitória & ES & 55 & 65 \\
\hline Coopecom & MS & 20 & - \\
\hline Grupo de Compras (SPM) & SP & 4 & 25 \\
\hline Multi Market & RJ & - & 50 \\
\hline Nova Rede & RJ & - & 40 \\
\hline Pague Menos & RJ & - & 23 \\
\hline Preço Baixo & RJ & - & 22 \\
\hline Rede 20 & SP & 13 & 17 \\
\hline Rede Economize & SP & 5 & 8 \\
\hline Rede Líder & MA & 9 & - \\
\hline Rede Master & PR & 17 & 23 \\
\hline RedEconomia & RJ & 13 & 70 \\
\hline
\end{tabular}

Fonte: Saab et al. (2000b)

\subsubsection{Modificações da relação fornecedor-varejista}

As inovações tecnológicas discutidas anteriormente, em conjunto com o maior poder de negociação das grandes redes de varejo, influenciaram o relacionamento varejo-fornecedor tornando mais complexas as relações das cadeias de comercialização. A necessidade de se adaptar rapidamente ao mercado aproximou a indústria do varejo, objetivando obter informações mais detalhadas sobre o consumo de seus produtos. Concomitantemente, as empresas varejistas passaram a exercer maior influência e controle sobre a produção de determinados produtos, principalmente os altamente perecíveis, buscando maior qualidade dos mesmos.

As modificações no relacionamento varejo-indústria ocorreram não apenas para as grandes redes de supermercados, mas também para as pequenas e médias. A indústria, notando o maior poder de barganha dos maiores varejistas, passaram a se preocupar em 
desenvolver novas formas de relacionamento com o mercado participando da criação de associações e incentivando a adoção de novas tecnologias pelas pequenas empresas varejistas.

O estreitamento da relação varejo-fornecedor passa pela principal dificuldade de ambas as partes partilharem informações estratégicas como custos de produção e transporte, vendas dos produtos da própria empresa e dos concorrentes, margens de comercialização e outras menos de menor importância. A disponibilidade dos dados é um fator importante, senão fundamental, para adoção das ferramentas da Resposta Eficiente ao Consumidor (Efficient Consumer Response - ECR), as quais foram analisadas anteriormente.

A interferência das maiores empresas varejistas na produção, utilizando marcas próprias e exigindo e desenvolvendo certificados próprios de qualidade, também foi um fator importante na modificação da relação varejo-fornecedor, a qual anteriormente era de natureza puramente comercial, tornou-se uma parceria na qual o controle de qualidade passou a ser exercido pelo comerciante. As maiores empresas varejistas intensificaram este movimento estratégico no final da década de 1990. As maiores firmas passaram a participar ativamente da produção de produtos hortifrutigranjeiros.

\subsubsection{Dificuldades para a expansão do setor supermercadista}

Apesar da rápida expansão dos supermercados na década de 1970 e do aumento gradativo da atividade nas vendas do varejo nas últimas décadas existem dificuldades para que este alcance a importância que possui em países desenvolvidos como os Estados Unidos e França. A listagem e análise detalhada dos problemas que afetam o varejo não são o principal objetivo do presente trabalho, limitando-se citar e comentar os mais importantes:

- Problemas de clandestinidade e coordenação de cadeias agroalimentares: a produção fora dos padrões legais e atomização da produção pode gerar problemas de relacionamento na cadeia de comercialização e diferenças de competitividade que prejudicam o comércio, pode-se citar o exemplo da carne bovina com abate clandestino em baixas condições de higiene; 
- Ausência ou não-adoção de normas de classificação e padronização de produtos: dificulta a precificação dos produtos e o controle de qualidade, como é o caso dos hortifrútis, que devem ter classificação e padronização determinadas pelo tamanho, forma, cor e outros atributos;

- Sonegação fiscal: a possibilidade de sonegação é ainda um fator importante na determinação dos preços dos produtos, existindo ainda ampla gama de negócios que se beneficiam da falha da fiscalização;

- Problemas institucionais: a entrada ilegal de produtos (contrabando) e o roubo de cargas prejudicam a competitividade do setor supermercadista. O segundo problema gera, além da possibilidade do receptador vender a preços menores, custos para as transportadoras como seguros e fretes mais caros que são incorporados no preço final do produto, prejudicando as vendas ao consumidor;

- Tributação: altas alíquotas, em conjunto com a falta de fiscalização adequada, tornam lucrativa a sonegação fiscal permitindo a comercialização a preços menores e prejudicando a competitividade das empresas que pagam seus impostos devidamente (SuperHiper, Revista da Associação Brasileira de Supermercados).

\subsubsection{Síntese das tendências da distribuição de alimentos na década de 1990}

As principais tendências da distribuição de alimentos no Brasil durante a década de 1990 estão resumidas na quadro 1. O resultado final é um setor supermercadista mais dinâmico e um ambiente de negócios que requer altos investimentos em tecnologia e adaptação rápida a mudanças no ambiente competitivo como a entrada de novas empresas e modificações do comportamento do consumidor. Observa-se também o aumento de poder de negociação das maiores empresas junto a seus fornecedores, algumas razões são a concentração do mercado, o grande fluxo de informações sobre vendas e o uso de marcas próprias. Portanto, o setor supermercadista lidera as grandes transformações na distribuição de alimentos no país, constituindo-se no principal equipamento de comercialização dos produtos. 


\begin{tabular}{|l|l|}
\hline Tendências & Conseqüências \\
\hline Entrada de novas empresas & Aumento da pressão competitiva \\
\hline Concentração & $\begin{array}{l}\text { Pressão sobre os pequenos varejistas e } \\
\text { fornecedores }\end{array}$ \\
\hline Marcas próprias & $\begin{array}{l}\text { Menor ciclo de vida dos produtos; } \\
\text { Limitação de espaço na gôndola }\end{array}$ \\
\hline Automação Comercial & $\begin{array}{l}\text { Aumento do poder de negociação dos } \\
\text { varejistas junto aos fornecedores }\end{array}$ \\
\hline Frente & $\begin{array}{l}\text { Atendimento mais rápido do cliente; } \\
\text { Diminuição do número de caixas; } \\
\text { Ganho de espaço de exposição e } \\
\text { Menor necessidade de mão-de-obra. }\end{array}$ \\
\hline Transferência Eletrônica de Informação & $\begin{array}{l}\text { Melhor gerenciamento dos estoques e } \\
\text { Menor necessidade de mão-de-obra. }\end{array}$ \\
\hline Ferramentas ECR & $\begin{array}{l}\text { Fluxo rápido de informações; } \\
\text { Diminuição de erros e } \\
\text { Menor necessidade de mão-de-obra. }\end{array}$ \\
$\begin{array}{l}\text { Rápido fluxo de mercadorias; } \\
\text { Menores custos para toda a cadeia de } \\
\text { comercialização e } \\
\text { Melhor atendimento ao consumidor. }\end{array}$ \\
\hline
\end{tabular}

Quadro 1 - Principais tendências da distribuição de alimentos no Brasil na década de 1990.

Fonte: Sesso Filho (2001a)

\subsubsection{Síntese da expansão dos supermercados no Brasil e importância econômica}

O quadro 2 resume a introdução e expansão do setor supermercadista no país até o final da década de 1990. Apesar dos problemas iniciais ao desenvolvimento das empresas, os supermercados se estabeleceram como principal equipamento de comercialização a partir do início da década de 70, passando a assumir importante papel social. Na década de 1990, o setor se modernizou rapidamente passando a utilizar as novas tecnologias disponíveis no mercado, além de se adaptar às exigências de qualidade e variedade da demanda, também acompanhada da indústria de alimentos. 


\begin{tabular}{|l|l|}
\hline Período & Características \\
\hline $\begin{array}{l}\text { 1952-65 Introdução dos } \\
\text { Supermercadosno Brasil }\end{array}$ & $\begin{array}{l}\text { Necessidade de atender ao grande volume } \\
\text { comercializado; } \\
\text { Barreiras à entrada. }\end{array}$ \\
\hline $\begin{array}{l}\text { 1965-74 Rápida Expansão do } \\
\text { Setor Supermercadista } \\
\text { Abertura de lojas de formato hipermercado; } \\
\text { Simpatia do novo regime; } \\
\text { Concentração; } \\
\text { Consolidação da posição como principal equipamento } \\
\text { de comercialização do varejo. }\end{array}$ \\
\hline $\begin{array}{l}\text { 1975-85 Desaceleração do } \\
\text { Crescimento }\end{array}$ & $\begin{array}{l}\text { Introdução das lojas de sortimento limitado; } \\
\text { Acelerado processo de fusões e aquisições. }\end{array}$ \\
\hline 1986-94 Adaptação à Crise & $\begin{array}{l}\text { Aumento do número de lojas de sortimento limitado; } \\
\text { Expansão das maiores empresas; } \\
\text { Diminuição do crescimento do setor. }\end{array}$ \\
\hline 1995 - Modernização & $\begin{array}{l}\text { Uso de novas tecnologias; } \\
\text { Modificações nas relações com fornecedores; } \\
\text { Novo processo de fusões e aquisições; } \\
\text { Lançamento rápido de novos produtos; } \\
\text { Maior conhecimento do consumidor; } \\
\text { Migração de poder de mercado da indústria para o } \\
\text { varejo; }\end{array}$ \\
\hline
\end{tabular}

Quadro 2 - Síntese da expansão dos supermercados no Brasil.

Fonte: elaborada pelo autor.

A síntese da expansão dos supermercados no Brasil permite concluir que as grandes transformações em termos de uso de tecnologia, aumento de faturamento e índices de desempenho ocorreram ao longo da década de 1990, o que justifica focar a análise do estudo neste período. Para ilustrar a seqüência dos acontecimentos elaborouse a Figura 5, a qual resume as principais modificações do setor ao longo da década. A Figura mostra um encadeamento de fatores, que foi analisado detalhadamente no decorrer do texto. 


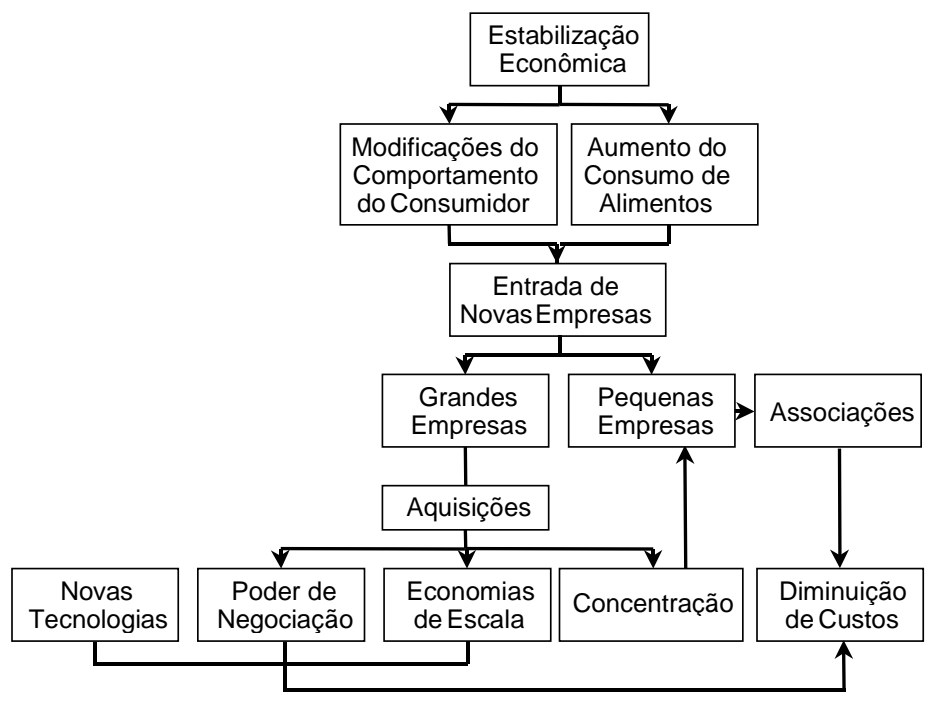

Figura 5 - Transformações do setor supermercadista na década de 1990.

Fonte: Wilder \& Sesso Filho (2002)

Resumidamente, o varejo de alimentos na década de 1990 foi marcado por diversas transformações, notadamente após 1994, ano da estabilização econômica. As modificações do ambiente macroeconômico influenciaram o comportamento do consumidor e a demanda por alimentos, atraindo inúmeras novas empresas nacionais e estrangeiras. O uso de novas tecnologias por parte de varejistas e fornecedores, como automação comercial, transferência eletrônica de dados e ferramentas da chamada Resposta Eficiente ao Consumidor (ECR) tornaram possível a diminuição de custos e crescimento das empresas varejistas.

O ciclo de fusões e aquisições aumentou a concentração do setor e passou a preocupar as pequenas empresas, as quais são responsáveis pela maior parte do faturamento da indústria, o que levantou dúvidas sobre a sobrevivência da maioria das lojas independentes. As menores firmas passaram a se unir em associações em busca de diminuição de custos de compra e distribuição e outras vantagens como treinamento de funcionários e propaganda conjunta.

As transformações citadas promoveram a migração de poder de mercado da indústria para o varejo, pressionando as margens de comercialização dos fornecedores e obrigando-os a encontrar formas de diminuir seus custos de produção e distribuição. 
As Tabelas 17 e 18 mostram a evolução do faturamento do setor e das maiores empresas na década de 1990. A Figura 6 foi elaborada com os dados da Tabela 18 para melhor ilustrar a evolução do faturamento das maiores firmas do setor. Pode-se observar que o faturamento total do setor aumentou substancialmente após 1994, ano da implantação do Plano Real, sendo que nos dois anos posteriores tanto as vinte maiores empresas como o conjunto formado pelas outras duzentos e oitenta na classificação aumentaram seu faturamento total. Porém, a partir de 1996 observa-se um aumento expressivo da participação das vinte maiores empresas em detrimento das outras como conseqüência do processo de fusões e aquisições.

Tabela 17. Indicadores econômicos do auto-serviço alimentar brasileiro no período $1995 / 2000$.

\begin{tabular}{lrrrrrr}
\hline Seç̃̃es & 1995 & \multicolumn{1}{c}{1996} & 1997 & 1998 & 1999 & \multicolumn{1}{c}{2000} \\
\hline Número de lojas & 41.839 & 43.763 & 47.787 & 51.502 & 55.313 & 61.259 \\
Faturamento anual & 40,6 & 46,8 & 50,4 & 55,5 & 60,1 & 67,6 \\
(em bilhões nominais) & 655.200 & 625.000 & 655.000 & 666.752 & 670.086 & 701.622 \\
Número de empregos diretos & n.d. & n.d. & 12 & 12,7 & 13,1 & 14,3 \\
Área de vendas & n.d. & n.d. & 123.170 & 125.867 & 135.914 & 143.705 \\
(em milhões m2) & & & & & & \\
Número de caixas & & & & &
\end{tabular}

Fonte: SuperHiper (2001)

n.d. = não disponível

Tabela 18. Evolução do faturamento* das 300 maiores empresas do setor supermercadista e participação no faturamento das 20 maiores redes.

\begin{tabular}{lrrrrrrrrrrr}
\hline Grupos & 1990 & 1991 & 1992 & 1993 & 1994 & 1995 & 1996 & 1997 & 1998 & 1999 & 2000 \\
\hline 300 maiores & 100 & 89 & 94 & 98 & 109 & 125 & 121 & 122 & 129 & 126 & 127 \\
20 maiores & 100 & 86 & 87 & 90 & 101 & 115 & 115 & 118 & 138 & 134 & 138 \\
280 outras & 100 & 96 & 104 & 110 & 124 & 141 & 129 & 129 & 113 & 113 & 108 \\
\hline
\end{tabular}

Fonte: SuperHiper (2001)

* índice do faturamento real de base de dezembro de 2000. 


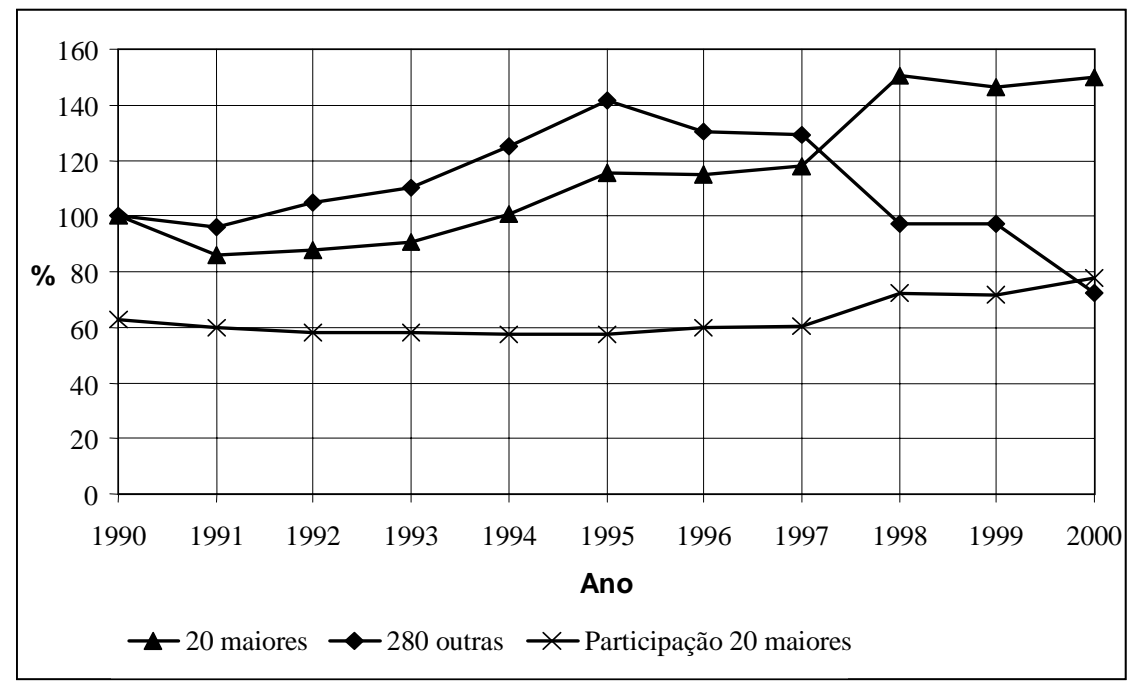

Figura 6 - Evolução do índice do faturamento das 300 maiores empresas do setor e participação das 20 maiores empresas no faturamento anual.

Fonte: SuperHiper (2001)

Apesar do crescimento da importância do setor supermercadista como empregador, há grande dificuldade em encontrar pesquisas em profundidade da sua capacidade de geração de empregos. O setor supermercadista superou substancialmente em número de empregos diretos diversas indústrias. Os dados contidos na Tabela 16 permitem comparar o setor supermercadista com outros dois setores importantes na economia brasileira: eletroeletrônicos e automotivo. Nota-se que o número de empregos diretos gerados é favorável aos supermercados, pois o número de pessoas ocupadas cresceu no setor supermercadista, enquanto que nos setores de Equipamentos eletrônicos e Indústria Automotiva o número de funcionários diminuiu substancialmente.

Tabela 19. Empregos diretos de setores da economia brasileira.

\begin{tabular}{lrrrrr}
\hline Indústria & \multicolumn{1}{c}{1995} & \multicolumn{1}{c}{1996} & \multicolumn{1}{c}{1997} & \multicolumn{1}{c}{1998} & \multicolumn{1}{c}{1999} \\
\hline Setor supermercadista & 655.200 & 625.000 & 655.000 & 666.752 & 670.086 \\
Equipamentos eletrônicos & 122.800 & 112.900 & 108.700 & 89.300 & 71.354 \\
Indústria automotiva & 87.900 & 79.200 & 81.800 & 65.400 & 56.340 \\
\hline
\end{tabular}

Fonte: IBGE (2002); SuperHiper (2001) 
O setor passou a participar, ao longo dos anos, das vendas de diversos tipos de produtos em especial nas lojas maiores, para as quais parte substancial do faturamento é com a venda de itens não alimentos. A Tabela 20 possui dados sobre a participação de cada grupo de produtos (seções) no faturamento bruto do setor e a Figura 7 ilustra a participação das diversas seções no faturamento dos supermercados para o ano de 2000 . Os dados resultam de pesquisa da Associação Brasileira de Supermercados abrangendo aproximadamente $57 \%$ do faturamento do setor. Nota-se que a maior parte das vendas é proveniente da comercialização de alimentos, in natura ou industrializados. Porém, cresce a participação de itens não-alimentos, como eletrônicos e utensílios domésticos (bazar), devido à abertura de lojas com área de vendas acima de 5.000 metros quadrados denominadas Superlojas e, quando maiores, Hipermercados e Supercenters. Estes formatos de lojas comercializam um grande número de produtos não-alimentícios.

Tabela 20. Participação das seções de produtos no faturamento total do setor supermercadista em 2000/2001.

\begin{tabular}{lcc}
\hline Seções & 2000 & 2001 \\
\hline Mercearia seca & $21 \%$ & $21,1 \%$ \\
Mercearia líquida & 14,9 & 11,9 \\
Frios e laticínios & 13,6 & 13,2 \\
Higiene e perfumaria & 7,6 & 7,6 \\
Açougue & 6,9 & 7,4 \\
Bazar & 6,9 & 7,0 \\
Eletroeletrônicos & 6,9 & 7,0 \\
Limpeza & 6,7 & 6,8 \\
Hortifrúti & 6,3 & 6,8 \\
Congelados & 3,3 & 4,0 \\
Padaria & 2,6 & 2,9 \\
Têxtil & 2,5 & 2,9 \\
Peixaria & 0,8 & 0,9 \\
Outros & - & 0,6 \\
Faturamento bruto nominal & $\mathrm{R} \$ 67,6$ bilhões & $\mathrm{R} \$ 72,5$ bilhões \\
\hline
\end{tabular}

Fonte: SuperHiper (2001); SuperHiper (2002) 


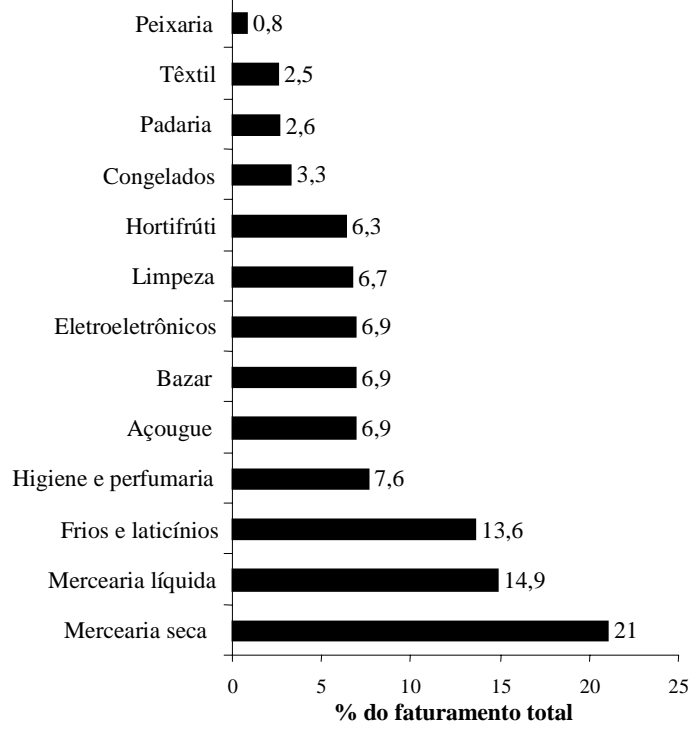

Figura 7 - Participação das seções no faturamento total das lojas do setor supermercadista no ano de 2000.

Fonte: SuperHiper (2001)

O capítulo teórico a seguir aborda a teoria de insumo-produto e o cálculo de indicadores econômicos para a análise setorial objetiva especificar as ferramentas de análise que foram utilizadas na pesquisa. Além disso, a metodologia de desagregação do setor supermercadista na matriz de insumo-produto para o Brasil para os anos de 1990, 1995 e 1999 e as fontes de dados da pesquisa. 


\section{METODOLOGIA}

\subsection{Teoria Insumo-produto}

A obra do francês François Quesnay, o Tableau Economique (1758), evidenciou a preocupação em estabelecer e analisar a interdependência econômica entre os diversos ramos da economia. Quase um século depois em 1874, Léon Walras publicava Éléments d'économie Politique Pure, obra na qual pretendia determinar todos os preços na economia, realizando a transição do equilíbrio parcial para o equilíbrio geral (Guilhoto, 2000).

Na década de 1930, Wassily Leontief construiu a primeira matriz de insumo-produto para a análise da economia norte-americana. A análise de insumo-produto é uma aplicação da teoria clássica de interdependência entre os setores da economia, que propõe interpretar as suas funções baseando-se em suas propriedades específicas mensuráveis de sua estrutura. O modelo de Leontief torna possível determinar como o funcionamento de um determinado setor/indústria relaciona-se aos demais (Miernyk, 1974). O modelo de insumo-produto de Leontief é constituído por um sistema de equações lineares, as quais representam a distribuição da produção dentro da economia. No início, procurou-se obter os dados da contabilidade detalhada das transações entre os setores em unidades físicas. Entretanto, devido ao fato de mais de um produto ser vendido por setor surgiram problemas de mensuração dos fluxos intersetoriais, o que levou à representação da matriz de insumoproduto em termos monetários (Guilhoto, 2000).

O Quadro 3 ilustra as informações do modelo de insumo-produto, o qual descreve os insumos e as produções dos diferentes setores da economia para um período determinado. As linhas representam a distribuição da produção de cada setor no sistema econômico e as colunas apresentam os insumos absorvidos pelos setores para sua produção. 


\begin{tabular}{|c|c|c|c|c|c|c|c|c|c|c|}
\hline & \multicolumn{8}{|c|}{ Setores compradores (j) } & \multirow{3}{*}{$\begin{array}{c}\text { Valor } \\
\text { bruto } \\
\text { da } \\
\text { produção }\end{array}$} \\
\hline & & \multicolumn{3}{|c|}{ Demanda Intermediária } & \multicolumn{5}{|c|}{ Demanda final } & \\
\hline & & $\begin{array}{c}\text { Setor } \\
1 \\
\end{array}$ & $\begin{array}{c}\text { Setor } \\
2 \\
\end{array}$ & $\begin{array}{c}\text { Sub-total } \\
\text { (dem. Inter } \\
\text { mediária) }\end{array}$ & $\begin{array}{l}\text { Con- } \\
\text { sumo }\end{array}$ & $\begin{array}{c}\text { Inves- } \\
\text { timento }\end{array}$ & $\begin{array}{l}\text { Gasto do } \\
\text { Governo }\end{array}$ & $\begin{array}{l}\text { Expor- } \\
\text { tações }\end{array}$ & $\begin{array}{c}\text { Sub-total } \\
\text { (demand } \\
\text { a final) }\end{array}$ & \\
\hline \multirow{2}{*}{$\begin{array}{l}\text { Setores } \\
\text { Vendedores } \\
\text { (i) }\end{array}$} & Setor 1 & $\mathrm{z}_{11}$ & $\mathrm{z}_{12}$ & $\sum_{j=1}^{n} Z_{1 j}$ & $\mathrm{C}_{1}$ & $\mathrm{I}_{1}$ & $\mathrm{G}_{1}$ & $\mathrm{E}_{1}$ & $\mathrm{Y}_{1}$ & $\mathrm{X}_{1}$ \\
\hline & Setor 2 & $\mathrm{z}_{21}$ & $\mathrm{z}_{22}$ & $\sum_{j=1}^{n} Z_{2 j}$ & $\mathrm{C}_{2}$ & $\mathrm{I}_{2}$ & $\mathrm{G}_{2}$ & $\mathrm{E}_{2}$ & $\mathrm{Y}_{2}$ & $\mathrm{X}_{2}$ \\
\hline \multicolumn{2}{|c|}{ Sub-total } & $\sum_{i=1}^{n} Z_{i 1}$ & $\sum_{i=1}^{n} Z_{i 2}$ & $\sum_{i, j=1}^{n} Z_{i j}$ & $\sum_{i=1}^{n} C_{i}$ & $\sum_{i=1}^{n} I_{i}$ & $\sum_{i=1}^{n} G_{i}$ & $\sum_{i=1}^{n} E_{i}$ & $\sum_{i=1}^{n} Y_{i}$ & $\sum_{i=1}^{n} X_{i}$ \\
\hline \multicolumn{2}{|c|}{ Importações } & $\mathrm{IM}_{1}$ & $\mathrm{IM}_{2}$ & $\sum_{j=1}^{n} I M_{j}^{D I}$ & IMC & IMI & IMG & IME & $\mathrm{IM}^{\mathrm{Y}}$ & \\
\hline \multicolumn{2}{|c|}{ Tributos } & $\mathrm{N}_{1}$ & $\mathrm{~N}_{2}$ & $\sum_{j=1}^{n} N_{j}$ & $\mathrm{NC}$ & NI & NG & $\mathrm{NE}$ & $\mathrm{N}^{\mathrm{Y}}$ & \\
\hline \multicolumn{2}{|c|}{ Salários } & $\mathrm{L}_{1}$ & $\mathrm{~L}_{2}$ & $\sum_{j=1}^{n} L_{j}$ & & & & & & \\
\hline \multicolumn{2}{|c|}{ Valor adicionado } & $\mathrm{VA}_{1}$ & $\mathrm{VA}_{2}$ & $\sum_{j=1}^{n} V A_{j}$ & & & & & & \\
\hline \multicolumn{2}{|c|}{$\begin{array}{l}\text { Valor bruto da } \\
\text { produção }\end{array}$} & $\mathrm{X}_{1}$ & $\mathrm{X}_{2}$ & $\sum_{j=1}^{n} X_{j}$ & & & & & & \\
\hline
\end{tabular}

Quadro 3 - Matriz de Insumo-Produto para dois setores.

Fonte: Crócomo (1998)

Onde:

$\mathrm{Z}_{\mathrm{ij}} \quad$ fornecimento de insumos do setor i para o setor $\mathrm{j}$;

$\mathrm{C}_{\mathrm{i}} \quad$ fornecimento de insumos do setor i destinado ao consumo final privado;

$\mathrm{I}_{\mathrm{i}} \quad$ fornecimento do setor i destinado ao investimento privado;

$\mathrm{G}_{\mathrm{i}}$ fornecimento do setor i destinado ao Governo (consumo mais investimento do Governo);

$\mathrm{E}_{\mathrm{i}} \quad$ fornecimento do setor i destinado às exportações para o resto do mundo; 
$\mathrm{Y}_{\mathrm{i}} \quad$ total da demanda final atendida pelo setor $\mathrm{i},\left(\mathrm{C}_{\mathrm{i}}+\mathrm{I}_{\mathrm{i}}+\mathrm{G}_{\mathrm{i}}+\mathrm{E}_{\mathrm{i}}\right)$;

$\mathrm{X}_{\mathrm{i}} \quad$ produção bruta do setor $\mathrm{i}$;

$\mathrm{Im}_{\mathrm{j}} \quad$ importação do setor $\mathrm{j}$;

$\mathrm{L}_{\mathrm{j}} \quad$ salários pagos pelo setor $\mathrm{j}$ no processo de sua produção;

$\mathrm{N}_{\mathrm{j}} \quad$ aluguéis, juros, lucros, tributos indiretos líquidos pagos pelo setor $\mathrm{j}$;

$\mathrm{VA}_{\mathrm{j}} \quad$ valor adicionado $(\mathrm{Lj}+\mathrm{Nj})$;

$\sum_{j=1}^{n} I M_{j}^{D I}$ total das importações do setor j, para a demanda intermediária;

IMC importações destinadas a bens de consumo;

IMI importações destinadas a bens de investimento;

IMG importações destinadas aos gastos do Governo;

IME importações destinadas às exportações;

$\mathrm{IM}^{\mathrm{Y}}$ total das importações destinadas para a demanda final

Dadas as definiçõos anteriores e baseando-se no Quadro 3, pode-se estabelecer um conjunto de igualdades representativas do funcionamento do sistema econômico:

Pelo vetor linha:

$$
\begin{gathered}
\sum_{j=1}^{n} z_{i j}=z_{i 1}+z_{i 2} \text { e } Y_{i}=C_{i}+I_{i}+G_{i}+E_{i} \\
X_{i}=\sum_{j=1}^{n} z_{i j}+Y_{i}
\end{gathered}
$$

Pelo vetor coluna:

$$
\sum_{j=1}^{n} z_{i j}=z_{1 j}+z_{2 j} e V A_{j}=L_{j}+N_{j} \text { eX } X_{j}=\sum_{i=1}^{n} z_{i j}+V A_{j}+I M_{j}
$$

As equações representam duas formas de cálculo do valor bruto da produção, considerando-se a igualdade estabelecida por (2) define-se um sistema de equações lineares simultâneas, cujos parâmetros são estimados empiricamente, demonstrados como:

$$
X_{i}=z_{i 1}+z_{i 2}+\ldots+z_{i j}+Y_{i}
$$


É possível construir uma equação para cada um dos $n$ setores (i e j=1,2, .. n). Admite-se, no modelo de Leontief, que a quantidade de insumo no setor i utilizado pelo setor $\mathrm{j}$ é diretamente proporcional à produção do setor $\mathrm{j}$, pode-se então calcular os coeficientes técnicos de produção $\mathrm{a}_{\mathrm{ij}}$ :

$$
a_{i j}=\frac{z_{i j}}{X j}
$$

$\mathrm{O}$ coeficiente técnico representa uma relação de quanto o setor $\mathrm{j}$ compra do setor $\mathrm{i}$ dada a produção total do setor $\mathrm{j}$ denominada $\mathrm{X}_{\mathrm{j}}$. Os coeficientes técnicos de produção constituem relações fixas entre os setores e seus insumos. Portanto, a economia de escala é ignorada, os retornos são constantes à escala, o modelo considera que os setores utilizam insumos em proporções fixas. Os coeficientes técnicos podem ser reescritos da seguinte forma:

$$
\mathrm{Z}_{\mathrm{ij}}=\mathrm{a}_{\mathrm{ij}} \mathrm{X}_{\mathrm{j}}
$$

e, a equação (4) pode ser reescrita como:

$$
X_{i}=a_{i 1} X_{1}+a_{i 2} X_{2}+\ldots+a_{i i} X_{i}+\ldots+a_{i n} X_{n}+Y_{i}
$$

A equação representa um sistema de equações lineares simultâneas que possuem como parâmetros os coeficientes técnicos de produção. Isolando-se $\mathrm{Y}_{1}$ e colocando $\mathrm{X}_{1}$ em evidência, temos:

$$
\left(1-a_{\mathrm{i} 1}\right) X_{1}-a_{\mathrm{i} 2} X_{2}-\ldots-a_{\mathrm{ii}} X_{\mathrm{i}}-\ldots-\mathrm{a}_{\mathrm{in}} \mathrm{X}_{\mathrm{n}}=\mathrm{Y}_{\mathrm{i}}
$$

Pode-se definir, de forma genérica, as matrizes:

$$
\mathbf{A}=\left[\begin{array}{cccccc}
\mathbf{a}_{11} & \mathbf{a}_{12} & \cdots & \mathbf{a}_{1 \mathrm{i}} & \cdots & \mathbf{a}_{1 \mathrm{n}} \\
\mathbf{a}_{21} & \mathbf{a}_{22} & \cdots & \mathbf{a}_{2 \mathbf{2}} & \cdots & \mathbf{a}_{2 \mathrm{n}} \\
\vdots & \vdots & \vdots & \vdots & \vdots & \vdots \\
\mathbf{a}_{\mathrm{n} 1} & \mathbf{a}_{\mathrm{n} 2} & \cdots & \mathbf{a}_{\mathrm{ni}} & \cdots & \mathbf{a}_{\mathrm{nn}}
\end{array}\right] \text { (9) } \quad \mathbf{X}=\left[\begin{array}{c}
\mathbf{X}_{1} \\
\mathbf{X}_{2} \\
\vdots \\
\mathbf{X}_{\mathrm{n}}
\end{array}\right] \quad \text { (10) } \mathbf{Y}=\left[\begin{array}{c}
\mathbf{Y}_{1} \\
\mathbf{Y}_{2} \\
\vdots \\
\mathbf{Y}_{\mathbf{n}}
\end{array}\right]
$$


A é a matriz de coeficientes técnicos, de ordem ( $\mathrm{n} \times \mathrm{n})$;

$\mathrm{X} \quad$ vetor do valor bruto da produção, de ordem (n x 1);

Y vetor da demanda final total, de ordem ( $\mathrm{n} \times \mathrm{n})$.

As relações representadas podem ser apresentadas em forma matricial, como:

$$
A X+Y=X
$$

onde: X e Y são vetores colunas de ordem (n x 1).

De acordo com Miller \& Blair (1985), as variações na demanda final, Y, são determinadas exogenamente e a produção total, $X$, pode ser obtida da seguinte forma:

$$
X=(1-A)^{-1} Y
$$

Onde $(I-A)^{-1}$ é a matriz de coeficientes técnicos de insumos diretos e indiretos, ou a matriz inversa de Leontief, a qual capta os efeitos diretos e indiretos das modificações exógenas da demanda final sobre a produção dos $\mathrm{n}$ setores. Especificamente, a matriz mostra os requisitos diretos e indiretos da produção total do setor i necessários para produzir uma unidade de demanda final do setor $\mathrm{j}$ (Miller \& Blair, 1985). Portanto, podem ser avaliados os impactos de políticas setoriais sobre outros setores e no total nacional. Pode-se apontar uma série de pressupostos em que se baseia a teoria insumo-produto, as quais se constituem em limitações da análise:

a) Equilíbrio geral da economia a um dado nível de preços;

b) Inexistência de ilusão monetária dos agentes econômicos;

c) Retornos constantes à escala;

d) Preços constantes;

e) Supõe-se que as mudanças tecnológicas são lentas;

f) Todos os bens e serviços incluídos na matriz apresentam uma oferta infinitamente elástica, ou seja, toda a demanda adicional será coberta expandindo-se a produção aos custos representados na matriz (Miernyk, 1974 e Guilhoto et al., 2000). 


\subsection{Análise setorial}

As limitações da análise da economia utilizando-se a teoria insumo-produto citadas anteriormente não impediram sua aplicação para diversos fins como análise setorial, impacto de políticas econômicas, distribuição de renda e meio ambiente. Estas são algumas das áreas para as quais pode ser utilizado o modelo inicialmente desenvolvido por Leontief. Para o presente estudo, a análise setorial do setor supermercadista brasileiro, o modelo será utilizado para determinar indicadores econômicos importantes para avaliar a importância e o impacto das transformações do setor supermercadista sobre a economia.

A partir das relações fundamentais descritas, pode-se calcular diversos indicadores econômicos que permitem avaliar o impacto do comportamento de um determinado setor/indústria sobre a economia em termos de geração de produção, renda, salários, empregos e outras variáveis importantes.

\subsubsection{Ligações intersetoriais e setores-chave}

A análise das relações intersetoriais da economia de um país ou região utilizando-se o modelo insumo-produto, no qual a demanda final é autônoma, torna possível determinar a produção em cada setor e seus efeitos sobre os outros para uma dada variação da demanda final, ou seja, as ligações intersetoriais.

As ligações intersetoriais podem ser mensuradas por diversos métodos, objetivando-se identificar os setores-chave para os quais dever-se-ia preferencialmente direcionar/concentrar recursos humanos e físicos, permitindo obter um crescimento mais rápido do produto e do emprego na economia do que se estes recursos fossem investidos em outros setores (McGilvray, 1977).

Apesar do consenso da existência de que um número relativamente pequeno de setores dentro da economia capazes de gerar crescimento econômico há divergência em relação ao melhor método para identificar os setores-chave, sendo a seguir discutidas três metodologias complementares: índices de ligação de Rasmussen-Hirschman, o Campo de Influência e os Índices Puros de Ligação. Além dos índices de ligações intersetoriais, deve-ser considerar ainda a análise dos multiplicadores de produção, 
emprego e renda setorial a fim de determinar quais as atividades econômicas devem ser estimuladas para atingir metas de políticas econômicas específicas.

\subsubsection{1 Índices de Rasmussen-Hirschman}

Os índices de ligações de Rasmussen-Hirschman foram idealizados por Rasmussen (1956) e posteriormente desenvolvidos por Hirschman (1958) para identificar setores-chave na economia. Os valores calculados para os índices de ligações para trás indicam quanto o setor demanda de outros setores da economia, enquanto os índices de ligações para frente mostram o quanto o setor é demandado pelas outras indústrias.

Os índices se baseiam na equação $L=(I-A)^{-1}$, a matriz inversa de Leontief, podendo-se definir $1_{\mathrm{ij}}$ como sendo um elemento da matriz $L$ e obter $L^{* *}$, que é a média de todos os elementos de $L$, assim como calcular $L_{\bullet j}$ e $L_{\mathrm{i}} \bullet$ que constituem as somas dos elementos de uma coluna e de uma linha típica de $L$ e n é o número total de setores na economia. Algebricamente, temos:

$$
L_{i \bullet}=\sum_{j=1}^{n} l_{i j} \quad \text { e } \quad L_{i \bullet}=\sum_{j=1}^{n} l_{i j} \quad \mathrm{i}, \mathrm{j}=1,2, \ldots \mathrm{n}
$$

Assim, pode-se determinar:

Índices de ligações para trás (poder de dispersão):

$$
U_{j}=\left[L_{\bullet j} / n\right] / L^{*}
$$

Índices de ligações para frente (sensibilidade da dispersão):

$$
U_{i}=\left[L_{i} / n\right] / L^{*}
$$

Os valores calculados para os índices de ligações são relativos à média, considerando-se valores maiores que um para índices de ligações para trás ou para frente indicadores de setores acima da média, portanto, setores-chave para o crescimento da economia. 


\subsubsection{Campo de influência}

O enfoque de campo de influência desenvolvido por Sonis e Hewings (1989) e Sonis e Hewings ${ }^{2}$ visa resolver ou minimizar problemas apresentados pelos índices de ligações de Rasmussen-Hirschman, os quais possibilitam avaliar a importância dos impactos de cada setor sobre a economia, porém não permitem determinar os principais elos de ligação, ou seja, as relações entre setores mais importantes dentro da economia e cujas variações dos coeficientes teriam maiores impactos sobre o sistema. Portanto, o enfoque do campo de influência complementa a análise dos índices de ligações para frente e para trás.

A matriz de coeficientes técnicos de produção $A=\left|a_{i j}\right|$ e a matriz de variações incrementais nos coeficientes diretos de insumo, $\mathrm{E}=\left|\varepsilon_{\mathrm{ij}}\right|$ são utilizadas para o cálculo do campo de influência. As matrizes inversas de Leontief são $L=(I-A)^{-1}$ e $L(\varepsilon)=[I-A+\varepsilon)]^{-1}=\left|1_{i j}(\varepsilon)\right|$. De acordo com Sonis e Hewings (1989 e 1994), caso a variação seja pequena e só ocorra num coeficiente direto, isto é:

$$
\varepsilon_{i j}= \begin{cases}\varepsilon & i=i_{1}, j=j_{1} \\ 0 & i \neq i_{1} \text { ou } j \neq j_{1}\end{cases}
$$

O campo de influência desta variação pode ser aproximado pela expressão:

$$
F\left(\varepsilon_{i j}\right)=\frac{\left\lfloor L\left(\varepsilon_{i j}\right)-L\right\rfloor}{\varepsilon_{i j}}
$$

Em que $F\left(\varepsilon_{i j}\right)$ é a matriz (n x n) do campo de influência do coeficiente $a_{i j}$.

Para determinar quais coeficientes possuem o maior campo de influência, associa-se a cada matriz $\mathrm{F}\left(\varepsilon_{\mathrm{ij}}\right)$ um valor que é dado por:

$$
S_{i j}=\sum_{k=1}^{n} \sum_{l=1}^{n}\left[f_{k l}\left(\varepsilon_{i j}\right)\right]^{2}
$$

${ }^{2}$ SONIS, M.; HEWINGS, G.J.D. Fields of influence in input-output systems. Urbana: University of Illinois, Regional Economics Applications Laboratory, 1994. 
Portanto, os setores-chave da economia são aqueles que possuem os maiores coeficientes $S_{\mathrm{ij}}$, ou seja, os maiores campos de influência.

\subsubsection{Abordagem GHS: índices puros de ligação}

Os índices de ligações de Rasmussen-Hirschman não levam em consideração os níveis de produção de cada setor analisado. As tentativas de resolver ou minimizar esta deficiência iniciaram-se com Cella (1984) e Clements (1990), sendo que Guilhoto et al. (1994) utilizaram os conceitos desenvolvidos por tais autores para calcular o índice puro de ligações, aprimorado em Guilhoto et al. (1996). A abordagem proposta determina a importância do setor para o resto da economia em termos da produção de cada setor e da interação deste com outros setores, minimizando as limitações dos índices de ligações para frente e para trás.

Os trabalhos de Guilhoto et al. (1994) e Guilhoto et al. (1996) procuram unir dois índices, criados para propósitos diferentes: os índices de ligações de RasmussenHirschman e o proposto por Miyazawa (1976). O primeiro determina os impactos isolados de um setor no restante da economia e o segundo tem o propósito de determinar as fontes de variações na economia e o papel das ligações internas e externas aos setores considerados no desenvolvimento destas variações.

Baseado em Guilhoto et al. (1996), o cálculo dos índices puros de ligação iniciase pela definição de uma matriz A, que contém os coeficientes de insumos diretos do setor destacado $j$ e o resto da economia:

$$
A=\left[\begin{array}{cc}
A_{\mathrm{jj}} & A_{\mathrm{jr}} \\
A_{\mathrm{rj}} & A_{\mathrm{rr}}
\end{array}\right]
$$

onde $\mathrm{A}_{\mathrm{jj}}$ e $\mathrm{A}_{\mathrm{rr}}$ são respectivamente matrizes que representam insumos diretos do setor $j$ e do resto da economia; $\mathrm{A}_{\mathrm{rj}}$ e $\mathrm{A}_{\mathrm{jr}}$ representam matrizes dos insumos diretos comprados pelo setor $j$ do resto da economia e os insumos diretos comprados pelo resto da economia do setor $j$. 
A matriz inversa de Leontief $(L)$, quando considerada a matriz A definida acima, é dada por:

$$
\mathbf{L}=(\mathbf{I}-\mathbf{A})^{-1}=\left[\begin{array}{ll}
\mathbf{L}_{j j} & \mathbf{L}_{j r} \\
\mathbf{L}_{r j} & \mathbf{L}_{r r}
\end{array}\right]=\left[\begin{array}{cc}
\Delta_{j j} & 0 \\
0 & \Delta_{r r}
\end{array}\right]\left[\begin{array}{cc}
\Delta_{j} & 0 \\
0 & \Delta_{r}
\end{array}\right]\left[\begin{array}{cc}
\mathbf{I} & \mathbf{A}_{j r} \Delta_{r} \\
\mathbf{A}_{r j} & \mathbf{I}
\end{array}\right]
$$

onde seus elementos são representados por:

$$
\begin{gathered}
\Delta_{j}=\left(\mathbf{I}-\mathbf{A}_{j j}\right)^{-1}, \\
\Delta_{r}=\left(\mathbf{I}-\mathbf{A}_{r r}\right)^{-1}, \\
\Delta_{j j}=\left(\mathbf{I}-\Delta_{j} \mathbf{A}_{j r} \Delta_{r} \mathbf{A}_{r j}\right)^{-1}, \\
\Delta_{r r}=\left(\mathbf{I}-\Delta_{r} \mathbf{A}_{r j} \Delta_{j} \mathbf{A}_{j r}\right)^{-1} .
\end{gathered}
$$

A partir da matriz calculada em (15), pode-se calcular:

$$
X=(I-A)^{-1} Y
$$

e derivar um conjunto de índices que podem ser usados para ordenar os setores tanto em termos de sua importância no valor da produção gerado quanto para verificar como ocorre o processo de produção na economia. Desenvolvendo a equação (20), pode-se obter:

$$
\left(\begin{array}{l}
\mathbf{X}_{j} \\
\mathbf{X}_{i}
\end{array}\right)=\left(\begin{array}{cc}
\Delta_{j j} & 0 \\
0 & \Delta_{r r}
\end{array}\right)\left(\begin{array}{cc}
\Delta_{j} & 0 \\
0 & \Delta_{r}
\end{array}\right)\left(\begin{array}{cc}
\mathbf{I} & \mathbf{A}_{j r} \Delta_{r} \\
\mathbf{A}_{r j} \Delta_{j} & \mathbf{I}
\end{array}\right)\left(\begin{array}{l}
\mathbf{Y}_{j} \\
\mathbf{Y}_{r}
\end{array}\right)
$$

Realizando a multiplicação do lado esquerdo da equação, obtém-se:

$$
\left(\begin{array}{l}
\mathbf{X}_{j} \\
\mathbf{X}_{r}
\end{array}\right)=\left(\begin{array}{cc}
\Delta_{j j} & 0 \\
0 & \Delta_{r r}
\end{array}\right)\left(\begin{array}{c}
\Delta_{j} \mathbf{Y}_{j}+\Delta_{j} \mathbf{A}_{j r} \Delta_{r} \mathbf{Y}_{r} \\
\Delta_{r} \mathbf{A}_{r j} \Delta_{j} \mathbf{Y}_{j}+\Delta_{r} \mathbf{Y}_{r}
\end{array}\right)
$$

O índice puro de ligação para trás $(P B L)$ e o índice puro de ligação para frente $(P F L)$ são, pois, dados por:

$$
\begin{gathered}
P B L=\Delta_{r} \mathbf{A}_{r j} \mathbf{Y}_{j}, \\
P F L=\Delta_{j} \mathbf{A}_{j r} \Delta_{r} \mathbf{Y}_{r},
\end{gathered}
$$


$\mathrm{O}$ índice puro de ligação para trás representa o impacto do valor da produção total do setor $j$ sobre o resto da economia, livre da demanda de insumos próprios e dos retornos do resto da economia para o setor. Por sua vez, o índice puro de ligação para frente representa o impacto do valor da produção total do resto da economia sobre o setor $j$. O índice puro total das ligações é a soma dos dois índices, expressos em valores correntes:

$$
P T L=P B L+P F L
$$

Pode-se calcular também os índices puros de ligações normalizados, dividindose os índices puros pelo seu valor médio. O índice puro de ligação normalizado para trás é representado por $P B L N$ :

$$
P B L N=\frac{P B L}{P B L m}
$$

onde: PBLm representa a média dos índices puros de ligação de todos os setores, dada por:

$$
P B L m=\frac{\sum_{i=1}^{n} P B L_{i}}{n}
$$

Procedimento análogo é realizado para calcular o índice puro normalizado para frente $(P F L N)$ e o índice puro total de ligação normalizado (PTLN). 


\subsubsection{Multiplicadores}

O cálculo dos multiplicadores permite analisar o impacto de uma variação na demanda final de determinado setor sobre a variável econômica de interesse (produção, renda, emprego). Os multiplicadores a serem determinados podem ser do tipo I ou II, os multiplicadores de produção do tipo I permitem avaliar o aumento de produção de determinado setor para satisfazer uma unidade adicional de sua demanda final, considerando como exógeno o consumo das famílias. O multiplicador do tipo II é calculado incluindo-se a endogeneização do consumo das famílias. Neste caso, para o cálculo dos multiplicadores tipo II, a matriz $Z$ (transações intersetoriais) incorpora uma linha e uma coluna adicionais correspondentes à remuneração das famílias e o consumo doméstico (Miller \& Blair, 1985).

O resultado final da endogeneização do consumo das famílias é que os multiplicadores do tipo II incluem efeitos diretos (sobre o próprio setor), indiretos (sobre os demais setores) e induzidos (via consumo endogeneizado) de um aumento unitário na demanda final do setor que se deseja avaliar o impacto sobre a economia.

\subsubsection{Multiplicadores de produção}

Dado que $L=(I-A)^{-1}$, o multiplicador setorial de produção do setor $j$ será:

$$
M P_{j}=\sum_{i=1}^{n} l_{i j}, \quad j=1, \ldots, n
$$

Onde: $\mathrm{MP}_{\mathrm{j}}$ é o multiplicador de produção do tipo I e $\mathrm{l}_{\mathrm{ij}}$ é um elemento da matriz inversa de Leontief.

O valor calculado representa o valor total de produção de toda a economia que é acionado para atender a variação de uma unidade na demanda final do setor $j$. 
Para o multiplicador tipo II, calcula-se a matriz inversa de Leontief $\bar{L}=(I-\bar{A})^{-1}$, que é obtida a partir de uma matriz $\bar{A}$ de coeficientes técnicos, onde o consumo das famílias é endogeneizado. Com esta $\bar{L}$ obtém-se os seguintes multiplicadores setoriais do tipo II:

$$
M \bar{P}_{j}=\sum_{i=1}^{n} \bar{l}_{i j}, \quad j=1, \ldots, n
$$

Onde: $M \bar{P}_{j}$ é o multiplicador de produção do tipo II e $\bar{l}_{i j}$ é um elemento qualquer da matriz $\bar{L}$.

Em tal contexto, os gastos com consumo constituem o principal elemento da demanda final. É de se pontuar que tais multiplicadores de produção apoiam-se sobre uma participação das famílias no consumo, participação esta que depende do que é produzido em cada setor. Esse raciocínio significa tornar o modelo fechado em relação às famílias.

\subsubsection{Multiplicadores de emprego}

Especificamente sobre o emprego, os multiplicadores do tipo I fornecem o número de postos de trabalho gerados na economia para cada posto gerado no setor de interesse, incorporando efeitos direto e indireto. Em paralelo, os multiplicadores de emprego tipo II fornecem o número de empregos gerados na economia para cada posto de trabalho no setor, incluindo efeitos direto, indireto e induzido.

Desta forma, pode-se expressar o multiplicador de emprego tipo I como:

$$
M E_{j}=\sum_{i=1}^{n}\left(w_{n+1, i} \cdot l_{i j}\right) / w_{n+1, j}
$$

Onde: $\mathrm{ME}_{\mathrm{j}}$ é o multiplicador de empregos tipo $\mathrm{I} ; \mathrm{W}_{\mathrm{n}+1}$ é o coeficiente de empregos por unidade monetária produzida e $\mathrm{l}_{\mathrm{ij}}$ é um elemento da matriz inversa de Leontief. 
O multiplicador de emprego tipo II representa os efeitos diretos, indiretos e induzidos de uma variação na demanda final do setor sobre a geração de postos de trabalho, medido em pessoas empregadas por posto de trabalho do setor $\mathrm{j}$. A expressão do multiplicador de emprego é dada por:

$$
M \bar{E}_{j}=\sum_{i=1}^{n}\left(w_{n+1, i} \bar{l}_{i j}\right) / w_{n+1, j}
$$

Onde: $M \bar{E}_{j}$ é o multiplicador de emprego tipo II, $\mathrm{w}_{\mathrm{n}+1}$ é o coeficiente de trabalho físico (número de empregos por unidade monetária produzida) e $\bar{l}_{i j}$ origina-se da matriz $\bar{L}=(I-\bar{A})^{-1}$.

\subsubsection{Multiplicadores de renda}

De forma análoga ao multiplicador de produção, o multiplicador de renda tipo I representa a renda gerada por todos os setores para cada unidade monetária de renda do setor $j$ obtida devido ao aumento de produção desta indústria necessário para atender a variação de uma unidade em sua demanda final. O multiplicador tipo I inclui efeitos direto e indireto. Algebricamente, tem-se:

$$
M Y_{j}=\sum_{i=1}^{n}\left(y_{n+1, i} l_{i j}\right) / y_{n+1, j}
$$

Onde: $\mathrm{MY}_{\mathrm{j}}$ é o multiplicador de renda do tipo $\mathrm{I}, \mathrm{y}_{\mathrm{n}+1}$ é o coeficiente da renda por unidade monetária produzida e $1_{\mathrm{ij}}$ é um elemento da matriz inversa de Leontief.

O multiplicador de renda tipo II é determinado como:

$$
M \bar{Y}_{j}=\sum_{i=1}^{n}\left(y_{n+1, i} \bar{l}_{i j}\right) / y_{n+1, j}
$$

Onde: $M \bar{Y}_{j}$ é o multiplicador de renda tipo II, $\mathrm{y}_{\mathrm{n}+1}$ é o coeficiente da renda por unidade monetária produzida e $\bar{l}_{i j}$ origina-se da matriz $\bar{L}=(I-\bar{A})^{-1}$ (matriz de Leontief com consumo das famílias endogeneizado). Portanto, o multiplicador de renda tipo II incorpora efeitos direto, indireto e induzido sobre a economia. 


\subsubsection{Multiplicador de impostos}

O multiplicador de impostos podem ser calculados de forma análoga aos multiplicadores de renda tipo I e II, bastando substituir o coeficiente de renda pelo coeficiente de imposto por unidade de produção nas equações (38) e (39), mantendo-se os outros membros das equações.

\subsubsection{Produto Interno Bruto setorial}

A técnica de insumo-produto foi desenvolvida visando analisar as relações entre os setores produtivos e de consumo de uma economia nacional, permitindo uma análise sistêmica e integrada do fluxo do produto. Seguindo a proposta de Furtuoso et al., (1998) e detalhada em Guilhoto et al. (2000), o procedimento adotado para a estimativa do PIB setorial utiliza as informações disponíveis nas Tabelas de insumo-produto referentes aos valores adquiridos pelos supermercados (produtos e serviços).

A cadeia de produção e distribuição de produtos e serviços na qual os Supermercados participam como elo final será dividida em três setores:

a) Fornecedores de produtos,

b) Setor supermercadista e

c) Serviços. O primeiro agregado de atividades é constituído pela Agropecuária e extrativismo e por indústrias fornecedoras de produtos. O segundo agregado é o próprio setor, estimando-se sua contribuição para o PIB da cadeia e o terceiro agregado de atividades compreendem as atividades de serviços prestados à cadeia.

O Valor Adicionado a preços de mercado é obtido pela soma do valor adicionado a preços básicos aos impostos indiretos líquidos, subsídios sobre produtos e subtração da dummy financeira, resultando na seguinte expressão:

$$
V A_{P M}=V A_{P B}+I I L-D u F
$$


Onde:

$V A_{P M}=$ Valor adicionado a preços de mercado

$V A_{P B}=$ Valor adicionado a preços básicos

$I I L=$ Impostos indiretos líquidos

$D u F=$ Dummy financeira

O cálculo do PIB do Agregado I (Fornecedores de produtos) são utilizadas as informações disponíveis nas Tabelas de insumo-produto referentes aos valores dos insumos adquiridos pelo setor supermercadista. As colunas com os valores dos insumos são multiplicadas pelos respectivos coeficientes de valor adicionado $\left(C V A_{i}\right)$. Para obter os Coeficientes do Valor Adicionado por setor $\left(C V A_{i}\right)$ divide-se o Valor Adicionado a Preços Básicos $\left(V A_{P M I}\right)$ pela Produção do Setor $\left(X_{i}\right)$, ou seja:

$$
C V A_{i}=\frac{V A_{P M i}}{X_{i}}
$$

Portanto, o problema de dupla contagem existente em outras metodologias desenvolvidas para estimar o Produto Interno Bruto setorial foi eliminado, assim tem-se:

$$
P I B_{I}=\sum_{i=1}^{n} z_{i} \times C V A_{i}
$$

Onde:

$P I B_{I}=$ Produto Interno Bruto do Agregado I,

$i=1,2, \ldots, 33$ (setores do modelo de insumo-produto fornecedores de produtos), $z_{i}=$ valor total do insumo do setor i destinado ao setor supermercadista, $C V A_{i}=$ coeficiente do valor adicionado do setor $i$. 
Para o Agregado II (próprio setor supermercadista) considera-se no cálculo o valor adicionado gerado pelos Supermercados e são subtraídos os valores que foram utilizados como insumos, desta forma, mais uma vez elimina-se o problema de dupla contagem presente em estimativas do PIB setorial. Temos que:

$$
P I B_{I I}=V A_{P M}-\sum_{i=1}^{n} z_{i} \times C V A_{i}
$$

Onde:

$P I B_{I I}=$ Produto Interno Bruto do Agregado II, $i=1,2, \ldots, 43$ (setores do modelo de insumo-produto), $z_{i}=$ valor total do insumo do setor i destinado ao setor supermercadista, $C V A_{i}=$ coeficiente do valor adicionado do setor $i$.

O Agregado III compreende os setores de Transportes, Comércio (exceto Supermercados) e Serviços. Levando-se em consideração que o setor supermercadista é o elo final junto ao consumidor, estes setores fornecem serviços à cadeia produtiva. $\mathrm{O}$ tratamento dado para este conjunto de setores é determinar a participação da demanda final do setor supermercadista na demanda final global (coeficiente) e multiplicar o coeficiente pelo total do valor agregado dos serviços excluídos os Supermercados:

$$
P I B_{I I I}=\sum_{i=1}^{n} V A_{i} \times \frac{D F_{S}}{D F G}
$$

Onde:

$P I B_{I I I}=$ Produto Interno Bruto do Agregado III,

$i=1,2, \ldots, 9$ (setores do modelo de insumo-produto fornecedores serviços), $V A_{i}=$ valor agregado dos setores de serviços, excluindo supermercados, $D F s=$ demanda final dos supermercados, $D F G=$ demanda final global da economia. 
O PIB setorial dos Supermercados é dado por:

$$
P I B_{\text {Supermercados }}=P I B_{I}+P I B_{I I}+P I B_{I I I}
$$

Pode-se mensurar o pessoal ocupado na produção dos bens e serviços utilizados na cadeia produtiva que inclui o setor supermercadista como o elo final. Procedimento similar ao cálculo do Produto Interno Bruto setorial, para o agregado I:

$$
P O_{I}=\sum_{i=1}^{n} z_{i} \times C P O_{i}
$$

Onde:

$P O=$ Pessoal ocupado em cada Agregado de atividades (I, II e III), $i=1,2, \ldots, 33$ setores fornecedores de produtos,

$z_{i}=$ valor total do insumo do setor i destinado ao setor supermercadista, $C P O_{i}=$ coeficiente do pessoal ocupado do setor $i$.

Para obter os Coeficientes do Pessoal Ocupado por setor $\left(\mathrm{CPO}_{i}\right)$ divide-se o Número de pessoas ocupadas no setor i $\left(P O_{i}\right)$ pela Produção do Setor i $\left(X_{i}\right)$, ou seja:

$$
C P O_{i}=\frac{P O_{i}}{X_{i}}
$$

Para o setor de supermercados, é contabilizado o total de postos de trabalho, temos assim $\mathrm{PO}_{\mathrm{II}}$. $\mathrm{O}$ número de postos de trabalho gerados nos setores de serviços é calculado de forma similar ao valor agregado:

$$
P O_{I I I}=\sum_{i=1}^{n} P O_{i} \times \frac{D F_{S}}{D F G}
$$


Onde:

$P O_{I I I}=$ Pessoal Ocupado do Agregado III,

$i=1,2, \ldots, 9$ (setores do modelo de insumo-produto fornecedores serviços),

$V A_{i}=$ valor agregado dos setores de serviços, excluindo supermercados,

$D F s=$ demanda final dos supermercados,

$D F G=$ demanda final global da economia.

O número total de postos de trabalho da cadeia é calculado como sendo:

$$
P O_{\text {Supermercados }}=P O_{I}+P O_{I I}+P O_{I I I}
$$

Utilizando os resultados do PIB dos Agregados e número de pessoas ocupadas pode-se calcular a produtividade do trabalho:

$$
P T_{A}=\frac{P I B_{A}}{P O_{A}}
$$

Onde:

$P T_{A}=$ Produtividade do trabalho no Agregado A (I, II e III),

$P I B_{A}=$ Produto Interno Bruto no Agregado A,

$P O_{A}=$ Pessoal ocupado no Agregado A.

\subsection{Desagregação do setor supermercadista}

O setor 34-Comércio, presente na matriz de insumo-produto do Brasil, engloba as atividades de atacado e varejo, incluindo ampla gama de negócios. Fazem parte desse setor as lojas pertencentes ao setor supermercadista, definidas anteriormente na Tabela 1. Para realizar a análise setorial dos supermercados utilizando indicadores econômicos da teoria insumo-produto, tornou-se necessário desagregar o setor 35-Supermercados do setor original 34-Comércio dentro da matriz de insumo-produto nacional dos anos de 1990, 1995 e 1999. Os dados para realizar essa desagregação foram obtidos em

publicações do Instituto Brasileiro de Geografia e Estatística (IBGE), denominadas 
Pesquisa Anual do Comércio dos anos de 1990, 1995, 1997 e 1999. Para o ano de 1995, foram utilizados dados das publicações de 1995 e 1997, pois as pesquisas dos anos anteriores não traziam detalhes de alguns custos operacionais importantes dos supermercados. Também foram coletados dados junto à Associação Brasileira de Supermercados (ABRAS) e em suas publicações (revista SuperHiper, maio de 2001), completando o banco de dados necessário para a desagregação. É importante observar que a matriz de 1999 foi estimada por metodologia proposta apresentada em Guilhoto \& Sesso Filho (2002).

O setor supermercadista foi desagregado nas duas matrizes que originam a matriz de insumo-produto: Matriz de Uso e Matriz de Produção. Os critérios para desagregação do setor 35-Supermercados dentro da Matriz de Uso constam do Anexo A, os quais se referem aos itens da Pesquisa Anual do Comércio e a dados coletados junto à ABRAS, que foram utilizados para estabelecer os valores destinados aos supermercados. Para a Matriz de Produção, foi estabelecido o critério de que o setor 35-Supermercados produz exclusivamente dois produtos: Margem de Comercialização e Serviços Prestados às Famílias. Essa definição foi baseada na natureza da atividade varejista, dado que o setor supermercadista constitui uma atividade de prestação de serviços, distribuindo produtos para o consumidor final e, em muitos casos, beneficiando e transformando bens. Pode-se citar os itens comercializados na padaria, confeitaria e no açougue, bens para os quais o varejista adiciona valor com o processamento, porém, sem pagar o Imposto sobre Produtos Industrializados (IPI), constituindo uma prestação de serviços.

\subsubsection{Nova proposta metodológica}

O setor 34-Comércio na metodologia das Contas Nacionais é considerado uma atividade constituída de intermediários, os quais simplesmente repassam seus produtos na exata forma que os receberam, auferindo sua margem de comercialização. A limitação dessa abordagem é calcular os indicadores econômicos baseados na teoria insumo-produto em valores que correspondem a um aumento de produção em termos de Margem de Comércio, não levando em consideração os efeitos secundários da aquisição dos produtos comercializados, mas apenas os custos operacionais básicos do comércio. 
Para analisar em profundidade a influência do setor supermercadista na economia brasileira, foi desenvolvida uma nova proposta de análise, incorporando os valores das mercadorias comercializadas pelos supermercados em seus custos operacionais.

Os valores a preços de consumidor foram obtidos junto à Associação Brasileira de Supermercados (SuperHiper, maio de 2001) e em conjunto com dados da própria matriz de insumo-produto foram obtidos os valores a preços básicos, impostos e margens de transporte e comercialização dos produtos comercializados pelo setor supermercadista no ano de 1999. Estes valores foram subtraídos do componente Consumo das Famílias e alocados para o setor 34-Supermercados, já desagregado pela metodologia descrita anteriormente, dentro da Matriz de Uso. Foi definido que o setor supermercadista vende seus produtos e serviços diretamente ao consumidor final. Portanto, o valor que é adicionado aos custos operacionais referentes ao montante total de produtos a preços básicos, impostos e margem de comercialização e transporte também foi somado ao valor da produção vendida ao Consumo das Famílias.

Obtida a Matriz de Uso, a Matriz de Produção incorpora a margem de comercialização necessária para o pagamento dos valores alocados para o setor supermercadista, o qual destina seu produto (margem de comércio) para o Consumo das Famílias. O valor dos Serviços Prestados às Famílias é mantido inalterado.

A aplicação da nova proposta metodológica para o ano de 1995 foi realizada obtendo-se os valores a preços de consumidor das mercadorias comercializadas pelos supermercados calculados utilizando-se taxas de crescimento da produção no período 1995/99. Inicialmente, foram calculadas as participações dos supermercados na comercialização de cada grupo de produtos para o ano de 1999 (abrangidos pelas Contas Nacionais), e estas foram utilizadas para calcular sua participação na comercialização dos mesmos em 1995, mas considerando os decréscimos determinados pela menor produção dos bens daquele ano. O resultado final da aplicação da nova proposta metodológica se encontra no Anexo, que traz as Matrizes de insumo-produto para os anos de 1990, 1995 e 1999, elaboradas utilizando as duas metodologias. 
Para o ano de 1990, a desagregação foi realizada pela metodologia denominada tradicional, não sendo possível a aplicação da nova proposta metodológica devido à falta de dados confiáveis. Isto ocorre porque a automação comercial que se intensificou a partir de 1995, como foi analisado anteriormente, proporcionou maior volume de dados sobre as vendas e custos operacionais dos supermercados. Antes do período 1995/99, havia grande dificuldade para o levantamento de dados sobre o setor, principalmente de valores associados à participação no faturamento bruto das diversas categorias de produtos comercializados pelo setor, informações necessárias para a aplicação da nova metodologia proposta na pesquisa. A maior facilidade da coleta de dados pelas empresas permitiu à Associação Brasileira de Supermercados e a suas consultorias contratadas levantar e acompanhar a evolução dos números do setor a partir de 1995, tais como número de lojas, participação das diversas categorias de produtos, número de funcionários, evolução das vendas em cada região do país, faturamento por loja e outras informações.

Para diferenciar os resultados dos indicadores econômicos calculados a partir das matrizes elaboradas utilizando as duas metodologias, foi adicionada a letra "n" (nova metodologia) após o ano para o qual foram obtidos os indicadores. Além disso, a metodologia baseada em critérios das Contas Nacionais foi denominada "metodologia tradicional" e a nova metodologia de "nova proposta metodológica".

\subsubsection{Valores a preços básicos das mercadorias comercializadas pelos supermercados}

Os valores a preços básicos das mercadorias comercializadas pelos supermercados, assim como os impostos referentes ao processo de comercialização nos anos 1995 e 1999, foram calculados utilizando-se informações obtidas junto à Associação Brasileira de Supermercados (ABRAS) e das próprias matrizes de insumoproduto. Os valores a preços básicos das mercadorias foram extraídos de publicações da ABRAS (revista SuperHiper) e as alíquotas de impostos, margens de comércio e transporte foram calculadas a partir dos dados da matriz de insumo-produto, tornando possível o cálculo dos valores a preços básicos das mercadorias. Os resultados se 
encontram na Tabela 21, na qual observa-se que o setor supermercadista tem grande participação no consumo das famílias, principalmente de produtos alimentícios. É importante lembrar que esta participação é sobre o consumo total das famílias, incluindo todos os produtos consumidos. As porcentagens foram calculadas a partir dos valores a preços básicos, excluindo impostos e margens que podem ter participação significativa no preço final do produto (preço de mercado).

Para alguns produtos, como Leite beneficiado e Outros laticínios, os supermercados são o principal equipamento de comercialização, cujas participações no consumo das famílias cresceram no período 1995/1999. O setor supermercadista ainda possui participação pouco significativa na comercialização de Equipamentos eletrônicos e Vestuário.

Os valores dos impostos e margens são relativos ao processo de compra e distribuição dos produtos comercializados pelos supermercados. No caso do ICMS, por exemplo, são valores englobados nos preços dos produtos adquiridos pelos supermercados antes de serem vendidos ao consumidor final. Observando o valor do Consumo intermediário, relativo às vendas dos supermercados no consumo final das famílias, constata-se que esta é de $8 \%$ aproximadamente, ou seja, a participação do setor supermercadista nos gastos totais da população.

Os valores referentes aos preços básicos, impostos e margens calculadas foram subtraídos do componente Consumo das Famílias da Matriz de Recursos e Usos, e alocados internamente no Consumo Intermediário do setor 35-Supermercados que foi anteriormente desagregado. $\mathrm{O}$ valor total mencionado na Tabela 21 (Consumo intermediário) foi adicionado no produto Margem dos Supermercados, anteriormente incluído na Matriz de Usos e também na Matriz de Produção. O Quadro 4 ilustra a realocação dos valores calculados. 
Tabela 21. Valores a preços básicos dos produtos comercializados pelos supermercados, margens e impostos em $\mathrm{R}$ \$ milhões nominais e participação no Consumo das Famílias da Matriz de Recursos e Usos (\%).

\begin{tabular}{|c|c|c|c|c|}
\hline \multirow{2}{*}{ Produto } & \multicolumn{4}{|c|}{ Valores totais e participação (\%) } \\
\hline & 1995 & $\%$ & 1999 & $\%$ \\
\hline Outros produtos agropecuários & 1.828 & $10 \%$ & 3.167 & $13 \%$ \\
\hline Produtos minerais não-metálicos & 91 & $14 \%$ & 214 & $19 \%$ \\
\hline Produtos metalúrgicos não-ferrosos & 44 & $23 \%$ & 92 & $22 \%$ \\
\hline Outros produtos metalúrgicos & 182 & $15 \%$ & 365 & $17 \%$ \\
\hline Material elétrico & 639 & $18 \%$ & 896 & $18 \%$ \\
\hline Equipamentos eletrônicos & 942 & $14 \%$ & 845 & $20 \%$ \\
\hline Papel, celulose, papelão e artefatos & 1.223 & $47 \%$ & 2.255 & $50 \%$ \\
\hline Outros produtos químicos & 100 & $17 \%$ & 128 & $16 \%$ \\
\hline Produtos farmacêuticos e de perfumaria & 3.319 & $36 \%$ & 3.844 & $26 \%$ \\
\hline Artigos de plástico & 102 & $19 \%$ & 175 & $22 \%$ \\
\hline Outros produtos têxteis & 129 & $5 \%$ & 223 & $6 \%$ \\
\hline Artigos do vestuário & 376 & $4 \%$ & 664 & $7 \%$ \\
\hline Produtos de couro e calçados & 68 & $3 \%$ & 175 & $7 \%$ \\
\hline Produtos do café & 661 & $29 \%$ & 1.162 & $33 \%$ \\
\hline Arroz beneficiado & 566 & $37 \%$ & 877 & $35 \%$ \\
\hline Farinha de trigo & 66 & $41 \%$ & 152 & $36 \%$ \\
\hline Outros produtos vegetais beneficiados & 2.993 & $31 \%$ & 5.094 & $35 \%$ \\
\hline Carne bovina & 1.719 & $21 \%$ & 2.962 & $21 \%$ \\
\hline Carne de aves abatidas & 1.081 & $27 \%$ & 1.420 & $21 \%$ \\
\hline Leite beneficiado & 1.173 & $43 \%$ & 2.024 & $57 \%$ \\
\hline Outros laticínios & 1.794 & $50 \%$ & 2.787 & $57 \%$ \\
\hline Açúcar & 324 & $31 \%$ & 702 & $38 \%$ \\
\hline Óleos vegetais refinados & 1.123 & $38 \%$ & 1.662 & $33 \%$ \\
\hline Outros produtos alimentares & 3.243 & $34 \%$ & 5.158 & $34 \%$ \\
\hline Bebidas & 2.055 & $39 \%$ & 3.300 & $48 \%$ \\
\hline Produtos diversos & 449 & $14 \%$ & 847 & $17 \%$ \\
\hline Margem de comércio & 122 & $0,3 \%$ & 148 & $0,4 \%$ \\
\hline Margem de transporte & 708 & $5 \%$ & 1.072 & $4 \%$ \\
\hline Produto importado & 1.383 & $10 \%$ & 4.236 & $15 \%$ \\
\hline Imposto de importação & 99 & $5 \%$ & 356 & $17 \%$ \\
\hline ICMS Nacional & 2.336 & $10 \%$ & 1.837 & $7 \%$ \\
\hline ICMS Importado* & 117 & $10 \%$ & - & - \\
\hline IPI Nacional & 1.324 & $22 \%$ & 1.597 & $22 \%$ \\
\hline IPI Importado* & 152 & $16 \%$ & - & - \\
\hline Outros impostos indiretos líquidos nacionais & 81 & $5 \%$ & 84 & $4 \%$ \\
\hline Outros impostos indiretos líquidos importados* & 25 & $14 \%$ & - & - \\
\hline Consumo intermediário & 32.636 & $8 \%$ & 50.521 & $8 \%$ \\
\hline
\end{tabular}

Fonte: dados da pesquisa.

* para o ano de 1999, os valores dos produtos importados estão somados aos valores nacionais. 
Observando o Quadro 4, notam-se os componentes modificados pela realocação dos valores das mercadorias comercializadas pelos supermercados (em negrito): $\mathrm{z}_{12}, \mathrm{C}_{1}$, $\mathrm{C}_{2}$ e $\mathrm{X}_{2}$. Os preços básicos das mercadorias presentes em $\mathrm{C}_{1}$ (Consumo) são subtraídos deste componente e adicionados em $\mathrm{z}_{12}$ (Demanda dos Supermercados) e o valor total das mercadorias adicionado em $\mathrm{C}_{2}$ (Demanda das famílias por Margem dos Supermercados). Além disso, as importações e tributos são subtraídos de IMC (importações consumidas pelas famílias) e de NC (tributos pagos pelas famílias) e, posteriormente, adicionados respectivamente em $\mathrm{IM}_{2}$ (importações consumidas pelos Supermercados) e $\mathrm{N}_{2}$ (tributos pagos pelos Supermercados). Obviamente, os somatórios da demanda total, subtotal do consumo do setor Supermercados e o Valor Agregado dos Supermercados também serão modificados.

O resultado final é um sistema econômico no qual o setor Supermercados atua como uma indústria, adquirindo produtos e vendendo serviços de distribuição para as famílias (Consumo das famílias), as quais pagam a este uma margem de comercialização (Margem dos Supermercados) que lhe permite arcar com os custos de aquisição e distribuição dos bens, incluindo impostos, transporte, mão-de-obra e operações internas das empresas.

Deve-se observar que o Valor bruto da produção aumenta no mesmo montante do valor total adicionado no item Margem dos Supermercados, que passa a ser um novo produto dentro da economia. A nova Matriz insumo-produto, de acordo com a nova metodologia de tratamento do setor Supermercados, permitirá analisar mais eficientemente a participação deste na economia, como um intermediário na aquisição de bens da população e impactos nos setores direta e indiretamente relacionados. 


\begin{tabular}{|c|c|c|c|c|c|c|c|c|c|c|}
\hline \multirow{3}{*}{\multicolumn{2}{|c|}{$\begin{array}{c}\text { Matriz de } \\
\text { Recursos e Usos }\end{array}$}} & \multicolumn{8}{|c|}{ Setores compradores $(\mathrm{j})$} & \multirow{3}{*}{$\begin{array}{l}\text { Demanda } \\
\text { total }\end{array}$} \\
\hline & & \multicolumn{3}{|c|}{ Demanda Intermediária } & \multicolumn{5}{|c|}{ Demanda final } & \\
\hline & & $\begin{array}{l}\text { Outros } \\
\text { setores }\end{array}$ & $\begin{array}{c}\text { Setor } \\
\text { Supermer- } \\
\text { cados }\end{array}$ & $\begin{array}{c}\text { Demanda } \\
\text { Interme- } \\
\text { diária } \\
\end{array}$ & $\begin{array}{c}\text { Con- } \\
\text { sumo } \\
\text { famílias }\end{array}$ & $\begin{array}{l}\text { Inves- } \\
\text { timento }\end{array}$ & $\begin{array}{l}\text { Gasto do } \\
\text { Governo }\end{array}$ & $\begin{array}{l}\text { Expor- } \\
\text { tações }\end{array}$ & $\begin{array}{c}\text { Demanda } \\
\text { final }\end{array}$ & \\
\hline \multirow{2}{*}{$\begin{array}{c}\text { Produtos } \\
\text { e } \\
\text { serviços }\end{array}$} & $\begin{array}{l}\text { Outros } \\
\text { produtos } \\
\text { e serviços }\end{array}$ & $\mathrm{z}_{11}$ & $\mathbf{z}_{12}$ & $\sum_{j=1}^{n} Z_{1 j}$ & $\mathbf{C}_{1}$ & $\mathrm{I}_{1}$ & $\mathrm{G}_{1}$ & $\mathrm{E}_{1}$ & $\mathrm{Y}_{1}$ & $\mathrm{X}_{1}$ \\
\hline & $\begin{array}{l}\text { Margem } \\
\text { dos } \\
\text { supermer } \\
\text { cados } \\
\end{array}$ & $z_{21}$ & $\mathrm{z}_{22}$ & $\sum_{j=1}^{n} Z_{2 j}$ & $\mathbf{C}_{2}$ & $\mathrm{I}_{2}$ & $\mathrm{G}_{2}$ & $\mathrm{E}_{2}$ & $\mathrm{Y}_{2}$ & $\mathbf{X}_{2}$ \\
\hline \multicolumn{2}{|c|}{ Subtotal } & $\sum_{i=1}^{n} Z_{i 1}$ & $\sum_{i=1}^{n} Z_{i 2}$ & $\sum_{i, j=1}^{n} Z_{i j}$ & $\sum_{i=1}^{n} C_{i}$ & $\sum_{i=1}^{n} I_{i}$ & $\sum_{i=1}^{n} G_{i}$ & $\sum_{i=1}^{n} E_{i}$ & $\sum_{i=1}^{n} Y_{i}$ & $\sum_{i=1}^{n} X_{i}$ \\
\hline \multicolumn{2}{|c|}{ Importações } & $\mathrm{IM}_{1}$ & $\mathbf{I M}_{2}$ & $\sum_{j=1}^{n} I M_{j}^{D I}$ & IMC & IMI & IMG & IME & $\mathrm{IM}^{\mathrm{Y}}$ & \\
\hline \multicolumn{2}{|c|}{ Tributos } & $\mathrm{N}_{1}$ & $\mathbf{N}_{2}$ & $\sum_{j=1}^{n} N_{j}$ & NC & NI & NG & $\mathrm{NE}$ & $\mathrm{N}^{\mathrm{Y}}$ & \\
\hline \multicolumn{2}{|c|}{ Salários } & $\mathrm{L}_{1}$ & $\mathrm{~L}_{2}$ & $\sum_{j=1}^{n} L_{j}$ & & & & & & \\
\hline \multicolumn{2}{|c|}{ Valor adicionado } & $\mathrm{VA}_{1}$ & $\mathbf{V A}_{2}$ & $\sum_{j=1}^{n} V A_{j}$ & & & & & & \\
\hline \multicolumn{2}{|c|}{$\begin{array}{l}\text { Valor bruto da } \\
\text { produçã̃o }\end{array}$} & $\mathrm{X}_{1}$ & $\mathrm{X}_{2}$ & $\sum_{j=1}^{n} X_{j}$ & & & & & & \\
\hline
\end{tabular}

Quadro 4 - Realocação dos valores a preços básicos, impostos e margens das mercadorias comercializadas pelos supermercados dentro da Matriz de Recursos e Usos.

Fonte: elaborado pelo autor. 


\subsubsection{Deflacionamento de valores dos setores da matriz de insumo-produto}

O cálculo de multiplicadores e do Produto Interno Bruto setorial necessita que seja realizado o deflacionamento de valores monetários a fim de que os resultados possam ser comparados. A Tabela 22 apresenta os deflatores implícitos setoriais disponibilizados pelo Instituto Brasileiro de Geografia e Estatística (IBGE) para atualização dos valores das Matrizes de Insumo-produto dos anos de 1990, 1995 e 1999. O deflacionamento é realizado multiplicando-se o valor monetário referente a determinado setor por 1/deflator, obtendo-se o valor atualizado para o ano de 1999 . Portanto, os deflatores setoriais para este ano são iguais a um.

Nota-se que os deflatores diferem significativamente entre os setores, portanto, a comparação dos resultados sem a realização do deflacionamento levaria a conclusões distantes da realidade. Os resultados da pesquisa são apresentados em valores deflacionados para o ano de 1999. 
Tabela 22. Deflatores implícitos setoriais da Matriz de Insumo-produto para os anos de 1990, 1995 e 1999.

\begin{tabular}{|c|c|c|c|c|}
\hline \multirow{2}{*}{\multicolumn{2}{|c|}{ Setores }} & \multicolumn{3}{|c|}{ Deflator } \\
\hline & & \multirow{2}{*}{$\begin{array}{r}1990 \\
0,0408\end{array}$} & \multirow{2}{*}{$\begin{array}{r}1995 \\
0,8143\end{array}$} & \multirow{2}{*}{$\begin{array}{c}1999 \\
1\end{array}$} \\
\hline 1 & Agropecuária & & & \\
\hline 2 & Extrativa Mineral & 0,0395 & 0,5686 & 1 \\
\hline 3 & Petróleo e gás & 0,0511 & 0,3834 & 1 \\
\hline 4 & Minerais não-metálicos & 0,0451 & 0,7693 & 1 \\
\hline 5 & Siderurgia & 0,0386 & 0,7072 & 1 \\
\hline 6 & Metalurgia de não-ferrosos & 0,0400 & 0,5979 & 1 \\
\hline 7 & Outros Produtos Metalúrgicos & 0,0554 & 0,9187 & 1 \\
\hline 8 & Máquinas e Equipamentos & 0,0426 & 0,7302 & 1 \\
\hline 9 & Material Elétrico & 0,0837 & 1,0653 & 1 \\
\hline 10 & Equipamentos Eletrônicos & 0,0669 & 0,9284 & 1 \\
\hline 11 & Automóveis, caminhões e ônibus & 0,0429 & 0,9016 & 1 \\
\hline 12 & Peças e outros veículos & 0,0618 & 0,9911 & 1 \\
\hline 13 & Madeira e Mobiliário & 0,0445 & 0,8412 & 1 \\
\hline 14 & Celulose, Papel e Gráfica & 0,0474 & 0,7705 & 1 \\
\hline 15 & Indústria da Borracha & 0,0375 & 0,6427 & 1 \\
\hline 16 & Elementos Químicos & 0,0311 & 0,6599 & 1 \\
\hline 17 & Refino de Petróleo & 0,0357 & 0,6262 & 1 \\
\hline 18 & Químicos Diversos & 0,0469 & 0,5402 & 1 \\
\hline 19 & Farmacêuticos e Veterinários & 0,0339 & 0,6385 & 1 \\
\hline 20 & Artigos Plásticos & 0,0519 & 0,7552 & 1 \\
\hline 21 & Indústria Têxtil & 0,0702 & 0,8899 & 1 \\
\hline 22 & Artigos do Vestuário & 0,0666 & 0,9047 & 1 \\
\hline 23 & Calçados & 0,0483 & 0,7873 & 1 \\
\hline 24 & Indústria do Café & 0,0186 & 0,5499 & 1 \\
\hline 25 & Beneficiamento de Produtos Vegetais & 0,0407 & 0,6898 & 1 \\
\hline 26 & Abate de Animais & 0,0317 & 0,6536 & 1 \\
\hline 27 & Indústria de Laticínios & 0,0334 & 0,6783 & 1 \\
\hline 28 & Fabricação de Açúcar & 0,0449 & 0,7052 & 1 \\
\hline 29 & Fabricação de Óleos Vegetais & 0,0246 & 0,4418 & 1 \\
\hline 30 & Outros Produtos Alimentares & 0,0370 & 0,6940 & 1 \\
\hline 31 & Indústrias Diversas & 0,0621 & 0,9429 & 1 \\
\hline 32 & $\begin{array}{l}\text { Serviços Industriais de Utilidade } \\
\text { Pública }\end{array}$ & 0,0448 & 0,7457 & 1 \\
\hline 33 & Construção Civil & 0,0298 & 0,7197 & 1 \\
\hline 34 & Comércio & 0,0555 & 0,7747 & 1 \\
\hline 35 & Supermercados & 0,0555 & 0,7747 & 1 \\
\hline 36 & Transportes & 0,0501 & 0,7526 & 1 \\
\hline 37 & Comunicações & 0,0680 & 0,8057 & 1 \\
\hline 38 & Instituições Financeiras & 0,0747 & 0,8916 & 1 \\
\hline 39 & Serviços Prestados às Famílias & 0,0391 & 0,7923 & 1 \\
\hline 40 & Serviços Prestados às Empresas & 0,0459 & 0,7006 & 1 \\
\hline 41 & Aluguel de Imóveis & 0,0179 & 0,5356 & 1 \\
\hline & Administração Pública & 0,0427 & 0,7294 & 1 \\
\hline 43 & Serviços Privados não-mercantis & 0,0353 & 0,6726 & 1 \\
\hline
\end{tabular}

Fonte: IBGE (2002) 


\section{RESULTADOS E DISCUSSÃO}

Os resultados da pesquisa constituem-se dos valores dos indicadores econômicos detalhados no capítulo teórico, os quais foram obtidos utilizando-se as matrizes de insumo-produto do Brasil para os anos de 1990, 1995 e 1999, que incluem o setor supermercadista desagregado (setor 35-Supermercados). Os valores obtidos foram resumidos em Tabelas e gráficos posteriormente analisados baseando-se na revisão de literatura apresentada.

A desagregação do setor supermercadista na matriz insumo-produto do Brasil foi realizada por meio de duas metodologias descritas no capítulo teórico. A primeira baseia-se na própria metodologia das contas nacionais, denominada neste trabalho como "metodologia tradicional". As Contas Nacionais, utilizadas para a construção da matriz, consideram somente os custos operacionais básicos do comércio e que este produz, predominantemente, margem de comercialização. A segunda metodologia parte dos resultados obtidos da desagregação do setor supermercadista do setor 34-Comércio para incorporar em seus custos operacionais os valores básicos das mercadorias comercializadas pelos supermercados, tratando a atividade como uma indústria, a qual vende seu produto (neste caso, serviço) ao consumidor final.

Os resultados obtidos pela utilização das matrizes de insumo-produto com o setor 35-Supermercados desagregado pela metodologia tradicional estão indicados pelos anos 1990, 1995 e 1999. Os valores calculados utilizando as matrizes com o setor supermercadista desagregado pela nova proposta metodológica estão identificados pelos anos 1995n e 1999n. 


\subsection{Produto Interno Bruto do setor supermercadista}

O Produto Interno Bruto setorial (PIB setorial), de acordo com a metodologia apresentada no referencial teórico, engloba não somente o valor agregado do próprio setor, mas também o valor agregado de produtos e serviços destinados aos supermercados por setores fornecedores de bens e serviços. Os valores do PIB setorial dos supermercados para os anos de 1990, 1995 e 1999, calculados pela metodologia tradicional, constam da Tabela 23. As matrizes de insumo-produto que possuem o setor supermercadista desagregado pela nova proposta metodológica foram utilizadas para calcular o PIB setorial dos anos de 1995 e 1999 e os resultados estão resumidos na Tabela 24.

Tabela 23. Produto Interno Bruto do setor supermercadista, pessoal ocupado e produtividade do trabalho.

\begin{tabular}{|c|c|c|c|c|c|c|c|c|c|}
\hline \multirow[b]{2}{*}{ Segmentos } & \multicolumn{3}{|c|}{1990} & \multicolumn{3}{|c|}{1995} & \multicolumn{3}{|c|}{1999} \\
\hline & VA* & $\begin{array}{c}\text { Pessoal } \\
\text { ocupado }\end{array}$ & $\begin{array}{l}\text { Produtividade } \\
\text { do trabalho } * *\end{array}$ & VA & $\begin{array}{l}\text { Pessoal } \\
\text { ocupado }\end{array}$ & $\begin{array}{c}\text { Produtividade } \\
\text { do trabalho }\end{array}$ & VA & $\begin{array}{c}\text { Pessoal } \\
\text { ocupado }\end{array}$ & $\begin{array}{c}\text { Produtividade } \\
\text { do trabalho }\end{array}$ \\
\hline Fornecedores & 169,55 & 10.968 & 15,46 & 425,86 & 15.178 & 28,06 & 325,726 & 10.886 & 29,92 \\
\hline Supermercados & $2 . .540,40$ & 460.000 & 5,52 & $4.676,13$ & 655.200 & 7,14 & $3.301,88$ & 670.000 & 4,93 \\
\hline Serviços & $3.142,04$ & 213.248 & 14,73 & $4.558,30$ & 314.551 & 14,49 & $3.639,01$ & 246.990 & 14,73 \\
\hline Total & $5.851,98$ & 684.216 & 8,55 & $9.660,30$ & 984.929 & 9,81 & $7.266,62$ & 927.876 & 7,83 \\
\hline
\end{tabular}

* valor agregado em milhões de reais de 1999

** valor em milhares de reais de 1999/trabalhador

Tabela 24. Produto Interno Bruto do setor, pessoal ocupado e produtividade do trabalho obtidos com as matrizes da nova proposta metodológica.

\begin{tabular}{lrrrrrr}
\hline \multirow{3}{*}{ Segmentos } & \multicolumn{3}{c}{$1995 \mathrm{n}$} & & $1999 \mathrm{n}$ & \\
\cline { 2 - 7 } & \multicolumn{1}{c}{$\begin{array}{c}\text { Valor } \\
\text { agregado* }\end{array}$} & $\begin{array}{c}\text { Pessoal } \\
\text { ocupado }\end{array}$ & $\begin{array}{c}\text { Produtividade } \\
\text { do trabalho** }\end{array}$ & $\begin{array}{c}\text { Valor } \\
\text { agregado }\end{array}$ & $\begin{array}{c}\text { Pessoal } \\
\text { ocupado }\end{array}$ & $\begin{array}{c}\text { Produtividade } \\
\text { do trabalho }\end{array}$ \\
\hline Fornecedores & $11.552,35$ & 1.066 .733 & 10,83 & $13.347,62$ & 1.118 .510 & 11,93 \\
Supermercados & $4.676,12$ & 655.200 & 7,14 & $3.301,88$ & 670.000 & 4,93 \\
Serviços & $28.860,79$ & 1.991 .571 & 14,49 & $30.125,18$ & 2.044 .682 & 14,73 \\
Total & $45.089,26$ & 3.713 .504 & 12,14 & $46.774,68$ & 3.833 .192 & 12,20 \\
\hline
\end{tabular}

* valor em milhares de reais de 1999

** valor em milhares de reais de 1999/trabalhador 
A metodologia apresentada no referencial teórico torna possível analisar a participação do conjunto de fornecedores do setor supermercadista no PIB setorial. Os fornecedores dos produtos vendidos aos supermercados eram responsáveis por aproximadamente 3\% do valor agregado em 1990, e por 4,5\% em 1995 e em 1999, de acordo com os resultados da Tabela 23. Valores diferentes são encontrados quando o PIB é calculado utilizando as matrizes de insumo-produto que possuem o setor desagregado de acordo com a nova proposta metodológica. Nesse caso, os fornecedores dos supermercados respondem por cerca de 26\% do PIB setorial em 1995 e por $29 \%$ em 1999.

Os resultados da nova metodologia ilustram o conceito de que o conjunto de firmas que constituem o grupo de fornecedores passa a englobar empresas que têm seus produtos revendidos pelos supermercados, principalmente indústrias alimentícias, e também do setor 1-Agropecuária, que vende sua produção como matéria-prima à indústria de alimentos e diretamente ao varejo (produtos in natura ou com mínimo beneficiamento).

O próprio setor supermercadista contribui para o valor agregado de seus produtos e serviços. As participações do setor no Produto Interno Bruto da cadeia de comercialização são de aproximadamente 43\% em 1990, $48 \%$ em 1995 e $45 \%$ em 1999, considerando-se os valores calculados pela metodologia tradicional. Nota-se que houve queda significativa do valor absoluto entre 1995 e 1999, principalmente devido à diminuição do salário médio pago pelo setor supermercadista e do lucro líquido (Excedente Operacional Bruto).

As participações do setor supermercadista no PIB setorial utilizando a nova proposta metodológica são relativamente menores em relação aos resultados da metodologia tradicional, cerca de 10\% em 1995n e 7\% em 1999n. Observa-se que os resultados obtidos para as duas metodologias indicam a diminuição da contribuição do próprio setor para PIB setorial, tanto em valores absolutos como em participação (\%).

O setor serviços emprega mão-de-obra de menor qualificação que outros setores da economia, sendo que o trabalhador com esse perfil sofreu mais fortemente as conseqüências de altas taxas de desemprego do período (1995/99). Assim, houve diminuição da média dos salários pagos aos funcionários dos supermercados, que se tornou menor que o salário médio do comércio. Além disso, o Excedente Operacional Bruto, que 
se aproxima das denominações contábeis de Lucro Líquido e Remuneração aos proprietários (donos do capital), apresentou significativa queda neste período, principalmente devido à maior concorrência no setor. O Excedente Operacional Bruto (EOB) do setor supermercadista passou de aproximadamente R \$ 2,5 bilhões em 1995 para R\$ 1,25 bilhões em 1999 (valores de 1999), de acordo com dados da Pesquisa Anual de Comércio (IBGE) e da Associação Brasileira de Supermercados .

A consolidação de empresas também pode ser apontada como um fator que contribuiu para a diminuição do PIB setorial, pois as economias de escala incluem menor necessidade de mão-de-obra e diminuição do valor total das remunerações, que é um componente do Excedente Operacional Bruto.

A metodologia de cálculo do PIB setorial torna possível determinar o número de postos de trabalho existentes dentro do sistema de produção e distribuição dos supermercados, bem como os empregos que dependem direta e indiretamente da atividade do setor supermercadista. A produtividade do trabalho dentro dos três elos do sistema também foi calculada, medida em valor agregado por trabalhador.

Baseando-se nas matrizes de insumo-produto elaboradas pela metodologia tradicional, constatou-se que o sistema de produção e distribuição dentro do qual os supermercados fazem parte empregava aproximadamente 680 mil pessoas em 1990, 980 mil em 1995 e 930 mil em 1999. As matrizes de insumo-produto que possuem o setor 35Supermercados construído pela nova proposta metodológica indicaram a existência de 3,7 milhões de postos de trabalho em 1995 e de 3,8 milhões de empregos em 1999. Os setores aos quais pertencem estes postos de trabalho e a influência da produção do setor supermercadista sobre o emprego serão detalhados e discutidos posteriormente.

A análise detalhada dos valores obtidos pela nova metodologia, resumidos na Tabela 24, indica que a maior parte dos empregos da cadeia de distribuição dos supermercados se concentra nos setores prestadores de serviços (cerca de 54\% em 1995 e DE 53\% em 1999). Em segundo lugar em número de postos de trabalho está o próprio setor supermercadista, com aproximadamente 655 mil pessoas em 1995, que representam $18 \%$ do total de postos de trabalho e 670 mil em 1999, representando17\% do total de 
empregos. Os setores fornecedores de bens utilizados tanto para consumo nas empresas supermercadistas como para revenda possuíam cerca de 1.060 mil pessoas ocupadas em 1995, representando $28 \%$ do total e 1.120 mil em 1999, 30\% do total.

A produtividade do trabalho é consideravelmente menor no setor supermercadista que nos outros elos do sistema. Além disso, a produtividade dos trabalhadores do setor supermercadista diminuiu e das empresas que prestam serviços ao sistema variou pouco no período 1990/99. No caso dos setores fornecedores de serviços, os valores indicam que estas são atividades que empregam um número cada vez maior de pessoas, recebendo trabalhadores da indústria e agropecuária. O resultado final, porém, é a diminuição da produtividade do trabalho nestas atividades, levando a um menor nível de salário.

A diminuição da produtividade do trabalho no setor supermercadista, calculada como Valor Adicionado por trabalhador, diverge dos valores da Tabela 11, que considera a produtividade da mão-de-obra medida como pessoas ocupadas por loja, caixa e área de vendas (m2). A análise dos diferentes indicadores permite observar que houve um aumento da produtividade do trabalho nas lojas pertencentes ao setor, mas que este ganho de eficiência não resultou em aumento de salário. O número de trabalhadores por loja, área de vendas e caixas diminuiu como conseqüência da automação comercial de frente e de retaguarda, além do fluxo eletrônico de informações entre lojas, matriz e fornecedores. Deve-se considerar também o aumento do tamanho médio das lojas, resultando em menor número de pessoas por espaço. Este fator decorre, principalmente, da abertura de supermercados mais amplos, superlojas, hipermercados e da transformação de lojas de um ou dois caixas (pequenas empresas) em supermercados compactos.

Os resultados da pesquisa levam à conclusão de que o valor do PIB setorial dos supermercados é derivado principalmente dos serviços prestados ao sistema e, em menor escala, dos fornecedores de produtos aos supermercados, os quais são constituídos por ampla gama de indústrias de produtos alimentícios e não-alimentícios e a própria agropecuária. Portanto, pode-se afirmar que os produtos comercializados pelos supermercados possuem alto valor agregado em serviços e processamento, característica 
que foi reforçada no período 1995/99, pois a contribuição dos fornecedores e prestadores de serviços para o PIB setorial dos supermercados aumentou em valor absoluto e relativo.

A nova metodologia proposta para analisar o setor supermercadista permite obter resultados mais realistas da contribuição da atividade no sistema econômico, pois leva em consideração as aquisições de produtos e serviços pelos supermercados e não apenas seus custos operacionais básicos. A Associação Brasileira de Supermercados (ABRAS) estima em aproximadamente $6,1 \%$ (média do período) a participação dos supermercados no Produto Interno Bruto do Brasil no período 1995/99, valor obtido pela razão entre faturamento bruto do setor e o Produto Interno Bruto do país. Os resultados da pesquisa apresentam valores da ordem de 5,0\% do PIB para 1995 e de 4,8\% em 1999. Esses são números mais próximos dos valores apresentados pela ABRAS que os resultados do PIB setorial obtidos a partir das matrizes de insumo-produto da metodologia tradicional, que apontam a participação do PIB setorial do setor supermercadista em 1,2\% do Produto Interno Bruto nacional em 1995 e em 0,9\% em 1999.

O Produto Interno Bruto do setor supermercadista (Tabela 24) cresceu de $\mathrm{R} \$ 45,1$ bilhões em 1995 para R \$ 46,8 bilhões em 1999, em valores do ano de 1999, representando um crescimento de 3,8\% do PIB setorial entre 1995/99, enquanto o valor agregado do setor 34-Comércio (incluindo supermercados) apresentou um decréscimo de aproximadamente 0,2\% no período. É importante citar que a variação do valor agregado do comércio no ano de 1998 foi fortemente negativa, -5,14\% em relação ao ano anterior, o que influenciou o desempenho dos supermercados na segunda metade da década de 1990. Assim, o setor supermercadista teve um melhor desempenho do que o Comércio em geral no período $1995 / 99$.

A Tabela 25 apresenta a contribuição de cada setor da economia que participa do PIB setorial do setor 35-Supermercados, número de pessoas ocupadas e produtividade do trabalho. Os resultados pertencem ao ano de 1999 com o setor supermercadista desagregado pela nova proposta metodológica. Observa-se que o próprio setor 35Supermercados contribuiu com pequena parcela do montante de $\mathrm{R} \$ 46,1$ bilhões do Produto Interno Bruto setorial. Existem setores como 36-Transportes e 40-Serviços 
prestados às empresas que têm participações maiores. Além disso, para cada posto de trabalho no setor supermercadista, há pelo menos mais quatro trabalhadores em outros setores da economia para atender à demanda final dos supermercados.

Os resultados resumidos na Tabela 25 mostram que a maior contribuição para o PIB setorial dos supermercados foi do setor 36-Transportes, com aproximadamente R\$ 8 bilhões. Este setor emprega 860 mil pessoas para atender o sistema de produção e comercialização que possui o setor supermercadista como equipamento de distribuição para o consumidor final. Na classificação dos setores mais importantes para a cadeia, encontram-se: 36-Transportes, 40-Serviços prestados às empresas, 1-Agropecuária, 34Comércio, 40-Administração pública, 30-Outros produtos alimentares e 25Beneficiamento de produtos vegetais. Para atender ao sistema, o setor 36-Transportes emprega um número de pessoas maior que o próprio setor 35-Supermercados e a atividade 1-Agropecuária emprega cerca de 600 mil pessoas, valor próximo dos 670 mil postos de trabalho do setor supermercadista no ano de 1999.

A produtividade do trabalho, medida em valor adicionado por pessoa, apresenta uma variação muito grande entre os setores da economia. No setor 1-Agropecuária, cada trabalhador gerou, ao longo do ano de 1999, cerca de $\mathrm{R} \$ 4,9$ mil em remunerações aos empregados, lucro e pagamentos aos donos do capital, enquanto no setor 17-Refino de petróleo a produtividade do trabalho foi de aproximadamente $\mathrm{R} \$ 577$ mil por trabalhador.

Os resultados desagregados do Produto Interno Bruto do setor supermercadista permitem notar a importância deste para diferentes atividades econômicas, incluindo transportes, comércio, agropecuária e indústria de alimentos. Um sistema complexo que emprega cerca de 3,8 milhões de pessoas e gera aproximadamente 5\% da renda do país. 
Tabela 25. Participação dos setores no Produto Interno Bruto (PIB setorial), pessoal ocupado e produtividade do trabalho no sistema do setor 35-Supermercados.

\begin{tabular}{|c|c|c|c|c|c|c|}
\hline & & \multicolumn{2}{|c|}{ Valor agregado } & \multicolumn{2}{|c|}{ Pessoal ocupado } & \multirow{2}{*}{$\begin{array}{l}\text { Produtividade } \\
\text { do trabalho } \\
\text { (R\$mil/pessoa) }\end{array}$} \\
\hline & & Valor (R\$ mil) & $\%$ & Valor & $\%$ & \\
\hline 1 & Agropecuária & 2.954 .868 & 6,3 & 602.725 & 15,7 & 4,9 \\
\hline 2 & Extrativa Mineral & 4.259 & 0,0 & 204 & 0,0 & 20,9 \\
\hline 3 & Petróleo e gás & 109 & 0,0 & 0 & 0,0 & 252,0 \\
\hline 4 & Minerais não-metálicos & 86.130 & 0,2 & 4.296 & 0,1 & 20,0 \\
\hline 5 & Siderurgia & 1.597 & 0,0 & 14 & 0,0 & 111,4 \\
\hline 6 & Metalurgia de não-ferrosos & 20.738 & 0,0 & 322 & 0,0 & 64,3 \\
\hline 7 & Outros Produtos Metalúrgicos & 124.053 & 0,3 & 9.295 & 0,2 & 13,3 \\
\hline 8 & Máquinas e Equipamentos & 68.322 & 0,1 & 1.524 & 0,0 & 44,8 \\
\hline 9 & Material Elétrico & 209.339 & 0,4 & 6.667 & 0,2 & 31,4 \\
\hline 10 & Equipamentos Eletrônicos & 354.538 & 0,8 & 6.434 & 0,2 & 55,1 \\
\hline 11 & Automóveis, caminhões e ônibus & 1.090 & 0,0 & 14 & 0,0 & 76,6 \\
\hline 12 & Peças e outros veículos & 3.920 & 0,0 & 130 & 0,0 & 30,2 \\
\hline 13 & Madeira e Mobiliário & 21.772 & 0,0 & 2.596 & 0,1 & 8,4 \\
\hline 14 & Celulose, Papel e Gráfica & 663.616 & 1,4 & 30.997 & 0,8 & 21,4 \\
\hline 15 & Indústria da Borracha & 205 & 0,0 & 4 & 0,0 & 53,2 \\
\hline 16 & Elementos Químicos & 9.020 & 0,0 & 68 & 0,0 & 132,9 \\
\hline 17 & Refino de Petróleo & 15.489 & 0,0 & 27 & 0,0 & 577,1 \\
\hline 18 & Químicos Diversos & 60.492 & 0,1 & 1.168 & 0,0 & 51,8 \\
\hline 19 & Farmacêuticos e Veterinários & 1.601 .257 & 3,4 & 23.932 & 0,6 & 66,9 \\
\hline 20 & Artigos Plásticos & 81.123 & 0,2 & 4.763 & 0,1 & 17,0 \\
\hline 21 & Indústria Têxtil & 51.989 & 0,1 & 2.724 & 0,1 & 19,1 \\
\hline 22 & Artigos do Vestuário & 246.694 & 0,5 & 91.532 & 2,4 & 2,7 \\
\hline 23 & Calçados & 77.513 & 0,2 & 10.348 & 0,3 & 7,5 \\
\hline 24 & Indústria do Café & 268.324 & 0,6 & 6.698 & 0,2 & 40,1 \\
\hline 25 & Beneficiamento de Produtos Vegetais & 1.569 .174 & 3,4 & 69.099 & 1,8 & 22,7 \\
\hline 26 & Abate de Animais & 678.953 & 1,5 & 34.559 & 0,9 & 19,6 \\
\hline 27 & Indústria de Laticínios & 856.989 & 1,8 & 23.236 & 0,6 & 36,9 \\
\hline 28 & Fabricação de Açúcar & 146.969 & 0,3 & 6.435 & 0,2 & 22,8 \\
\hline 29 & Fabricação de Óleos Vegetais & 354.715 & 0,8 & 3.282 & 0,1 & 108,1 \\
\hline 30 & Outros Produtos Alimentares & 2.396 .853 & 5,1 & 153.707 & 4,0 & 15,6 \\
\hline 31 & Indústrias Diversas & 231.829 & 0,5 & 17.526 & 0,5 & 13,2 \\
\hline 32 & Serviços Industriais de Utilidade Pública & 116.982 & 0,3 & 873 & 0,0 & 134,1 \\
\hline 33 & Construção Civil & 68.698 & 0,1 & 3.311 & 0,1 & 20,7 \\
\hline 34 & Comércio & 2.425 .561 & 5,2 & 388.712 & 10,1 & 6,2 \\
\hline 35 & Supermercados & 3.301 .881 & 7,1 & 670.000 & 17,5 & 4,9 \\
\hline 36 & Transportes & 8.026 .971 & 17,2 & 861.457 & 22,5 & 9,3 \\
\hline 37 & Comunicações & 2.694.075 & 5,8 & 21.553 & 0,6 & 125,0 \\
\hline 38 & Instituições Financeiras & 2.814.979 & 6,0 & 39.043 & 1,0 & 72,1 \\
\hline 39 & Serviços Prestados às Famílias & 509.766 & 1,1 & 98.032 & 2,6 & 5,2 \\
\hline 40 & Serviços Prestados às Empresas & 5.917 .651 & 12,7 & 455.204 & 11,9 & 13,0 \\
\hline 41 & Aluguel de Imóveis & 3.483 .936 & 7,4 & 7.972 & 0,2 & 437,0 \\
\hline 42 & Administração Pública & 4.252.239 & 9,1 & 172.715 & 4,5 & 24,6 \\
\hline & Serviços Privados não-mercantis & 0 & 0,0 & 0 & 0,0 & 0,0 \\
\hline Tot & & 46.774 .680 & 100 & 3.833 .197 & 100 & 12,2 \\
\hline
\end{tabular}




\subsection{Geração de emprego}

A teoria insumo-produto permite mensurar o efeito de um aumento da demanda final de determinada indústria sobre o número de pessoas ocupadas na própria atividade e sobre outras indústrias. Para realizar esta análise, foram calculados os multiplicadores de emprego tipos I e II segundo a metodologia anteriormente descrita e os valores totais de empregos diretos, indiretos e induzidos gerados. A análise conjunta dos resultados é importante, pois os valores dos multiplicadores de empregos não estão relacionados diretamente com os valores totais de empregos gerados.

O resumo dos resultados para a capacidade de geração de emprego dos setores agrupados se encontra na Tabela 26. Os valores dos multiplicadores de empregos dos setores de serviços apresentaram o maior crescimento, bem como os 35-Supermercados. Os valores absolutos de empregos gerados dos setores (médias) tiveram uma tendência de queda, quando se analisam os resultados da metodologia tradicional. Os valores apresentados para a nova proposta metodológica indicam um aumento do número de empregos gerados. Porém, este maior valor absoluto ocorre por característica da nova metodologia de introduzir um efeito induzido na economia pela incorporação dos valores a preços básicos das mercadorias comercializadas pelos 35-Supermercados como seus custos operacionais. Esta característica intrínseca da nova metodologia será analisada em detalhes posteriormente. 
Tabela 26. Multiplicadores de emprego tipos I e II e empregos totais (médias) dos setores agrupados.

\begin{tabular}{|c|c|c|c|c|c|c|c|c|c|c|c|}
\hline \multirow{2}{*}{ Setor } & & \multicolumn{2}{|c|}{1990} & \multicolumn{2}{|c|}{1995} & \multicolumn{2}{|c|}{1999} & \multicolumn{2}{|c|}{$1995 n$} & \multicolumn{2}{|c|}{$1999 n$} \\
\hline & & $\mathrm{I}$ & II & I & II & $\mathrm{I}$ & II & $\mathrm{I}$ & II & $\mathrm{I}$ & II \\
\hline \multicolumn{12}{|c|}{ Multiplicador de emprego } \\
\hline $1-4$ & Agropecuária e extrativismo & 2,85 & 7,35 & 3,30 & 11,63 & 2,54 & 9,77 & 3,30 & 11,07 & 2,86 & 12,64 \\
\hline $5-31$ & Indústria & 8,44 & 15,99 & 7,97 & 17,65 & 7,31 & 18,00 & 7,97 & 16,87 & 8,32 & 23,40 \\
\hline 35 & Supermercados & 1,18 & 2,08 & 1,19 & 2,32 & 1,18 & 2,00 & 6,49 & 11,17 & 6,70 & 13,24 \\
\hline $32-43$ & $\begin{array}{l}\text { Serviços } \\
\text { (menos supermercados) }\end{array}$ & 1,60 & 5,04 & 1,53 & 6,56 & 1,65 & 7,61 & 2,34 & 7,51 & 2,60 & 11,30 \\
\hline \multicolumn{12}{|c|}{ Empregos totais } \\
\hline $1-4$ & Agropecuária e extrativismo & & 151 & & 148 & & 121 & & 143 & & 147 \\
\hline $5-31$ & Indústria & & 142 & & 137 & & 111 & & 133 & & 141 \\
\hline 35 & Supermercados & & 226 & & 190 & & 185 & & 146 & & 154 \\
\hline $32-43$ & $\begin{array}{l}\text { Serviços } \\
\text { (menos supermercados) }\end{array}$ & & 181 & & 180 & & 169 & & 173 & & 200 \\
\hline
\end{tabular}

Os valores de multiplicador de emprego tipos I e II constam das Tabelas 27 e 28. A Tabela 27 apresenta os resultados do setor 35-Supermercados desagregado pela metodologia tradicional (1990/95/99) e a Tabela 28 possui os valores obtidos a partir da nova proposta metodológica (1995n e 1999n). O multiplicador tipo I se refere ao efeito sobre os empregos gerados direta e indiretamente e o multiplicador tipo II engloba efeitos diretos, indiretos e induzidos (efeito total) sobre a capacidade de geração de emprego. Os empregos induzidos são aqueles que surgem pelo efeito do aumento do consumo derivado da renda adicional auferida pelos consumidores, a qual é proveniente do aumento de produção desencadeado pela variação da demanda final de determinado setor.

Analisando a Tabela 27 nota-se que para a maior parte dos setores, os valores do multiplicador de emprego tipo I (empregos diretos e indiretos) diminuiu na década de 1990. Porém, os setores tiveram em sua maioria um aumento do multiplicador de emprego tipo II, que inclui o efeito induzido. Este efeito pode ser calculado pela diferença entre os multiplicadores tipo I e II. Observa-se que três grupos de setores tiveram seus multiplicadores de emprego tipo II aumentados. Porém, o efeito induzido 
aumentou fortemente na indústria, passando de 7,55, valor obtido da diferença entre os multiplicadores tipos I $(8,44)$ e II $(15,99)$ em 1990 para 10,69, diferença entre 18,00 (tipo II) e 7,31 (multiplicador tipo I) em 1999 para os resultados das matrizes de insumoproduto da metodologia tradicional.

Os valores da nova proposta metodológica são relativamente maiores que aqueles encontrados pela metodologia tradicional, pois o efeito induzido do multiplicador passa de 8,9, diferença entre 16,87 (multiplicador tipo II) e 7,97 (tipo I) em 1995 para 15,08 em 1999n, diferença obtida entre 23,40 e 8,32. Estes resultados indicam maior capacidade de geração de empregos pelo aumento de produção da indústria sobre os outros setores da economia. Observando as Tabelas 27 e 28, determina-se que os maiores valores dos multiplicadores de emprego nas duas séries de resultados pertencem aos setores 17-Refino de petróleo, 29-Fabricação de óleos vegetais e 5-Siderurgia.

Para o setor 35-Supermercados, observa-se que os valores calculados utilizando a desagregação pela metodologia tradicional são menores que as médias da economia. Os multiplicadores de emprego calculados para o setor 35-Supermercados utilizando as matrizes de insumo-produto contendo o setor desagregado pela nova metodologia permanecem próximos das médias no período 1995/99. Portanto, o setor supermercadista possui importância relativamente média em termos de capacidade de geração de empregos.

O setor supermercadista, analisado pela nova metodologia, tem seus multiplicadores de emprego em 1999n superiores aos apresentados em 1995n, indicando principalmente um forte efeito induzido, que pode ser mensurado pela diferença entre os multiplicadores do tipo I e II. A diferença entre os multiplicadores aumenta de 4,68 em 1995 para 6,54 em 1999, revelando um maior efeito da renda gerada pelo aumento de produção do setor supermercadista sobre a economia. 
Tabela 27. Multiplicadores de emprego tipos I e II, valores obtidos de acordo com a metodologia tradicional.

\begin{tabular}{|c|c|c|c|c|c|c|c|}
\hline \multirow{2}{*}{\multicolumn{2}{|c|}{ Setor }} & \multicolumn{2}{|c|}{1990} & \multicolumn{2}{|c|}{1995} & \multicolumn{2}{|c|}{1999} \\
\hline & & \multirow{2}{*}{$\begin{array}{l}\mathrm{I} \\
1,27\end{array}$} & \multirow{2}{*}{$\begin{array}{ll}\text { II } \\
1,61\end{array}$} & \multirow{2}{*}{$\begin{array}{ll}\mathrm{I} \\
1,26\end{array}$} & \multirow{2}{*}{$\begin{array}{ll}\text { II } \\
1,72\end{array}$} & \multirow{2}{*}{$\begin{array}{ll}\mathrm{I} \\
1,29\end{array}$} & \multirow{2}{*}{$\begin{array}{l}\text { II } \\
1,83\end{array}$} \\
\hline 1 & Agropecuária & & & & & & \\
\hline 2 & Extrativa Mineral & 1,88 & 4,21 & 2,12 & 5,63 & 1,88 & 4,79 \\
\hline 3 & Petróleo e gás & 6,05 & 18,91 & 7,76 & 34,01 & 5,03 & 27,51 \\
\hline 4 & Minerais não-metálicos & 2,18 & 4,66 & 2,05 & 5,17 & 1,98 & 4,95 \\
\hline 5 & Siderurgia & 10,61 & 23,91 & 11,54 & 32,12 & 12,94 & 37,14 \\
\hline 6 & Metalurgia de não-ferrosos & 6,81 & 17,69 & 6,52 & 22,31 & 6,93 & 20,95 \\
\hline 7 & Outros Produtos Metalúrgicos & 1,95 & 4,27 & 1,83 & 4,49 & 1,82 & 4,37 \\
\hline 8 & Máquinas e Equipamentos & 2,75 & 7,23 & 2,24 & 7,49 & 2,07 & 6,96 \\
\hline 9 & Material Elétrico & 2,37 & 5,31 & 2,94 & 8,31 & 3,84 & 10,74 \\
\hline 10 & Equipamentos Eletrônicos & 2,79 & 6,75 & 3,11 & 9,97 & 3,09 & 9,84 \\
\hline 11 & Automóveis, caminhões e ônibus & 7,35 & 18,57 & 6,83 & 21,36 & 7,16 & 21,21 \\
\hline 12 & Peças e outros veículos & 2,97 & 7,51 & 3,03 & 8,85 & 3,30 & 9,40 \\
\hline 13 & Madeira e Mobiliário & 2,05 & 3,43 & 1,95 & 3,30 & 1,85 & 3,21 \\
\hline 14 & Celulose, Papel e Gráfica & 3,16 & 7,19 & 2,98 & 7,47 & 2,96 & 7,43 \\
\hline 15 & Indústria da Borracha & 4,55 & 10,94 & 5,04 & 14,14 & 5,35 & 14,43 \\
\hline 16 & Elementos Químicos & 15,60 & 28,57 & 12,59 & 26,96 & 11,83 & 28,73 \\
\hline 17 & Refino de Petróleo & 16,36 & 53,10 & 12,25 & 62,52 & 19,58 & 101,12 \\
\hline 18 & Químicos Diversos & 3,71 & 9,79 & 5,07 & 15,87 & 4,19 & 13,05 \\
\hline 19 & Farmacêuticos e Veterinários & 5,09 & 12,55 & 4,21 & 12,27 & 4,41 & 13,18 \\
\hline 20 & Artigos Plásticos & 1,92 & 4,89 & 1,86 & 5,99 & 1,71 & 4,68 \\
\hline 21 & Indústria Têxtil & 2,97 & 5,54 & 3,27 & 7,08 & 4,18 & 8,78 \\
\hline 22 & Artigos do Vestuário & 1,25 & 1,78 & 1,19 & 1,70 & 1,19 & 1,69 \\
\hline 23 & Calçados & 2,14 & 3,73 & 1,81 & 3,25 & 1,63 & 2,87 \\
\hline 24 & Indústria do Café & 24,98 & 37,03 & 15,30 & 24,31 & 14,39 & 23,47 \\
\hline 25 & Beneficiamento de Produtos Vegetais & 7,94 & 12,02 & 9,11 & 14,50 & 7,27 & 12,16 \\
\hline 26 & Abate de Animais & 17,16 & 24,27 & 13,11 & 20,19 & 12,25 & 19,26 \\
\hline 27 & Indústria de Laticínios & 22,68 & 33,24 & 19,83 & 31,05 & 12,69 & 21,53 \\
\hline 28 & Fabricação de Açúcar & 8,49 & 13,59 & 7,94 & 13,49 & 7,53 & 13,84 \\
\hline 29 & Fabricação de Óleos Vegetais & 43,93 & 67,62 & 53,62 & 85,80 & 37,60 & 65,13 \\
\hline 30 & Outros Produtos Alimentares & 4,49 & 7,85 & 4,44 & 8,11 & 3,75 & 7,01 \\
\hline 31 & Indústrias Diversas & 1,72 & 3,44 & 1,69 & 3,76 & 1,79 & 3,90 \\
\hline 32 & $\begin{array}{l}\text { Serviços Industriais de Utilidade } \\
\text { Pública }\end{array}$ & 2,71 & 10,31 & 2,34 & 14,30 & 2,97 & 19,15 \\
\hline 33 & Construção Civil & 2,09 & 4,61 & 1,67 & 4,08 & 1,57 & 3,71 \\
\hline 34 & Comércio & 1,18 & 2,14 & 1,17 & 2,26 & 1,20 & 2,26 \\
\hline 35 & Supermercados & 1,18 & 2,08 & 1,19 & 2,32 & 1,18 & 2,00 \\
\hline 36 & Transportes & 1,46 & 3,26 & 1,38 & 3,28 & 1,48 & 3,28 \\
\hline 37 & Comunicações & 1,32 & 3,77 & 1,55 & 7,29 & 2,28 & 13,89 \\
\hline 38 & Instituições Financeiras & 1,46 & 6,20 & 2,11 & 10,60 & 2,76 & 12,50 \\
\hline 39 & Serviços Prestados às Famílias & 1,38 & 2,51 & 1,27 & 2,21 & 1,23 & 2,05 \\
\hline 40 & Serviços Prestados às Empresas & 1,33 & 3,25 & 1,25 & 3,12 & 1,25 & 2,92 \\
\hline 41 & Aluguel de Imóveis & 3,02 & 19,05 & 1,96 & 26,15 & 1,76 & 28,68 \\
\hline 42 & Administração Pública & 1,51 & 4,97 & 1,79 & 6,02 & 1,61 & 5,19 \\
\hline & Serviços Privados não-mercantis & 1,02 & 1,35 & 1,01 & 1,29 & 1,01 & 1,24 \\
\hline Mé & & 6,02 & 12,20 & 5,75 & 14,10 & 5,30 & 14,47 \\
\hline
\end{tabular}


Tabela 28. Multiplicadores de emprego tipos I e II, valores obtidos de acordo com a nova proposta metodológica.

\begin{tabular}{|c|c|c|c|c|c|}
\hline \multirow{2}{*}{\multicolumn{2}{|c|}{ Setor }} & \multicolumn{2}{|c|}{$1995 n$} & \multicolumn{2}{|c|}{$1999 n$} \\
\hline & & \multirow{2}{*}{$\begin{array}{l}\mathrm{I} \\
1,26\end{array}$} & \multirow{2}{*}{$\begin{array}{l}\text { II } \\
1,66\end{array}$} & \multirow{2}{*}{$\begin{array}{l}\mathrm{I} \\
1,32\end{array}$} & \multirow{2}{*}{$\begin{array}{l}\text { II } \\
2,07\end{array}$} \\
\hline 1 & Agropecuária & & & & \\
\hline 2 & Extrativa Mineral & 2,12 & 5,50 & 2,08 & 6,10 \\
\hline 3 & Petróleo e gás & 7,76 & 32,15 & 5,84 & 36,03 \\
\hline 4 & Minerais não-metálicos & 2,05 & 4,96 & 2,21 & 6,34 \\
\hline 5 & Siderurgia & 11,54 & 30,51 & 15,09 & 49,05 \\
\hline 6 & Metalurgia de não-ferrosos & 6,52 & 21,03 & 8,53 & 28,62 \\
\hline 7 & Outros Produtos Metalúrgicos & 1,83 & 4,43 & 2,03 & 5,58 \\
\hline 8 & Máquinas e Equipamentos & 2,24 & 7,23 & 2,38 & 9,10 \\
\hline 9 & Material Elétrico & 2,94 & 8,06 & 4,70 & 14,66 \\
\hline & Equipamentos Eletrônicos & 3,11 & 9,43 & 3,77 & 13,33 \\
\hline 11 & Automóveis, caminhões e ônibus & 6,83 & 20,49 & 9,29 & 30,02 \\
\hline 12 & Peças e outros veículos & 3,03 & 8,65 & 4,01 & 12,76 \\
\hline 13 & Madeira e Mobiliário & 1,95 & 3,25 & 1,98 & 3,91 \\
\hline 14 & Celulose, Papel e Gráfica & 2,98 & 7,38 & 3,46 & 9,86 \\
\hline 15 & Indústria da Borracha & 5,04 & 13,40 & 6,47 & 19,57 \\
\hline 16 & Elementos Químicos & 12,59 & 25,58 & 12,84 & 35,99 \\
\hline 17 & Refino de Petróleo & 12,25 & 56,79 & 24,66 & 136,60 \\
\hline 18 & Químicos Diversos & 5,07 & 15,30 & 4,98 & 17,44 \\
\hline 19 & Farmacêuticos e Veterinários & 4,21 & 11,82 & 5,37 & 17,89 \\
\hline 20 & Artigos Plásticos & 1,86 & 5,70 & 1,94 & 6,07 \\
\hline 21 & Indústria Têxtil & 3,27 & 6,83 & 4,81 & 11,53 \\
\hline & Artigos do Vestuário & 1,19 & 1,71 & 1,24 & 1,94 \\
\hline & Calçados & 1,81 & 3,21 & 1,77 & 3,55 \\
\hline 24 & Indústria do Café & 15,30 & 23,38 & 15,15 & 27,84 \\
\hline & Beneficiamento de Produtos Vegetais & 9,11 & 14,07 & 7,90 & 15,00 \\
\hline & Abate de Animais & 13,11 & 19,58 & 13,08 & 23,15 \\
\hline 27 & Indústria de Laticínios & 19,83 & 29,98 & 13,56 & 26,08 \\
\hline & Fabricação de Açúcar & 7,94 & 13,18 & 8,24 & 17,26 \\
\hline & Fabricação de Óleos Vegetais & 53,62 & 82,94 & 41,21 & 81,20 \\
\hline & Outros Produtos Alimentares & 4,44 & 7,91 & 4,19 & 8,93 \\
\hline & Indústrias Diversas & 1,69 & 3,68 & 1,97 & 4,92 \\
\hline & Serviços Industriais de Utilidade Pública & 2,34 & 14,16 & 3,29 & 24,71 \\
\hline & Construção Civil & 1,67 & 3,87 & 1,70 & 4,62 \\
\hline & Comércio & 1,17 & 2,26 & 1,23 & 2,65 \\
\hline & Supermercados & 6,49 & 11,17 & 6,70 & 13,24 \\
\hline 36 & Transportes & 1,38 & 3,28 & 1,61 & 4,09 \\
\hline & Comunicações & 1,55 & 6,97 & 2,51 & 17,87 \\
\hline & Instituições Financeiras & 2,11 & 10,65 & 2,94 & 15,82 \\
\hline & Serviços Prestados às Famílias & 1,27 & 2,21 & 1,28 & 2,39 \\
\hline & Serviços Prestados às Empresas & 1,25 & 3,14 & 1,30 & 3,54 \\
\hline & Aluguel de Imóveis & 1,96 & 21,17 & 1,84 & 36,93 \\
\hline & Administração Pública & 1,79 & 6,24 & 1,71 & 6,48 \\
\hline & Serviços Privados não-mercantis & 1,01 & 1,31 & 1,01 & 1,31 \\
\hline & édia & 5,87 & 13,63 & 6,12 & 18,98 \\
\hline
\end{tabular}


Apesar da importância do multiplicador de emprego para analisar o impacto relativo sobre os setores, este indicador não leva em consideração o número de empregos totais (valor absoluto) necessários para suprir uma variação da demanda final de um determinado setor. Portanto, para melhor avaliar a capacidade de geração de empregos de cada indústria, deve-se determinar os valores absolutos de postos de trabalho que deverão ser criados devido ao aumento da demanda final pelos produtos e serviços da atividade. $\mathrm{O}$ número de empregos efetivamente gerados depende do número de pessoas ocupadas dentro do próprio setor e em outros direta e indiretamente relacionados a ele.

Para avaliar em detalhes a capacidade de geração de emprego dos setores, devese considerar os resultados apresentados nas Tabelas 29, 30 e 31, que trazem o número de empregos gerados para um aumento da demanda final do setor em um milhão de reais em valores de 1999. Observa-se que as indústrias que possuem os maiores valores de multiplicadores de empregos não são necessariamente as mesmas que geram o maior número de postos de trabalho para uma mesma variação da demanda final. Como exemplo, pode-se citar o setor 1-Agropecuária, que possui valores de multiplicadores de emprego relativamente baixos (2,07 para o multiplicador tipo II do ano de 1999, nova proposta metodológica), mas que gera um número total de empregos alto em comparação com os demais (237 empregos totais em 1999n para uma média de 159 para a economia).

Observa-se nas Tabelas 29 e 30 que as médias de empregos diretos, indiretos, induzidos e totais gerados diminuem no período 1990/99 para os resultados utilizando a desagregação do setor supermercadista pela metodologia tradicional., Isto indica novamente uma diminuição da capacidade de geração de empregos da economia como um todo para um aumento da demanda de mesmo valor. Os resultados da nova proposta metodológica, expostos na Tabela 31, para os empregos diretos e indiretos seguem a mesma tendência de diminuição. Porém, a geração de empregos induzidos possui tendência de crescimento, pois houve um aumento do volume de produtos comercializados quando se incorporam os valores a preços básicos como custos para o 
setor supermercadista, causando um efeito induzido adicional similar à endogeneização do consumo das famílias.

O setor 35-Supermercados é um importante gerador de empregos, segundo o critério de número de empregos totais, gerando 185 empregos em 1999 para um aumento da demanda final de um milhão de reais (Tabela 29). Os resultados da nova proposta metodológica, apresentados na Tabela 31, são de 154 postos de trabalho para o mesmo ano. A análise utilizando a nova proposta metodológica permite comparar a capacidade de geração de empregos do setor 35-Supermercados com outras indústrias, enquanto a comparação com o setor 34-Comércio é realizada por meio dos resultados com a metodologia tradicional (variação da demanda final por margem de comércio).

A Tabela 31 apresenta os resultados dos efeitos diretos, indiretos e induzidos do aumento da demanda final dos setores sobre o emprego, considerado o setor supermercadista pela nova proposta metodológica. No caso do setor 35-Supermercados, a maior parte dos empregos gerados pertence a outros setores. Os valores são, para o ano de 1995, 13 empregos diretos, 72 empregos indiretos (em setores relacionados diretamente) e 61 postos de trabalho em toda a economia, por efeito induzido pelos gastos de renda adicional por aumento da produção. Em 1999, esses valores se modificaram para 12 empregos diretos, 66 indiretos e 76 empregos por efeito induzido. A classificação por número total de empregos gerados coloca o setor 35-Supermercados em $17^{\mathrm{a}}$ posição em 1995 e $18^{\mathrm{a}}$ em 1999 , entre os 43 setores relacionados.

A análise detalhada dos resultados da Tabela 31 indica que o setor 35Supermercados diminuiu sua capacidade de geração de empregos diretos e indiretos, cujos valores passaram de 13 para 12 empregos diretos e de 72 para 66 empregos indiretos. Porém, o número de postos de trabalho gerados por efeito induzido aumentou no período 1995n/99n de 61 para 76 pessoas ocupadas.

O aumento do efeito induzido dos empregos gerados pelo aumento de produção do setor supermercadista no período 1995n/99n (Tabela 31) pode ser explicado pelo efeito do aumento de produção do setor supermercadista sobre o setor 34-Comércio, o qual aumentou consideravelmente sua capacidade de geração de empregos totais de 189 
em 1995n para 342 postos de trabalho em 1999n. O 34-Comércio é um dos principais setores que sofrem influência sobre o emprego com o aumento das vendas dos 35Supermercados, como será detalhado em análise posterior. Deve-se observar que a capacidade de geração de empregos do setor supermercadista está relacionada diretamente aos efeitos sobre seus fornecedores e outros setores que, apesar de não estabelecerem relações diretas com o setor 35-Supermercados, sofrem os efeitos da variação de sua demanda final.

A diminuição da capacidade de geração de empregos diretos e indiretos pelo setor 35-Supermercados está diretamente relacionada à utilização de novas tecnologias por parte do varejo e da indústria, amplamente discutidas na Revisão de literatura. No caso do setor supermercadista, a automação comercial se intensificou a partir do ano de 1995 e o efeito do uso de caixas automatizados, transferência eletrônica de informações entre a rede de lojas e a alta administração e junto aos fornecedores, além de outras inovações é apresentado no resultado da pesquisa como a diminuição do número de empregos diretos gerados (Tabelas 30 e 31). Para um aumento da demanda final de um milhão de reais, seriam gerados 13 postos de trabalho em 1995 e 12 em 1999, com base na nova proposta metodológica.

A diminuição do número de empregos indiretos gerados pelo aumento da demanda final do setor 35-Supermercados tem como principal causa a modernização da indústria de alimentos no período pelo uso de novas tecnologias que, ao mesmo tempo aumentam a produtividade do trabalho e diminuem a capacidade de geração de empregos. Os resultados da nova metodologia indicam que houve queda do número de empregos indiretos de 72 em 1995 para 66 em 1999 para uma variação da demanda final dos 35-Supermercados de um milhão de reais.

Os resultados da Tabela 31 incluem o maior efeito induzido determinado pela nova proposta metodológica, devido a endogeneização de parte do Consumo das famílias como custos operacionais do setor 35-Supermercados. O maior efeito induzido ocorre nos resultados de empregos induzidos no ano de 1999, pois no ano de 1995 o setor supermercadista tinha um faturamento bruto relativamente menor e comercializava 
volume pequeno de produtos não-alimentícios. É importante observar que ao mesmo tempo em que a nova metodologia introduz este desvio para os valores obtidos, também permite analisar melhor a importância do setor sobre o sistema econômico. O maior efeito induzido pode ser determinado pela diferença entre as médias dos empregos induzidos calculadas para os dois anos. Para a metodologia tradicional, os empregos induzidos passam de 75 em 1995 para 63 em 1999, enquanto para a nova metodologia, o valor é de 71 postos de trabalho em 1995 e 89 para 1999. Portanto, o valor adicional do efeito induzido da nova metodologia faz com que o total de empregos gerados aumente no período.

A Figura 8 permite avaliar os setores em relação ao tipo de emprego gerado pelo aumento de produção (diretos, indiretos e induzidos). Dos valores totais de empregos gerados pelos setores 1-Agropecuária, 22-Artigos do vestuário e 43- Serviços privados não-mercantis, a maior participação é de empregos diretos, e em menor escala os empregos induzidos e, em porcentagem muito pequena, empregos indiretos. Os setores de serviços têm como característica a geração de empregos por efeito induzido, enquanto a indústria caracteriza-se pela geração de empregos indiretos.

No caso específico do setor 35-Supermercados, analisado pela utilização da matriz de insumo-produto de 1999 elaborada pela nova proposta metodológica, observase que, do número total de empregos gerados pelo aumento de produção de um milhão de reais, a maior participação (cerca de 50\%) é de empregos induzidos, em menor porcentagem, os empregos indiretos (aproximadamente 46\%) e o número de empregos diretos é relativamente pequeno, cerca de $4 \%$. Os resultados indicam importantes efeitos indiretos e induzidos causados pelo aumento de vendas do setor supermercadista influenciando a geração de empregos nas indústrias relacionadas diretamente (empregos indiretos) e sobre toda a economia (empregos induzidos). Este último efeito promove a criação de empregos mesmo em atividades não ligadas diretamente ao setor supermercadista. 
Tabela 29. Geração de emprego total para a variação de um milhão de reais da demanda final e ordenação; resultados obtidos para a metodologia tradicional.

\begin{tabular}{|c|c|c|c|c|c|c|c|}
\hline \multirow{2}{*}{\multicolumn{2}{|c|}{ Setor }} & \multicolumn{2}{|c|}{1990} & \multicolumn{2}{|c|}{1995} & \multicolumn{2}{|c|}{1999} \\
\hline & & \multirow{2}{*}{$\frac{\text { ordem }}{3}$} & \multirow{2}{*}{$\begin{array}{r}\text { total } \\
256\end{array}$} & \multirow{2}{*}{$\frac{\text { ordem }}{3}$} & \multirow{2}{*}{$\frac{\text { total }}{255}$} & \multirow{2}{*}{$\begin{array}{c}\text { ordem } \\
3\end{array}$} & \multirow{2}{*}{$\frac{\text { total }}{209}$} \\
\hline$\overline{1}$ & Agropecuária & & & & & & \\
\hline 2 & Extrativa Mineral & 22 & 134 & 23 & 124 & 24 & 100 \\
\hline 3 & Petróleo e gás & 41 & 88 & 36 & 95 & 39 & 74 \\
\hline 4 & Minerais não-metálicos & 27 & 125 & 25 & 119 & 25 & 99 \\
\hline 5 & Siderurgia & 32 & 107 & 34 & 97 & 37 & 77 \\
\hline 6 & Metalurgia de não-ferrosos & 40 & 91 & 40 & 82 & 41 & 72 \\
\hline 7 & Outros Produtos Metalúrgicos & 18 & 147 & 20 & 132 & 21 & 106 \\
\hline 8 & Máquinas e Equipamentos & 29 & 120 & 30 & 106 & 29 & 89 \\
\hline 9 & Material Elétrico & 26 & 126 & 29 & 108 & 33 & 82 \\
\hline 10 & Equipamentos Eletrônicos & 36 & 97 & 41 & 79 & 38 & 76 \\
\hline 11 & Automóveis, caminhões e ônibus & 31 & 116 & 39 & 90 & 40 & 73 \\
\hline 12 & Peças e outros veículos & 23 & 133 & 27 & 114 & 30 & 87 \\
\hline 13 & Madeira e Mobiliário & 7 & 198 & 6 & 197 & 8 & 159 \\
\hline 14 & Celulose, Papel e Gráfica & 21 & 139 & 21 & 130 & 22 & 104 \\
\hline 15 & Indústria da Borracha & 37 & 97 & 37 & 95 & 34 & 79 \\
\hline 16 & Elementos Químicos & 24 & 129 & 22 & 125 & 27 & 95 \\
\hline 17 & Refino de Petróleo & 42 & 64 & 42 & 67 & 43 & 60 \\
\hline 18 & Químicos Diversos & 38 & 94 & 38 & 92 & 35 & 78 \\
\hline 19 & Farmacêuticos e Veterinários & 34 & 100 & 31 & 103 & 31 & 87 \\
\hline 20 & Artigos Plásticos & 35 & 100 & 35 & 96 & 28 & 91 \\
\hline 21 & Indústria Têxtil & 28 & 125 & 26 & 116 & 26 & 98 \\
\hline 22 & Artigos do Vestuário & 2 & 283 & 2 & 284 & 2 & 234 \\
\hline 23 & Calçados & 13 & 177 & 14 & 171 & 12 & 144 \\
\hline 24 & Indústria do Café & 9 & 188 & 10 & 187 & 9 & 154 \\
\hline 25 & Beneficiamento de Produtos Vegetais & 12 & 178 & 11 & 186 & 11 & 146 \\
\hline 26 & Abate de Animais & 5 & 211 & 5 & 203 & 6 & 169 \\
\hline 27 & Indústria de Laticínios & 10 & 187 & 9 & 188 & 14 & 133 \\
\hline 28 & Fabricação de Açúcar & 15 & 169 & 12 & 178 & 16 & 131 \\
\hline 29 & Fabricação de Óleos Vegetais & 14 & 170 & 13 & 176 & 15 & 132 \\
\hline 30 & Outros Produtos Alimentares & 16 & 158 & 17 & 158 & 17 & 130 \\
\hline 31 & Indústrias Diversas & 20 & 140 & 18 & 145 & 19 & 113 \\
\hline 32 & Serviços Industriais de Utilidade Pública & 33 & 103 & 33 & 98 & 36 & 78 \\
\hline 33 & Construção Civil & 30 & 119 & 28 & 110 & 23 & 103 \\
\hline 34 & Comércio & 8 & 192 & 8 & 189 & 7 & 166 \\
\hline 35 & Supermercados & 4 & 226 & 7 & 190 & 5 & 185 \\
\hline 36 & Transportes & 19 & 143 & 19 & 139 & 18 & 129 \\
\hline 37 & Comunicações & 25 & 127 & 32 & 101 & 32 & 82 \\
\hline 38 & Instituições Financeiras & 39 & 91 & 24 & 121 & 20 & 108 \\
\hline 39 & Serviços Prestados às Famílias & 6 & 211 & 4 & 213 & 4 & 206 \\
\hline 40 & Serviços Prestados às Empresas & 17 & 151 & 16 & 161 & 13 & 144 \\
\hline 41 & Aluguel de Imóveis & 43 & 46 & 43 & 64 & 42 & 62 \\
\hline 42 & Administração Pública & 11 & 181 & 15 & 167 & 10 & 146 \\
\hline 43 & Serviços Privados não-mercantis & 1 & 537 & 1 & 601 & 1 & 599 \\
\hline Mé & & & 153 & & 150 & & 128 \\
\hline
\end{tabular}


Tabela 30. Geração de empregos diretos (dir), indiretos (indir) e induzidos (indu) pela

variação da demanda final de um milhão de reais (metodologia tradicional).

\begin{tabular}{|c|c|c|c|c|c|c|c|c|c|}
\hline \multirow{2}{*}{ Setor } & \multicolumn{3}{|c|}{1990} & \multicolumn{3}{|c|}{1995} & \multicolumn{3}{|c|}{1999} \\
\hline & dir & indir & indu & dir & indir & indu & dir & indir & indu \\
\hline Agropecuária & 159 & 42 & 55 & 148 & 38 & 68 & 114 & 33 & 62 \\
\hline 2 Extrativa Mineral & 32 & 28 & 74 & 22 & 25 & 77 & 21 & 18 & 61 \\
\hline 3 Petróleo e gás & 5 & 24 & 60 & 3 & 19 & 73 & 3 & 11 & 61 \\
\hline 4 Minerais não-metálicos & 27 & 32 & 67 & 23 & 24 & 72 & 20 & 20 & 59 \\
\hline Siderurgia & 4 & 43 & 60 & 3 & 32 & 62 & 2 & 25 & 50 \\
\hline 6 Metalurgia de não-ferrosos & 5 & 30 & 56 & 4 & 20 & 58 & 3 & 20 & 48 \\
\hline Outros Produtos Metalúrgicos & 34 & 33 & 80 & 29 & 24 & 78 & 24 & 20 & 61 \\
\hline 8 Máquinas e Equipamentos & 17 & 29 & 74 & 14 & 18 & 74 & 13 & 14 & 63 \\
\hline 9 Material Elétrico & 24 & 33 & 70 & 13 & 25 & 69 & 8 & 22 & 53 \\
\hline 10 Equipamentos Eletrônicos & 14 & 26 & 57 & 8 & 17 & 55 & 8 & 16 & 52 \\
\hline 11 Automóveis, caminhões e ônibus & 6 & 40 & 70 & 4 & 25 & 61 & 3 & 21 & 49 \\
\hline 12 Peças e outros veículos & 18 & 35 & 80 & 13 & 26 & 75 & 9 & 21 & 57 \\
\hline 13 Madeira e Mobiliário & 58 & 61 & 79 & 60 & 57 & 81 & 50 & 42 & 68 \\
\hline 14 Celulose, Papel e Gráfica & 19 & 42 & 78 & 17 & 35 & 78 & 14 & 28 & 63 \\
\hline 15 Indústria da Borracha & 9 & 31 & 56 & 7 & 27 & 61 & 5 & 24 & 50 \\
\hline 16 Elementos Químicos & 5 & 66 & 59 & 5 & 54 & 67 & 3 & 36 & 56 \\
\hline 17 Refino de Petróleo & 1 & 18 & 44 & 1 & 12 & 54 & 1 & 11 & 49 \\
\hline 18 Químicos Diversos & 10 & 26 & 59 & 6 & 24 & 63 & 6 & 19 & 53 \\
\hline 19 Farmacêuticos e Veterinários & 8 & 33 & 60 & 8 & 27 & 67 & 7 & 23 & 58 \\
\hline 20 Artigos Plásticos & 20 & 19 & 60 & 16 & 14 & 66 & 20 & 14 & 58 \\
\hline 21 Indústria Têxtil & 23 & 44 & 58 & 16 & 37 & 62 & 11 & 36 & 51 \\
\hline 22 Artigos do Vestuário & 159 & 40 & 84 & 167 & 32 & 85 & 139 & 27 & 69 \\
\hline 23 Calçados & 48 & 54 & 76 & 53 & 43 & 76 & 50 & 32 & 62 \\
\hline 24 Indústria do Café & 5 & 122 & 61 & 8 & 110 & 69 & 7 & 88 & 60 \\
\hline 25 Beneficiamento de Produtos Vegetais & 15 & 103 & 61 & 13 & 104 & 69 & 12 & 75 & 59 \\
\hline 26 Abate de Animais & 9 & 140 & 62 & 10 & 122 & 71 & 9 & 98 & 61 \\
\hline 27 Indústria de Laticínios & 6 & 122 & 59 & 6 & 114 & 68 & 6 & 72 & 55 \\
\hline 28 Fabricação de Açúcar & 12 & 93 & 63 & 13 & 92 & 73 & 9 & 62 & 60 \\
\hline 29 Fabricação de Óleos Vegetais & 3 & 108 & 60 & 2 & 108 & 66 & 2 & 74 & 56 \\
\hline 30 Outros Produtos Alimentares & 20 & 70 & 68 & 20 & 67 & 72 & 19 & 51 & 60 \\
\hline 31 Indústrias Diversas & 41 & 29 & 70 & 39 & 27 & 80 & 29 & 23 & 61 \\
\hline 32 Serviços Industriais de Utilidade Pública & 10 & 17 & 76 & 7 & 9 & 82 & 4 & 8 & 66 \\
\hline 33 Construção Civil & 26 & 28 & 65 & 27 & 18 & 65 & 28 & 16 & 59 \\
\hline 34 Comércio & 90 & 16 & 87 & 84 & 14 & 91 & 74 & 15 & 78 \\
\hline 35 Supermercados & 109 & 20 & 98 & 82 & 15 & 93 & 92 & 17 & 75 \\
\hline 36 Transportes & 44 & 20 & 79 & 43 & 16 & 80 & 39 & 19 & 71 \\
\hline 37 Comunicações & 34 & 11 & 83 & 14 & 8 & 79 & 6 & 8 & 69 \\
\hline 38 Instituições Financeiras & 15 & 7 & 70 & 11 & 13 & 97 & 9 & 15 & 84 \\
\hline 39 Serviços Prestados às Famílias & 84 & 32 & 95 & 96 & 26 & 90 & 100 & 23 & 82 \\
\hline 40 Serviços Prestados às Empresas & 47 & 15 & 89 & 52 & 13 & 96 & 49 & 12 & 82 \\
\hline 41 Aluguel de Imóveis & 2 & 5 & 39 & 2 & 2 & 59 & 2 & 2 & 58 \\
\hline 42 Administração Pública & 36 & 18 & 126 & 28 & 22 & 117 & 28 & 17 & 101 \\
\hline 43 Serviços Privados não-mercantis & 397 & 6 & 134 & 465 & 5 & 131 & 483 & 4 & 113 \\
\hline Média & 40 & 42 & 71 & 39 & 36 & 75 & 36 & 29 & 63 \\
\hline
\end{tabular}


Tabela 31. Geração de empregos diretos (dir), indiretos (indir), induzidos (indu) e total dos setores (nova proposta metodológica).

\begin{tabular}{|c|c|c|c|c|c|c|c|c|c|c|c|}
\hline \multirow{2}{*}{\multicolumn{2}{|c|}{ Setor }} & \multicolumn{5}{|c|}{$1995 n$} & \multicolumn{5}{|c|}{ 1999n } \\
\hline & & \multirow{2}{*}{$\begin{array}{r}\text { ordem } \\
3\end{array}$} & \multirow{2}{*}{$\frac{\operatorname{dir}}{148}$} & \multirow{2}{*}{$\begin{array}{r}\text { indir } \\
38\end{array}$} & \multirow{2}{*}{$\begin{array}{r}\text { indu } \\
60\end{array}$} & \multirow{2}{*}{$\begin{array}{r}\text { total } \\
247\end{array}$} & \multirow{2}{*}{ ordem } & \multirow{2}{*}{$\begin{array}{r}\operatorname{dir} \\
114\end{array}$} & \multirow{2}{*}{$\begin{array}{r}\text { indir } \\
37\end{array}$} & \multirow{2}{*}{$\begin{array}{r}\text { indu } \\
86\end{array}$} & \multirow{2}{*}{$\frac{\text { tota }}{237}$} \\
\hline 1 & Agropecuária & & & & & & & & & & \\
\hline 2 & Extrativa Mineral & 23 & 22 & 25 & 74 & 121 & 25 & 21 & 22 & 84 & 127 \\
\hline 3 & Petróleo e gás & 37 & 3 & 19 & 68 & 89 & 41 & 3 & 13 & 81 & 97 \\
\hline 4 & Minerais não-metálicos & 25 & 23 & 24 & 67 & 114 & 26 & 20 & 24 & 82 & 127 \\
\hline 5 & Siderurgia & 34 & 3 & 32 & 58 & 93 & 38 & 2 & 29 & 70 & 101 \\
\hline 6 & Metalurgia de não-ferrosos & 40 & 4 & 20 & 53 & 77 & 40 & 3 & 26 & 69 & 98 \\
\hline 7 & Outros Produtos Metalúrgicos & 20 & 29 & 24 & 76 & 130 & 22 & 24 & 25 & 86 & 135 \\
\hline 8 & Máquinas e Equipamentos & 30 & 14 & 18 & 70 & 102 & 31 & 13 & 18 & 86 & 117 \\
\hline 9 & Material Elétrico & 29 & 13 & 25 & 66 & 104 & 32 & 8 & 28 & 76 & 112 \\
\hline 10 & Equipamentos Eletrônicos & 41 & 8 & 17 & 50 & 75 & 37 & 8 & 21 & 73 & 102 \\
\hline 11 & Automóveis, caminhões e ônibus & 39 & 4 & 25 & 58 & 87 & 35 & 3 & 29 & 72 & 104 \\
\hline 12 & Peças e outros veículos & 27 & 13 & 26 & 72 & 111 & 28 & 9 & 28 & 81 & 119 \\
\hline 13 & Madeira e Mobiliário & 6 & 60 & 57 & 78 & 195 & 7 & 50 & 49 & 96 & 194 \\
\hline 14 & Celulose, Papel e Gráfica & 21 & 17 & 35 & 77 & 129 & 20 & 14 & 35 & 90 & 138 \\
\hline 15 & Indústria da Borracha & 36 & 7 & 27 & 56 & 90 & 33 & 5 & 30 & 71 & 107 \\
\hline 16 & Elementos Químicos & 24 & 5 & 54 & 60 & 118 & 27 & 3 & 39 & 76 & 119 \\
\hline 17 & Refino de Petróleo & 42 & 1 & 12 & 48 & 61 & 42 & 1 & 14 & 67 & 82 \\
\hline 18 & Químicos Diversos & 38 & 6 & 24 & 60 & 89 & 36 & 6 & 24 & 74 & 104 \\
\hline 19 & Farmacêuticos e Veterinários & 31 & 8 & 27 & 64 & 99 & 30 & 7 & 29 & 83 & 118 \\
\hline 20 & Artigos Plásticos & 35 & 16 & 14 & 61 & 91 & 29 & 20 & 18 & 81 & 118 \\
\hline 21 & Indústria Têxtil & 26 & 16 & 37 & 58 & 112 & 23 & 11 & 43 & 75 & 129 \\
\hline 22 & Artigos do Vestuário & 2 & 167 & 32 & 86 & 285 & 3 & 139 & 33 & 98 & 269 \\
\hline 23 & Calçados & 14 & 53 & 43 & 73 & 169 & 11 & 50 & 39 & 89 & 178 \\
\hline 24 & Indústria do Café & 10 & 8 & 110 & 62 & 180 & 8 & 7 & 93 & 83 & 183 \\
\hline 25 & Beneficiamento de Produtos Vegetais & 9 & 13 & 104 & 64 & 181 & 10 & 12 & 83 & 85 & 180 \\
\hline 26 & Abate de Animais & 5 & 10 & 122 & 65 & 197 & 6 & 9 & 106 & 88 & 203 \\
\hline 27 & Indústria de Laticínios & 8 & 6 & 114 & 61 & 181 & 16 & 6 & 78 & 77 & 161 \\
\hline 28 & Fabricação de Açúcar & 11 & 13 & 92 & 69 & 174 & 15 & 9 & 68 & 85 & 163 \\
\hline 29 & Fabricação de Óleos Vegetais & 13 & 2 & 108 & 60 & 170 & 14 & 2 & 81 & 81 & 164 \\
\hline 30 & Outros Produtos Alimentares & 16 & 20 & 67 & 68 & 154 & 13 & 19 & 59 & 88 & 166 \\
\hline 31 & Indústrias Diversas & 18 & 39 & 27 & 77 & 142 & 19 & 29 & 28 & 86 & 143 \\
\hline 32 & $\begin{array}{l}\text { Serviços Industriais de Utilidade } \\
\text { Pública }\end{array}$ & 32 & 7 & 9 & 81 & 97 & 39 & 4 & 9 & 87 & 100 \\
\hline 33 & Construção Civil & 28 & 27 & 18 & 59 & 104 & 24 & 28 & 19 & 81 & 129 \\
\hline 34 & Comércio & 7 & 84 & 14 & 91 & 189 & 2 & 129 & 30 & 183 & 342 \\
\hline 35 & Supermercados & 17 & 13 & 72 & 61 & 146 & 18 & 12 & 66 & 76 & 154 \\
\hline 36 & Transportes & 19 & 43 & 16 & 80 & 139 & 17 & 39 & 24 & 98 & 161 \\
\hline 37 & Comunicações & 33 & 14 & 8 & 75 & 96 & 34 & 6 & 9 & 91 & 106 \\
\hline 38 & Instituições Financeiras & 22 & 11 & 13 & 98 & 122 & 21 & 9 & 17 & 111 & 136 \\
\hline 39 & Serviços Prestados às Famílias & 4 & 96 & 26 & 91 & 213 & 4 & 100 & 28 & 112 & 240 \\
\hline 40 & Serviços Prestados às Empresas & 15 & 52 & 13 & 98 & 163 & 12 & 49 & 15 & 110 & 174 \\
\hline 41 & Aluguel de Imóveis & 43 & 2 & 2 & 47 & 52 & 43 & 2 & 2 & 76 & 80 \\
\hline 42 & Administração Pública & 12 & 28 & 22 & 123 & 173 & 9 & 28 & 20 & 135 & 183 \\
\hline & Serviços Privados não-mercantis & 1 & 465 & 5 & 139 & 609 & & 483 & 4 & 147 & 635 \\
\hline & & & 37 & 38 & 71 & 146 & & 35 & 35 & 89 & 159 \\
\hline
\end{tabular}

dir = empregos diretos, indir = empregos indiretos, indu = empregos induzidos 


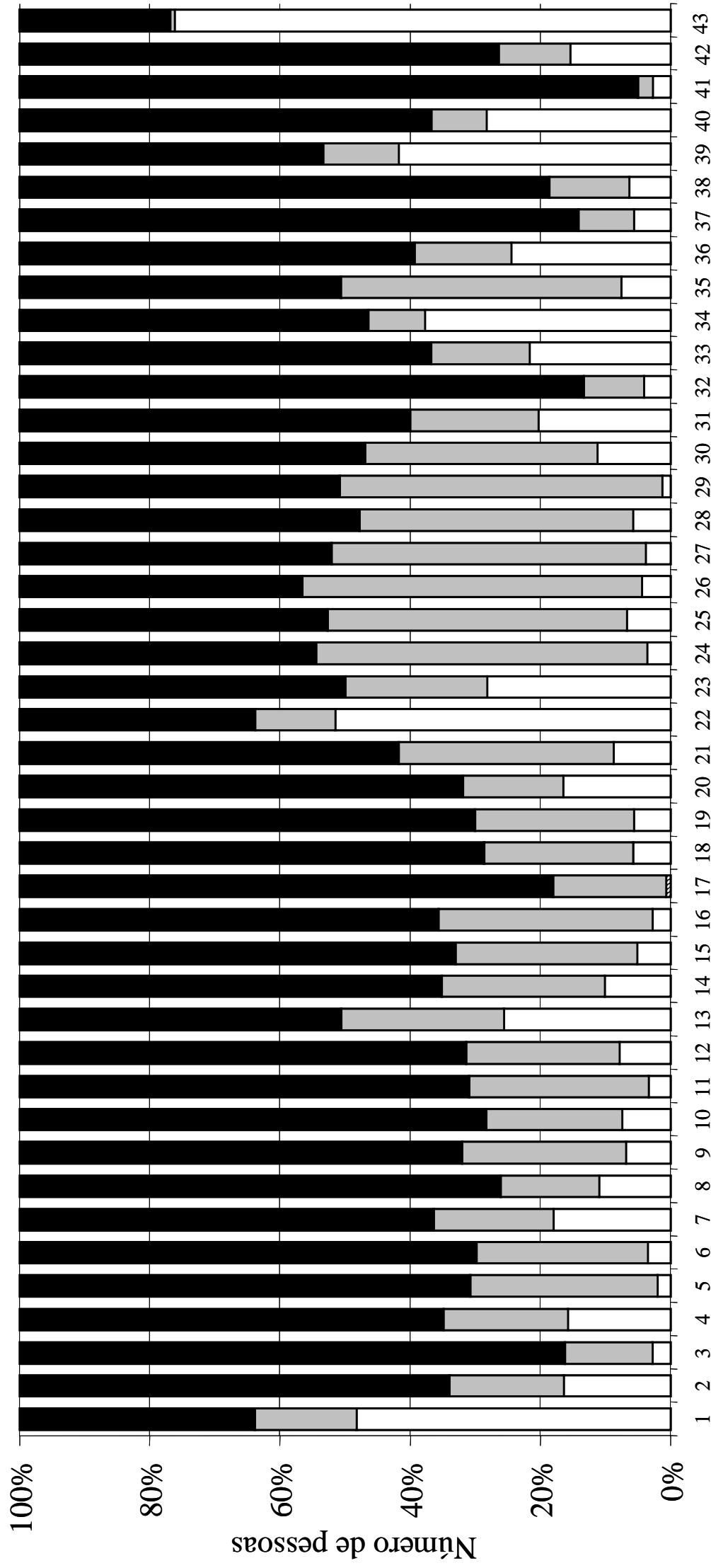


Os setores que sofrem maior impacto relativo na geração de empregos devido a variações da produção do setor 35-Supermercados podem ser identificados analisando-se os valores dos multiplicadores de emprego tipos I e II desagregados do setor, apresentados na Tabela 32 (metodologia tradicional) e Tabela 33 (nova proposta metodológica). Os resultados da decomposição do multiplicador de emprego são interpretados da seguinte forma: o multiplicador de emprego tipo II do ano de 1999, Tabela 33, indica que para cada emprego gerado no setor supermercadista seriam gerados outros 13,24 postos de trabalho na economia como um todo. Deste valor total, 3,66 vagas surgiriam no setor 1-Agropecuária considerando os efeitos diretos, indiretos e induzidos pelo aumento de um milhão de reais da demanda final dos 35-Supermercados. O multiplicador tipo I é interpretado do mesmo modo, porém, engloba os efeitos diretos e indiretos do aumento da demanda final.

Observando os resultados da Tabela 32, nota-se que em 1990 os setores que sofreriam maior influência sobre o emprego total, considerando os efeitos diretos, indiretos e induzidos dado o aumento de produção do setor 35-Supermercados seriam, excluindo o próprio setor, respectivamente: 1-Agropecuária, 34-Comércio, 39-Serviços prestados às famílias, 43-Serviços privados não-mercantis e 22-Artigos do vestuário. Os resultados para o ano de 1995 indicam que os setores seriam: 1-Agropecuária, 39Serviços prestados às famílias, 34-Comércio, 43-Serviços privados não-mercantis e 40Serviços prestados às empresas. No ano de 1999, o maior impacto em termos de geração de empregos era sentido, respectivamente, em: 1-Agropecuária, 39-Serviços prestados às famílias, 34-Comércio, 43-Serviços privados não-mercantis e 40-Serviços prestados às empresas.

Os resultados obtidos pela metodologia tradicional mostram o aumento da importância dos 35-Supermercados para geração de empregos principalmente para os setores 1-Agropecuária e 39-Serviços prestados às famílias, notadamente por efeito induzido (multiplicador tipo II), no período 1990/95. Posteriormente, cresceu a importância da influência do setor supermercadista sobre o emprego no setor 40Serviços prestados às empresas. 
Os valores calculados utilizando a nova proposta metodológica, resumidos na Tabela 33 são diferentes daqueles obtidos pela abordagem anteriormente definida, denominada metodologia tradicional. Analisando os valores, nota-se que o impacto em termos de empregos gerados, considerando-se os efeitos diretos e indiretos do aumento das vendas dos supermercados, seria maior em 1995n nos setores: 1-Agropecuária, 34Comércio, 30-Outros produtos alimentares, 36-Transportes, 22-Artigos do vestuário, 40Serviços prestados às empresas e 25-Beneficiamento de produtos vegetais. Para o ano de 1999n, os resultados indicam os setores 1-Agropecuária, 34-Comércio, 30-Outros produtos alimentares, 40-Serviços prestados às empresas, 36-Transportes, 22-Artigos do vestuário e 25-Beneficiamento de produtos vegetais.

Os resultados da nova proposta metodológica indicam a grande importância do setor 35-Supermercados para a geração de empregos na produção agropecuária e indústria de alimentos por efeito indireto, além de outras atividades do comércio e transporte, principalmente por efeito induzido.

A análise do impacto relativo do aumento das vendas dos supermercados sobre o emprego na economia permite constatar que diferentes setores, ligados à produção e processamento de alimentos, serviços prestados às empresas (como seguros, propaganda e consultoria), transporte de mercadorias e vestuário, sofreriam fortes impactos positivos na geração de postos de trabalho. Além disso, cresceu o número de setores no período 1995/99 que apresentariam impactos importantes sobre o emprego, pois o setor 35Supermercados passou a abrigar maior número de lojas de hipermercados. Estas comercializam um grande número de itens não-alimentares, aumentando a relação com diferentes tipos de indústrias como 22-Artigos do vestuário, 23-Calçados e 20-Artigos plásticos, que tiveram aumento da participação nos multiplicadores de empregos dos supermercados conforme os valores da Tabela 33. 
Tabela 32. Decomposição dos multiplicadores de emprego tipos I e II do setor 35Supermercados (metodologia tradicional).

\begin{tabular}{|c|c|c|c|c|c|c|c|c|c|}
\hline \multirow{2}{*}{ Setor } & \multicolumn{3}{|c|}{1990} & \multicolumn{3}{|c|}{1995} & \multicolumn{3}{|c|}{1999} \\
\hline & ordem & I & II & ordem & I & II & ordem & I & II \\
\hline Agropecuária & 2 & 0,010 & 0,266 & 2 & 0,011 & 0,352 & 2 & 0,007 & 0,219 \\
\hline 2 Extrativa Mineral & 32 & 0,000 & 0,002 & 36 & 0,000 & 0,001 & 34 & 0,000 & 0,001 \\
\hline 3 Petróleo e gás & 40 & 0,000 & 0,001 & 43 & 0,000 & 0,000 & 40 & 0,000 & 0,001 \\
\hline 4 Minerais não-metálicos & 26 & 0,001 & 0,004 & 27 & 0,001 & 0,004 & 26 & 0,001 & 0,003 \\
\hline 5 Siderurgia & 37 & 0,000 & 0,001 & 40 & 0,000 & 0,001 & 42 & 0,000 & 0,000 \\
\hline 6 Metalurgia de não-ferrosos & 41 & 0,000 & 0,001 & 42 & 0,000 & 0,000 & 43 & 0,000 & 0,000 \\
\hline 7 Outros Produtos Metalúrgicos & 15 & 0,002 & 0,011 & 15 & 0,003 & 0,011 & 17 & 0,002 & 0,007 \\
\hline 8 Máquinas e Equipamentos & 23 & 0,002 & 0,006 & 23 & 0,003 & 0,006 & 24 & 0,002 & 0,004 \\
\hline 9 Material Elétrico & 25 & 0,001 & 0,005 & 28 & 0,001 & 0,003 & 30 & 0,000 & 0,001 \\
\hline 10 Equipamentos Eletrônicos & 30 & 0,000 & 0,003 & 30 & 0,000 & 0,002 & 32 & 0,000 & 0,001 \\
\hline 11 Automóveis, caminhões e ônibus & 34 & 0,000 & 0,001 & 33 & 0,000 & 0,002 & 33 & 0,000 & 0,001 \\
\hline 12 Peças e outros veículos & 24 & 0,001 & 0,005 & 26 & 0,000 & 0,004 & 29 & 0,000 & 0,002 \\
\hline 13 Madeira e Mobiliário & 12 & 0,002 & 0,014 & 11 & 0,003 & 0,016 & 13 & 0,002 & 0,010 \\
\hline 14 Celulose, Papel e Gráfica & 10 & 0,014 & 0,021 & 9 & 0,011 & 0,017 & 11 & 0,008 & 0,012 \\
\hline 15 Indústria da Borracha & 38 & 0,000 & 0,001 & 38 & 0,000 & 0,001 & 38 & 0,000 & 0,001 \\
\hline 16 Elementos Químicos & 35 & 0,000 & 0,001 & 35 & 0,000 & 0,001 & 35 & 0,000 & 0,001 \\
\hline 17 Refino de Petróleo & 36 & 0,000 & 0,001 & 37 & 0,000 & 0,001 & 37 & 0,000 & 0,001 \\
\hline 18 Químicos Diversos & 27 & 0,001 & 0,004 & 31 & 0,000 & 0,002 & 28 & 0,000 & 0,002 \\
\hline 19 Farmacêuticos e Veterinários & 31 & 0,000 & 0,002 & 29 & 0,000 & 0,003 & 27 & 0,000 & 0,002 \\
\hline 20 Artigos I & 21 & 0,004 & 0,007 & 25 & 0,002 & 0,005 & 20 & 0,002 & 0,005 \\
\hline 21 Indústria Têxtil & 11 & 0,002 & 0,015 & 18 & 0,001 & 0,009 & 22 & 0,000 & 0,004 \\
\hline 22 Artigos do Vestuário & 6 & 0,001 & 0,064 & 7 & 0,000 & 0,055 & 8 & 0,000 & 0,030 \\
\hline 23 Calçados & 18 & 0,000 & 0,008 & 22 & 0,000 & 0,006 & 25 & 0,000 & 0,004 \\
\hline 24 Indústria do Café & 43 & 0,000 & 0,000 & 39 & 0,000 & 0,001 & 39 & 0,000 & 0,001 \\
\hline 25 Beneficiamento de Produtos Vegetais & 22 & 0,000 & 0,006 & 20 & 0,000 & 0,007 & 18 & 0,000 & 0,006 \\
\hline 26 Abate de Animais & 28 & 0,000 & 0,004 & 24 & 0,000 & 0,005 & 23 & 0,000 & 0,004 \\
\hline 27 Indústria de Laticínios & 39 & 0,000 & 0,001 & 32 & 0,000 & 0,002 & 31 & 0,000 & 0,001 \\
\hline 28 Fabricação de Açúcar & 33 & 0,000 & 0,002 & 34 & 0,000 & 0,001 & 36 & 0,000 & 0,001 \\
\hline 29 Fabricação de Óleos Vegetais & 42 & 0,000 & 0,000 & 41 & 0,000 & 0,001 & 41 & 0,000 & 0,000 \\
\hline 30 Outros Produtos Alimentares & 13 & 0,000 & 0,012 & 12 & 0,000 & 0,016 & 10 & 0,000 & 0,013 \\
\hline 31 Indústrias Diversas & 20 & 0,002 & 0,007 & 21 & 0,002 & 0,007 & 21 & 0,001 & 0,005 \\
\hline $\begin{array}{l}32 \text { Serviços Industriais de Utilidade } \\
\text { Pública }\end{array}$ & 16 & 0,003 & 0,009 & 17 & 0,004 & 0,009 & 19 & 0,002 & 0,005 \\
\hline 33 Construção Civil & 19 & 0,004 & 0,007 & 14 & 0,007 & 0,011 & 14 & 0,006 & 0,010 \\
\hline 34 Comércio & 3 & 0,029 & 0,196 & 4 & 0,027 & 0,201 & 4 & 0,026 & 0,149 \\
\hline 35 Supermercados & 1 & 1,000 & 1,014 & 1 & 1,000 & 1,019 & 1 & 1,000 & 1,014 \\
\hline 36 Transportes & 8 & 0,014 & 0,049 & 8 & 0,014 & 0,054 & 7 & 0,009 & 0,044 \\
\hline 37 Comunicações & 14 & 0,005 & 0,011 & 16 & 0,006 & 0,010 & 16 & 0,004 & 0,007 \\
\hline 38 Instituições Financeiras & 17 & 0,002 & 0,008 & 13 & 0,006 & 0,014 & 12 & 0,006 & 0,012 \\
\hline 39 Serviços Prestados às Famílias & 4 & 0,024 & 0,155 & 3 & 0,021 & 0,236 & 3 & 0,017 & 0,184 \\
\hline 40 Serviços Prestados às Empresas & 7 & 0,038 & 0,051 & 6 & 0,048 & 0,065 & 6 & 0,073 & 0,092 \\
\hline 41 Aluguel de Imóveis & 29 & 0,001 & 0,004 & 19 & 0,002 & 0,008 & 15 & 0,002 & 0,007 \\
\hline 42 Administração Pública & 9 & 0,015 & 0,023 & 10 & 0,010 & 0,017 & 9 & 0,009 & 0,013 \\
\hline 43 Serviços Privados não-mercantis & 5 & 0,000 & 0,077 & 5 & 0,000 & 0,137 & 5 & 0,000 & 0,118 \\
\hline Total & & 1,180 & 2,08 & & 1,186 & 2,322 & & 1,183 & 1,997 \\
\hline
\end{tabular}


Tabela 33. Decomposição dos multiplicadores de emprego tipos I e II do setor 35Supermercados (nova proposta metodológica).

\begin{tabular}{|c|c|c|c|c|c|c|c|c|}
\hline \multirow{3}{*}{ Setor } & \multicolumn{4}{|c|}{$1995 n$} & \multicolumn{4}{|c|}{$1999 n$} \\
\hline & \multicolumn{2}{|c|}{ Tipo I } & \multicolumn{2}{|c|}{ Tipo II } & \multicolumn{2}{|c|}{ Tipo I } & \multicolumn{2}{|c|}{ Tipo II } \\
\hline & ordem & valor & ordem & valor & ordem & valor & ordem & valor \\
\hline 1 Agropecuária & 1 & 3,578 & 1 & 4,980 & 1 & 3,154 & 1 & 4,666 \\
\hline 2 Extrativa Mineral & 33 & 0,008 & 35 & 0,012 & 33 & 0,008 & 36 & 0,013 \\
\hline 3 Petróleo e gás & 41 & 0,001 & 43 & 0,002 & 36 & 0,004 & 39 & 0,008 \\
\hline 4 Minerais não-metálicos & 18 & 0,023 & 22 & 0,036 & 19 & 0,021 & 28 & 0,035 \\
\hline 5 Siderurgia & 37 & 0,004 & 40 & 0,006 & 39 & 0,003 & 42 & 0,005 \\
\hline 6 Metalurgia de não-ferrosos & 39 & 0,002 & 42 & 0,004 & 40 & 0,002 & 43 & 0,004 \\
\hline 7 Outros Produtos Metalúrgicos & 13 & 0,052 & 13 & 0,084 & 13 & 0,044 & 15 & 0,078 \\
\hline 8 Máquinas e Equipamentos & 22 & 0,018 & 25 & 0,030 & 25 & 0,015 & 29 & 0,030 \\
\hline 9 Material Elétrico & 19 & 0,021 & 24 & 0,032 & 30 & 0,012 & 31 & 0,020 \\
\hline 10 Equipamentos Eletrônicos & 26 & 0,016 & 30 & 0,026 & 31 & 0,011 & 32 & 0,017 \\
\hline 11 Automóveis, caminhões e ônibus & 42 & 0,000 & 39 & 0,006 & 42 & 0,000 & 40 & 0,007 \\
\hline 12 Peças e outros veículos & 34 & 0,005 & 33 & 0,021 & 38 & 0,003 & 34 & 0,016 \\
\hline 13 Madeira e Mobiliário & 20 & 0,020 & 15 & 0,075 & 23 & 0,017 & 14 & 0,078 \\
\hline 14 Celulose, Papel e Gráfica & 9 & 0,086 & 11 & 0,111 & 9 & 0,092 & 11 & 0,127 \\
\hline 15 Indústria da Borracha & 40 & 0,002 & 41 & 0,005 & 41 & 0,002 & 41 & 0,006 \\
\hline 16 Elementos Químicos & 35 & 0,005 & 37 & 0,010 & 34 & 0,006 & 37 & 0,013 \\
\hline 17 Refino de Petróleo & 36 & 0,005 & 38 & 0,008 & 35 & 0,005 & 38 & 0,010 \\
\hline 18 Químicos Diversos & 23 & 0,017 & 31 & 0,025 & 18 & 0,023 & 27 & 0,036 \\
\hline 19 Farmacêuticos e Veterinários & 14 & 0,052 & 16 & 0,063 & 15 & 0,039 & 18 & 0,055 \\
\hline 20 Artigos Plásticos & 21 & 0,019 & 27 & 0,029 & 17 & 0,026 & 23 & 0,043 \\
\hline 21 Indústria Têxtil & 17 & 0,024 & 18 & 0,056 & 22 & 0,019 & 20 & 0,046 \\
\hline 22 Artigos do Vestuário & 6 & 0,127 & 6 & 0,350 & 7 & 0,139 & 8 & 0,350 \\
\hline 23 Calçados & 28 & 0,013 & 21 & 0,037 & 20 & 0,020 & 21 & 0,044 \\
\hline 24 Indústria do Café & 31 & 0,011 & 34 & 0,015 & 28 & 0,012 & 33 & 0,016 \\
\hline 25 Beneficiamento de Produtos Vegetais & 8 & 0,112 & 10 & 0,141 & 8 & 0,129 & 10 & 0,168 \\
\hline 26 Abate de Animais & 12 & 0,057 & 14 & 0,079 & 11 & 0,058 & 13 & 0,087 \\
\hline 27 Indústria de Laticínios & 16 & 0,035 & 20 & 0,041 & 14 & 0,042 & 19 & 0,050 \\
\hline 28 Fabricação de Açúcar & 24 & 0,017 & 32 & 0,023 & 24 & 0,016 & 30 & 0,022 \\
\hline 29 Fabricação de Óleos Vegetais & 32 & 0,009 & 36 & 0,011 & 32 & 0,010 & 35 & 0,013 \\
\hline 30 Outros Produtos Alimentares & 4 & 0,230 & 8 & 0,293 & 4 & 0,261 & 9 & 0,348 \\
\hline 31 Indústrias Diversas & 15 & 0,037 & 17 & 0,058 & 16 & 0,034 & 17 & 0,057 \\
\hline 32 Serviços Industriais de Utilidade Pública & 27 & 0,015 & 23 & 0,035 & 27 & 0,013 & 26 & 0,037 \\
\hline 33 Construção Civil & 29 & 0,013 & 26 & 0,030 & 26 & 0,014 & 24 & 0,040 \\
\hline 34 Comércio & 3 & 0,379 & 2 & 1,092 & 3 & 0,888 & 2 & 2,447 \\
\hline 35 Supermercados & 2 & 1,000 & 3 & 1,078 & 2 & 1,000 & 4 & 1,100 \\
\hline 36 Transportes & 5 & 0,181 & 7 & 0,349 & 6 & 0,200 & 6 & 0,467 \\
\hline 37 Comunicações & 30 & 0,012 & 28 & 0,028 & 29 & 0,012 & 25 & 0,038 \\
\hline 38 Instituições Financeiras & 25 & 0,017 & 19 & 0,050 & 21 & 0,019 & 16 & 0,058 \\
\hline 39 Serviços Prestados às Famílias & 10 & 0,085 & 4 & 0,970 & 10 & 0,068 & 3 & 1,252 \\
\hline 40 Serviços Prestados às Empresas & 7 & 0,121 & 9 & 0,194 & 5 & 0,205 & 7 & 0,370 \\
\hline 41 Aluguel de Imóveis & 38 & 0,003 & 29 & 0,026 & 37 & 0,003 & 22 & 0,044 \\
\hline 42 Administração Pública & 11 & 0,062 & 12 & 0,089 & 12 & 0,055 & 12 & 0,088 \\
\hline 43 Serviços Privados não-mercantis & 43 & 0,000 & 5 & 0,562 & 43 & 0,000 & 5 & 0,831 \\
\hline Total & & 6,494 & & 11,169 & & 6,702 & & 13,240 \\
\hline
\end{tabular}


Os resultados da pesquisa sobre o número total de empregos gerados para uma variação da demanda final de um bilhão de reais do setor 35-Supermercados e em quais setores eles surgem constam das Tabelas 34 e 35 . A Tabela 34 apresenta os valores para os anos de 1990, 1995 e 1999 com o setor supermercadista desagregado pela metodologia tradicional e a Tabela 35 possui os resultados da nova proposta metodológica para o período 1995/99.

A análise dos resultados resumidos na Tabela 34 indica que a maior parte dos empregos gerados (cerca de 50\%) pelo aumento da demanda final do setor 35Supermercados está na própria atividade, em segundo lugar está a 1-Agropecuária e em seguida 39-Serviços prestados às famílias. Porém, estes valores não levam em consideração os bens comercializados pelo setor supermercadista, pois as indústrias de alimentos não apresentam destaque na geração de empregos.

Os resultados da Tabela 35 incluem os efeitos do aumento das vendas dos produtos. Nota-se que a maior parte dos empregos gerados se encontra no setor 1Agropecuária, aproximadamente 54 mil de 153 mil empregos gerados pelo aumento de um bilhão de reais da produção do setor supermercadista, em segundo lugar está o setor 34-Comércio e em terceiro o próprio setor 35-Supermercados. A participação no número de empregos gerados também é importante para os setores 43-Serviços privados nãomercantis, 39-Serviços prestados às famílias, 36-Transportes, 40-Serviços prestados às empresas, 30-Outros produtos alimentares, 22-Artigos do vestuário, 14-Celulose, papel e gráfica e 25-Beneficiamento de produtos vegetais. Os empregos dos setores de serviços são gerados principalmente por efeito induzido, enquanto que nos outros setores principalmente por efeito indireto.

Os resultados das duas metodologias indicam que houve diminuição do número total de empregos gerados em diversas atividades, principalmente no setor 1Agropecuária, no qual surge a maior parte dos empregos quando do aumento da demanda final dos 35-Supermercados. Pode-se observar na Tabela 35 que concomitantemente os setores de serviços passam a ter uma importância maior no número de postos de trabalho gerados. 
Tabela 34. Geração de empregos por setor dada uma variação da demanda final de $\mathrm{R}$ \$ 1 bilhão do setor 35-Supermercados (metodologia tradicional).

\begin{tabular}{|c|c|c|c|c|c|c|}
\hline \multirow{2}{*}{ Setor } & \multicolumn{2}{|c|}{1990} & \multicolumn{2}{|c|}{1995} & \multicolumn{2}{|c|}{1999} \\
\hline & empregos & $\%$ & empregos & $\%$ & empregos & $\%$ \\
\hline 1 Agropecuária & 28.959 & 12,8 & 28.759 & 15,1 & 20.293 & $\overline{11,0}$ \\
\hline 2 Extrativa Mineral & 209 & 0,1 & 105 & 0,1 & 85 & 0,0 \\
\hline 3 Petróleo e gás & 94 & 0,0 & 25 & 0,0 & 54 & 0,0 \\
\hline 4 Minerais não-metálicos & 451 & 0,2 & 322 & 0,2 & 244 & 0,1 \\
\hline 5 Siderurgia & 134 & 0,1 & 74 & 0,0 & 44 & 0,0 \\
\hline 6 Metalurgia de não-ferrosos & 75 & 0,0 & 37 & 0,0 & 32 & 0,0 \\
\hline 7 Outros Produtos Metalúrgicos & 1.144 & 0,5 & 885 & 0,5 & 622 & 0,3 \\
\hline 8 Máquinas e Equipamentos & 631 & 0,3 & 453 & 0,2 & 336 & 0,2 \\
\hline 9 Material Elétrico & 540 & 0,2 & 263 & 0,1 & 123 & 0,1 \\
\hline 10 Equipamentos Eletrônicos & 373 & 0,2 & 196 & 0,1 & 89 & 0,0 \\
\hline 11 Automóveis, caminhões e ônibus & 154 & 0,1 & 127 & 0,1 & 86 & 0,0 \\
\hline 12 Peças e outros veículos & 562 & 0,2 & 352 & 0,2 & 187 & 0,1 \\
\hline 13 Madeira e Mobiliário & 1.568 & 0,7 & 1.322 & 0,7 & 969 & 0,5 \\
\hline 14 Celulose, Papel e Gráfica & 2.241 & 1,0 & 1.398 & 0,7 & 1.148 & 0,6 \\
\hline 15 Indústria da Borracha & 134 & 0,1 & 79 & 0,0 & 59 & 0,0 \\
\hline 16 Elementos Químicos & 150 & 0,1 & 121 & 0,1 & 85 & 0,0 \\
\hline 17 Refino de Petróleo & 147 & 0,1 & 89 & 0,0 & 67 & 0,0 \\
\hline 18 Químicos Diversos & 416 & 0,2 & 178 & 0,1 & 194 & 0,1 \\
\hline 19 Farmacêuticos e Veterinários & 234 & 0,1 & 238 & 0,1 & 209 & 0,1 \\
\hline 20 Artigos Plásticos & 752 & 0,3 & 384 & 0,2 & 439 & 0,2 \\
\hline 21 Indústria Têxtil & 1.629 & 0,7 & 714 & 0,4 & 405 & 0,2 \\
\hline 22 Artigos do Vestuário & 6.968 & 3,1 & 4.458 & 2,3 & 2.791 & 1,5 \\
\hline 23 Calçados & 860 & 0,4 & 488 & 0,3 & 334 & 0,2 \\
\hline 24 Indústria do Café & 34 & 0,0 & 74 & 0,0 & 55 & 0,0 \\
\hline 25 Beneficiamento de Produtos Vegetais & 632 & 0,3 & 580 & 0,3 & 521 & 0,3 \\
\hline 26 Abate de Animais & 405 & 0,2 & 434 & 0,2 & 392 & 0,2 \\
\hline 27 Indústria de Laticínios & 130 & 0,1 & 129 & 0,1 & 105 & 0,1 \\
\hline 28 Fabricação de Açúcar & 166 & 0,1 & 122 & 0,1 & 83 & 0,0 \\
\hline 29 Fabricação de Óleos Vegetais & 47 & 0,0 & 44 & 0,0 & 46 & 0,0 \\
\hline 30 Outros Produtos Alimentares & 1.251 & 0,6 & 1.283 & 0,7 & 1.158 & 0,6 \\
\hline 31 Indústrias Diversas & 756 & 0,3 & 572 & 0,3 & 418 & 0,2 \\
\hline 32 Serviços Industriais de Utilidade Pública & 956 & 0,4 & 763 & 0,4 & 507 & 0,3 \\
\hline 33 Construção Civil & 789 & 0,3 & 930 & 0,5 & 926 & 0,5 \\
\hline 34 Comércio & 21.344 & 9,4 & 16.416 & 8,6 & 13.757 & 7,4 \\
\hline 35 Supermercados & 110.190 & 48,7 & 83.315 & 43,9 & 93.779 & 50,8 \\
\hline 36 Transportes & 5.315 & 2,4 & 4.443 & 2,3 & 4.052 & 2,2 \\
\hline 37 Comunicações & 1.153 & 0,5 & 777 & 0,4 & 656 & 0,4 \\
\hline 38 Instituições Financeiras & 884 & 0,4 & 1.117 & 0,6 & 1.063 & 0,6 \\
\hline 39 Serviços Prestados às Famílias & 16.805 & 7,4 & 19.320 & 10,2 & 16.980 & 9,2 \\
\hline 40 Serviços Prestados às Empresas & 5.538 & 2,5 & 5.341 & 2,8 & 8.531 & 4,6 \\
\hline 41 Aluguel de Imóveis & 387 & 0,2 & 620 & 0,3 & 683 & 0,4 \\
\hline 42 Administração Pública & 2.498 & 1,1 & 1.374 & 0,7 & 1.195 & 0,6 \\
\hline 43 Serviços Privados não-mercantis & 8.346 & 3,7 & 11.163 & 5,9 & 10.914 & 5,9 \\
\hline Total & 226.053 & 100 & 189.882 & 100 & 184.716 & 100 \\
\hline
\end{tabular}


Tabela 35. Geração de empregos por setor dada uma variação da demanda final de $\mathrm{R} \$ 1$ bilhão da demanda final do setor 35-Supermercados (nova proposta metodológica).

\begin{tabular}{|c|c|c|c|c|c|c|c|c|}
\hline \multirow[b]{2}{*}{ Setor } & \multicolumn{4}{|c|}{$1995 n$} & \multicolumn{4}{|c|}{$1999 n$} \\
\hline & $\begin{array}{l}\text { diretos e } \\
\text { indiretos }\end{array}$ & $\begin{array}{c}\text { Induzi- } \\
\text { dos }\end{array}$ & total & $\%$ & $\begin{array}{l}\text { diretos e I } \\
\text { indiretos }\end{array}$ & $\begin{array}{c}\text { Induzi- } \\
\text { dos }\end{array}$ & total & $\%$ \\
\hline 1 Agropecuária & 46.756 & 18.314 & 65.070 & 44,6 & 36.576 & 17.547 & 54.123 & 35,2 \\
\hline 2 Extrativa Mineral & 104 & - 54 & 158 & 0,1 & 91 & 60 & 152 & 0,1 \\
\hline 3 Petróleo e gás & 17 & 13 & 30 & 0,0 & 43 & 50 & 93 & 0,1 \\
\hline 4 Minerais não-metálicos & 304 & 160 & 465 & 0,3 & 241 & 163 & 404 & 0,3 \\
\hline 5 Siderurgia & 47 & 36 & 83 & 0,1 & 30 & 29 & 59 & 0,0 \\
\hline 6 Metalurgia de não-ferrosos & 30 & 19 & 49 & 0,0 & 29 & 22 & 51 & 0,0 \\
\hline 7 Outros Produtos Metalúrgicos & 678 & 418 & 1.096 & 0,8 & 509 & 390 & 899 & 0,6 \\
\hline 8 Máquinas e Equipamentos & 237 & 160 & 396 & 0,3 & 176 & 166 & 343 & 0,2 \\
\hline 9 Material Elétrico & 275 & 140 & 415 & 0,3 & 140 & 90 & 230 & 0,1 \\
\hline 10 Equipamentos Eletrônicos & 212 & 124 & 336 & 0,2 & 126 & 71 & 198 & 0,1 \\
\hline 11 Automóveis, caminhões e ônibus & 2 & 82 & 84 & 0,1 & 2 & 75 & 77 & 0,0 \\
\hline 12 Peças e outros veículos & 66 & 205 & 270 & 0,2 & 35 & 151 & 186 & 0,1 \\
\hline 13 Madeira e Mobiliário & 258 & 719 & 977 & 0,7 & 195 & 714 & 910 & 0,6 \\
\hline 14 Celulose, Papel e Gráfica & 1.127 & 320 & 1.448 & 1,0 & 1.068 & 407 & 1.474 & 1,0 \\
\hline 15 Indústria da Borracha & 26 & 44 & 70 & 0,0 & 20 & 46 & 65 & 0,0 \\
\hline 16 Elementos Químicos & 65 & 70 & 135 & 0,1 & 66 & 84 & 151 & 0,1 \\
\hline 17 Refino de Petróleo & 61 & 46 & 107 & 0,1 & 53 & 62 & 115 & 0,1 \\
\hline 18 Químicos Diversos & 228 & 99 & 326 & 0,2 & 271 & 150 & 421 & 0,3 \\
\hline 19 Farmacêuticos e Veterinários & 673 & 155 & 828 & 0,6 & 452 & 181 & 634 & 0,4 \\
\hline 20 Artigos Plásticos & 252 & 125 & 377 & 0,3 & 296 & 199 & 495 & 0,3 \\
\hline 21 Indústria Têxtil & 311 & 420 & 730 & 0,5 & 216 & 322 & 538 & 0,4 \\
\hline 22 Artigos do Vestuário & 1.661 & 2.908 & 4.569 & 3,1 & 1.613 & 2.447 & 4.060 & 2,6 \\
\hline 23 Calçados & 170 & 314 & 483 & 0,3 & 226 & 287 & 513 & 0,3 \\
\hline 24 Indústria do Café & 150 & 48 & 198 & 0,1 & 141 & 48 & 189 & 0,1 \\
\hline 25 Beneficiamento de Produtos Vegetais & 1.465 & 376 & 1.840 & 1,3 & 1.493 & 455 & 1.947 & 1,3 \\
\hline 26 Abate de Animais & 750 & 282 & 1.032 & 0,7 & 672 & 342 & 1.014 & 0,7 \\
\hline 27 Indústria de Laticínios & 454 & 83 & 537 & 0,4 & 483 & 91 & 575 & 0,4 \\
\hline 28 Fabricação de Açúcar & 226 & 76 & 302 & 0,2 & 189 & 72 & 261 & 0,2 \\
\hline 29 Fabricação de Óleos Vegetais & 114 & 28 & 142 & 0,1 & 115 & 40 & 155 & 0,1 \\
\hline 30 Outros Produtos Alimentares & 3.000 & 824 & 3.824 & 2,6 & 3.029 & 1.002 & 4.032 & 2,6 \\
\hline 31 Indústrias Diversas & 477 & 277 & 754 & 0,5 & 399 & 263 & 661 & 0,4 \\
\hline $\begin{array}{l}32 \text { Serviços Industriais de Utilidade } \\
\text { Pública }\end{array}$ & 192 & 262 & 453 & 0,3 & 147 & 281 & 428 & 0,3 \\
\hline 33 Construção Civil & 170 & 217 & 387 & 0,3 & 159 & 307 & 466 & 0,3 \\
\hline 34 Comércio & 4.952 & 9.314 & 14.266 & 9,8 & 10.304 & 18.075 & 28.378 & 18,5 \\
\hline 35 Supermercados & 13.067 & 1.023 & 14.091 & 9,7 & 11.599 & 1.154 & 12.753 & 8,3 \\
\hline 36 Transportes & 2.363 & 2.192 & 4.555 & 3,1 & 2.320 & 3.092 & 5.412 & 3,5 \\
\hline 37 Comunicações & 162 & 203 & 365 & 0,3 & 141 & 297 & 438 & 0,3 \\
\hline 38 Instituições Financeiras & 216 & 431 & 647 & 0,4 & 222 & 456 & 678 & 0,4 \\
\hline 39 Serviços Prestados às Famílias & 1.107 & 11.563 & 12.670 & 8,7 & 793 & 13.726 & 14.519 & 9,5 \\
\hline 40 Serviços Prestados às Empresas & 1.580 & 956 & 2.535 & 1,7 & 2.377 & 1.918 & 4.295 & 2,8 \\
\hline 41 Aluguel de Imóveis & 44 & 294 & 338 & 0,2 & 38 & 469 & 507 & 0,3 \\
\hline 42 Administração Pública & 813 & 350 & 1.163 & 0,8 & 637 & 387 & 1.024 & 0,7 \\
\hline 43 Serviços Privados não-mercantis & 0 & 7.337 & 7.337 & 5,0 & 0 & 9.640 & 9.640 & 6,3 \\
\hline Total & 84.859 & 61.081 & 145.940 & 100 & 77.732 & 75.829 & 153.561 & 100 \\
\hline
\end{tabular}




\subsection{Geração de renda}

A análise da capacidade de geração de renda dos setores, e especificamente dos supermercados, pode ser realizada observando-se os valores de renda total gerada (salário líquido) a partir do aumento de um milhão de reais da demanda final (Tabelas 36 e 37) e dos valores dos multiplicadores de renda tipos I e II para cada setor, resumidos nas Tabelas 38 e 39. É importante observar que os valores dos multiplicadores de renda não estão diretamente relacionados à renda total gerada (valores absolutos). Portanto, setores como 29-Fabricação de óleos vegetais possuem multiplicadores de renda tipos I e II relativamente altos, porém, geram valor absoluto de renda comparativamente menor que outros setores da economia.

Os setores que possuíam maior capacidade de geração de renda em termos absolutos (Tabelas 36 e 37) no período analisado eram: 43-Serviços privados não-mercantis, 42Administração pública, 38-Instituições financeiras, 40-Serviços prestados às empresas e 39Serviços prestados às famílias. Deve-se notar também que apesar das médias dos multiplicadores de renda das Tabelas 38 e 39 aumentarem no período 1990/99 e 1995n/99n, os resultados da Tabela 36 de renda média total diminuem no período.

Os valores médios da Tabela 37 para a nova proposta metodológica indicam aumento da renda total gerada na economia, mas isto é resultado do efeito induzido da endogeneização dos preços básicos das mercadorias comercializadas pelos supermercados, estes valores foram alocados como parte de seus custos (consumo intermediário). Este efeito induzido total sobre a economia pode ser compreendido como o impacto da participação do setor 35-Supermercados como equipamento de comercialização dos produtos, gerando um efeito multiplicador de renda.

A capacidade de geração de renda em valores absolutos depende do nível dos salários pagos pelo próprio setor e daqueles diretamente relacionados a ele. $\mathrm{O}$ aumento do valor total dos salários pagos em empregos diretos e indiretos gerados irá desencadear um efeito induzido. No caso do setor 35-Supermercados, o nível dos salários é relativamente baixo, próximo da média do setor 34-Comércio e equivalente à metade da média nacional no ano de 1999 (R \$4,2 mil em salário líquido). 
Tabela 36. Classificação dos setores de acordo com a capacidade de geração de renda para um aumento da demanda de um milhão de reais, valores em $\mathrm{R} \$$ mil (metodologia tradicional).

\begin{tabular}{|c|c|c|c|c|c|c|c|}
\hline \multirow{3}{*}{\multicolumn{2}{|c|}{ Setor }} & \multirow{2}{*}{\multicolumn{2}{|c|}{$\frac{1990}{\text { Renda total }}$}} & \multirow{2}{*}{\multicolumn{2}{|c|}{$\frac{1995}{\text { Renda total }}$}} & \multirow{2}{*}{\multicolumn{2}{|c|}{$\frac{1999}{\text { Renda total }}$}} \\
\hline & & & & & & & \\
\hline & & \multirow{2}{*}{$\frac{\text { ordem }}{41}$} & \multirow{2}{*}{$\frac{\text { valor }}{349,06}$} & \multirow{2}{*}{$\frac{\text { ordem }}{38}$} & \multirow{2}{*}{$\frac{\text { valor }}{323,86}$} & \multirow{2}{*}{$\frac{\text { ordem }}{29}$} & \multirow{2}{*}{$\begin{array}{c}\text { valor } \\
310,31\end{array}$} \\
\hline 1 & Agropecuária & & & & & & \\
\hline 2 & Extrativa Mineral & 17 & 514,38 & 18 & 450,93 & 23 & 354,80 \\
\hline 3 & Petróleo e gás & 40 & 373,17 & 25 & 380,99 & 37 & 281,09 \\
\hline 4 & Minerais não-metálicos & 23 & 461,25 & 23 & 402,92 & 22 & 359,66 \\
\hline 5 & Siderurgia & 30 & 404,64 & 37 & 324,64 & 41 & 264,03 \\
\hline 6 & Metalurgia de não-ferrosos & 39 & 377,46 & 40 & 306,56 & 40 & 271,94 \\
\hline 7 & Outros Produtos Metalúrgicos & 6 & 605,40 & 9 & 496,10 & 14 & 413,35 \\
\hline 8 & Máquinas e Equipamentos & 13 & 548,31 & 19 & 448,11 & 19 & 377,24 \\
\hline 9 & Material Elétrico & 18 & 508,03 & 21 & 415,01 & 25 & 340,22 \\
\hline 10 & Equipamentos Eletrônicos & 33 & 394,59 & 41 & 293,02 & 32 & 302,56 \\
\hline 11 & Automóveis, caminhões e ônibus & 19 & 490,58 & 30 & 349,61 & 33 & 300,20 \\
\hline 12 & Peças e outros veículos & 11 & 554,27 & 16 & 470,29 & 16 & 390,34 \\
\hline 13 & Madeira e Mobiliário & 14 & 539,35 & 15 & 472,48 & 10 & 423,65 \\
\hline 14 & Celulose, Papel e Gráfica & 9 & 569,61 & 10 & 494,31 & 9 & 424,87 \\
\hline 15 & Indústria da Borracha & 37 & 385,04 & 36 & 327,04 & 39 & 275,00 \\
\hline 16 & Elementos Químicos & 34 & 393,55 & 34 & 340,21 & 38 & 280,00 \\
\hline 17 & Refino de Petróleo & 42 & 267,03 & 42 & 244,68 & 42 & 214,55 \\
\hline 18 & Químicos Diversos & 28 & 412,27 & 27 & 369,81 & 30 & 308,38 \\
\hline 19 & Farmacêuticos e Veterinários & 31 & 404,52 & 24 & 388,90 & 26 & 329,95 \\
\hline 20 & Artigos Plásticos & 26 & 418,16 & 29 & 368,96 & 18 & 379,42 \\
\hline 21 & Indústria Têxtil & 38 & 381,52 & 31 & 349,53 & 28 & 315,21 \\
\hline 22 & Artigos do Vestuário & 15 & 516,61 & 13 & 478,81 & 11 & 423,23 \\
\hline 23 & Calçados & 10 & 564,22 & 12 & 483,61 & 13 & 414,04 \\
\hline 24 & Indústria do Café & 32 & 403,97 & 33 & 346,66 & 31 & 305,27 \\
\hline 25 & Beneficiamento de Produtos Vegetais & 29 & 405,05 & 28 & 369,08 & 27 & 320,84 \\
\hline 26 & Abate de Animais & 27 & 413,07 & 26 & 376,17 & 24 & 343,21 \\
\hline 27 & Indústria de Laticínios & 35 & 393,43 & 32 & 347,42 & 34 & 300,10 \\
\hline 28 & Fabricação de Açúcar & 24 & 433,37 & 20 & 427,55 & 20 & 367,53 \\
\hline 29 & Fabricação de Óleos Vegetais & 36 & 387,42 & 35 & 339,36 & 36 & 287,62 \\
\hline 30 & Outros Produtos Alimentares & 22 & 475,12 & 22 & 414,61 & 21 & 363,50 \\
\hline 31 & Indústrias Diversas & 21 & 481,32 & 14 & 478,08 & 17 & 383,57 \\
\hline 32 & Serviços Industriais de Utilidade Pública & 8 & 576,63 & 5 & 547,42 & 15 & 401,67 \\
\hline 33 & Construção Civil & 25 & 427,19 & 39 & 310,14 & 35 & 293,43 \\
\hline 34 & Comércio & 12 & 550,90 & 8 & 515,71 & 7 & 488,26 \\
\hline 35 & Supermercados & 3 & 685,13 & 6 & 541,48 & 6 & 513,43 \\
\hline 36 & Transportes & 16 & 515,42 & 11 & 484,46 & 8 & 455,62 \\
\hline 37 & Comunicações & 5 & 611,43 & 17 & 470,22 & 12 & 417,96 \\
\hline 38 & Instituições Financeiras & 20 & 487,17 & 3 & 663,17 & 3 & 642,43 \\
\hline 39 & Serviços Prestados às Famílias & 4 & 615,05 & 7 & 534,88 & 5 & 563,39 \\
\hline 40 & Serviços Prestados às Empresas & 7 & 588,45 & 4 & 630,62 & 4 & 568,94 \\
\hline 41 & Aluguel de Imóveis & 43 & 164,26 & 43 & 177,98 & 43 & 183,57 \\
\hline 42 & Administração Pública & 2 & 900,93 & 2 & 822,40 & 2 & 783,61 \\
\hline 43 & Serviços Privados não-mercantis & 1 & 1231,62 & 1 & 1193,35 & 1 & 1103,59 \\
\hline Mé & & & 492,56 & & 441,19 & & 428,50 \\
\hline
\end{tabular}


Tabela 37. Classificação dos setores de acordo com a capacidade de geração de renda para um aumento da demanda de um milhão de reais, valores em $\mathrm{R} \$$ mil (nova metodologia).

\begin{tabular}{|c|c|c|c|c|c|}
\hline \multirow{3}{*}{ Setor } & & \multicolumn{2}{|c|}{$1995 n$} & \multicolumn{2}{|c|}{$1999 n$} \\
\hline & & \multicolumn{2}{|c|}{ Renda total } & \multicolumn{2}{|c|}{ Renda total } \\
\hline & & ordem & valor & ordem & valor \\
\hline 1 & Agropecuária & 38 & 302,61 & 29 & 392,23 \\
\hline 2 & Extrativa Mineral & 17 & 443,60 & 23 & 434,97 \\
\hline 3 & Petróleo e gás & 24 & 367,56 & 40 & 348,53 \\
\hline 4 & Minerais não-metálicos & 22 & 390,79 & 22 & 441,06 \\
\hline 5 & Siderurgia & 37 & 311,99 & 41 & 336,34 \\
\hline 6 & Metalurgia de não-ferrosos & 40 & 294,42 & 39 & 349,38 \\
\hline 7 & Outros Produtos Metalúrgicos & 8 & 491,10 & 12 & 499,11 \\
\hline 8 & Máquinas e Equipamentos & 18 & 438,74 & 20 & 457,86 \\
\hline 9 & Material Elétrico & 20 & 406,55 & 24 & 428,19 \\
\hline 10 & Equipamentos Eletrônicos & 41 & 281,90 & 35 & 381,36 \\
\hline 11 & Automóveis, caminhões e ônibus & 30 & 340,10 & 30 & 389,79 \\
\hline 12 & Peças e outros veículos & 15 & 463,78 & 14 & 482,32 \\
\hline 13 & Madeira e Mobiliário & 14 & 465,06 & 9 & 525,53 \\
\hline 14 & Celulose, Papel e Gráfica & 9 & 490,45 & 10 & 524,81 \\
\hline 15 & Indústria da Borracha & 36 & 314,35 & 37 & 357,37 \\
\hline 16 & Elementos Químicos & 35 & 323,65 & 38 & 350,45 \\
\hline 17 & Refino de Petróleo & 42 & 228,74 & 42 & 276,75 \\
\hline 18 & Químicos Diversos & 25 & 361,18 & 32 & 385,13 \\
\hline 19 & Farmacêuticos e Veterinários & 23 & 379,15 & 25 & 421,42 \\
\hline 20 & Artigos Plásticos & 27 & 357,30 & 19 & 459,31 \\
\hline 21 & Indústria Têxtil & 31 & 338,86 & 27 & 405,56 \\
\hline 22 & Artigos do Vestuário & 11 & 480,93 & 8 & 526,12 \\
\hline 23 & Calçados & 12 & 477,87 & 11 & 514,33 \\
\hline 24 & Indústria do Café & 33 & 327,96 & 31 & 389,71 \\
\hline 25 & Beneficiamento de Produtos Vegetais & 28 & 354,87 & 26 & 420,57 \\
\hline 26 & Abate de Animais & 26 & 360,43 & 21 & 443,19 \\
\hline 27 & Indústria de Laticínios & 32 & 330,64 & 34 & 382,53 \\
\hline 28 & Fabricação de Açúcar & 19 & 416,72 & 18 & 462,34 \\
\hline 29 & Fabricação de Óleos Vegetais & 34 & 324,11 & 33 & 383,02 \\
\hline 30 & Outros Produtos Alimentares & 21 & 404,45 & 16 & 468,14 \\
\hline 31 & Indústrias Diversas & 13 & 469,84 & 15 & 470,65 \\
\hline 32 & Serviços Industriais de Utilidade Pública & 5 & 545,00 & 17 & 467,70 \\
\hline 33 & Construção Civil & 39 & 295,42 & 36 & 368,48 \\
\hline 34 & Comércio & 7 & 515,47 & 2 & 1005,56 \\
\hline 35 & Supermercados & 29 & 351,36 & 28 & 399,54 \\
\hline 36 & Transportes & 10 & 484,37 & 7 & 549,69 \\
\hline 37 & Comunicações & 16 & 458,79 & 13 & 487,13 \\
\hline 38 & Instituições Financeiras & 3 & 664,59 & 4 & 726,34 \\
\hline 39 & Serviços Prestados às Famílias & 6 & 536,60 & 5 & 663,88 \\
\hline 40 & Serviços Prestados às Empresas & 4 & 634,44 & 6 & 657,50 \\
\hline 41 & Aluguel de Imóveis & 43 & 146,51 & 43 & 236,17 \\
\hline 42 & Administração Pública & 2 & 838,27 & 3 & 890,75 \\
\hline 43 & Serviços Privados não-mercantis & 1 & 1214,90 & 1 & 1207,31 \\
\hline \multicolumn{2}{|c|}{ Média } & & 428,50 & & 482,58 \\
\hline
\end{tabular}


Os resultados para o multiplicador de renda das Tabelas 38 e 39 são interpretados da seguinte forma: para o ano de 1999, Tabela 38, o multiplicador tipo II do setor 1Agropecuária indica que são gerados $\mathrm{R}$ \$ 4,57 de renda (salário líquido) na economia como um todo para cada um real de renda gerada na própria atividade, considerando-se efeitos diretos, indiretos e induzidos. A interpretação dos valores para o multiplicador tipo I é a mesma, porém, este abrange efeitos diretos e indiretos.

O setor 35-Supermercados possui altos valores dos multiplicadores de renda tipos I e II, quando calculados a partir da matriz de insumo-produto com o setor desagregado pela nova metodologia, porém, o valor total da renda gerada é relativamente baixo. Isto pode ser explicado pelos baixos salários do próprio setor (empregos diretos) e do principal relacionado a este, 1-Agropecuária, no qual é gerada a maior parte dos empregos indiretos, como será detalhado posteriormente.

Os supermercados seguem a tendência da economia de aumento substancial do multiplicador de renda com pequeno aumento, ou diminuição, da renda total gerada. Observando a Tabela 39 nota-se que o multiplicador de renda tipo I do setor 35Supermercados calculado por meio da nova proposta metodológica passa de 6,08 em 1995 para 11,06 em 1999 e o multiplicador tipo II passa de 7,95 para 17,14 (aumento de aproximadamente 116\%) no mesmo período. Estes valores representam um grande efeito induzido causado pelo aumento da demanda final dos supermercados e, conseqüentemente, da renda gerada dentro do próprio setor, calculado como a diferença entre os multiplicadores do tipo I e II: 9,19, valor entre 17,14 (multiplicador tipo II) e 7,95 (multiplicador tipo I). Porém, a renda total gerada para um aumento da produção de um milhão de reais aumenta relativamente menos: de $\mathrm{R} \$ 351,36$ para $\mathrm{R} \$ 399,54$, um crescimento de cerca de $14 \%$, substancialmente menor que o aumento do multiplicador tipo II de $116 \%$ no mesmo período. 
Tabela 38. Multiplicadores de renda* dos setores, valores obtidos de acordo para a metodologia tradicional.

\begin{tabular}{|c|c|c|c|c|c|c|c|}
\hline \multirow{2}{*}{\multicolumn{2}{|c|}{ Setor }} & \multicolumn{2}{|c|}{1990} & \multicolumn{2}{|c|}{1995} & \multicolumn{2}{|c|}{1999} \\
\hline & & \multirow{2}{*}{$\frac{\mathrm{I}}{1,99}$} & \multirow{2}{*}{$\frac{\text { II }}{3,58}$} & \multirow{2}{*}{$\begin{array}{c}\mathrm{I} \\
1,88\end{array}$} & \multirow{2}{*}{$\begin{array}{c}\text { II } \\
4,16\end{array}$} & \multirow{2}{*}{$\frac{\mathrm{I}}{2,02}$} & \multirow{2}{*}{$\begin{array}{c}\text { II } \\
4,57\end{array}$} \\
\hline 1 & Agropecuária & & & & & & \\
\hline 2 & Extrativa Mineral & 2,01 & 3,38 & 2,34 & 4,20 & 2,34 & 4,49 \\
\hline 3 & Petróleo e gás & 2,96 & 5,42 & 2,59 & 5,13 & 2,68 & 6,73 \\
\hline 4 & Minerais não-metálicos & 2,42 & 4,08 & 2,30 & 4,27 & 2,06 & 3,81 \\
\hline 5 & Siderurgia & 5,21 & 8,91 & 6,79 & 13,51 & 8,03 & 17,04 \\
\hline 6 & Metalurgia de não-ferrosos & 4,40 & 7,53 & 4,55 & 8,89 & 5,87 & 11,63 \\
\hline 7 & Outros Produtos Metalúrgicos & 1,81 & 2,89 & 1,75 & 2,95 & 1,75 & 2,99 \\
\hline 8 & Máquinas e Equipamentos & 1,90 & 3,08 & 1,57 & 2,75 & 1,56 & 2,92 \\
\hline 9 & Material Elétrico & 2,30 & 3,75 & 2,47 & 4,35 & 2,63 & 4,63 \\
\hline 10 & Equipamentos Eletrônicos & 2,28 & 3,85 & 2,26 & 4,36 & 2,15 & 4,11 \\
\hline 11 & Automóveis, caminhões e ônibus & 4,14 & 6,93 & 4,21 & 7,72 & 3,51 & 6,40 \\
\hline 12 & Peças e outros veículos & 2,45 & 4,14 & 2,21 & 3,76 & 2,03 & 3,41 \\
\hline 13 & Madeira e Mobiliário & 2,12 & 3,62 & 1,87 & 3,35 & 1,80 & 3,25 \\
\hline 14 & Celulose, Papel e Gráfica & 2,57 & 4,18 & 2,41 & 4,08 & 2,34 & 3,98 \\
\hline 15 & Indústria da Borracha & 2,61 & 4,45 & 2,57 & 4,95 & 2,77 & 5,57 \\
\hline 16 & Elementos Químicos & 2,98 & 5,14 & 2,88 & 5,84 & 3,22 & 7,27 \\
\hline 17 & Refino de Petróleo & 4,36 & 8,18 & 4,26 & 9,96 & 8,00 & 21,82 \\
\hline 18 & Químicos Diversos & 2,07 & 3,45 & 2,14 & 3,83 & 2,30 & 4,41 \\
\hline 19 & Farmacêuticos e Veterinários & 2,41 & 4,13 & 1,91 & 3,46 & 2,24 & 4,40 \\
\hline 20 & Artigos Plásticos & 1,80 & 3,04 & 1,74 & 3,23 & 1,57 & 2,73 \\
\hline 21 & Indústria Têxtil & 3,05 & 5,34 & 2,85 & 5,31 & 3,14 & 5,77 \\
\hline 22 & Artigos do Vestuário & 2,00 & 3,70 & 1,83 & 3,38 & 1,80 & 3,31 \\
\hline 23 & Calçados & 2,18 & 3,50 & 1,94 & 3,26 & 1,85 & 3,20 \\
\hline 24 & Indústria do Café & 3,97 & 6,94 & 3,75 & 7,78 & 4,64 & 10,24 \\
\hline 25 & Beneficiamento de Produtos Vegetais & 3,33 & 5,75 & 3,37 & 6,56 & 3,56 & 7,27 \\
\hline 26 & Abate de Animais & 4,20 & 7,25 & 3,64 & 7,13 & 4,29 & 8,57 \\
\hline 27 & Indústria de Laticínios & 5,00 & 8,71 & 4,49 & 9,08 & 3,87 & 7,87 \\
\hline 28 & Fabricação de Açúcar & 3,44 & 5,86 & 3,03 & 5,45 & 2,97 & 5,43 \\
\hline 29 & Fabricação de Óleos Vegetais & 7,97 & 14,06 & 8,40 & 16,96 & 9,84 & 21,41 \\
\hline 30 & Outros Produtos Alimentares & 2,75 & 4,59 & 2,65 & 4,81 & 2,62 & 4,90 \\
\hline 31 & Indústrias Diversas & 2,04 & 3,46 & 1,96 & 3,46 & 2,29 & 4,14 \\
\hline 32 & Serviços Industriais de Utilidade Pública & 1,64 & 2,61 & 1,52 & 2,48 & 1,66 & 3,04 \\
\hline 33 & Construção Civil & 2,07 & 3,63 & 2,20 & 4,80 & 2,31 & 5,32 \\
\hline 34 & Comércio & 1,37 & 2,47 & 1,37 & 2,53 & 1,44 & 2,60 \\
\hline 35 & Supermercados & 1,37 & 2,29 & 1,51 & 2,72 & 1,63 & 2,76 \\
\hline 36 & Transportes & 1,52 & 2,68 & 1,45 & 2,54 & 1,62 & 2,86 \\
\hline 37 & Comunicações & 1,17 & 1,89 & 1,19 & 2,11 & 1,21 & 2,24 \\
\hline 38 & Instituições Financeiras & 1,16 & 1,95 & 1,26 & 2,02 & 1,30 & 2,04 \\
\hline 39 & Serviços Prestados às Famílias & 1,45 & 2,57 & 1,36 & 2,41 & 1,31 & 2,21 \\
\hline 40 & Serviços Prestados às Empresas & 1,36 & 2,37 & 1,25 & 2,07 & 1,28 & 2,15 \\
\hline 41 & Aluguel de Imóveis & 1,81 & 5,46 & 1,56 & 11,05 & 1,44 & 12,82 \\
\hline 42 & Administração Pública & 1,17 & 1,93 & 1,21 & 1,92 & 1,16 & 1,82 \\
\hline 43 & Serviços Privados não-mercantis & 1,02 & 1,48 & 1,02 & 1,42 & 1,02 & 1,42 \\
\hline Mé & dia & 2,60 & 4,52 & 2,55 & 5,02 & 2,77 & 5,80 \\
\hline
\end{tabular}

* salário líquido 
Tabela 39. Multiplicadores de renda* dos setores, valores obtidos de acordo com a nova proposta metodológica.

\begin{tabular}{|c|c|c|c|c|c|}
\hline \multirow{2}{*}{\multicolumn{2}{|c|}{ Setor }} & \multicolumn{2}{|c|}{$1995 n$} & \multicolumn{2}{|c|}{$1999 n$} \\
\hline & & \multirow{2}{*}{$\frac{I}{1,88}$} & \multirow{2}{*}{$\begin{array}{c}\text { II } \\
3,89\end{array}$} & \multirow{2}{*}{$\frac{\mathrm{I}}{2,21}$} & \multirow{2}{*}{$\begin{array}{c}\mathrm{II} \\
5,77\end{array}$} \\
\hline 1 & Agropecuária & & & & \\
\hline 2 & Extrativa Mineral & 2,34 & 4,14 & 2,50 & 5,50 \\
\hline 3 & Petróleo e gás & 2,59 & 4,95 & 2,84 & 8,35 \\
\hline 4 & Minerais não-metálicos & 2,30 & 4,14 & 2,20 & 4,67 \\
\hline 5 & Siderurgia & 6,79 & 12,99 & 8,91 & 21,70 \\
\hline 6 & Metalurgia de não-ferrosos & 4,55 & 8,54 & 6,60 & 14,94 \\
\hline 7 & Outros Produtos Metalúrgicos & 1,75 & 2,92 & 1,86 & 3,61 \\
\hline 8 & Máquinas e Equipamentos & 1,57 & 2,69 & 1,66 & 3,54 \\
\hline 9 & Material Elétrico & 2,47 & 4,26 & 2,90 & 5,82 \\
\hline 10 & Equipamentos Eletrônicos & 2,26 & 4,19 & 2,36 & 5,19 \\
\hline 11 & Automóveis, caminhões e ônibus & 4,21 & 7,51 & 3,99 & 8,31 \\
\hline 12 & Peças e outros veículos & 2,21 & 3,71 & 2,20 & 4,21 \\
\hline 13 & Madeira e Mobiliário & 1,87 & 3,30 & 1,96 & 4,03 \\
\hline 14 & Celulose, Papel e Gráfica & 2,41 & 4,05 & 2,54 & 4,92 \\
\hline 15 & Indústria da Borracha & 2,57 & 4,76 & 3,15 & 7,24 \\
\hline 16 & Elementos Químicos & 2,88 & 5,55 & 3,49 & 9,10 \\
\hline 17 & Refino de Petróleo & 4,26 & 9,31 & 8,94 & 28,15 \\
\hline 18 & Químicos Diversos & 2,14 & 3,74 & 2,51 & 5,51 \\
\hline 19 & Farmacêuticos e Veterinários & 1,91 & 3,37 & 2,50 & 5,62 \\
\hline 20 & Artigos Plásticos & 1,74 & 3,13 & 1,67 & 3,31 \\
\hline 21 & Indústria Têxtil & 2,85 & 5,14 & 3,53 & 7,42 \\
\hline 22 & Artigos do Vestuário & 1,83 & 3,39 & 1,96 & 4,12 \\
\hline 23 & Calçados & 1,94 & 3,22 & 2,02 & 3,97 \\
\hline 24 & Indústria do Café & 3,75 & 7,36 & 5,16 & 13,08 \\
\hline 25 & Beneficiamento de Produtos Vegetais & 3,37 & 6,30 & 4,09 & 9,53 \\
\hline 26 & Abate de Animais & 3,64 & 6,83 & 4,85 & 11,07 \\
\hline 27 & Indústria de Laticínios & 4,49 & 8,64 & 4,31 & 10,03 \\
\hline 28 & Fabricação de Açúcar & 3,03 & 5,31 & 3,27 & 6,83 \\
\hline 29 & Fabricação de Óleos Vegetais & 8,40 & 16,19 & 11,50 & 28,52 \\
\hline 30 & Outros Produtos Alimentares & 2,65 & 4,69 & 2,96 & 6,31 \\
\hline 31 & Indústrias Diversas & 1,96 & 3,40 & 2,46 & 5,08 \\
\hline 32 & Serviços Industriais de Utilidade Pública & 1,52 & 2,47 & 1,69 & 3,54 \\
\hline 33 & Construção Civil & 2,20 & 4,57 & 2,51 & 6,68 \\
\hline 34 & Comércio & 1,37 & 2,53 & 1,48 & 3,05 \\
\hline 35 & Supermercados & 6,08 & 11,06 & 7,95 & 17,14 \\
\hline 36 & Transportes & 1,45 & 2,54 & 1,72 & 3,45 \\
\hline 37 & Comunicações & 1,19 & 2,06 & 1,24 & 2,61 \\
\hline 38 & Instituições Financeiras & 1,26 & 2,03 & 1,31 & 2,31 \\
\hline 39 & Serviços Prestados às Famílias & 1,36 & 2,42 & 1,36 & 2,60 \\
\hline 40 & Serviços Prestados às Empresas & 1,25 & 2,08 & 1,31 & 2,48 \\
\hline 41 & Aluguel de Imóveis & 1,56 & 9,10 & 1,47 & 16,49 \\
\hline & Administração Pública & 1,21 & 1,96 & 1,18 & 2,07 \\
\hline 43 & Serviços Privados não-mercantis & 1,02 & 1,45 & 1,02 & 1,55 \\
\hline Mé & dia & 2,65 & 5,02 & 3,19 & 7,66 \\
\hline
\end{tabular}

* salário líquido 
As Tabelas 40 e 41 trazem detalhamentos sobre a geração de renda em valores absolutos para cada setor da economia. Estes números foram calculados, respectivamente, com base nas matrizes de insumo-produto de 1990/95/99 com o setor 35-Supermercados desagregado pela metodologia tradicional e pela nova proposta metodológica para os anos 1995n/99n. Observando os valores da Tabela 40, nota-se que as médias da capacidade de geração de renda dos setores, por efeito direto, indireto e induzido diminuem sensivelmente. O setor supermercadista acompanhou esta tendência, reduzindo sua capacidade de geração de renda total de aproximadamente $25 \%$ no período 1990/99, resultados da metodologia tradicional. Os resultados para a nova proposta metodológica, resumidos na Tabela 41, seguem a mesma tendência das médias da Tabela 40, com exceção da renda gerada por efeito induzido que aumentou consideravelmente entre os anos de 1995n e 1999n.

A partir da metodologia tradicional, os valores obtidos da variação de um milhão de reais do valor de produção do setor 35-Supermercados para o ano de 1999 (Tabela 40) indicam que cerca de $\mathrm{R} \$ 186$ mil do total de $\mathrm{R} \$ 513,43$ mil da renda total consistiriam de salários adicionais pagos aos funcionários dos supermercados, enquanto o restante da renda seriam salários gerados em outros setores indiretamente e por efeito induzido. Os resultados da nova proposta metodológica para 1999 são de que aproximadamente R \$ 23 mil da renda total de $\mathrm{R} \$ 400$ mil gerada pelo aumento da demanda dos 35-Supermercados seriam gerados na própria atividade.

A Tabela 41 possui os resultados obtidos pela aplicação da nova metodologia. Observa-se que os valores para a geração de renda direta e indireta dos setores se aproximam dos números da Tabela 40, porém, os valores de renda gerada por efeito induzido são maiores que para a metodologia tradicional, considerando-se o efeito adicional da incorporação de valores a preços básicos dos produtos adquiridos pelos supermercados para seu consumo intermediário.

No caso dos supermercados, a diminuição da renda direta gerada é efeito da automação comercial acompanhada de uma diminuição do nível de salários, como foi detalhado na Revisão de literatura. Além destes fatores, é importante considerar o impacto do aumento do tamanho das lojas, principalmente no período 1990/95, na diminuição da geração 
de emprego e renda, pois a conversão de pequenos estabelecimentos em supermercados compactos trouxe um ganho real de escala para as pequenas empresas, sem considerar o efeito do aumento do tamanho das lojas das grandes redes do varejo.

Deve-se levar em conta que a geração de renda indireta do setor supermercadista se manteve em valores relativamente próximos ao longo do período 1990/99 considerando as duas séries de resultados das metodologias utilizadas, enquanto o efeito induzido se tornou mais importante no período 1995n/99n quando analisados os valores da nova proposta metodológica. O efeito induzido fez com que o valor total da renda gerada em 1999n fosse maior que em 1995n. Portanto, o impacto do aumento da demanda dos 35-Supermercados sobre a renda de outros setores é principalmente por efeito induzido, havendo pouca variação da capacidade de geração de renda por efeito indireto, sendo que a própria atividade contribui com pequena parcela da renda total gerada.

A vantagem da nova proposta metodológica para a análise do setor 35Supermercados é a estimativa do efeito induzido da variação de sua demanda final. Conforme anteriormente analisado, apesar da diminuição da capacidade de geração de renda direta dos supermercados, o crescimento do efeito induzido fez aumentar o valor total da renda gerada na economia. Portanto, os resultados da nova metodologia proposta se aproximam da realidade, pois a forte relação com outros setores da economia gera um efeito induzido muito maior que o captado nos resultados da metodologia tradicional.

A Figura 9 foi elaborada com os resultados para o ano de 1999 da Tabela 41 e permite visualizar a participação de cada tipo de renda gerada (direta, indireta e induzida) no total. Nota-se que os setores de serviços apresentam a característica de gerar principalmente renda direta, em menor porcentagem renda induzida e em menor escala renda indireta. Por outro lado, a indústria gera principalmente renda induzida, em menor participação renda indireta e em porcentagens menores a renda direta. O setor 35-Supermercados desagregado pela nova proposta metodológica apresenta características de uma indústria, gerando renda em proporções muito próximas às do setor 5-Siderurgia. Observa-se a maior participação da renda gerada por efeito induzido e pequena parcela de renda direta, derivada na própria atividade. 
Tabela 40. Geração de renda direta (dir), indireta (indir) e induzida (indu) dos setores para uma variação da demanda final de um milhão de reais, valores em $\mathrm{R} \$$ mil (metodologia tradicional).

\begin{tabular}{|c|c|c|c|c|c|c|c|c|c|}
\hline \multirow{2}{*}{ Setor } & \multicolumn{3}{|c|}{1990} & \multicolumn{3}{|c|}{1995} & \multicolumn{3}{|c|}{1999} \\
\hline & $\operatorname{dir}$ & indir & indu & $\operatorname{dir}$ & indir & indu & dir & indir & indu \\
\hline Agropecuária & 97,6 & 96,1 & 155,3 & 77,8 & 68,9 & 177,2 & 67,9 & 69,2 & 173,1 \\
\hline 2 Extrativa Mineral & 152,1 & 153,9 & 208,4 & 107,3 & 143,6 & 200,0 & 79,1 & 106,0 & 169,7 \\
\hline 3 Petróleo e gás & 68,9 & 135,3 & 169,0 & 74,2 & 117,7 & 189,0 & 41,7 & 70,2 & 169,1 \\
\hline 4 Minerais não-metálicos & 113,0 & 160,1 & 188,2 & 94,4 & 122,6 & 185,9 & 94,4 & 99,7 & 165,5 \\
\hline 5 Siderurgia & 45,4 & 191,4 & 167,8 & 24,0 & 139,1 & 161,5 & 15,5 & 109,0 & 139,6 \\
\hline 6 Metalurgia de não-ferrosos & 50,1 & 170,2 & 157,1 & 34,5 & 122,3 & 149,8 & 23,4 & 114,0 & 134,6 \\
\hline 7 Outros Produtos Metalúrgicos & 209,8 & 170,5 & 225,0 & 167,9 & 125,7 & 202,5 & 138,3 & 103,3 & 171,7 \\
\hline 8 Máquinas e Equipamentos & 177,9 & 161,0 & 209,4 & 163,0 & 93,7 & 191,4 & 129,3 & 73,0 & 174,9 \\
\hline Material Elétrico & 135,6 & 175,7 & 196,8 & 95,3 & 139,9 & 179,8 & 73,6 & 119,6 & 147,1 \\
\hline 10 Equipamentos Eletrônicos & 102,4 & 131,4 & 160,8 & 67,2 & 84,6 & 141,2 & 73,5 & 84,4 & 144,7 \\
\hline 11 Automóveis, caminhões e ônibus & 70,7 & 221,8 & 198,0 & 45,3 & 145,3 & 159,0 & 46,9 & 117,5 & 135,8 \\
\hline 12 Peças e outros ve & 133,9 & 193,8 & 226,6 & 125,1 & 151,8 & 193,4 & 114,4 & 117,5 & 158,4 \\
\hline 13 Made & 148,9 & 166,6 & 223,9 & 141,0 & 122,5 & 208,9 & 130,3 & 104,4 & 188,9 \\
\hline 14 Celul & 136,2 & 213,8 & 219,6 & 121,0 & 170,1 & 203,2 & 106,7 & 142,8 & 175,4 \\
\hline 15 Indú: & 86,5 & 139,4 & 159,1 & 66,0 & 103,5 & 157,5 & 49,3 & 87,4 & 138,3 \\
\hline 16 Elem & 76,6 & 151,8 & 165,1 & 58,3 & 109,6 & 172,4 & 38,5 & 85,6 & 155,8 \\
\hline 17 Refir & 32,7 & 109,7 & 124,6 & 24,6 & 80,0 & 140,1 & 9,8 & 68,8 & 135,9 \\
\hline 18 Quír & 19,5 & 127,6 & 165 & 96,6 & 110,4 & 162,8 & 69,9 & 91,1 & 147,5 \\
\hline 19 Farn & 98,0 & 138,3 & 168,2 & 112,4 & 101,9 & 174,5 & 75,0 & 93,0 & 161,9 \\
\hline 20 Arti & 137,5 & 110,2 & 170,5 & 114,1 & 84,5 & 170,4 & 138,8 & 78,7 & 161,9 \\
\hline 21 Indú & 71,5 & 146,8 & 163,2 & 65,9 & 122,1 & 161,6 & 54,7 & 116,8 & 143,8 \\
\hline 22 Artig & 139,7 & 140,0 & 237,0 & 141,9 & 117,2 & 219,8 & 127,7 & 102,6 & 193,0 \\
\hline 23 Calçados & 161,2 & 189,7 & 213,3 & 148,3 & 139,5 & 195,8 & 129,6 & 110,1 & 174,3 \\
\hline 24 Indústria & 58,2 & 172,8 & 173,0 & 44,5 & 122,4 & 179,7 & 29,8 & 108,6 & 166,9 \\
\hline 25 Beneficiamento de & 70,5 & 163,9 & 170,6 & 56,3 & 133,6 & 179,2 & 44,2 & 113,0 & 163,7 \\
\hline 26 Abate de Animais & 56,9 & 181,9 & 174,2 & 52,8 & 139,2 & 184,2 & 40,0 & 131,9 & 171,3 \\
\hline 27 Indústria de Lat & 45,2 & 180,5 & 167,8 & 38,3 & 133,5 & 175,6 & 38,1 & 109,6 & 152,4 \\
\hline 28 Fabrica & 73,9 & 180,5 & 178,9 & 78,5 & 159,2 & 189,9 & 67,7 & 133,6 & 166,2 \\
\hline 29 Fabricação de Óleos & 27,5 & 192,1 & 167,8 & 20,0 & 148,1 & 171,2 & 13,4 & 118,7 & 155,5 \\
\hline 30 Outros Produtos Alimentares & 103,5 & 181,2 & 190,4 & 86,3 & 142,6 & 185,8 & 74,2 & 120,6 & 168,7 \\
\hline 31 Indústrias Diversas & 139,0 & 144,4 & 197,9 & 138,1 & 132,6 & 207,3 & 92,6 & 119,6 & 171,3 \\
\hline 32 Serviços Industriais de Utilidade Pública & 221,2 & 141,7 & 213,7 & 220,8 & 114,5 & 212,2 & 132,0 & 86,6 & 183,0 \\
\hline 33 Construção Civil & 117,6 & 125,7 & 183,9 & 64,6 & 77,3 & 168,2 & 55,2 & 72,4 & 165,9 \\
\hline 34 Comércio & 223,3 & 83,2 & 244,5 & 203,9 & 75,7 & 236,2 & 187,8 & 82,4 & 218,1 \\
\hline 35 Supermercados & 299,4 & 109,7 & 276,0 & 198,9 & 102,0 & 240,6 & 185,8 & 117,2 & 210,4 \\
\hline 36 Transportes & 192,5 & 99,2 & 223,7 & 190,7 & 85,4 & 208,4 & 159,5 & 98,9 & 197,2 \\
\hline 37 Comunicações & 323,0 & 55,6 & 232,8 & 222,8 & 41,9 & 205,5 & 186,5 & 39,9 & 191,6 \\
\hline 38 Instituições Financeiras & 250,4 & 39,6 & 197,1 & 327,8 & 84,1 & 251,3 & 314,7 & 93,3 & 234,4 \\
\hline 39 Serviços Prestados às Famílias & 239,5 & 108,2 & 267,3 & 221,8 & 79,7 & 233,4 & 255,4 & 78,5 & 229,5 \\
\hline 40 Serviços Prestados às Empresas & 248,0 & 88,2 & 252,3 & 304,8 & 76,1 & 249,7 & 264,9 & 73,9 & 230,1 \\
\hline 41 Aluguel de Imóveis & 30,1 & 24,2 & 110,0 & 16,1 & 9,1 & 152,8 & 14,3 & 6,3 & 163,0 \\
\hline 42 Administração Pública & 466,8 & 78,9 & 355,3 & 428,6 & 90,9 & 302,9 & 431,2 & 70,3 & 282,1 \\
\hline 43 Serviços Privados não-mercantis & 832,9 & 20,7 & 378,1 & 839,0 & 14,7 & 339,6 & 776,6 & 12,6 & 314,4 \\
\hline Média & 153,1 & 138,8 & 200,6 & 137,7 & 108,8 & 194,7 & 120,8 & 94,2 & 176,7 \\
\hline
\end{tabular}


Tabela 41. Geração de renda direta (dir), indireta (indir) e induzida (indu) dos setores para uma variação da demanda final de um milhão de reais, valores em $\mathrm{R} \$$ mil (nova proposta metodológica).

\begin{tabular}{|c|c|c|c|c|c|c|}
\hline \multirow{2}{*}{ Setor } & \multicolumn{3}{|c|}{$1995 n$} & \multicolumn{3}{|c|}{$1999 n$} \\
\hline & dir & indir & indu & $\operatorname{dir}$ & indir & indu \\
\hline Agropecuária & 77,83 & 68,85 & 155,93 & 67,94 & 82,36 & 241,94 \\
\hline Extrativa Mineral & 107,26 & 143,62 & 192,72 & 79,07 & 118,81 & 237,09 \\
\hline Petróleo e gás & 74,22 & 117,73 & 175,61 & 41,75 & 76,93 & 229,86 \\
\hline Minerais não-metálicos & 94,44 & 122,57 & 173,78 & 94,43 & 113,75 & 232,89 \\
\hline Siderurgia & 24,02 & 139,08 & 148,89 & 15,50 & 122,60 & 198,24 \\
\hline Metalurgia de não-ferrosos & 34,49 & 122,31 & 137,62 & 23,39 & 130,86 & 195,13 \\
\hline Outros Produtos Metalúrgicos & 167,93 & 125,66 & 197,51 & 138,30 & 118,54 & 242,27 \\
\hline Máquinas e Equipamentos & 163,02 & 93,66 & 182,06 & 129,30 & 85,25 & 243,31 \\
\hline Material Elétrico & 95,33 & 139,86 & 171,35 & 73,55 & 139,68 & 214,95 \\
\hline 10 Equipamentos Eletrônicos & 67,22 & 84,60 & 130,08 & 73,53 & 100,36 & 207,46 \\
\hline 11 Automóveis, caminhões e ônibus & 45,30 & 145,31 & 149,48 & 46,89 & 140,07 & 202,84 \\
\hline 12 Peças e outros veículos & 125,08 & 151,84 & 186,86 & 114,44 & 137,78 & 230,10 \\
\hline 13 Madeira e Mobiliário & 141,04 & 122,53 & 201,48 & 130,31 & 124,78 & 270,44 \\
\hline 14 Celulose, Papel e Gráfica & 121,03 & 170,12 & 199,30 & 106,66 & 164,32 & 253,83 \\
\hline 15 Indústria da Borracha & 66,03 & 103,48 & 144,84 & 49,33 & 106,07 & 201,97 \\
\hline 16 Elementos Químicos & 58,28 & 109,56 & 155,80 & 38,52 & 95,86 & 216,07 \\
\hline 17 Refino de Petróleo & 24,58 & 80,05 & 124,11 & 9,83 & 78,08 & 188,83 \\
\hline 18 Químicos Diversos & 96,59 & 110,44 & 154,15 & 69,86 & 105,63 & 209,64 \\
\hline 19 Farmacêuticos e Veterinários & 112,43 & 101,93 & 164,80 & 75,03 & 112,44 & 233,94 \\
\hline 20 Artigos Plásticos & 114,08 & 84,52 & 158,69 & 138,83 & 92,55 & 227,93 \\
\hline 21 Indústria Têxtil & 65,87 & 122,05 & 150,94 & 54,65 & 138,49 & 212,41 \\
\hline 22 Artigos do Vestuário & 141,85 & 117,16 & 221,91 & 127,68 & 122,81 & 275,63 \\
\hline 23 Calçados & 148,26 & 139,54 & 190,06 & 129,59 & 131,98 & 252,76 \\
\hline 24 Indústria do Café & 44,54 & 122,41 & 161,02 & 29,81 & 123,93 & 235,98 \\
\hline 25 Beneficiamento de Produtos Vegetais & 56,30 & 133,56 & 165,01 & 44,15 & 136,23 & 240,20 \\
\hline 26 Abate de Animais & 52,78 & 139,19 & 168,46 & 40,03 & 154,08 & 249,08 \\
\hline 27 Indústria de Laticínios & 38,28 & 133,53 & 158,83 & 38,13 & 126,13 & 218,27 \\
\hline 28 Fabricação de Açúcar & 78,49 & 159,20 & 179,02 & 67,73 & 154,03 & 240,57 \\
\hline 29 Fabricação de Óleos Vegetais & 20,01 & 148,12 & 155,98 & 13,43 & 141,09 & 228,50 \\
\hline 30 Outros Produtos Alimentares & 86,26 & 142,57 & 175,62 & 74,20 & 145,39 & 248,54 \\
\hline 31 Indústrias Diversas & 138,14 & 132,62 & 199,08 & 92,62 & 135,56 & 242,46 \\
\hline 32 Serviços Industriais de Utilidade Pública & 220,77 & 114,47 & 209,75 & 132,04 & 90,51 & 245,14 \\
\hline 33 Construção Civil & 64,63 & 77,34 & 153,45 & 55,19 & 83,28 & 230,00 \\
\hline 34 Comércio & 203,91 & 75,65 & 235,92 & 329,27 & 158,10 & 518,19 \\
\hline 35 Supermercados & 31,78 & 161,42 & 158,15 & 23,31 & 161,91 & 214,32 \\
\hline 36 Transportes & 190,69 & 85,41 & 208,28 & 159,52 & 114,21 & 275,97 \\
\hline 37 Comunicações & 222,81 & 41,89 & 194,09 & 186,47 & 43,97 & 256,69 \\
\hline 38 Instituições Financeiras & 327,76 & 84,08 & 252,75 & 314,70 & 98,00 & 313,63 \\
\hline 39 Serviços Prestados às Famílias & 221,80 & 79,50 & 235,30 & 255,38 & 91,84 & 316,66 \\
\hline 40 Serviços Prestados às Empresas & 304,77 & 76,12 & 253,54 & 264,95 & 81,48 & 311,07 \\
\hline 41 Aluguel de Imóveis & 16,10 & 9,09 & 121,32 & 14,32 & 6,76 & 215,08 \\
\hline 42 Administração Pública & 428,60 & 90,90 & 318,77 & 431,21 & 78,92 & 380,61 \\
\hline 43 Serviços Privados não-mercantis & 839,03 & 14,75 & 361,12 & 776,59 & 14,59 & 416,13 \\
\hline Média & 133,81 & 110,19 & 184,50 & 120,27 & 111,16 & 251,55 \\
\hline
\end{tabular}



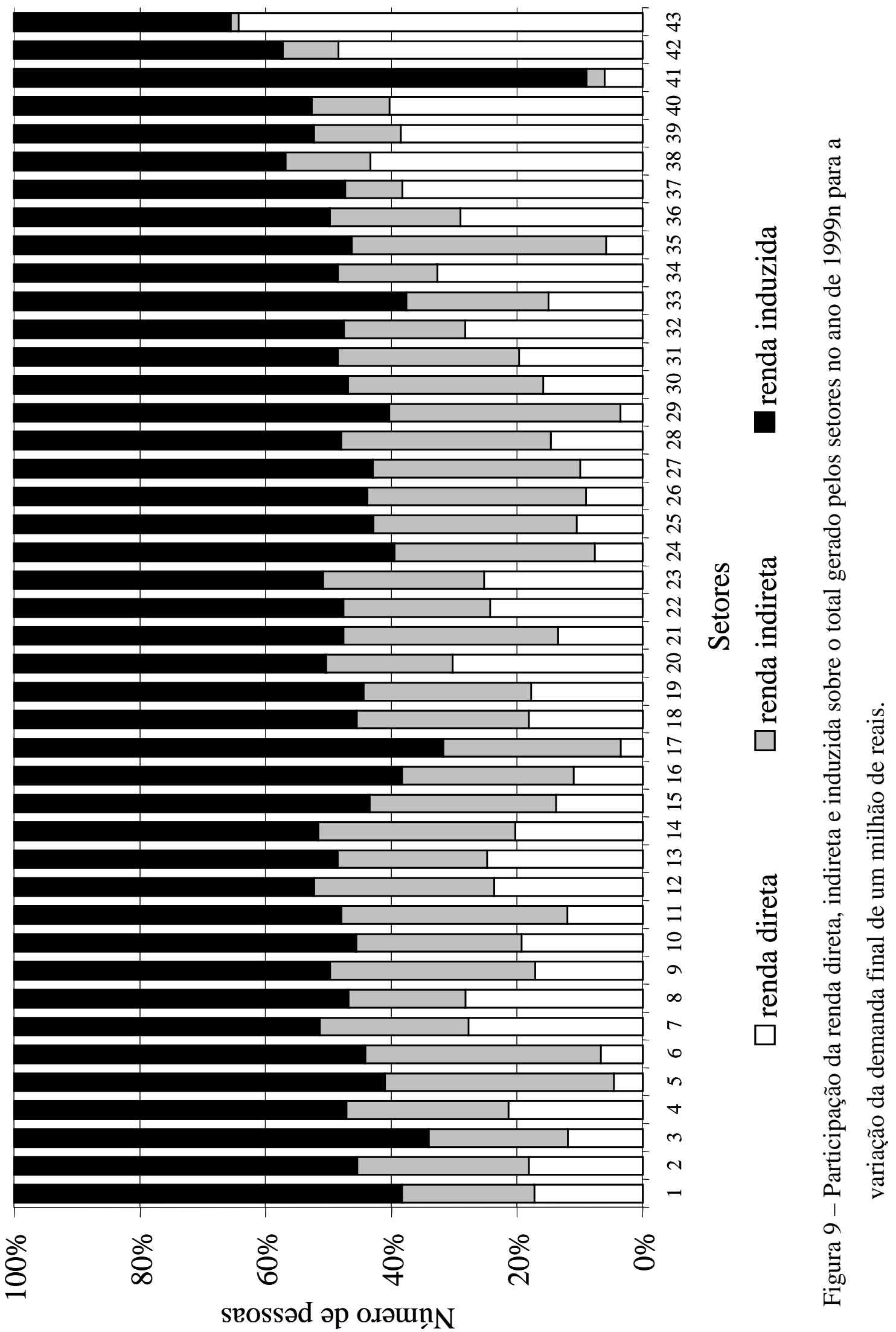
Os resultados do impacto de um aumento da demanda final do setor supermercadista em um milhão de reais sobre a renda gerada em cada setor da economia, em valores absolutos, estão resumidos nas Tabelas 42 (metodologia tradicional) e 43 (nova proposta metodológica). Observa-se que os resultados da metodologia tradicional indicam uma diminuição da renda total gerada, mas sem levar em consideração o efeito induzido do aumento de vendas das mercadorias comercializadas pelos supermercados. A análise dos valores calculados utilizando-se a nova proposta metodológica permite notar que a renda direta do setor 35-Supermercados e indireta dos setores diretamente relacionados a ele diminuiu no período, porém, a renda gerada por efeito induzido aumentou de cerca de R\$158 mil para R\$214 mil entre 1995 e 1999.

Os valores da Tabela 43 evidenciam que os maiores montantes de renda são gerados nos setores 34-Comércio, 39-Serviços prestados às famílias, 1-Agropecuária, 35-Supermercados, 38-Instituições financeiras e 40-Serviços prestados às empresas. A maior parte da renda dos setores de serviços é gerada por efeito induzido, enquanto a renda gerada na agricultura e indústria provém de efeito indireto. No caso do setor 34Comércio, a maior parte da renda é gerada por efeito induzido e, na 1-Agricultura, aproximadamente um terço é gerado por efeito induzido e dois terços por efeito indireto.

A nova proposta metodológica permite analisar o efeito induzido das vendas dos supermercados sobre a economia. Os resultados da geração de renda da Tabela 43 mostram que existe um aumento do efeito induzido sobre a renda dos setores, notadamente comércio e serviços. Apesar da diminuição da capacidade de geração de renda na própria atividade e em setores diretamente relacionados, o efeito induzido apresentou aumento suficiente para que a renda total gerada por milhão de reais de produção crescesse em mais de 10\% entre 1995 e 1999. 
Tabela 42. Geração de renda por setor dada uma variação da demanda final de R \$ 1 milhão do setor 35-Supermercados, valores em R \$ mil (metodologia tradicional).

\begin{tabular}{|c|c|c|c|c|c|c|}
\hline \multirow{2}{*}{ Setor } & \multicolumn{2}{|c|}{1990} & \multicolumn{2}{|c|}{1995} & \multicolumn{2}{|c|}{1999} \\
\hline & valor & $\%$ & valor & $\%$ & valor & $\%$ \\
\hline 1 Agropecuária & 17,81 & 2,6 & 15,10 & 2,8 & 12,06 & 2,3 \\
\hline 2 Extrativa Mineral & 1,00 & 0,1 & 0,51 & 0,1 & 0,32 & 0,1 \\
\hline 3 Petróleo e gás & 1,39 & 0,2 & 0,66 & 0,1 & 0,84 & 0,2 \\
\hline 4 Minerais não-metálicos & 1,90 & 0,3 & 1,32 & 0,2 & 1,15 & 0,2 \\
\hline 5 Siderurgia & 1,36 & 0,2 & 0,59 & 0,1 & 0,33 & 0,1 \\
\hline 6 Metalurgia de não-ferrosos & 0,74 & 0,1 & 0,35 & 0,1 & 0,22 & 0,0 \\
\hline 7 Outros Produtos Metalúrgicos & 6,98 & 1,0 & 5,06 & 0,9 & 3,56 & 0,7 \\
\hline 8 Máquinas e Equipamentos & 6,77 & 1,0 & 5,24 & 1,0 & 3,39 & 0,7 \\
\hline 9 Material Elétrico & 3,08 & 0,4 & 1,93 & 0,4 & 1,19 & 0,2 \\
\hline 10 Equipamentos Eletrônicos & 2,65 & 0,4 & 1,66 & 0,3 & 0,85 & 0,2 \\
\hline 11 Automóveis, caminhões e ônibus & 1,75 & 0,3 & 1,36 & 0,3 & 1,17 & 0,2 \\
\hline 12 Peças e outros veículos & 4,25 & 0,6 & 3,43 & 0,6 & 2,31 & 0,4 \\
\hline 13 Madeira e Mobiliário & 4,04 & 0,6 & 3,12 & 0,6 & 2,55 & 0,5 \\
\hline 14 Celulose, Papel e Gráfica & 15,82 & 2,3 & 9,69 & 1,8 & 8,72 & 1,7 \\
\hline 15 Indústria da Borracha & 1,31 & 0,2 & 0,78 & 0,1 & 0,53 & 0,1 \\
\hline 16 Elementos Químicos & 2,55 & 0,4 & 1,52 & 0,3 & 0,99 & 0,2 \\
\hline 17 Refino de Petróleo & 3,98 & 0,6 & 2,03 & 0,4 & 1,10 & 0,2 \\
\hline 18 Químicos Diversos & 5,16 & 0,8 & 2,95 & 0,5 & 2,27 & 0,4 \\
\hline 19 Farmacêuticos e Veterinários & 2,87 & 0,4 & 3,20 & 0,6 & 2,37 & 0,5 \\
\hline 20 Artigos Plásticos & 5,09 & 0,7 & 2,74 & 0,5 & 3,12 & 0,6 \\
\hline 21 Indústria Têxtil & 5,16 & 0,8 & 2,88 & 0,5 & 1,98 & 0,4 \\
\hline 22 Artigos do Vestuário & 6,14 & 0,9 & 3,79 & 0,7 & 2,57 & 0,5 \\
\hline 23 Calçados & 2,91 & 0,4 & 1,37 & 0,3 & 0,86 & 0,2 \\
\hline 24 Indústria do Café & 0,39 & 0,1 & 0,43 & 0,1 & 0,25 & 0,0 \\
\hline 25 Beneficiamento de Produtos Vegetais & 3,00 & 0,4 & 2,54 & 0,5 & 1,92 & 0,4 \\
\hline 26 Abate de Animais & 2,65 & 0,4 & 2,28 & 0,4 & 1,79 & 0,3 \\
\hline 27 Indústria de Laticínios & 1,04 & 0,2 & 0,81 & 0,2 & 0,65 & 0,1 \\
\hline 28 Fabricação de Açúcar & 0,99 & 0,1 & 0,73 & 0,1 & 0,60 & 0,1 \\
\hline 29 Fabricação de Óleos Vegetais & 0,52 & 0,1 & 0,43 & 0,1 & 0,31 & 0,1 \\
\hline 30 Outros Produtos Alimentares & 6,44 & 0,9 & 5,67 & 1,0 & 4,63 & 0,9 \\
\hline 31 Indústrias Diversas & 2,58 & 0,4 & 2,04 & 0,4 & 1,33 & 0,3 \\
\hline 32 Serviços Industriais de Utilidade Pública & 21,24 & 3,1 & 24,58 & 4,5 & 16,53 & 3,2 \\
\hline 33 Construção Civil & 3,59 & 0,5 & 2,22 & 0,4 & 1,84 & 0,4 \\
\hline 34 Comércio & 53,12 & 7,8 & 39,93 & 7,4 & 35,09 & 6,8 \\
\hline 35 Supermercados & 303,57 & 44,3 & 202,64 & 37,4 & 188,45 & 36,7 \\
\hline 36 Transportes & 23,35 & 3,4 & 19,92 & 3,7 & 16,46 & 3,2 \\
\hline 37 Comunicações & 11,09 & 1,6 & 12,51 & 2,3 & 20,70 & 4,0 \\
\hline 38 Instituições Financeiras & 15,02 & 2,2 & 32,00 & 5,9 & 38,86 & 7,6 \\
\hline 39 Serviços Prestados às Famílias & 47,98 & 7,0 & 44,46 & 8,2 & 43,23 & 8,4 \\
\hline 40 Serviços Prestados às Empresas & 29,49 & 4,3 & 31,46 & 5,8 & 46,02 & 9,0 \\
\hline 41 Aluguel de Imóveis & 4,78 & 0,7 & 4,09 & 0,8 & 4,51 & 0,9 \\
\hline 42 Administração Pública & 32,07 & 4,7 & 21,29 & 3,9 & 18,26 & 3,6 \\
\hline 43 Serviços Privados não-mercantis & 17,52 & 2,6 & 20,16 & 3,7 & 17,55 & 3,4 \\
\hline Total & 685,13 & 100 & 541,48 & 100 & 513,43 & 100 \\
\hline
\end{tabular}


Tabela 43. Geração de renda por setor dada uma variação de $\mathrm{R} \$ 1$ milhão da demanda final do setor 35-Supermercados, valores em $\mathrm{R} \$$ mil (nova proposta metodológica).

\begin{tabular}{|c|c|c|c|c|c|c|c|c|c|}
\hline \multirow{2}{*}{\multicolumn{2}{|c|}{ Setor }} & \multicolumn{4}{|c|}{$1995 n$} & \multicolumn{4}{|c|}{$1999 n$} \\
\hline & & \multirow{2}{*}{$\begin{array}{r}\begin{array}{r}\text { direta e } \\
\text { indireta }\end{array} \\
24,55\end{array}$} & \multirow{2}{*}{$\begin{array}{r}\text { induzida } \\
9,62\end{array}$} & \multirow{2}{*}{$\frac{\text { total }}{34,17}$} & \multirow{2}{*}{$\frac{\%}{9,7}$} & \multirow{2}{*}{$\begin{array}{r}\begin{array}{r}\text { direta e } \\
\text { indireta }\end{array} \\
21,74\end{array}$} & \multirow{2}{*}{$\begin{array}{r}\text { induzida } \\
10,43\end{array}$} & \multirow{2}{*}{$\frac{\text { total }}{32,17}$} & \multirow{2}{*}{$\frac{\%}{8,1}$} \\
\hline 1 & Agropecuária & & & & & & & & \\
\hline 2 & Extrativa Mineral & 0,51 & 0,26 & 0,77 & 0,2 & 0,35 & 0,23 & 0,58 & 0,1 \\
\hline 3 & Petróleo e gás & 0,45 & 0,34 & 0,79 & 0,2 & 0,66 & 0,78 & 1,45 & 0,4 \\
\hline 4 & Minerais não-metálicos & 1,25 & 0,66 & 1,90 & 0,5 & 1,14 & 0,77 & 1,91 & 0,5 \\
\hline 5 & Siderurgia & 0,37 & 0,29 & 0,66 & 0,2 & 0,22 & 0,22 & 0,44 & 0,1 \\
\hline 6 & Metalurgia de não-ferrosos & 0,28 & 0,18 & 0,46 & 0,1 & 0,20 & 0,15 & 0,34 & 0,1 \\
\hline 7 & Outros Produtos Metalúrgicos & 3,88 & 2,39 & 6,26 & 1,8 & 2,91 & 2,23 & 5,15 & 1,3 \\
\hline 8 & Máquinas e Equipamentos & 2,74 & 1,85 & 4,59 & 1,3 & 1,78 & 1,68 & 3,46 & 0,9 \\
\hline 9 & Material Elétrico & 2,02 & 1,03 & 3,06 & 0,9 & 1,35 & 0,87 & 2,21 & 0,6 \\
\hline 10 & Equipamentos Eletrônicos & 1,79 & 1,05 & 2,84 & 0,8 & 1,21 & 0,68 & 1,89 & 0,5 \\
\hline 11 & Automóveis, caminhões e ônibus & 0,02 & 0,88 & 0,90 & 0,3 & 0,02 & 1,01 & 1,04 & 0,3 \\
\hline 12 & Peças e outros veículos & 0,64 & 2,00 & 2,63 & 0,7 & 0,43 & 1,86 & 2,29 & 0,6 \\
\hline 13 & Madeira e Mobiliário & 0,61 & 1,70 & 2,30 & 0,7 & 0,51 & 1,88 & 2,39 & 0,6 \\
\hline 14 & Celulose, Papel e Gráfica & 7,81 & 2,22 & 10,03 & 2,9 & 8,11 & 3,09 & 11,20 & 2,8 \\
\hline 15 & Indústria da Borracha & 0,25 & 0,44 & 0,69 & 0,2 & 0,18 & 0,41 & 0,59 & 0,1 \\
\hline 16 & Elementos Químicos & 0,81 & 0,88 & 1,70 & 0,5 & 0,77 & 0,99 & 1,76 & 0,4 \\
\hline 17 & Refino de Petróleo & 1,39 & 1,06 & 2,45 & 0,7 & 0,87 & 1,03 & 1,90 & 0,5 \\
\hline 18 & Químicos Diversos & 3,77 & 1,64 & 5,41 & 1,5 & 3,18 & 1,76 & 4,94 & 1,2 \\
\hline 19 & Farmacêuticos e Veterinários & 9,04 & 2,08 & 11,12 & 3,2 & 5,13 & 2,06 & 7,19 & 1,8 \\
\hline 20 & Artigos Plásticos & 1,80 & 0,90 & 2,70 & 0,8 & 2,11 & 1,42 & 3,53 & 0,9 \\
\hline 21 & Indústria Têxtil & 1,25 & 1,69 & 2,94 & 0,8 & 1,06 & 1,57 & 2,63 & 0,7 \\
\hline 22 & Artigos do Vestuário & 1,41 & 2,47 & 3,88 & 1,1 & 1,49 & 2,26 & 3,74 & 0,9 \\
\hline 23 & Calçados & 0,48 & 0,88 & 1,36 & 0,4 & 0,58 & 0,74 & 1,32 & 0,3 \\
\hline 24 & Indústria do Café & 0,87 & 0,28 & 1,14 & 0,3 & 0,64 & 0,22 & 0,86 & 0,2 \\
\hline 25 & Beneficiamento de Produtos Vegetais & 6,42 & 1,65 & 8,07 & 2,3 & 5,51 & 1,68 & 7,18 & 1,8 \\
\hline 26 & Abate de Animais & 3,94 & 1,48 & 5,41 & 1,5 & 3,07 & 1,57 & 4,64 & 1,2 \\
\hline 27 & Indústria de Laticínios & 2,88 & 0,53 & 3,40 & 1,0 & 2,99 & 0,56 & 3,55 & 0,9 \\
\hline 28 & Fabricação de Açúcar & 1,34 & 0,45 & 1,80 & 0,5 & 1,35 & 0,52 & 1,87 & 0,5 \\
\hline 29 & Fabricação de Óleos Vegetais & 1,11 & 0,27 & 1,38 & 0,4 & 0,76 & 0,27 & 1,03 & 0,3 \\
\hline 30 & Outros Produtos Alimentares & 13,26 & 3,64 & 16,90 & 4,8 & 12,11 & 4,01 & 16,12 & 4,0 \\
\hline 31 & Indústrias Diversas & 1,70 & 0,99 & 2,69 & 0,8 & 1,27 & 0,84 & 2,11 & 0,5 \\
\hline 32 & Serviços Industriais de Utilidade Pública & 6,18 & 8,43 & 14,61 & 4,2 & 4,80 & 9,15 & 13,95 & 3,5 \\
\hline 33 & Construção Civil & 0,41 & 0,52 & 0,93 & 0,3 & 0,32 & 0,61 & 0,92 & 0,2 \\
\hline 34 & Comércio & 12,04 & 22,66 & 34,70 & 9,9 & 26,28 & 46,10 & 72,39 & 18,1 \\
\hline 35 & Supermercados & 31,78 & 2,49 & 34,27 & 9,8 & 23,31 & 2,32 & 25,63 & 6,4 \\
\hline 36 & Transportes & 10,59 & 9,83 & 20,42 & 5,8 & 9,42 & 12,56 & 21,98 & 5,5 \\
\hline 37 & Comunicações & 2,61 & 3,27 & 5,88 & 1,7 & 4,45 & 9,35 & 13,80 & 3,5 \\
\hline & Instituições Financeiras & 6,20 & 12,34 & 18,55 & 5,3 & 8,10 & 16,66 & 24,76 & 6,2 \\
\hline & Serviços Prestados às Famílias & 2,55 & 26,61 & 29,16 & 8,3 & 2,02 & 34,94 & 36,96 & 9,3 \\
\hline & Serviços Prestados às Empresas & 9,30 & 5,63 & 14,93 & 4,2 & 12,82 & 10,34 & 23,17 & 5,8 \\
\hline & Aluguel de Imóveis & 0,29 & 1,94 & 2,23 & 0,6 & 0,25 & 3,10 & 3,35 & 0,8 \\
\hline & Administração Pública & 12,59 & 5,43 & 18,02 & 5,1 & 9,74 & 5,91 & 15,65 & 3,9 \\
\hline & Serviços Privados não-mercantis & 0,00 & 13,25 & 13,25 & 3,8 & 0,00 & 15,50 & 15,50 & 3,9 \\
\hline Tot & & 193,20 & 158,15 & 351,36 & 100 & 185,22 & 214,32 & 399,54 & 100 \\
\hline
\end{tabular}




\subsection{Geração de Imposto sobre Circulação de Mercadorias e Serviços}

A arrecadação do Imposto sobre Circulação de Mercadorias e Serviços (ICMS) é um dos principais componentes da receita dos estados. Portanto, torna-se importante a identificação e análise dos principais setores capazes de aumentar a geração deste imposto para realizar previsões do comportamento da receita quando do aumento ou diminuição da produção de determinados setores.

A exemplo do multiplicador de renda, foi calculado o valor total em reais gerado a partir de um aumento da demanda final de um milhão de reais para cada setor, cujos valores se encontram na Tabela 44. É importante salientar que os valores englobam efeitos diretos, indiretos e induzidos, portanto, o valor total de imposto gerado em toda a economia considerando-se a variação da demanda final.

Os resultados mostram que a capacidade de geração de imposto para os diversos setores variou substancialmente, como nos casos dos setores 33-Construção civil e 32Serviços industriais de utilidade pública Estes setores passaram, respectivamente, do primeiro e terceiro lugares na classificação em 1995 para décimo e vigésimo lugares em 1999. Posições baseadas em resultados obtidos utilizando as matrizes que possuem o setor 35-Supermercados desagregado pela metodologia tradicional. Os valores obtidos com a nova proposta metodológica se aproximam dos calculados com o setor 35Supermercados desagregado utilizando a metodologia tradicional, com exceção dos 35Supermercados e 34-Comércio.

As médias dos valores apresentam crescimento nas duas séries de resultados para as duas metodologias, indicando um aumento da capacidade de geração de imposto (ICMS). Analisando especificamente os valores do setor 35-Supermercados, nota-se que este possui grande importância na geração do Imposto sobre Circulação de Mercadorias e Serviços (ICMS), assumindo o primeiro lugar em 1995 e quarta posição na classificação em 1999, considerando os valores obtidos pela nova proposta metodológica para análise do setor.

A nova metodologia permite mensurar os efeitos indiretos e induzidos adicionais relativos aos setores fornecedores de bens e serviços ao próprio setor supermercadista e 
demais setores que fazem parte da cadeia de comercialização de seus produtos. A capacidade de geração de ICMS do setor supermercadista, nas duas metodologias, aumentou no período.

Os resultados para o setor 34-Comércio apresentam valores muito diferentes nas duas metodologias, conseqüência do maior efeito induzido característico da nova proposta metodológica sobre a economia. Além do setor 34-Comércio, outros setores apresentam o efeito de aumento do valor total gerado de imposto promovido pela nova metodologia. Pode-se citar como os mais influenciados os setores 42-Administração pública, 13-Madeira e mobiliário, 22-Artigos do vestuário, 39-Serviços prestados às famílias e 43-Serviços privados não-mercantis.

Alguns setores têm destaque na capacidade de geração de imposto (ICMS): 10Equipamentos eletrônicos, 11-Automóveis, caminhões e ônibus, 22-Artigos do vestuário, 23-Calçados e 27-Indústria de laticínios. Estes setores foram os que tiveram grande influência nas transformações da economia brasileira após a implementação do Plano Real de 1994. Pode-se notar que os valores de geração de imposto para estas indústrias aumentam consideravelmente no período 1995/99, enquanto no período 1990/95 as variações não são significativas. 
Tabela 44. Capacidade de geração de ICMS total para um aumento de produção R\$ 1 milhão (valores em R \$ mil, “o" é ordenação).

\begin{tabular}{|c|c|c|c|c|c|c|c|c|c|c|c|}
\hline \multirow{2}{*}{\multicolumn{2}{|c|}{ Setor }} & \multicolumn{2}{|c|}{1990} & \multicolumn{2}{|c|}{1995} & \multicolumn{2}{|c|}{1999} & \multicolumn{2}{|c|}{$1995 n$} & \multicolumn{2}{|c|}{$1999 n$} \\
\hline & & $\mathrm{o}$ & valor & o & valor & o & valor & o & valor & o & valor \\
\hline 1 & Agropecuária & 7 & 41,35 & 9 & 44,50 & 38 & 53,84 & 10 & 47,24 & 39 & 68,54 \\
\hline 2 & Extrativa Mineral & 24 & 26,14 & 21 & 31,17 & 30 & 63,87 & 23 & 36,46 & 33 & 78,27 \\
\hline 3 & Petróleo e gás & 37 & 20,90 & 29 & 28,85 & 40 & 48,19 & 29 & 33,00 & 40 & 60,75 \\
\hline 4 & Minerais não-metálicos & 26 & 25,37 & 27 & 29,36 & 4 & 89,82 & 27 & 33,58 & 8 & 104,32 \\
\hline 5 & Siderurgia & 29 & 24,24 & 31 & 27,43 & 23 & 67,10 & 33 & 30,81 & 30 & 79,85 \\
\hline 6 & Metalurgia de não-ferrosos & 35 & 21,95 & 36 & 24,90 & 17 & 75,19 & 38 & 27,98 & 20 & 88,60 \\
\hline 7 & Outros Produtos Metalúrgicos & 23 & 26,73 & 28 & 29,32 & 18 & 74,98 & 26 & 34,99 & 19 & 90,21 \\
\hline 8 & Máquinas e Equipamentos & 33 & 23,37 & 35 & 25,01 & 31 & 63,82 & 34 & 29,76 & 32 & 78,37 \\
\hline 9 & Material Elétrico & 32 & 23,58 & 32 & 26,89 & 12 & 82,90 & 32 & 31,40 & 15 & 98,03 \\
\hline 10 & Equipamentos Eletrônicos & 41 & 18,60 & 42 & 19,91 & 21 & 70,56 & 42 & 22,86 & 24 & 84,33 \\
\hline 11 & Automóveis, caminhões e ônibus & 31 & 23,65 & 39 & 22,94 & 6 & 88,84 & 39 & 26,66 & 9 & 104,01 \\
\hline 12 & Peças e outros veículos & 27 & 25,17 & 33 & 26,62 & 9 & 86,93 & 31 & 31,81 & 11 & 102,83 \\
\hline 13 & Made & 19 & 29,36 & 20 & 32,37 & 15 & 77,33 & 20 & 37,93 & 17 & 95,18 \\
\hline 14 & Celul & 21 & 27,10 & 24 & 30,70 & 7 & 88,07 & 22 & 36,54 & 7 & 105,40 \\
\hline 15 & Indús & 40 & 19,49 & 40 & 22,87 & 5 & 88,85 & 40 & 26,12 & 10 & 103,03 \\
\hline 16 & Elem & 22 & 26,72 & 25 & 30,00 & 34 & 59,59 & 28 & 33,20 & 36 & 72,36 \\
\hline 17 & Refin & 43 & 16,06 & 41 & 20,58 & 41 & 46,57 & 41 & 22,86 & 42 & 57,82 \\
\hline 18 & Quín & 39 & 20,11 & 37 & 24,55 & 37 & 56,43 & 36 & 28,51 & 37 & 69,96 \\
\hline 19 & Farn & 30 & 23,98 & 30 & 28,60 & 24 & 66,69 & 30 & 32,77 & 27 & 82,58 \\
\hline 20 & Arti & 38 & 20,19 & 38 & 24,37 & 36 & 58,23 & 37 & 28,16 & 35 & 72,46 \\
\hline 21 & Indú & 36 & 21,06 & 34 & 25,35 & 19 & 71,54 & 35 & 29,00 & 21 & 86,95 \\
\hline 22 & Artig & 25 & 25,73 & 26 & 29,69 & 2 & 98,33 & 21 & 36,84 & 3 & 116,39 \\
\hline 23 & Calça & 20 & 28,09 & 23 & 30,83 & 3 & 89,90 & 25 & 36,20 & 5 & 107,27 \\
\hline 24 & Indúst & 12 & 34,07 & 17 & 35,71 & 33 & 59,61 & 18 & 38,86 & 34 & 74,57 \\
\hline 25 & Benefi & 15 & 32,27 & 14 & 37,47 & 32 & 63,19 & 14 & 41,20 & 29 & 80,29 \\
\hline 26 & Abat & 10 & 36,66 & 11 & 39,23 & 26 & 66,19 & 12 & 42,91 & 25 & 83,46 \\
\hline 27 & Indús & 13 & 33,94 & 16 & 36,98 & 1 & 130,11 & 16 & 40,26 & 1 & 144,54 \\
\hline 28 & Fabric & 17 & 31,58 & 13 & 37,71 & 11 & 84,00 & 13 & 42,22 & 12 & 100,44 \\
\hline 29 & Fabrica & 14 & 33,40 & 15 & 37,20 & 16 & 77,19 & 15 & 40,55 & 18 & 93,53 \\
\hline 30 & Outros & 18 & 31,01 & 18 & 35,09 & 13 & 82,04 & 17 & 39,56 & 13 & 99,94 \\
\hline 31 & Indús & 28 & 24,46 & 22 & 30,92 & 22 & 67,49 & 24 & 36,32 & 26 & 82,91 \\
\hline 32 & Serviços Industriais de Utilidade Pública & 3 & 57,69 & 1 & 81,95 & 10 & 86,55 & 2 & 88,27 & 14 & 99,15 \\
\hline 33 & ç̧ão Civil & 1 & 93,74 & 2 & 81,27 & 20 & 71,18 & 4 & 84,59 & 23 & 84,77 \\
\hline 34 & Comércio & 11 & 36,65 & 8 & 47,06 & 25 & 66,39 & 9 & 54,41 & 2 & 144,38 \\
\hline 35 & Supermercados & 6 & 41,94 & 6 & 53,08 & 27 & 65,93 & 1 & 101,12 & 4 & 110,13 \\
\hline 36 & Transportes & 4 & 57,43 & 4 & 65,61 & 14 & 78,41 & 5 & 72,12 & 16 & 95,28 \\
\hline 37 & Comunicações & 16 & 33,37 & 19 & 33,22 & 42 & 45,88 & 19 & 38,14 & 41 & 59,08 \\
\hline 38 & Instituições Financeiras & 34 & 21,98 & 12 & 38,57 & 39 & 52,58 & 11 & 46,62 & 38 & 68,62 \\
\hline 39 & Serviços Prestados às Famílias & 2 & 82,16 & 3 & 77,75 & 8 & 87,81 & 3 & 85,41 & 6 & 106,37 \\
\hline 40 & Serviços Prestados às Empresas & 9 & 39,02 & 7 & 48,28 & 28 & 65,51 & 7 & 56,59 & 28 & 82,14 \\
\hline 41 & Aluguel de Imóveis & 42 & 16,63 & 43 & 19,20 & 43 & 28,62 & 43 & 19,83 & 43 & 38,94 \\
\hline 42 & Administração Pública & 5 & 45,67 & 5 & 54,47 & 29 & 64,99 & 6 & 66,04 & 22 & 85,18 \\
\hline & Serviços Privados não-mercantis & 8 & 39,79 & 10 & 42,87 & 35 & 58,35 & 8 & 56,33 & 31 & 78,59 \\
\hline Mé & & & 32,15 & & 36,5 & & 42,47 & & 71,39 & & 88,83 \\
\hline
\end{tabular}


Após a apresentação dos resultados para a produtividade do trabalho, capacidade de geração de emprego, renda e imposto para os setores da economia brasileira no período 1990/99, dever-se-ia considerar uma possível correlação dos valores calculados, principalmente entre a produtividade do trabalho medida em Valor adicionado a custo de fatores por trabalhador e a geração de renda. É importante afirmar que os indicadores econômicos não estão correlacionados, tal como se pode observar na Figura 10, na qual os valores de renda total gerada e produtividade do trabalho não apresentam nenhuma correlação.

A capacidade de geração de renda, assim como os outros indicadores econômicos calculados, dependem dos coeficientes técnicos obtidos a partir da matriz de insumoproduto e das ligações entre setores e demanda final. Portanto, os valores dos indicadores econômicos não apresentam uma correlação linear, quadrática ou de qualquer outro tipo.

Em relação aos índices de ligações intersetoriais, que serão apresentados a seguir, estes podem apresentar correlação linear, pois a ordenação dos setores utilizando os resultados para os índices Rasmussen-Hirschman e puros normalizados deve ser aproximadamente a mesma. Essa condição seria desejável, pois os diferentes índices indicariam os mesmos setores-chave para a economia.

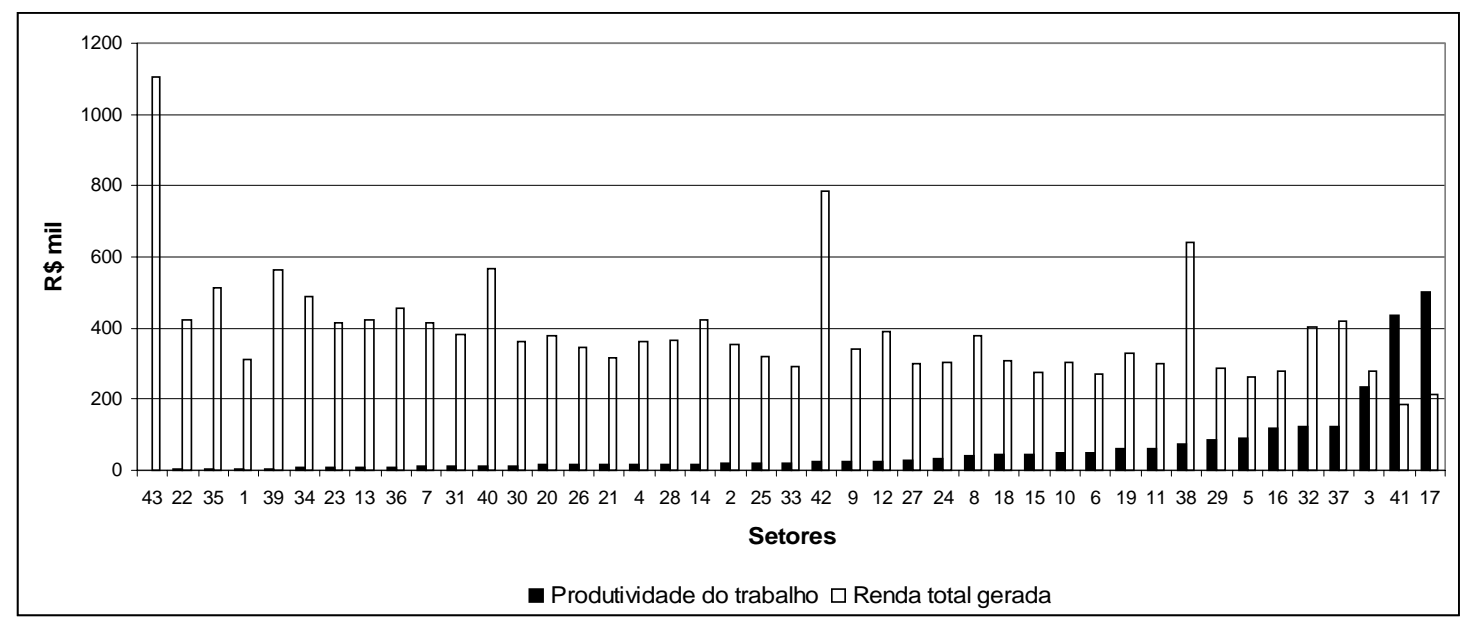

Figura 10 - Produtividade do trabalho e capacidade de geração de renda dos setores da economia para o ano de 1999n (nova proposta metodológica). 


\subsection{Multiplicadores de produção e índices de ligações intersetoriais}

\subsubsection{Multiplicadores de produção}

Os multiplicadores de produção dos tipos I e II calculados utilizando as duas metodologias descritas no capítulo teórico constam das Tabelas 45 e 46 . A interpretação dos resultados segue o mesmo raciocínio para os outros multiplicadores de emprego e renda. Portanto, o multiplicador tipo I para o setor 1-Agropecuária para o ano de 1999 da Tabela 45 indica que para cada unidade monetária de aumento de produção no próprio setor será gerado outro $\mathrm{R}$ \$ 1,73 em valor de produção nos outros setores da economia. A análise dos multiplicadores de produção indica que os setores 26-Abate de animais, 42Administração pública e 22-Artigos do vestuário apresentam os maiores valores para o período 1990/99. As médias dos valores obtidos mostram que houve um pequeno aumento dos multiplicadores de produção, porém, com fortes variações em alguns setores, como nos casos da 1-Agropecuária, 36-Transportes, 38-Instituições financeiras 34-Comércio e 41-Aluguel de imóveis. Notadamente, os setores de serviços sofreram as maiores variações dos valores apresentados nas Tabelas 45 e 46, indicando um crescimento da importância destes setores na economia, principalmente no período $1995 / 99$.

As médias dos valores calculados para as duas metodologias diferem novamente pelos números que surgem pelo maior efeito induzido da incorporação dos valores a preços básicos dos produtos comercializados pelos supermercados em seus custos operacionais, principalmente para o ano de 1999. O setor 34-Comércio é o mais influenciado pela aplicação da nova metodologia, apresentando um forte efeito induzido. O efeito induzido adicional pode ser mensurado pela diferença entre os multiplicadores de produção tipo II em $1995(1,94-1,92$ = 0,02) e principalmente em 1999 (4,00-3,38 = 0,62). O setor supermercadista analisado utilizando-se as matrizes de insumo-produto incorporando a nova proposta metodológica apresenta altos valores dos multiplicadores de produção tipos I e II e está classificado na sexta posição no período 1995/99, portanto, assume um papel importante na economia. 
Tabela 45. Multiplicadores de produção tipos I e II e ordenação dos setores de acordo com os valores do multiplicador tipo II (metodologia tradicional).

\begin{tabular}{|c|c|c|c|c|c|c|c|c|c|}
\hline \multirow{2}{*}{ Setor } & \multicolumn{3}{|c|}{1990} & \multicolumn{3}{|c|}{1995} & \multicolumn{3}{|c|}{1999} \\
\hline & ordem & $\mathrm{I}$ & II & ordem & $\mathrm{I}$ & II & ordem & I & II \\
\hline Agropecuária & 41 & 1,76 & 2,78 & 38 & 1,62 & 2,90 & 34 & 1,73 & 3,16 \\
\hline Extrativa Mineral & 25 & 2,00 & 3,36 & 18 & 1,98 & 3,41 & 31 & 1,84 & 3,25 \\
\hline Petróleo e gás & 38 & 1,77 & 2,87 & 37 & 1,67 & 3,03 & 42 & 1,45 & 2,84 \\
\hline 4 Minerais não-metálicos & 22 & 2,17 & 3,40 & 21 & 2,00 & 3,34 & 28 & 1,93 & 3,29 \\
\hline Siderurgia & 6 & 2,74 & 3,84 & 8 & 2,52 & 3,68 & 10 & 2,49 & 3,64 \\
\hline Metalurgia de não-ferrosos & 21 & 2,41 & 3,44 & 29 & 2,12 & 3,20 & 23 & 2,26 & 3,37 \\
\hline Outros Produtos Metalúrgicos & 2 & 2,45 & 3,93 & 4 & 2,28 & 3,74 & 7 & 2,29 & 3,71 \\
\hline 8 Máquinas e Equipamentos & 19 & 2,14 & 3,51 & 32 & 1,78 & 3,15 & 37 & 1,70 & 3,14 \\
\hline 9 Material Elétrico & 17 & 2,33 & 3,62 & 16 & 2,20 & 3,50 & 22 & 2,18 & 3,40 \\
\hline 10 Equipamentos Eletrônicos & 37 & 1,96 & 3,01 & 42 & 1,66 & 2,67 & 40 & 1,70 & 2,90 \\
\hline 11 Automóveis, caminhões e ônibus & 1 & 2,64 & 3,94 & 22 & 2,18 & 3,32 & 35 & 2,04 & 3,16 \\
\hline 12 Peças e outros veículos & 3 & 2,42 & 3,91 & 10 & 2,25 & 3,64 & 20 & 2,11 & 3,42 \\
\hline 13 Madeira e Mobiliário & 14 & 2,20 & 3,67 & 15 & 2,00 & 3,50 & 16 & 1,96 & 3,52 \\
\hline 14 Celulose, Papel e Gráfica & 8 & 2,33 & 3,77 & 13 & 2,13 & 3,59 & 14 & 2,11 & 3,56 \\
\hline 15 Indústria da Borracha & 26 & 2,32 & 3,36 & 25 & 2,13 & 3,26 & 30 & 2,10 & 3,25 \\
\hline 16 Elementos Químicos & 28 & 2,18 & 3,26 & 30 & 1,94 & 3,18 & 33 & 1,88 & 3,16 \\
\hline 17 Refino de Petróleo & 39 & 2,02 & 2,84 & 40 & 1,79 & 2,80 & 39 & 1,90 & 3,02 \\
\hline 18 Químicos Diversos & 32 & 2,09 & 3,17 & 27 & 2,07 & 3,24 & 29 & 2,07 & 3,29 \\
\hline 19 Farmacêuticos e Veterinários & 35 & 2,01 & 3,11 & 36 & 1,83 & 3,08 & 32 & 1,87 & 3,21 \\
\hline 20 Artigos Plásticos & 31 & 2,05 & 3,17 & 34 & 1,91 & 3,14 & 26 & 2,01 & 3,35 \\
\hline 21 Indústria Têxtil & 20 & 2,38 & 3,45 & 20 & 2,22 & 3,38 & 15 & 2,37 & 3,55 \\
\hline 22 Artigos do Vestuário & 4 & 2,32 & 3,87 & 2 & 2,18 & 3,76 & 2 & 2,17 & 3,76 \\
\hline 23 Calçados & 5 & 2,46 & 3,86 & 12 & 2,19 & 3,60 & 19 & 2,03 & 3,47 \\
\hline 24 Indústria do Café & 11 & 2,57 & 3,70 & 6 & 2,40 & 3,69 & 4 & 2,35 & 3,73 \\
\hline 25 Beneficiamento de Produtos Vegetais & 24 & 2,27 & 3,38 & 17 & 2,20 & 3,49 & 18 & 2,15 & 3,51 \\
\hline 26 Abate de Animais & 12 & 2,54 & 3,68 & 7 & 2,36 & 3,68 & 1 & 2,44 & 3,86 \\
\hline 27 Indústria de Laticínios & 9 & 2,66 & 3,76 & 5 & 2,43 & 3,70 & 17 & 2,25 & 3,51 \\
\hline 28 Fabricação de Açúcar & 15 & 2,46 & 3,64 & 1 & 2,44 & 3,80 & 5 & 2,34 & 3,72 \\
\hline 29 Fabricação de Óleos Vegetais & 7 & 2,68 & 3,78 & 3 & 2,52 & 3,75 & 8 & 2,40 & 3,69 \\
\hline 30 Outros Produtos Alimentares & 13 & 2,43 & 3,68 & 11 & 2,30 & 3,63 & 9 & 2,25 & 3,65 \\
\hline 31 Indústrias Diversas & 27 & 1,97 & 3,26 & 19 & 1,91 & 3,40 & 27 & 1,91 & 3,32 \\
\hline 32 Serviços Industriais de Utilidade Pública & 33 & 1,75 & 3,15 & 35 & 1,58 & 3,11 & 36 & 1,64 & 3,15 \\
\hline 33 Construção Civil & 36 & 1,88 & 3,09 & 39 & 1,63 & 2,83 & 38 & 1,68 & 3,05 \\
\hline 34 Comércio & 30 & 1,60 & 3,20 & 26 & 1,55 & 3,25 & 12 & 1,80 & 3,60 \\
\hline 35 Supermercados & 23 & 1,59 & 3,40 & 24 & 1,56 & 3,29 & 21 & 1,67 & 3,41 \\
\hline 36 Transportes & 29 & 1,75 & 3,21 & 33 & 1,65 & 3,15 & 13 & 1,93 & 3,56 \\
\hline 37 Comunicações & 40 & 1,31 & 2,84 & 41 & 1,24 & 2,71 & 41 & 1,27 & 2,85 \\
\hline 38 Instituições Financeiras & 42 & 1,18 & 2,47 & 31 & 1,35 & 3,16 & 24 & 1,44 & 3,37 \\
\hline 39 Serviços Prestados às Famílias & 18 & 1,76 & 3,51 & 23 & 1,62 & 3,30 & 11 & 1,73 & 3,62 \\
\hline 40 Serviços Prestados às Empresas & 34 & 1,47 & 3,12 & 28 & 1,41 & 3,21 & 25 & 1,46 & 3,36 \\
\hline 41 Aluguel de Imóveis & 43 & 1,18 & 1,90 & 43 & 1,09 & 2,19 & 43 & 1,07 & 2,41 \\
\hline 42 Administração Pública & 10 & 1,41 & 3,74 & 9 & 1,47 & 3,65 & 3 & 1,43 & 3,76 \\
\hline 43 Serviços Privados não-mercantis & 16 & 1,15 & 3,63 & 14 & 1,12 & 3,56 & 6 & 1,12 & 3,71 \\
\hline Média & & 2,06 & 3,38 & & 1,92 & 3,32 & & 1,92 & 3,38 \\
\hline
\end{tabular}


Tabela 46. Multiplicadores de produção tipos I e II e ordenação (o) dos setores de acordo com os valores do multiplicador tipo II (nova proposta metodológica).

\begin{tabular}{|c|c|c|c|c|c|c|}
\hline \multirow{2}{*}{ Setor } & \multicolumn{3}{|c|}{$1995 n$} & \multicolumn{3}{|c|}{$1999 n$} \\
\hline & ordem & I & II & ordem & I & II \\
\hline 1 Agropecuária & 38 & 1,62 & 2,81 & 34 & 1,77 & 3,70 \\
\hline 2 Extrativa Mineral & 19 & 1,98 & 3,44 & 31 & 1,88 & 3,77 \\
\hline 3 Petróleo e gás & 37 & 1,67 & 3,01 & 42 & 1,47 & 3,30 \\
\hline 4 Minerais não-metálicos & 25 & 2,00 & 3,32 & 28 & 1,97 & 3,82 \\
\hline 5 Siderurgia & 9 & 2,52 & 3,65 & 18 & 2,53 & 4,11 \\
\hline 6 Metalurgia de não-ferrosos & 32 & 2,12 & 3,17 & 27 & 2,31 & 3,87 \\
\hline 7 Outros Produtos Metalúrgicos & 5 & 2,28 & 3,79 & 12 & 2,34 & 4,27 \\
\hline 8 Máquinas e Equipamentos & 33 & 1,78 & 3,16 & 35 & 1,74 & 3,67 \\
\hline 9 Material Elétrico & 17 & 2,20 & 3,51 & 23 & 2,24 & 3,95 \\
\hline 10 Equipamentos Eletrônicos & 42 & 1,66 & 2,64 & 40 & 1,75 & 3,40 \\
\hline 11 Automóveis, caminhões e ônibus & 26 & 2,18 & 3,31 & 33 & 2,11 & 3,72 \\
\hline 12 Peças e outros veículos & 8 & 2,25 & 3,67 & 21 & 2,17 & 4,00 \\
\hline 13 Madeira e Mobiliário & 16 & 2,00 & 3,53 & 14 & 2,02 & 4,17 \\
\hline 14 Celulose, Papel e Gráfica & 11 & 2,13 & 3,64 & 13 & 2,17 & 4,19 \\
\hline 15 Indústria da Borracha & 30 & 2,13 & 3,23 & 32 & 2,16 & 3,77 \\
\hline 16 Elementos Químicos & 34 & 1,94 & 3,13 & 36 & 1,91 & 3,62 \\
\hline 17 Refino de Petróleo & 40 & 1,79 & 2,74 & 39 & 1,92 & 3,43 \\
\hline 18 Químicos Diversos & 29 & 2,07 & 3,24 & 30 & 2,12 & 3,78 \\
\hline 19 Farmacêuticos e Veterinários & 36 & 1,83 & 3,08 & 29 & 1,93 & 3,79 \\
\hline 20 Artigos Plásticos & 35 & 1,91 & 3,12 & 26 & 2,06 & 3,87 \\
\hline 21 Indústria Têxtil & 22 & 2,22 & 3,37 & 17 & 2,43 & 4,12 \\
\hline 22 Artigos do Vestuário & 2 & 2,18 & 3,87 & 5 & 2,23 & 4,42 \\
\hline 23 Calçados & 13 & 2,19 & 3,63 & 19 & 2,10 & 4,11 \\
\hline 24 Indústria do Café & 15 & 2,40 & 3,62 & 11 & 2,39 & 4,27 \\
\hline 25 Beneficiamento de Produtos Vegetais & 18 & 2,20 & 3,46 & 16 & 2,22 & 4,13 \\
\hline 26 Abate de Animais & 12 & 2,36 & 3,64 & 2 & 2,51 & 4,49 \\
\hline 27 Indústria de Laticínios & 10 & 2,43 & 3,64 & 20 & 2,30 & 4,03 \\
\hline 28 Fabricação de Açúcar & 4 & 2,44 & 3,80 & 7 & 2,41 & 4,32 \\
\hline 29 Fabricação de Óleos Vegetais & 7 & 2,52 & 3,70 & 10 & 2,47 & 4,29 \\
\hline 30 Outros Produtos Alimentares & 14 & 2,30 & 3,63 & 8 & 2,33 & 4,30 \\
\hline 31 Indústrias Diversas & 20 & 1,91 & 3,43 & 25 & 1,95 & 3,88 \\
\hline 32 Serviços Industriais de Utilidade Pública & 31 & 1,58 & 3,18 & 37 & 1,65 & 3,60 \\
\hline 33 Construção Civil & 39 & 1,63 & 2,79 & 38 & 1,71 & 3,54 \\
\hline 34 Comércio & 23 & 1,55 & 3,34 & 1 & 2,44 & 6,56 \\
\hline 35 Supermercados & 6 & 2,56 & 3,76 & 6 & 2,69 & 4,39 \\
\hline 36 Transportes & 28 & 1,65 & 3,24 & 15 & 1,98 & 4,17 \\
\hline 37 Comunicações & 41 & 1,24 & 2,71 & 41 & 1,28 & 3,33 \\
\hline 38 Instituições Financeiras & 27 & 1,35 & 3,27 & 24 & 1,45 & 3,95 \\
\hline 39 Serviços Prestados às Famílias & 21 & 1,62 & 3,41 & 9 & 1,77 & 4,29 \\
\hline 40 Serviços Prestados às Empresas & 24 & 1,41 & 3,34 & 22 & 1,48 & 3,96 \\
\hline 41 Aluguel de Imóveis & 43 & 1,09 & 2,01 & 43 & 1,07 & 2,78 \\
\hline 42 Administração Pública & 1 & 1,47 & 3,90 & 3 & 1,45 & 4,48 \\
\hline 43 Serviços Privados não-mercantis & 3 & 1,12 & 3,87 & 4 & 1,12 & 4,43 \\
\hline Média & & 1,94 & 3,34 & & 2,00 & 4,00 \\
\hline
\end{tabular}


As Tabelas 47 e 48 apresentam a decomposição do multiplicador de produção do setor 35-Supermercados. A análise dos resultados permite identificar os principais setores que sofrem influência da variação da demanda final dos supermercados sobre sua produção. A Tabela 47 possui valores calculados pela metodologia tradicional e a seguinte resume os resultados obtidos utilizando a matriz de insumo-produto para os anos de 1995/99 incorporando a nova proposta metodológica. A decomposição do multiplicador tipo II para o ano de 1999 (Tabela 48) permite constatar que para cada R\$ 1,00 de aumento de produção do setor supermercadista o aumento da produção do setor 1-Agropecuária seria de $\mathrm{R} \$ 0,474$, o maior valor para aquele ano com exceção do próprio setor 35-Supermercados.

Pode-se notar analisando os valores da Tabela 47 que os principais setores que sentiriam o impacto da variação da demanda final dos supermercados no ano de 1990 seriam 34-Comércio, 39-Serviços prestados às famílias, 1-Agropecuária, 41-Aluguel de imóveis e 17-Refino de petróleo. Os resultados para o ano de 1995 indicam os principais setores como sendo 41-Aluguel de imóveis, 39-Serviços prestados às famílias, 34Comércio, 1-Agropecuária e 32-Serviços industriais de utilidade pública. Para o ano de 1999, são listados os mesmos setores que em 1995, porém, assume maior importância 40-Serviços prestados às empresas, o que indica maiores gastos dos supermercados com serviços como consultoria e propaganda.

A classificação dos setores mais importantes pelos valores da Tabela 47 incorpora os efeitos diretos, indiretos e induzidos do aumento das vendas do setor 35Supermercados sobre a produção dos outros setores. Porém, não se considera nesta análise o impacto da aquisição dos produtos comercializados nos supermercados, e sim tão somente a maior demanda por produtos e serviços constituintes de seus custos operacionais.

Os supermercados comercializam principalmente alimentos, como foi analisado anteriormente, assim, seria de se esperar que entre os principais setores que sofreriam o impacto de uma variação de sua demanda final estaria a indústria alimentícia, diferentemente do que foi verificado nos resultados da Tabela 47. Quando as aquisições 
dos produtos vendidos a preços básicos são incorporadas como custos operacionais do setor 35-Supermercados, são obtidos os resultados da Tabela 48. Nota-se que os principais setores em 1995 passam a ser definidos como sendo 1-Agropecuária, 30Outros produtos alimentares, 34-Comércio, 25-Beneficiamento de produtos vegetais e 41-Aluguel de imóveis. Para o ano de 1999, permanecem como importantes os mesmos setores, porém, com maior destaque para 41-Aluguel de imóveis, considerando-se a classificação pelos valores do multiplicador tipo II, o qual engloba o efeito total (direto, indireto e induzido).

A classificação dos setores de maior influência sobre o produto pela variação da produção do setor supermercadista, considerando-se os efeitos direto e indireto (multiplicador tipo I) da Tabela 48, permite identificar a importância do setor 35Supermercados para 1-Agropecuária, 30-Outros produtos alimentares e 25Beneficiamento de produtos vegetais. Alguns setores, apesar de apresentarem valores relativamente menores, passam a ter os supermercados como um elo cada vez mais importante da cadeia de comercialização de seus produtos e como cliente de seus serviços, tais como 14-Celulose, papel e gráfica e 40-Serviços prestados às empresas.

Quando são levados em consideração os valores da nova proposta metodológica, o setor 14-Celulose, papel e gráfica fornece ao sistema de produção e comercialização do setor 35-Supermercados embalagens e produtos de papelaria, higiene e limpeza. Estes produtos são expostos nas seções de bazar e higiene e limpeza das lojas. O setor 40Serviços prestados às empresas compreende diversas atividades como seguros, propaganda, consultorias e serviços prestados à cadeia produtiva da qual os supermercados constituem o elo junto ao consumidor.

Os totais dos valores dos multiplicadores de produção das duas metodologias de análise apresentadas nas Tabelas 47 e 48 aumentam significativamente, indicando que o setor 35-Supermercados aumentou sua importância como equipamento de comercialização e setor comprador de bens e serviços. 
Tabela 47. Decomposição do multiplicador de produção tipos I e II do setor 35Supermercados, resultados para a metodologia tradicional.

\begin{tabular}{|c|c|c|c|c|c|c|c|c|c|}
\hline \multirow{2}{*}{ Setor } & \multicolumn{3}{|c|}{1990} & \multicolumn{3}{|c|}{1995} & \multicolumn{3}{|c|}{1999} \\
\hline & $\mathrm{o}$ & I & II & $\mathrm{o}$ & I & II & $\mathrm{o}$ & I & II \\
\hline 1 Agropecuária & & 0,007 & 0,183 & & 0,006 & 0,194 & & 0,006 & 0,178 \\
\hline 2 Extrativa Mineral & 43 & 0,001 & 0,007 & 43 & 0,001 & 0,005 & 43 & 0,001 & 0,004 \\
\hline 3 Petróleo e gás & 34 & 0,005 & 0,020 & 42 & 0,002 & 0,009 & 29 & 0,004 & 0,020 \\
\hline 4 Minerais não-metálicos & 38 & 0,004 & 0,017 & 36 & 0,003 & 0,014 & 36 & 0,003 & 0,012 \\
\hline 5 Siderurgia & 26 & 0,007 & 0,030 & 28 & 0,006 & 0,024 & 28 & 0,006 & 0,021 \\
\hline 6 Metalurgia de não-ferrosos & 40 & 0,003 & 0,015 & 38 & 0,002 & 0,010 & 39 & 0,002 & 0,009 \\
\hline 7 Outros Produtos Metalúrgicos & 23 & 0,007 & 0,033 & 21 & 0,008 & 0,030 & 22 & 0,008 & 0,026 \\
\hline 8 Máquinas e Equipamentos & 19 & 0,013 & 0,038 & 19 & 0,015 & 0,032 & 21 & 0,013 & 0,026 \\
\hline 9 Material Elétrico & 32 & 0,004 & 0,023 & 34 & 0,004 & 0,020 & 34 & 0,003 & 0,016 \\
\hline 10 Equipamentos Eletrônicos & 29 & 0,001 & 0,026 & 27 & 0,001 & 0,025 & 37 & 0,001 & 0,012 \\
\hline 11 Automóveis, caminhões e ônibus & 30 & 0,001 & 0,025 & 22 & 0,001 & 0,030 & 24 & 0,000 & 0,025 \\
\hline 12 Peças e outros veículos & 24 & 0,004 & 0,032 & 24 & 0,003 & 0,027 & 30 & 0,002 & 0,020 \\
\hline 13 Madeira e Mobiliário & 28 & 0,004 & 0,027 & 31 & 0,004 & 0,022 & 32 & 0,003 & 0,020 \\
\hline 14 Celulose, Papel e Gráfica & & 0,079 & 0,116 & 11 & 0,052 & 0,080 & 12 & 0,053 & 0,082 \\
\hline 15 Indústria da Borracha & 39 & 0,003 & 0,015 & 37 & 0,002 & 0,012 & 38 & 0,002 & 0,011 \\
\hline 16 Elementos Químicos & 22 & 0,005 & 0,033 & 26 & 0,003 & 0,026 & 23 & 0,004 & 0,026 \\
\hline 17 Refino de Petróleo & 6 & 0,027 & 0,122 & 10 & 0,017 & 0,083 & 9 & 0,023 & 0,112 \\
\hline 18 Químicos Diversos & 17 & 0,007 & 0,043 & 20 & 0,005 & 0,031 & 19 & 0,005 & 0,032 \\
\hline 19 Farmacêuticos e Veterinários & 27 & 0,001 & 0,029 & 23 & 0,000 & 0,028 & 20 & 0,001 & 0,032 \\
\hline 20 Artigos Plásticos & 20 & 0,020 & 0,037 & 29 & 0,012 & 0,024 & 27 & 0,012 & 0,023 \\
\hline 21 Indústria Têxtil & 11 & 0,008 & 0,072 & 16 & 0,005 & 0,044 & 17 & 0,004 & 0,036 \\
\hline 22 Artigos do Vestuário & 16 & 0,001 & 0,044 & 25 & 0,000 & 0,027 & 31 & 0,000 & 0,020 \\
\hline 23 Calçados & 37 & 0,000 & 0,018 & 41 & 0,000 & 0,009 & 42 & 0,000 & 0,007 \\
\hline 24 Indústria do Café & 42 & 0,000 & 0,007 & 39 & 0,000 & 0,010 & 41 & 0,000 & 0,008 \\
\hline 25 Beneficiamento de Produtos Vegetais & 18 & 0,001 & 0,043 & 15 & 0,001 & 0,045 & 15 & 0,001 & 0,044 \\
\hline 26 Abate de Animais & 15 & 0,001 & 0,047 & 17 & 0,001 & 0,043 & 14 & 0,001 & 0,045 \\
\hline 27 Indústria de Laticínios & 31 & 0,000 & 0,023 & 33 & 0,000 & 0,021 & 33 & 0,000 & 0,017 \\
\hline 28 Fabricação de Açúcar & 41 & 0,001 & 0,013 & 40 & 0,000 & 0,009 & 40 & 0,000 & 0,009 \\
\hline 29 Fabricação de Óleos Vegetais & 35 & 0,001 & 0,019 & 32 & 0,000 & 0,021 & 25 & 0,001 & 0,023 \\
\hline 30 Outros Produtos Alimentares & 13 & 0,002 & 0,062 & 12 & 0,002 & 0,066 & 13 & 0,002 & 0,062 \\
\hline 31 Indústrias Diversas & 36 & 0,004 & 0,019 & 35 & 0,004 & 0,015 & 35 & 0,004 & 0,014 \\
\hline 32 Serviços Industriais de Utilidade Pública & 10 & 0,033 & 0,096 & & 0,053 & 0,111 & & 0,051 & 0,125 \\
\hline 33 Construção Civil & 25 & 0,018 & 0,031 & 18 & 0,022 & 0,034 & 18 & 0,021 & 0,033 \\
\hline 34 Comércio & & 0,035 & 0,238 & & 0,027 & 0,196 & & 0,033 & 0,187 \\
\hline 35 Supermercados & 1 & 1,000 & 1,014 & & 1,000 & 1,019 & & 1,000 & 1,014 \\
\hline 36 Transportes & 7 & 0,035 & 0,121 & & 0,026 & 0,104 & 11 & 0,021 & 0,103 \\
\hline 37 Comunicações & 21 & 0,016 & 0,034 & 13 & 0,034 & 0,056 & 10 & 0,058 & 0,111 \\
\hline 38 Instituições Financeiras & 14 & 0,015 & 0,060 & & 0,040 & 0,098 & & 0,067 & 0,123 \\
\hline 39 Serviços Prestados às Famílias & 3 & 0,031 & 0,200 & & 0,018 & 0,200 & & 0,016 & 0,169 \\
\hline 40 Serviços Prestados às Empresas & 8 & 0,090 & 0,119 & & 0,075 & 0,103 & & 0,138 & 0,174 \\
\hline 41 Aluguel de Imóveis & 5 & 0,052 & 0,159 & & 0,071 & 0,254 & & 0,074 & 0,315 \\
\hline 42 Administração Pública & 12 & 0,043 & 0,069 & 14 & 0,030 & 0,050 & 16 & 0,029 & 0,042 \\
\hline 43 Serviços Privados não-mercantis & 33 & 0,000 & 0,021 & 30 & 0,000 & 0,024 & 26 & 0,000 & 0,023 \\
\hline Total & & 1,589 & 3,398 & & 1,558 & 3,287 & & 1,673 & 3,410 \\
\hline
\end{tabular}


Tabela 48. Decomposição do multiplicador de produção tipos I e II do setor 35Supermercados, resultados para a nova proposta metodológica.

\begin{tabular}{|c|c|c|c|c|c|c|c|}
\hline \multirow{2}{*}{\multicolumn{2}{|c|}{ Setores }} & \multicolumn{3}{|c|}{$1995 n$} & \multicolumn{3}{|c|}{$1999 n$} \\
\hline & & \multirow{2}{*}{$\begin{array}{c}\text { ordem } \\
2\end{array}$} & \multirow{2}{*}{$\frac{\mathrm{I}}{0,315}$} & \multirow{2}{*}{$\begin{array}{c}\text { II } \\
0,439\end{array}$} & \multirow{2}{*}{$\frac{\text { ordem }}{2}$} & \multirow{2}{*}{$\begin{array}{c}\mathrm{I} \\
0,320\end{array}$} & \multirow{2}{*}{$\begin{array}{c}\text { II } \\
0,474\end{array}$} \\
\hline 1 & Agropecuária & & & & & & \\
\hline 2 & Extrativa Mineral & 43 & 0,005 & 0,007 & 43 & 0,004 & 0,007 \\
\hline 3 & Petróleo e gás & 40 & 0,006 & 0,011 & 24 & 0,016 & 0,035 \\
\hline 4 & Minerais não-metálicos & 33 & 0,013 & 0,020 & 35 & 0,012 & 0,020 \\
\hline 5 & Siderurgia & 26 & 0,015 & 0,027 & 28 & 0,014 & 0,028 \\
\hline 6 & Metalurgia de não-ferrosos & 39 & 0,008 & 0,013 & 40 & 0,008 & 0,015 \\
\hline 7 & Outros Produtos Metalúrgicos & 22 & 0,023 & 0,037 & 22 & 0,021 & 0,037 \\
\hline 8 & Máquinas e Equipamentos & 25 & 0,017 & 0,028 & 30 & 0,014 & 0,027 \\
\hline 9 & Material Elétrico & 23 & 0,021 & 0,032 & 25 & 0,018 & 0,030 \\
\hline 10 & Equipamentos Eletrônicos & 20 & 0,027 & 0,042 & 31 & 0,016 & 0,026 \\
\hline 11 & Automóveis, caminhões e ônibus & 34 & 0,001 & 0,020 & 34 & 0,000 & 0,022 \\
\hline 12 & Peças e outros veículos & 32 & 0,005 & 0,021 & 36 & 0,004 & 0,020 \\
\hline 13 & Madeira e Mobiliário & 36 & 0,004 & 0,016 & 38 & 0,004 & 0,018 \\
\hline 14 & Celulose, Papel e Gráfica & 13 & 0,065 & 0,083 & 12 & 0,076 & 0,105 \\
\hline 15 & Indústria da Borracha & 41 & 0,004 & 0,010 & 41 & 0,004 & 0,012 \\
\hline 16 & Elementos Químicos & 24 & 0,014 & 0,029 & 21 & 0,020 & 0,046 \\
\hline 17 & Refino de Petróleo & 10 & 0,056 & 0,100 & 6 & 0,089 & 0,193 \\
\hline 18 & Químicos Diversos & 17 & 0,039 & 0,056 & 19 & 0,045 & 0,071 \\
\hline 19 & Farmacêuticos e Veterinários & 11 & 0,080 & 0,099 & 13 & 0,068 & 0,096 \\
\hline 20 & Artigos Plásticos & 30 & 0,016 & 0,024 & 32 & 0,015 & 0,025 \\
\hline 21 & Indústria Têxtil & 19 & 0,019 & 0,045 & 20 & 0,019 & 0,048 \\
\hline 22 & Artigos do Vestuário & 27 & 0,010 & 0,027 & 26 & 0,012 & 0,029 \\
\hline 23 & Calçados & 42 & 0,003 & 0,009 & 42 & 0,005 & 0,010 \\
\hline 24 & Indústria do Café & 29 & 0,019 & 0,026 & 27 & 0,021 & 0,029 \\
\hline 25 & Beneficiamento de Produtos Vegetais & 5 & 0,114 & 0,143 & 7 & 0,125 & 0,163 \\
\hline 26 & Abate de Animais & 9 & 0,075 & 0,103 & 10 & 0,077 & 0,116 \\
\hline 27 & Indústria de Laticínios & 12 & 0,075 & 0,089 & 14 & 0,078 & 0,093 \\
\hline 28 & Fabricação de Açúcar & 31 & 0,017 & 0,023 & 29 & 0,020 & 0,028 \\
\hline 29 & Fabricação de Óleos Vegetais & 14 & 0,055 & 0,069 & 17 & 0,057 & 0,077 \\
\hline 30 & Outros Produtos Alimentares & 3 & 0,154 & 0,196 & 5 & 0,163 & 0,217 \\
\hline 31 & Indústrias Diversas & 35 & 0,012 & 0,019 & 33 & 0,014 & 0,023 \\
\hline 32 & Serviços Industriais de Utilidade Pública & 15 & 0,028 & 0,066 & 11 & 0,036 & 0,106 \\
\hline 33 & Construção Civil & 38 & 0,006 & 0,014 & 39 & 0,006 & 0,017 \\
\hline 34 & Comércio & 4 & 0,059 & 0,170 & 4 & 0,080 & 0,220 \\
\hline 35 & Supermercados & 1 & 1,000 & 1,078 & 1 & 1,000 & 1,100 \\
\hline 36 & Transportes & 8 & 0,056 & 0,107 & 9 & 0,059 & 0,138 \\
\hline 37 & Comunicações & 28 & 0,012 & 0,026 & 18 & 0,024 & 0,074 \\
\hline 38 & Instituições Financeiras & 16 & 0,019 & 0,057 & 16 & 0,026 & 0,079 \\
\hline 39 & Serviços Prestados às Famílias & 7 & 0,011 & 0,131 & 8 & 0,008 & 0,145 \\
\hline 40 & Serviços Prestados às Empresas & 18 & 0,031 & 0,049 & 15 & 0,048 & 0,087 \\
\hline 41 & Aluguel de Imóveis & 6 & 0,018 & 0,139 & 3 & 0,018 & 0,234 \\
\hline 42 & Administração Pública & 21 & 0,029 & 0,042 & 23 & 0,023 & 0,036 \\
\hline 43 & Serviços Privados não-mercantis & 37 & 0,000 & 0,016 & 37 & 0,000 & 0,020 \\
\hline Tot & & & 2,558 & 3,760 & & 2,688 & 4,393 \\
\hline
\end{tabular}




\subsection{2 Índices de ligações intersetoriais}

Para identificar os setores-chave da economia brasileira no período 1990/99 foram calculados os índices de Rasmussen-Hirschman e os índices puros normalizados (GHS). Além disso, a abordagem do campo de influência foi utilizada para completar a análise.

Os índices de ligações intersetoriais apresentados são valores relativos à média da economia, pois as médias de cada série de índices são iguais a um. O resultado de 3,6 para o índice de Rasmussen-Hirschman para frente do setor 1-Agropecuária em 1999 (nova proposta metodológica) significa que este setor é demandado 3,6 vezes a média da economia por setores compradores de seus produtos. A diferença entre os dois índices é que o puro considera os montantes monetários dos fluxos intersetoriais, enquanto o índice de Rasmussen-Hirschman é obtido a partir dos coeficientes técnicos da matriz de insumo-produto.

Os valores dos índices de Rasmussen-Hirschman para o período 1990/99 constam das Tabelas 49 e 50. A primeira resume os resultados da metodologia tradicional para os anos de 1990, 1995 e 1999 e a segunda apresenta os valores para os anos de 1995 e 1999 para a nova proposta metodológica. Os valores foram utilizados para elaborar gráficos que facilitam a identificação dos principais setores: os números da Tabela 49 foram utilizados para elaborar as Figuras 11, 12 e 13. A partir dos resultados da Tabela 50, foram elaborados os gráficos das Figuras 14 e 15. Deve-se notar que os valores para os anos citados são calculados utilizando-se as duas metodologias de desagregação do setor 35-Supermercados.

Para identificar os setores-chave segundo os valores dos índices de ligações intersetoriais de Rasmussen-Hirschman deve-se observar as Figuras 11 a 15. Estas simplificam a tarefa de enumerar os setores que possuem maiores valores de ligações para trás e para frente. Nota-se que os principais setores com ligações intersetoriais para trás no período 1990/99, considerando os valores obtidos utilizando-se as duas metodologias de análise, são: 5-Siderurgia, 29-Fabricação de óleos vegetais, 24-Indústria do café, 27-Indústria de laticínios e 28-Fabricação de açúcar. Os resultados mostram que 
estes setores são importantes compradores para seus fornecedores de bens e serviços. Os setores com maiores ligações intersetoriais para frente são 1-Agropecuária, 17-Refino de petróleo e 5-Siderurgia. Estes se destacam como fornecedores de matéria-prima para os outros setores da economia, sendo demandados em maior intensidade (valor) em relação à média dos demais.

Os setores que apresentam valores dos índices maiores que um para trás e para frente no período considerado são 5-Siderurgia, 6-Metalurgia de não-ferrosos, 7-Outros produtos metalúrgicos, 14-Celulose, papel e gráfica, 18-Químicos diversos e 21Indústria têxtil. Deve-se destacar também o setor 36-Transportes que vem aumentando sua importância e, a partir de 1999, também passa a ter os dois índices, para frente e para trás, maiores que um. Os setores listados apresentam a característica comum de serem importantes fornecedores de bens e serviços para outras atividades e vendem uma parcela relativamente menor de sua produção para o consumidor final em comparação à média dos outros setores da economia. O setor 14-Celulose, papel e gráfica, por exemplo, é fornecedor de embalagens para outras indústrias e 18-Químicos diversos vende seus produtos a uma grande gama de empresas, incluindo higiene pessoal e perfumaria.

No caso do setor 35-Supermercados, quando este é analisado levando-se em consideração os produtos comercializados (nova proposta metodológica) torna-se possível mensurar seu índice de ligações para trás de forma mais eficiente. O valor da metodologia tradicional é 0,81 e 0,87 , respectivamente para os anos de 1995 e 1999 . Os valores obtidos pela nova metodologia são relativamente maiores: 1,32 e 1,36; passando a ser o setor com maior valor de índice para trás no período.

Os valores calculados para os índices de Rasmussen-Hirschman utilizando as matrizes de insumo-produto incorporando as duas metodologias de desagregação dos 35Supermercados são muito próximos para todos os setores da economia com exceção do próprio setor supermercadista. Os resultados permitem analisar melhor os índices de ligações intersetoriais do varejo, sem causar modificações na análise dos outros setores da economia. 
Tabela 49. Índices de ligações intersetoriais de Rasmussen-Hirschman (metodologia tradicional).

\begin{tabular}{|c|c|c|c|c|c|c|c|}
\hline \multirow{2}{*}{\multicolumn{2}{|c|}{ Setor }} & \multicolumn{2}{|c|}{1990} & \multicolumn{2}{|c|}{1995} & \multicolumn{2}{|c|}{1999} \\
\hline & & trás & frente & trás & frente & trás & frente \\
\hline 1 & Agropecuária & 0,85 & 3,06 & 0,85 & 3,46 & 0,90 & 3,14 \\
\hline 2 & Extrativa Mineral & 0,97 & 0,76 & 1,03 & 0,79 & 0,96 & 0,76 \\
\hline 3 & Petróleo e gás & 0,86 & 0,93 & 0,87 & 0,79 & 0,75 & 1,04 \\
\hline 4 & Minerais não-metálicos & 1,05 & 0,94 & 1,04 & 0,95 & 1,00 & 0,86 \\
\hline 5 & Siderurgia & 1,33 & 1,79 & 1,31 & 1,78 & 1,30 & 1,69 \\
\hline 6 & Metalurgia de não-ferrosos & 1,17 & 1,13 & 1,11 & 1,03 & 1,18 & 1,02 \\
\hline 7 & Outros Produtos Metalúrgicos & 1,19 & 1,32 & 1,19 & 1,32 & 1,19 & 1,13 \\
\hline 8 & Máquinas e Equipamentos & 1,04 & 1,37 & 0,93 & 1,18 & 0,89 & 0,99 \\
\hline 9 & Material Elétrico & 1,13 & 0,76 & 1,15 & 0,73 & 1,14 & 0,66 \\
\hline 10 & Equipamentos Eletrônicos & 0,95 & 0,68 & 0,86 & 0,61 & 0,89 & 0,60 \\
\hline 11 & Automóveis, caminhões e ônibus & 1,28 & 0,54 & 1,14 & 0,55 & 1,06 & 0,54 \\
\hline 12 & Peças e outros veículos & 1,17 & 1,00 & 1,17 & 0,95 & 1,10 & 0,80 \\
\hline 13 & Madeira e Mobiliário & 1,07 & 0,70 & 1,04 & 0,71 & 1,02 & 0,67 \\
\hline 14 & Celulose, Papel e Gráfica & 1,13 & 1,29 & 1,11 & 1,22 & 1,10 & 1,24 \\
\hline 15 & Indústria da Borracha & 1,12 & 0,90 & 1,11 & 0,92 & 1,10 & 0,81 \\
\hline 16 & Elementos Químicos & 1,05 & 0,89 & 1,01 & 0,91 & 0,98 & 0,97 \\
\hline 17 & Refino de Petróleo & 0,98 & 2,73 & 0,94 & 2,48 & 0,99 & 2,85 \\
\hline 18 & Químicos Diversos & 1,01 & 1,37 & 1,08 & 1,26 & 1,08 & 1,31 \\
\hline 19 & Farmacêuticos e Veterinários & 0,97 & 0,54 & 0,95 & 0,55 & 0,98 & 0,59 \\
\hline 20 & Artigos Plásticos & 1,00 & 0,87 & 1,00 & 0,84 & 1,05 & 0,81 \\
\hline 21 & Indústria Têxtil & 1,15 & 1,46 & 1,16 & 1,39 & 1,23 & 1,30 \\
\hline 22 & Artigos do Vestuário & 1,12 & 0,52 & 1,14 & 0,53 & 1,13 & 0,53 \\
\hline 23 & Calçados & 1,19 & 0,64 & 1,14 & 0,64 & 1,06 & 0,61 \\
\hline 24 & Indústria do Café & 1,24 & 0,64 & 1,25 & 0,71 & 1,22 & 0,64 \\
\hline 25 & Beneficiamento de Produtos Vegetais & 1,10 & 0,65 & 1,15 & 0,68 & 1,12 & 0,66 \\
\hline 26 & Abate de Animais & 1,23 & 0,64 & 1,23 & 0,68 & 1,27 & 0,64 \\
\hline 27 & Indústria de Laticínios & 1,29 & 0,65 & 1,27 & 0,67 & 1,17 & 0,63 \\
\hline 28 & Fabricação de Açúcar & 1,19 & 0,67 & 1,27 & 0,71 & 1,22 & 0,68 \\
\hline 29 & Fabricação de Óleos Vegetais & 1,30 & 0,76 & 1,31 & 0,80 & 1,25 & 0,81 \\
\hline 30 & Outros Produtos Alimentares & 1,18 & 0,70 & 1,20 & 0,74 & 1,17 & 0,73 \\
\hline 31 & Indústrias Diversas & 0,95 & 0,79 & 1,00 & 0,69 & 0,99 & 0,63 \\
\hline 32 & Serviços Industriais de Utilidade Pública & 0,85 & 1,47 & 0,83 & 1,46 & 0,85 & 1,71 \\
\hline 33 & Construção Civil & 0,91 & 0,66 & 0,85 & 0,68 & 0,88 & 0,67 \\
\hline 34 & Comércio & 0,77 & 1,79 & 0,81 & 1,71 & 0,94 & 2,07 \\
\hline 35 & Supermercados & 0,77 & 0,49 & 0,81 & 0,52 & 0,87 & 0,52 \\
\hline 36 & Transportes & 0,85 & 1,49 & 0,86 & 1,42 & 1,01 & 1,40 \\
\hline 37 & Comunicações & 0,63 & 0,68 & 0,65 & 0,73 & 0,66 & 0,99 \\
\hline 38 & Instituições Financeiras & 0,57 & 0,73 & 0,70 & 1,02 & 0,75 & 1,11 \\
\hline 39 & Serviços Prestados às Famílias & 0,85 & 0,85 & 0,85 & 0,83 & 0,90 & 0,73 \\
\hline 40 & Serviços Prestados às Empresas & 0,71 & 1,15 & 0,74 & 1,17 & 0,76 & 1,41 \\
\hline 41 & Aluguel de Imóveis & 0,57 & 0,64 & 0,57 & 0,79 & 0,56 & 0,76 \\
\hline 42 & Administração Pública & 0,68 & 0,89 & 0,77 & 0,87 & 0,74 & 0,78 \\
\hline 43 & Serviços Privados não-mercantis & 0,56 & 0,48 & 0,58 & 0,52 & 0,58 & 0,52 \\
\hline
\end{tabular}


Tabela 50. Índices de ligações intersetoriais de Rasmussen-Hirschman (nova proposta metodológica).

\begin{tabular}{|c|c|c|c|c|c|}
\hline \multirow{2}{*}{\multicolumn{2}{|c|}{ Setor }} & \multicolumn{2}{|c|}{$1995 n$} & \multicolumn{2}{|c|}{$1999 n$} \\
\hline & & \multirow{2}{*}{$\begin{array}{l}\text { trás } \\
0,84\end{array}$} & \multirow{2}{*}{$\begin{array}{r}\text { frente } \\
3,58\end{array}$} & \multirow{2}{*}{$\begin{array}{l}\text { trás } \\
0,89\end{array}$} & \multirow{2}{*}{$\begin{array}{r}\text { frente } \\
3,26\end{array}$} \\
\hline$\overline{1}$ & Agropecuária & & & & \\
\hline 2 & Extrativa Mineral & 1,02 & 0,78 & 0,95 & 0,75 \\
\hline 3 & Petróleo e gás & 0,86 & 0,79 & 0,75 & 1,03 \\
\hline 4 & Minerais não-metálicos & 1,03 & 0,95 & 0,99 & 0,86 \\
\hline 5 & Siderurgia & 1,30 & 1,77 & 1,28 & 1,67 \\
\hline 6 & Metalurgia de não-ferrosos & 1,09 & 1,02 & 1,17 & 1,01 \\
\hline 7 & Outros Produtos Metalúrgicos & 1,18 & 1,31 & 1,18 & 1,12 \\
\hline 8 & Máquinas e Equipamentos & 0,92 & 1,16 & 0,88 & 0,98 \\
\hline 9 & Material Elétrico & 1,13 & 0,73 & 1,12 & 0,66 \\
\hline 10 & Equipamentos Eletrônicos & 0,85 & 0,61 & 0,88 & 0,60 \\
\hline 11 & Automóveis, caminhões e ônibus & 1,12 & 0,54 & 1,05 & 0,54 \\
\hline 12 & Peças e outros veículos & 1,16 & 0,94 & 1,09 & 0,79 \\
\hline 13 & Madeira e Mobiliário & 1,03 & 0,70 & 1,01 & 0,66 \\
\hline 14 & Celulose, Papel e Gráfica & 1,10 & 1,21 & 1,09 & 1,24 \\
\hline 15 & Indústria da Borracha & 1,10 & 0,91 & 1,08 & 0,80 \\
\hline 16 & Elementos Químicos & 1,00 & 0,90 & 0,97 & 0,96 \\
\hline 17 & Refino de Petróleo & 0,92 & 2,47 & 0,98 & 2,84 \\
\hline 18 & Químicos Diversos & 1,06 & 1,27 & 1,07 & 1,32 \\
\hline 19 & Farmacêuticos e Veterinários & 0,94 & 0,59 & 0,96 & 0,62 \\
\hline 20 & Artigos Plásticos & 0,99 & 0,83 & 1,04 & 0,80 \\
\hline 21 & Indústria Têxtil & 1,15 & 1,38 & 1,22 & 1,29 \\
\hline 22 & Artigos do Vestuário & 1,12 & 0,53 & 1,12 & 0,53 \\
\hline 23 & Calçados & 1,13 & 0,64 & 1,05 & 0,60 \\
\hline 24 & Indústria do Café & 1,23 & 0,71 & 1,21 & 0,64 \\
\hline 25 & Beneficiamento de Produtos Vegetais & 1,13 & 0,73 & 1,11 & 0,72 \\
\hline 26 & Abate de Animais & 1,22 & 0,71 & 1,26 & 0,67 \\
\hline 27 & Indústria de Laticínios & 1,25 & 0,70 & 1,16 & 0,66 \\
\hline 28 & Fabricação de Açúcar & 1,26 & 0,71 & 1,21 & 0,69 \\
\hline 29 & Fabricação de Óleos Vegetais & 1,30 & 0,82 & 1,24 & 0,83 \\
\hline 30 & Outros Produtos Alimentares & 1,18 & 0,81 & 1,16 & 0,80 \\
\hline 31 & Indústrias Diversas & 0,98 & 0,69 & 0,98 & 0,63 \\
\hline 32 & Serviços Industriais de Utilidade Pública & 0,82 & 1,43 & 0,84 & 1,68 \\
\hline 33 & Construção Civil & 0,84 & 0,66 & 0,87 & 0,65 \\
\hline 34 & Comércio & 0,80 & 1,70 & 0,92 & 2,07 \\
\hline 35 & Supermercados & 1,32 & 0,52 & 1,36 & 0,52 \\
\hline 36 & Transportes & 0,85 & 1,42 & 0,99 & 1,40 \\
\hline 37 & Comunicações & 0,64 & 0,71 & 0,66 & 0,96 \\
\hline 38 & Instituições Financeiras & 0,70 & 1,00 & 0,74 & 1,07 \\
\hline 39 & Serviços Prestados às Famílias & 0,84 & 0,82 & 0,89 & 0,72 \\
\hline 40 & Serviços Prestados às Empresas & 0,73 & 1,13 & 0,75 & 1,34 \\
\hline 41 & Aluguel de Imóveis & 0,56 & 0,75 & 0,55 & 0,73 \\
\hline 42 & Administração Pública & 0,76 & 0,86 & 0,73 & 0,77 \\
\hline 43 & Serviços Privados não-mercantis & 0,58 & 0,52 & 0,57 & 0,51 \\
\hline
\end{tabular}




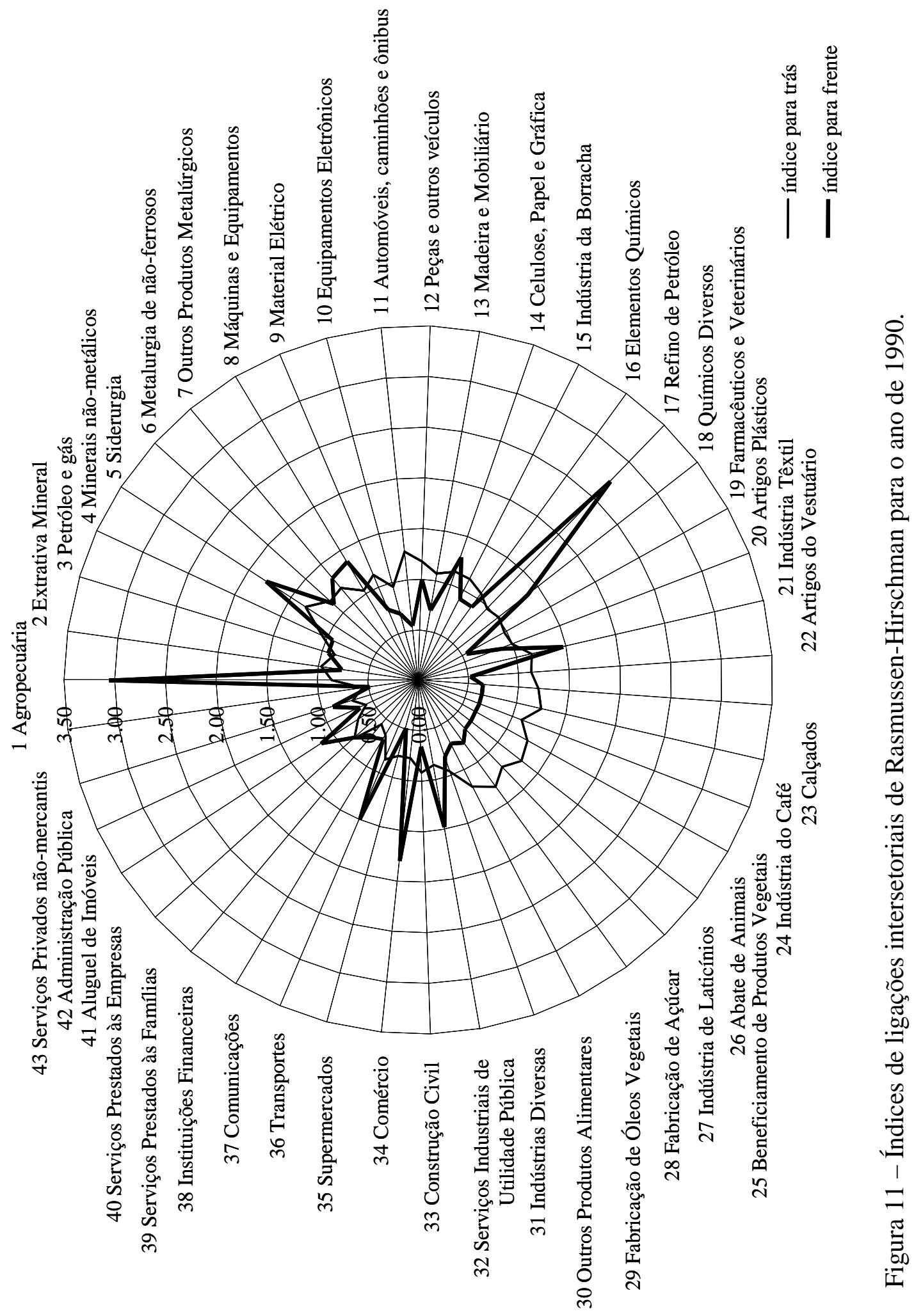




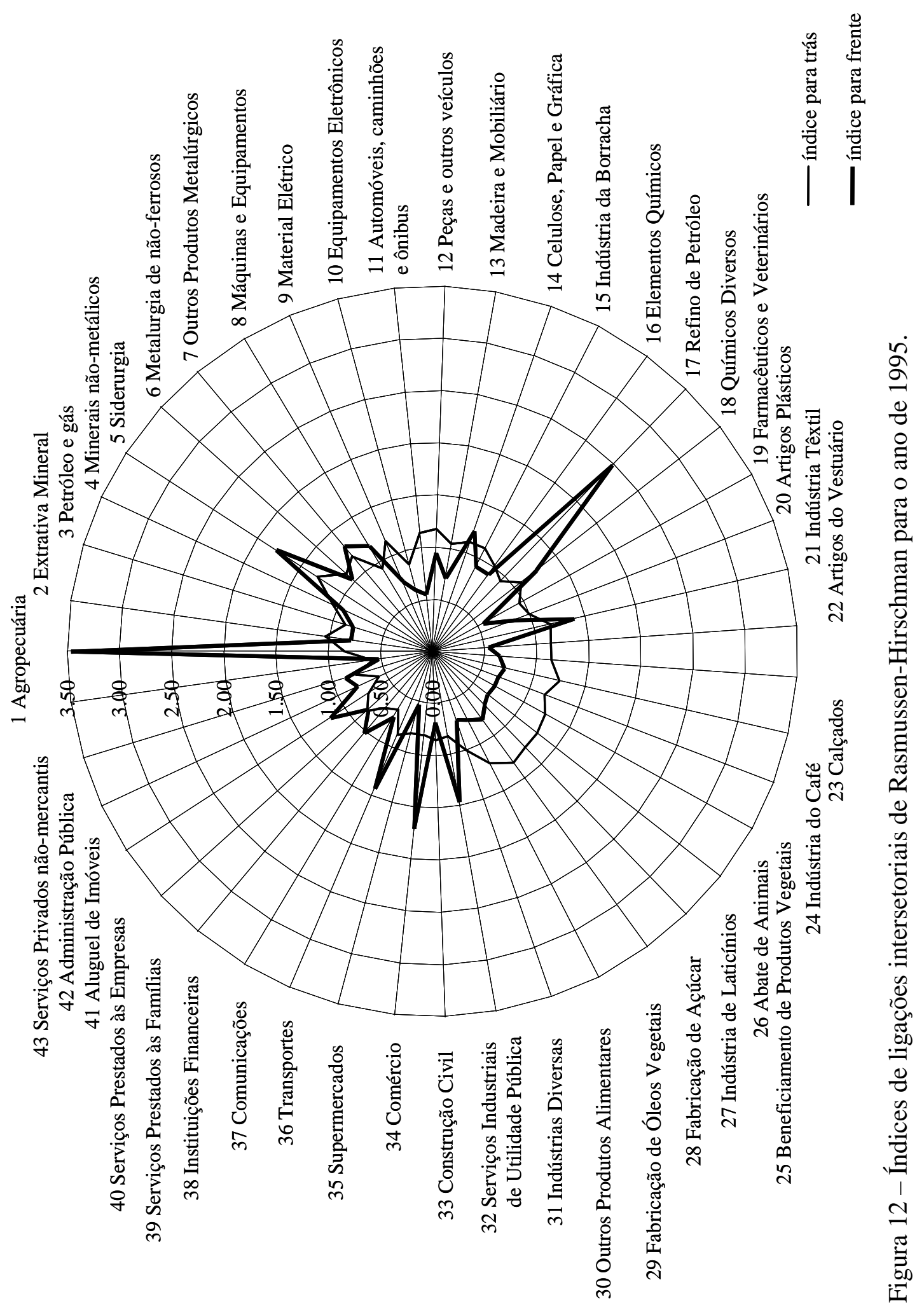




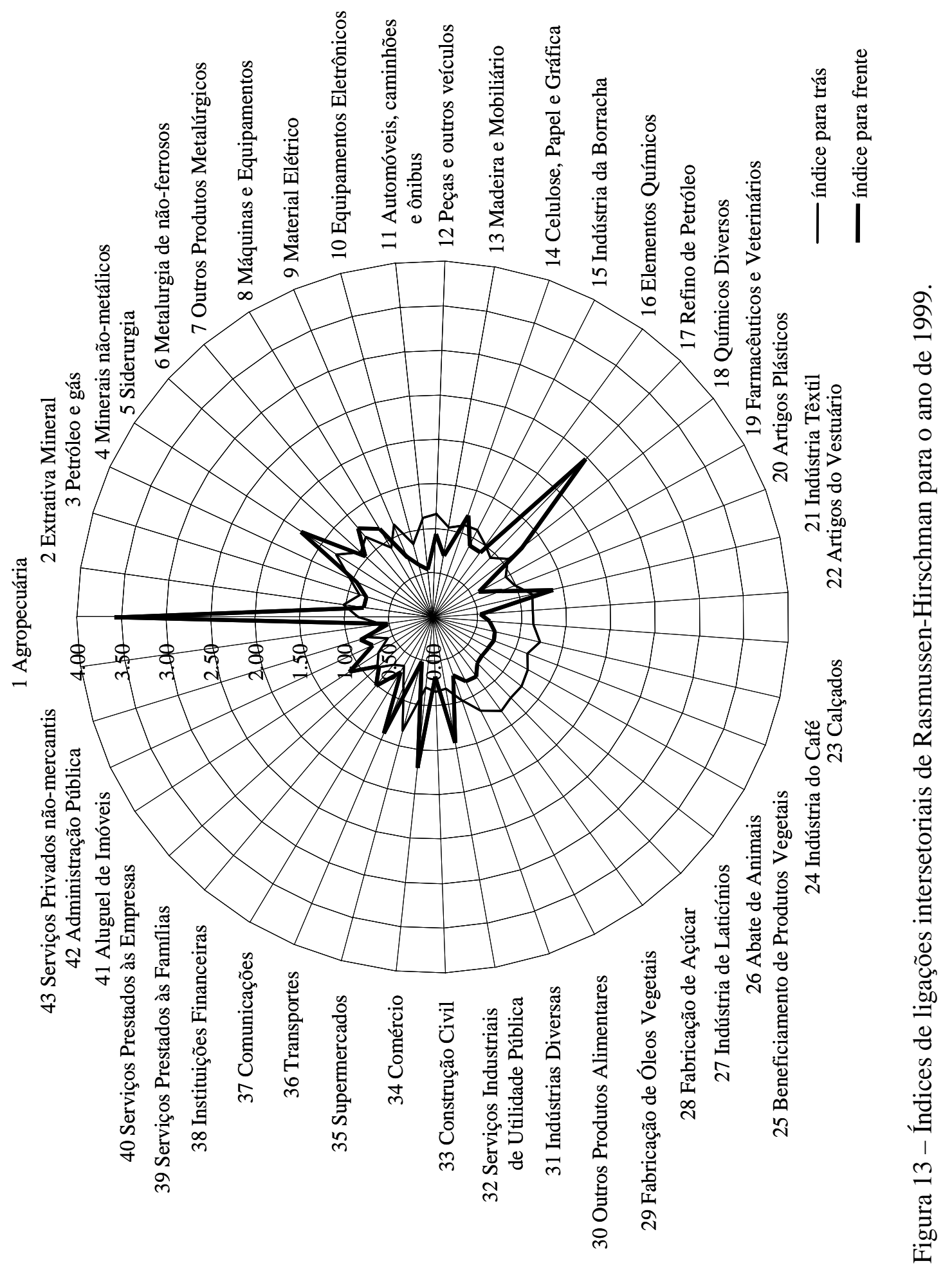




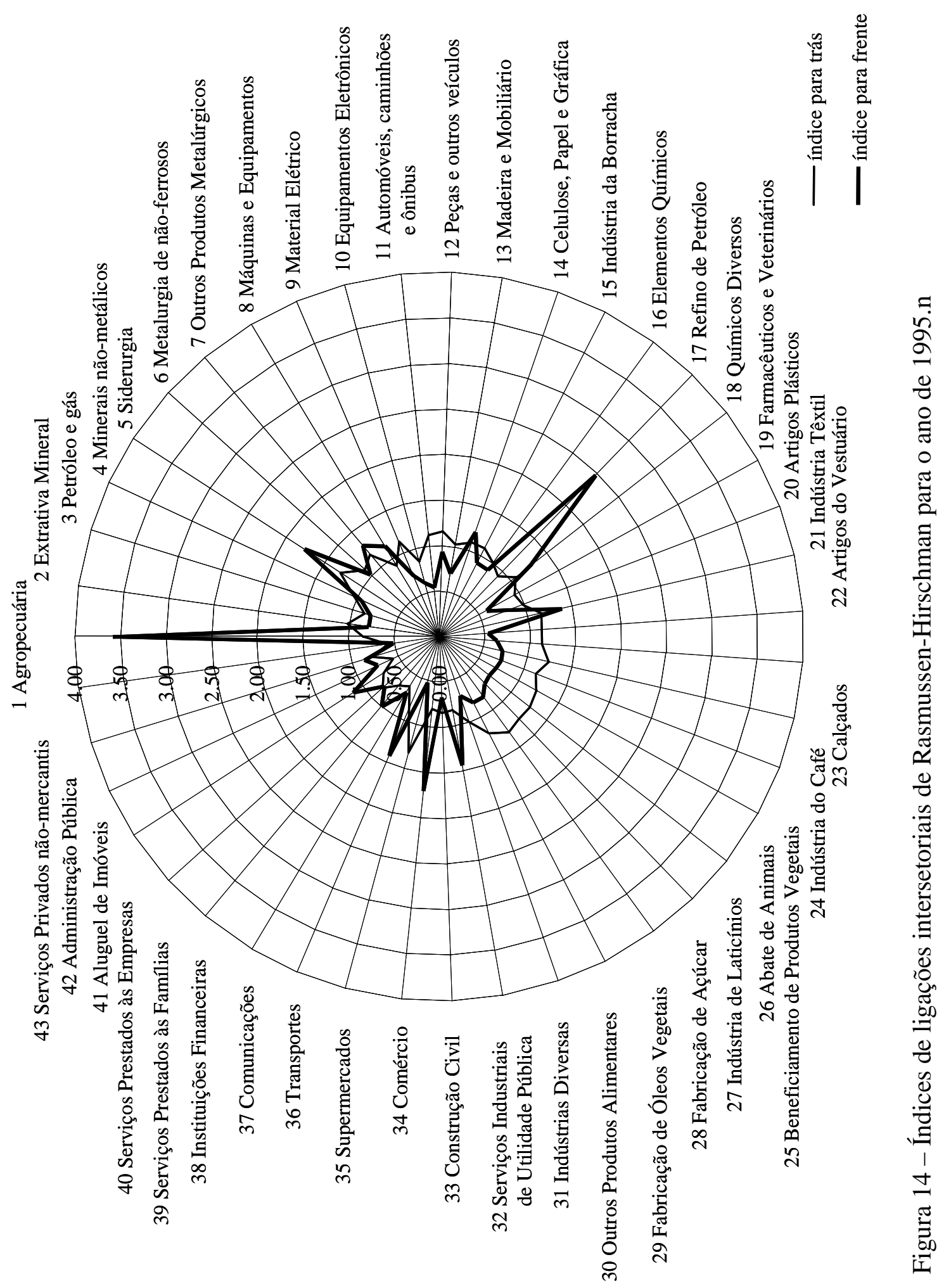




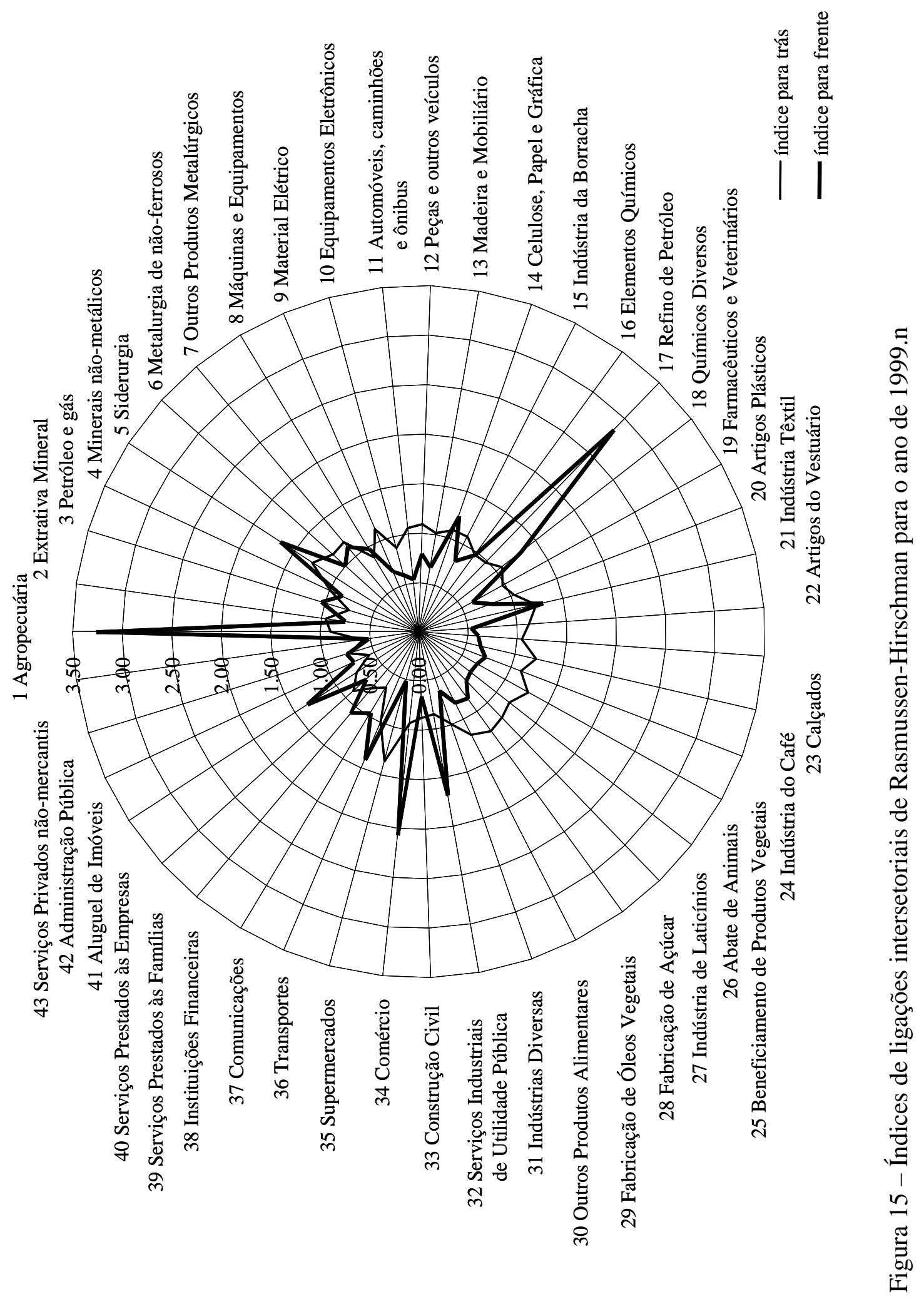


Apesar dos índices de Rasmussen-Hirschman serem amplamente utilizados na análise de setores-chave, não levam em conta a produção total da indústria. Os índices puros normalizados permitem analisar as ligações intersetoriais dentro do sistema econômico com a vantagem de considerar conjuntamente o valor total destas ligações, assim como foi detalhado no capítulo teórico.

Podem ser identificados na Tabela 51, a qual resume os resultados para a metodologia tradicional, cinco setores que se destacam em valores de índices para trás: 42-Administração pública, 33-Construção civil, 39-Serviços prestados às famílias, 34Comércio e 30-Outros produtos alimentares. Em relação aos índices de ligações para frente, têm-se: 1-Agropecuária, 17-Refino de petróleo, 34-Comércio, 40-Serviços prestados às empresas e 36-Transportes. Os resultados obtidos não incorporam o efeito da aquisição das mercadorias comercializadas pelo setor supermercadista em seus índices de ligações intersetoriais, os valores se referem somente à seus custos operacionais básicos.

Os resultados obtidos para a nova proposta metodológica resumidos na Tabela 52 se aproximam dos números da Tabela 51, porém, o setor 35-Supermercados é o que apresenta o maior valor para o índice de ligações para trás no ano de 1999n. Além disso, este aumentou no período 1995n/99n passando de 6,18 para 6,35. Este crescimento deixa clara a grande importância do setor como comprador de bens e serviços da economia. $\mathrm{O}$ índice de ligações intersetoriais para frente do setor supermercadista é relativamente pequeno, pois como foi analisado anteriormente este vende seus produtos diretamente ao consumidor final.

As Figuras 16 e 17 ilustram os índices de ligações intersetoriais puros normalizados totais. Nota-se que a principal diferença entre os valores da metodologia tradicional e a nova proposta metodológica é o valor calculado para o 35-Setor Supermercados, que na Figura 17 aparece como um setor-chave para a economia no período analisado (1995/99). Além disso, houve um aumento do valor calculado neste período, indicando importância crescente do setor supermercadista dentro da cadeia de comercialização dos produtos vendidos diretamente para a população. 
Tabela 51. Índices de ligações intersetoriais puros normalizados e classificação pelo valor total para os anos de 1995 e 1999, desagregação do setor supermercados pela metodologia tradicional.

\begin{tabular}{|c|c|c|c|c|c|c|c|c|c|c|c|c|c|}
\hline \multirow{2}{*}{\multicolumn{2}{|c|}{ Setor }} & \multicolumn{4}{|c|}{1990} & \multicolumn{4}{|c|}{1995} & \multicolumn{4}{|c|}{1999} \\
\hline & & o & trás & frente & total & o & trás & frente & total & o & trás & frente & total \\
\hline 1 & Agropecuária & 3 & 1,55 & 4,09 & 2,82 & 2 & 1,40 & 5,15 & 3,27 & 2 & 1,81 & 4,75 & 3,27 \\
\hline 2 & Extrativa Mineral & 39 & 0,27 & 0,39 & 0,33 & 37 & 0,24 & 0,35 & 0,30 & 39 & 0,24 & 0,30 & 0,27 \\
\hline 3 & Petróleo e gás & 33 & 0,04 & 0,81 & 0,42 & 41 & 0,00 & 0,47 & 0,23 & 29 & 0,00 & 0,96 & 0,48 \\
\hline 4 & Minerais não-metálicos & 23 & 0,14 & 1,54 & 0,84 & 21 & 0,12 & 1,43 & 0,77 & 22 & 0,11 & 1,35 & 0,73 \\
\hline 5 & Siderurgia & 12 & 0,43 & 1,71 & 1,07 & 14 & 0,36 & 1,72 & 1,04 & 14 & 0,31 & 1,54 & 0,92 \\
\hline 6 & Metalurgia de não-ferrosos & 29 & 0,20 & 0,79 & 0,49 & 31 & 0,21 & 0,65 & 0,43 & 32 & 0,26 & 0,60 & 0,43 \\
\hline 7 & Outros Produtos Metalúrgicos & 14 & 0,31 & 1,77 & 1,04 & 13 & 0,35 & 1,73 & 1,04 & 16 & 0,34 & 1,46 & 0,90 \\
\hline 8 & Máquinas e Equipamentos & 9 & 1,05 & 1,34 & 1,19 & 17 & 0,88 & 1,12 & 1,00 & 18 & 0,81 & 0,82 & 0,82 \\
\hline 9 & Material Elétrico & 24 & 0,71 & 0,71 & 0,71 & 24 & 0,80 & 0,57 & 0,68 & 27 & 0,75 & 0,37 & 0,56 \\
\hline 10 & Equipamentos Eletrônicos & 30 & 0,79 & 0,16 & 0,47 & 30 & 0,80 & 0,10 & 0,45 & 40 & 0,42 & 0,08 & 0,25 \\
\hline 11 & Automóveis, caminhões e & 13 & 1,97 & 0,10 & 1,04 & 11 & 2,29 & 0,06 & 1,18 & 20 & 1,46 & 0,05 & 0,75 \\
\hline 12 & Peças e outros veículos & 20 & 0,62 & 1,21 & 0,92 & 18 & 0,65 & 1,25 & 0,95 & 21 & 0,71 & 0,78 & 0,74 \\
\hline 13 & Madeira e Mobiliário & 26 & 0,73 & 0,49 & 0,61 & 28 & 0,63 & 0,45 & 0,54 & 30 & 0,60 & 0,36 & 0,48 \\
\hline 14 & Celulose, Papel e Gráfica & 18 & 0,42 & 1,47 & 0,94 & 19 & 0,39 & 1,47 & 0,93 & 15 & 0,39 & 1,44 & 0,91 \\
\hline 15 & Indústria da Borracha & 38 & 0,05 & 0,62 & 0,34 & 35 & 0,06 & 0,61 & 0,33 & 37 & 0,08 & 0,50 & 0,29 \\
\hline 16 & Elementos Químicos & 25 & 0,44 & 0,81 & 0,62 & 27 & 0,40 & 0,75 & 0,58 & 26 & 0,17 & 0,99 & 0,58 \\
\hline 17 & Refino & 6 & 0,33 & 4,24 & 2,28 & 6 & 0,25 & 3,65 & 1,95 & 6 & 0,21 & 4,76 & 2,48 \\
\hline 18 & Quími & 22 & 0,11 & 1,62 & 0,86 & 20 & 0,16 & 1,41 & 0,78 & 17 & 0,15 & 1,60 & 0,87 \\
\hline 19 & Farma & 31 & 0,77 & 0,18 & 0,47 & 29 & 0,80 & 0,11 & 0,45 & 28 & 0,85 & 0,19 & 0,52 \\
\hline 20 & Artig & 32 & 0,08 & 0,85 & 0,47 & 32 & 0,12 & 0,72 & 0,42 & 33 & 0,07 & 0,67 & 0,37 \\
\hline 21 & Indú & 15 & 0,45 & 1,58 & 1,01 & 22 & 0,34 & 1,13 & 0,73 & 24 & 0,35 & 0,89 & 0,62 \\
\hline 22 & Arti & 21 & 1,74 & 0,05 & 0,90 & 26 & 1,13 & 0,02 & 0,58 & 31 & 0,85 & 0,02 & 0,43 \\
\hline 23 & $\mathrm{Cal}$ & 35 & 0,71 & 0,07 & 0,39 & 39 & 0,46 & 0,04 & 0,25 & 41 & 0,35 & 0,03 & 0,19 \\
\hline 24 & Indús & 41 & 0,38 & 0,04 & 0,21 & 40 & 0,41 & 0,07 & 0,24 & 34 & 0,67 & 0,05 & 0,36 \\
\hline 25 & $\begin{array}{l}\text { Beneficiamento de Produtos } \\
\text { Vegetais }\end{array}$ & 19 & 1,44 & 0,40 & 0,92 & 12 & $1,0 J$ & 0,47 & 1,05 & 13 & 1,60 & & 1,02 \\
\hline 26 & Abate & 16 & 1,74 & 0,27 & 1,01 & 15 & 1,73 & 0,27 & 1,00 & 12 & 2,07 & 0,22 & 1,1 \\
\hline 27 & Indú: & 34 & 0,68 & 0,10 & 0,39 & 33 & 0,68 & 0,12 & 0,40 & 36 & 0,51 & 0,09 & 0,30 \\
\hline 28 & Fabr & 40 & 0,30 & 0,22 & 0,26 & 38 & 0,35 & 0,22 & 0,28 & 38 & 0,37 & 0,19 & 0,28 \\
\hline 29 & Fabrica & 28 & 0,65 & 0,36 & 0,51 & 25 & 0,81 & 0,42 & 0,61 & 25 & 0,72 & 0,46 & 0,59 \\
\hline 30 & Outr & 8 & 1,89 & 0,62 & 1,26 & 8 & 2,12 & 0,77 & & 9 & 2,00 & 0,76 & 1,38 \\
\hline 31 & Indús & 36 & 0,20 & 0,54 & 0,37 & 36 & 0,27 & 0,40 & 0,33 & 35 & 0,32 & 0,31 & 0,31 \\
\hline 32 & $\begin{array}{l}\text { Serviços Industriais de Utilidade } \\
\text { Pública }\end{array}$ & 11 & 0,38 & 1,79 & 1,08 & 16 & 0,27 & 1,76 & 1,00 & & 0,31 & & 1,21 \\
\hline 33 & Construção Civil & 1 & 6,55 & 0,54 & 3,55 & 3 & 5,31 & 0,62 & 2,97 & 3 & 5,76 & 0,58 & 3,1 \\
\hline 34 & Comér & & 2,76 & 3,32 & 3,04 & 4 & 2,48 & 3,34 & 2,91 & & 3,38 & 3,57 & 3,47 \\
\hline 35 & Super & 42 & 0,25 & 0,02 & 0,13 & 42 & 0,37 & 0,02 & 0,20 & 42 & 0,33 & 0,03 & 0,18 \\
\hline 36 & Trans & 7 & 1,36 & 2,12 & 1,74 & 7 & 1,27 & 2,04 & 1,66 & 7 & 1,64 & 1,91 & 1,78 \\
\hline 37 & Comu & 37 & 0,10 & 0,57 & 0,34 & 34 & 0,12 & 0,65 & 0,39 & 19 & 0,33 & 1,20 & 0,76 \\
\hline 38 & Institu & 17 & 1,48 & 0,51 & 1,00 & 10 & 1,47 & 1,04 & 1,26 & 10 & 1,47 & 1,17 & 1,32 \\
\hline 39 & Serviços I & & 3,69 & 1,41 & 2,55 & 5 & 3,77 & 1,57 & 2,67 & 5 & 3,85 & 1,18 & 2,52 \\
\hline 40 & Serviços Prestados às Empresas & 10 & 0,08 & 2,24 & 1,16 & 9 & 0,12 & 2,68 & 1,40 & 8 & 0,21 & 2,96 & 1,58 \\
\hline 41 & Alugue & 27 & 0,55 & 0,50 & 0,52 & 23 & 0,53 & 0,86 & 0,69 & 23 & 0,56 & 0,72 & 0,64 \\
\hline 42 & Admi & & 4,54 & 0,82 & 2,68 & 1 & 6,37 & 0,75 & 3,57 & 4 & 5,51 & 0,55 & 3,03 \\
\hline 43 & Serviços Privados não-mercantis & 43 & 0,10 & 0,00 & 0,05 & 43 & 0,10 & 0,00 & 0,05 & 43 & 0,10 & 0,00 & 0,05 \\
\hline
\end{tabular}


Tabela 52. Índices de ligações intersetoriais puros normalizados e classificação pelo valor total para os anos de 1995 e 1999, desagregação do setor supermercados pela nova proposta metodológica.

\begin{tabular}{|c|c|c|c|c|c|c|c|c|c|}
\hline \multirow{2}{*}{\multicolumn{2}{|c|}{ Setor }} & \multicolumn{4}{|c|}{$1995 n$} & \multicolumn{4}{|c|}{$1999 n$} \\
\hline & & ordem & trás & frente & total & ordem & trás & frente & total \\
\hline 1 & Agropecuária & 2 & 1,16 & 5,16 & 3,16 & 2 & 1,59 & 4,82 & 3,20 \\
\hline 2 & Extrativa Mineral & 38 & 0,23 & 0,32 & 0,27 & 41 & 0,23 & 0,28 & 0,26 \\
\hline 3 & Petróleo e gás & 42 & 0,00 & 0,44 & 0,22 & 31 & 0,00 & 0,89 & 0,45 \\
\hline 4 & Minerais não-metálicos & 22 & 0,11 & 1,33 & 0,72 & 23 & 0,10 & 1,27 & 0,68 \\
\hline 5 & Siderurgia & 14 & 0,33 & 1,60 & 0,96 & 16 & 0,30 & 1,43 & 0,86 \\
\hline 6 & Metalurgia de não-ferrosos & 32 & 0,19 & 0,61 & 0,40 & 33 & 0,25 & 0,57 & 0,41 \\
\hline 7 & Outros Produtos Metalúrgicos & 13 & 0,30 & 1,63 & 0,96 & 17 & 0,30 & 1,38 & 0,84 \\
\hline 8 & Máquinas e Equipamentos & 16 & 0,81 & 1,04 & 0,93 & 19 & 0,79 & 0,76 & 0,78 \\
\hline 9 & Material Elétrico & 25 & 0,67 & 0,60 & 0,63 & 28 & 0,66 & 0,41 & 0,54 \\
\hline 10 & Equipamentos Eletrônicos & 31 & 0,69 & 0,20 & 0,44 & 40 & 0,39 & 0,13 & 0,26 \\
\hline 11 & Automóveis, caminhões e ônibus & 12 & 2,13 & 0,06 & 1,09 & 20 & 1,44 & 0,05 & 0,74 \\
\hline 12 & Peças e outros veículos & 20 & 0,60 & 1,16 & 0,88 & 22 & 0,70 & 0,72 & 0,71 \\
\hline 13 & Madeira e Mobiliário & 29 & 0,58 & 0,42 & 0,50 & 30 & 0,59 & 0,33 & 0,47 \\
\hline 14 & Celulose, Papel e Gráfica & 19 & 0,27 & 1,51 & 0,89 & 15 & 0,28 & 1,51 & 0,89 \\
\hline 15 & Indústria da Borracha & 37 & 0,06 & 0,56 & 0,31 & 38 & 0,07 & 0,46 & 0,27 \\
\hline 16 & Elementos Químicos & 27 & 0,37 & 0,70 & 0,53 & 27 & 0,16 & 0,92 & 0,54 \\
\hline 17 & Refino de Petróleo & 7 & 0,23 & 3,39 & 1,81 & 6 & 0,20 & 4,40 & 2,29 \\
\hline 18 & Químicos Diversos & 21 & 0,14 & 1,32 & 0,73 & 18 & 0,13 & 1,50 & 0,81 \\
\hline 19 & Farmacêuticos e Veterinários & 30 & 0,48 & 0,42 & 0,45 & 29 & 0,63 & 0,43 & 0,53 \\
\hline 20 & Artigos Plásticos & 33 & 0,10 & 0,68 & 0,39 & 35 & 0,06 & 0,64 & 0,35 \\
\hline 21 & Indústria Têxtil & 23 & 0,30 & 1,07 & 0,69 & 25 & 0,34 & 0,85 & 0,59 \\
\hline 22 & Artigos do Vestuário & 28 & 1,00 & 0,06 & 0,53 & 32 & 0,77 & 0,06 & 0,42 \\
\hline 23 & Calçados & 40 & 0,42 & 0,05 & 0,23 & 42 & 0,33 & 0,04 & 0,19 \\
\hline 24 & Indústria do Café & 41 & 0,32 & 0,14 & 0,23 & 34 & 0,57 & 0,12 & 0,35 \\
\hline 25 & Beneficiamento de Produtos Vegetais & 15 & 1,10 & 0,80 & 0,95 & 14 & 1,13 & 0,79 & 0,96 \\
\hline 26 & Abate de Animais & 18 & 1,29 & 0,54 & 0,91 & 13 & 1,64 & 0,49 & 1,07 \\
\hline 27 & Indústria de Laticínios & 34 & 0,35 & 0,41 & 0,38 & 37 & 0,22 & 0,38 & 0,30 \\
\hline 28 & Fabricação de Açúcar & 39 & 0,28 & 0,24 & 0,26 & 39 & 0,31 & 0,23 & 0,27 \\
\hline 29 & Fabricação de Óleos Vegetais & 26 & 0,60 & 0,53 & 0,57 & 26 & 0,57 & 0,56 & 0,57 \\
\hline 30 & Outros Produtos Alimentares & 9 & 1,32 & 1,28 & 1,30 & 10 & 1,28 & 1,27 & 1,28 \\
\hline 31 & Indústrias Diversas & 36 & 0,22 & 0,40 & 0,31 & 36 & 0,28 & 0,32 & 0,30 \\
\hline 32 & Serviços Industriais de Utilidade Pública & 17 & 0,22 & 1,63 & 0,93 & 12 & 0,30 & 1,96 & 1,13 \\
\hline 33 & Construção Civil & 4 & 4,93 & 0,57 & 2,76 & 3 & 5,60 & 0,54 & 3,08 \\
\hline 34 & Comércio & 5 & 2,29 & 3,11 & 2,70 & 7 & 1,16 & 3,37 & 2,26 \\
\hline 35 & Supermercados & 3 & 6,18 & 0,02 & 3,11 & 1 & 6,35 & 0,02 & 3,20 \\
\hline 36 & Transportes & 8 & 1,14 & 1,97 & 1,55 & 8 & 1,54 & 1,84 & 1,69 \\
\hline 37 & Comunicações & 35 & 0,11 & 0,60 & 0,36 & 21 & 0,32 & 1,11 & 0,72 \\
\hline 38 & Instituições Financeiras & 11 & 1,37 & 0,96 & 1,17 & 11 & 1,41 & 1,08 & 1,25 \\
\hline 39 & Serviços Prestados às Famílias & 6 & 3,51 & 1,45 & 2,48 & 5 & 3,79 & 1,09 & 2,44 \\
\hline 40 & Serviços Prestados às Empresas & 10 & 0,11 & 2,49 & 1,30 & 9 & 0,20 & 2,75 & 1,47 \\
\hline 41 & Aluguel de Imóveis & 24 & 0,49 & 0,79 & 0,64 & 24 & 0,53 & 0,66 & 0,60 \\
\hline 42 & Administração Pública & 1 & 5,89 & 0,74 & 3,32 & 4 & 5,40 & 0,53 & 2,98 \\
\hline 43 & Serviços Privados não-mercantis & 43 & 0,10 & 0,00 & 0,05 & 43 & 0,09 & 0,00 & 0,05 \\
\hline
\end{tabular}




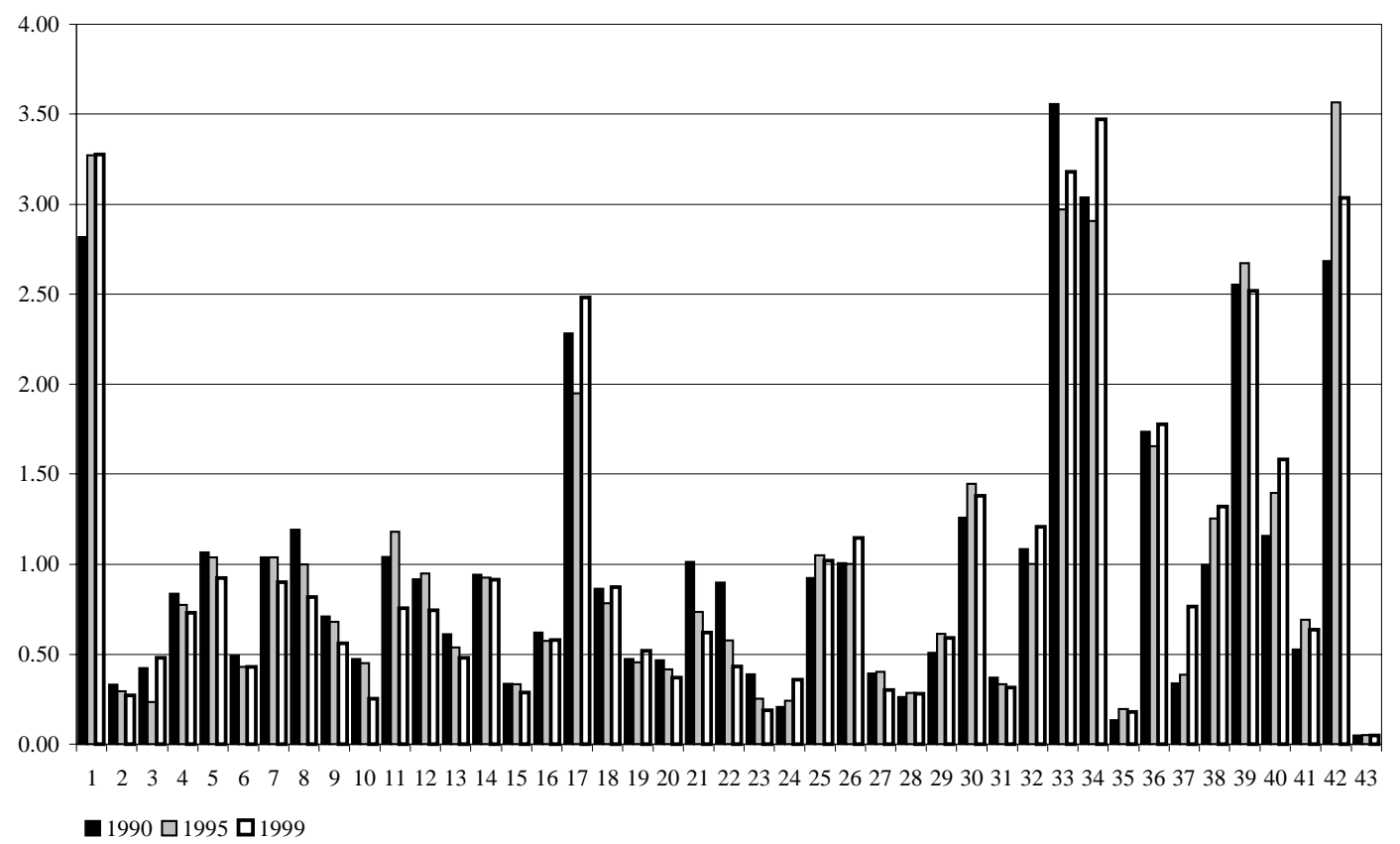

Figura 16 - Índices de ligações intersetoriais puros normalizados totais dos anos de 1990, 1995 e 1999 (metodologia tradicional).

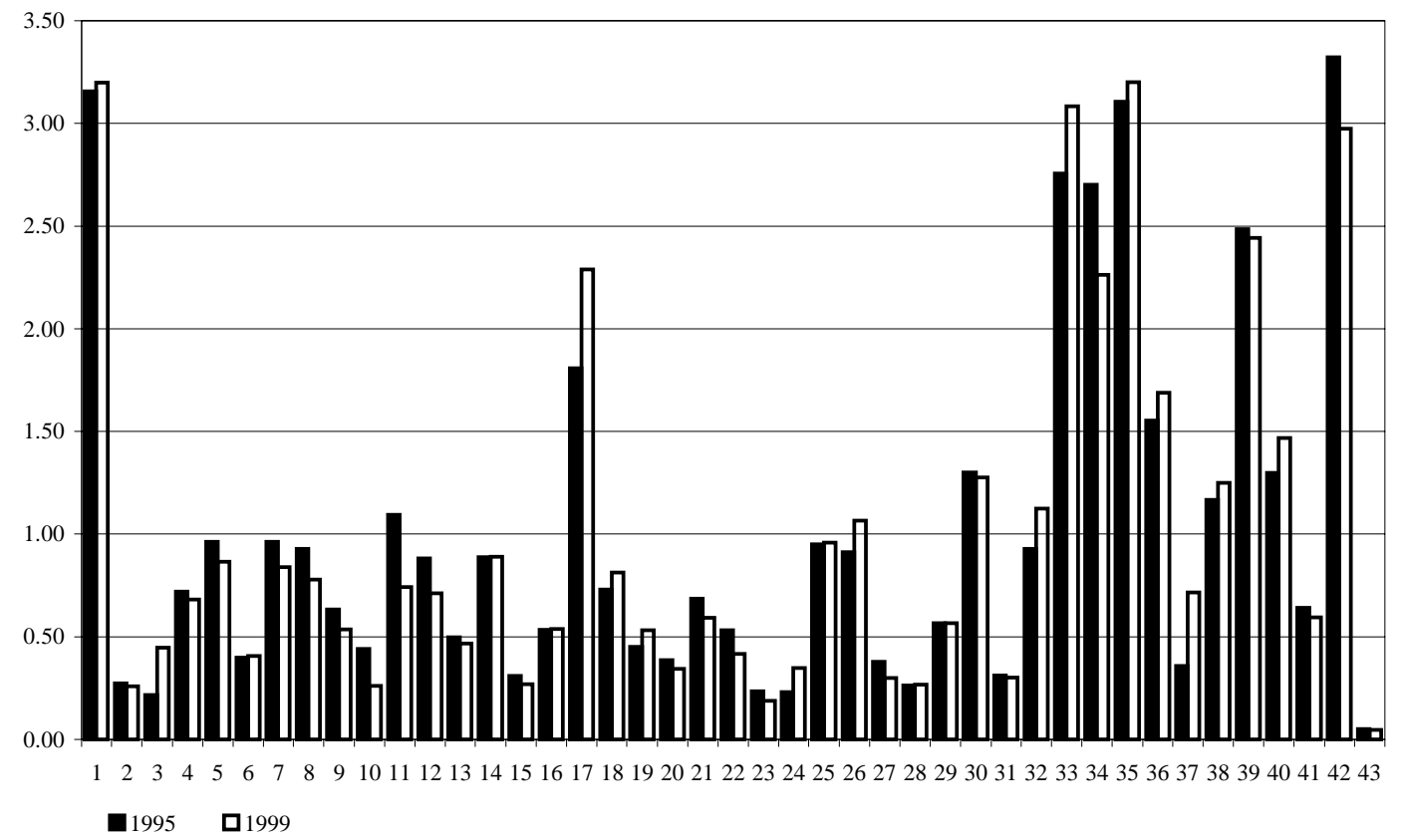

Figura 17 - Índices de ligações intersetoriais puros normalizados totais dos anos de 1995 e 1999, setor 35-Supermercados desagregado pela nova proposta metodológica. 
O campo de influência permite determinar quais setores são elos importantes em ligações intersetoriais para frente e para trás, complementando a análise dos índices de ligações intersetoriais. As Figuras 18, 19 e 20 resumem os resultados para as matrizes nacionais de 1990/95/99, que possuem o setor 35-Supermercados desagregado pela metodologia tradicional. As Figuras 21 e 22 resumem os resultados obtidos pela nova proposta metodológica. As Figuras foram elaboradas considerando-se as 100 primeiras combinações (ou relações) de setores.

A análise dos resultados indica que existem setores com grande influência sobre a produção de seus setores fornecedores, tais como 5-Siderurgia, 17-Refino de petróleo, 21-Indústria têxtil, 26-Abate de animais e 27-Indústria de laticínios. Por outro lado, os setores de maior influência sobre seus compradores são 1-Agropecuária, 5-Siderurgia, 17-Refino de petróleo, 21-Indústria têxtil e 32-Serviços industriais de utilidade pública.

Os resultados obtidos para as duas metodologias mostram que o setor supermercadista (setor 35) surge como importante comprador para o setor 1Agropecuária. Porém, para os outros setores da economia, os 35-Supermercados não apresentam importante influência.

A abordagem do campo de influência indica pequena relevância do setor supermercadista para as outras indústrias diretamente relacionadas. Por outro lado, os resultados obtidos para os índices de ligações intersetoriais e os multiplicadores de produção mostram que o setor 35-Supermercados desagregado pela nova proposta metodológica tem importância relativamente grande para a economia. A análise conjunta dos indicadores econômicos leva a crer que a principal influência do setor supermercadista sobre a economia é determinada por efeitos indiretos e, principalmente, induzidos. 
Setores compradores

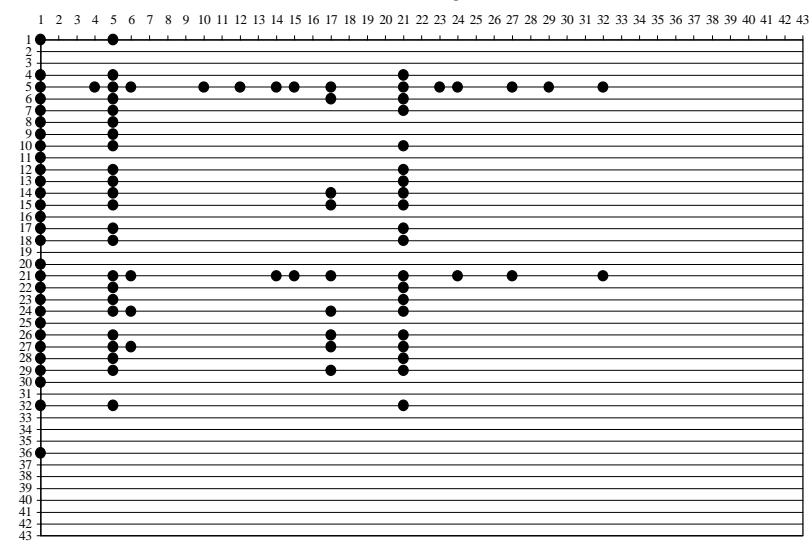

Figura 18 - Campo de influência dos setores para o ano de 1990.

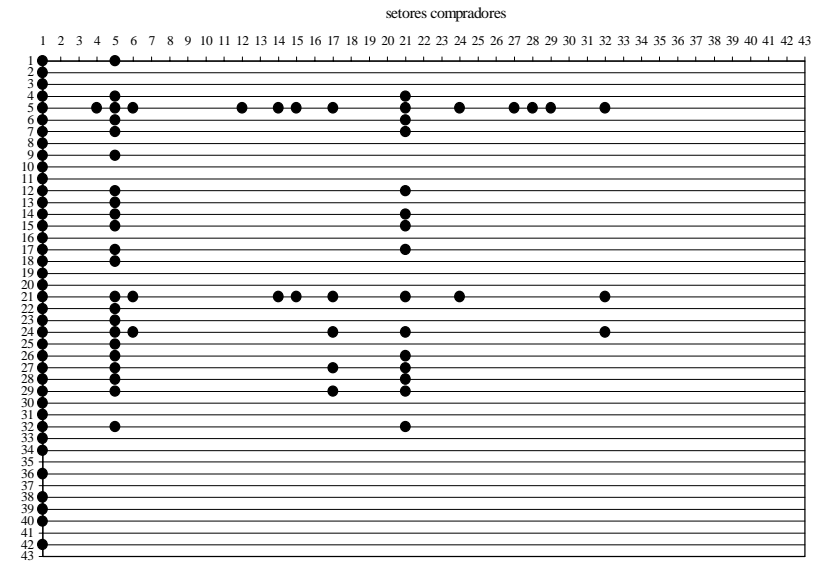

Figura 19 - Campo de influência dos setores para o ano de 1995.

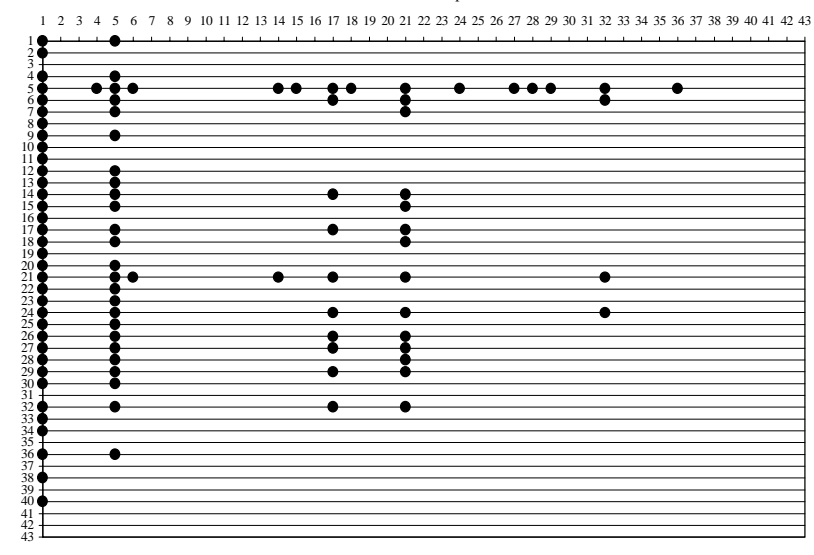

Figura 20 - Campo de influência dos setores para o ano de 1999. 
setores compradores

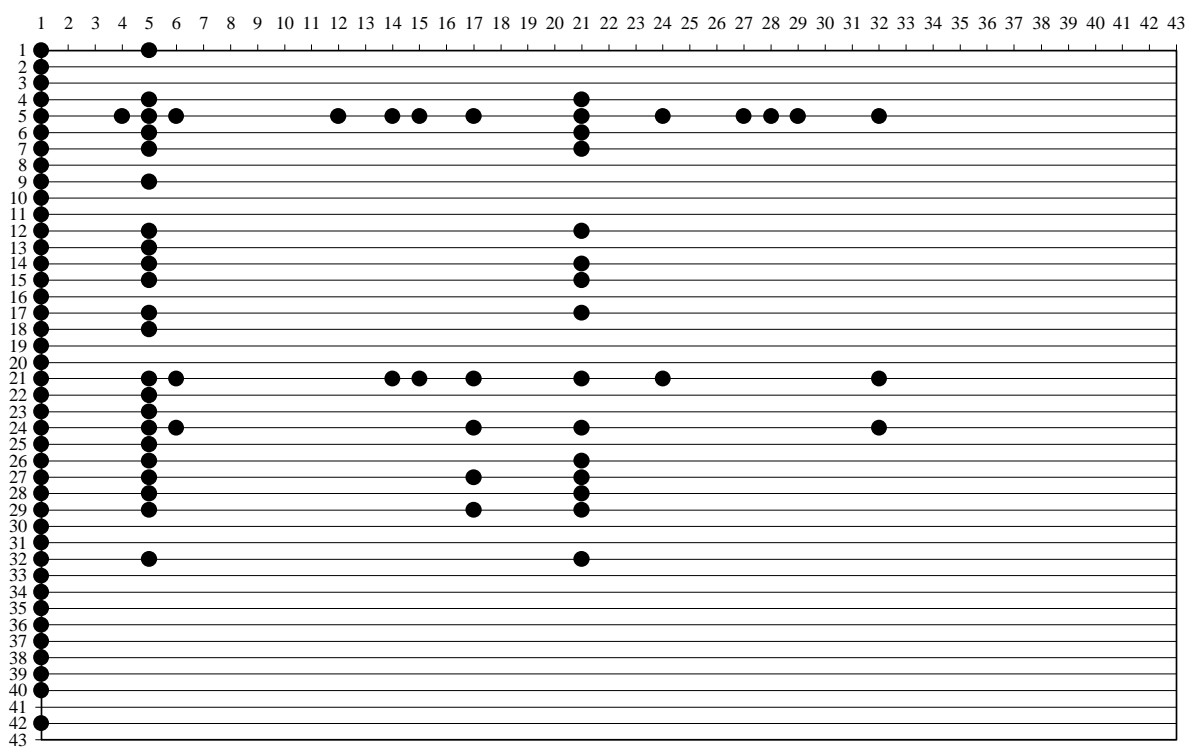

Figura 21 - Campo de influência dos setores para o ano de 1995n.

setores compradores

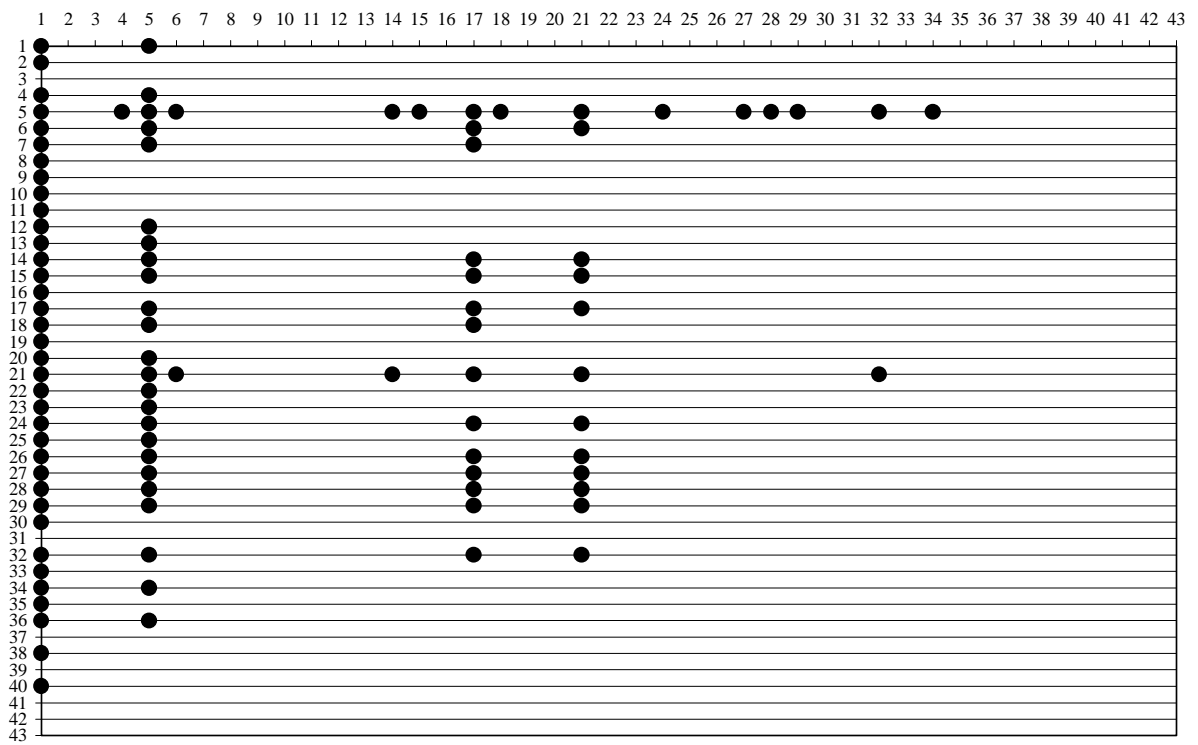

Figura 22 - Campo de influência dos setores para o ano de 1999n. 
O campo de influência dos setores determinado com a endogeneização do componente Consumo das famílias é ilustrado pelas Figuras 23 e 24. Os cálculos foram feitos utilizando a matriz de insumo-produto do Brasil de 1999 com o setor 35Supermercados desagregado pela nova proposta metodológica. A Figura 23 possui as cem principais combinações de setores excluindo-se os resultados para o novo setor 44Consumo das famílias e a Figura 24 apresenta as combinações sem a exclusão do novo setor. Pode-se notar, comparando-se as Figuras 22 e 23, que o efeito provocado pelo novo setor aumenta a importância dos setores de comércio e serviços levando em consideração o efeito induzido.

A importância do componente da demanda final incorporado como o novo setor 44-Consumo das famílias é facilmente observada comparando-se as Figuras 23 e 24, a nova indústria é a que possui maior número de combinações. O setor 35-Supermercados possui maior influência sobre os setores 1-Agropecuária e 34-Comércio.

Os setores que têm maior destaque, considerando o efeito do Consumo das famílias sobre a economia, são: 1-Agropecuária, 17-Refino de petróleo, 34-Comércio, 41-Aluguel de imóveis e 43-Serviços privados não-mercantis, além obviamente os próprio novo setor 44-Consumo das famílias, que se torna o principal. 
Setores compradores

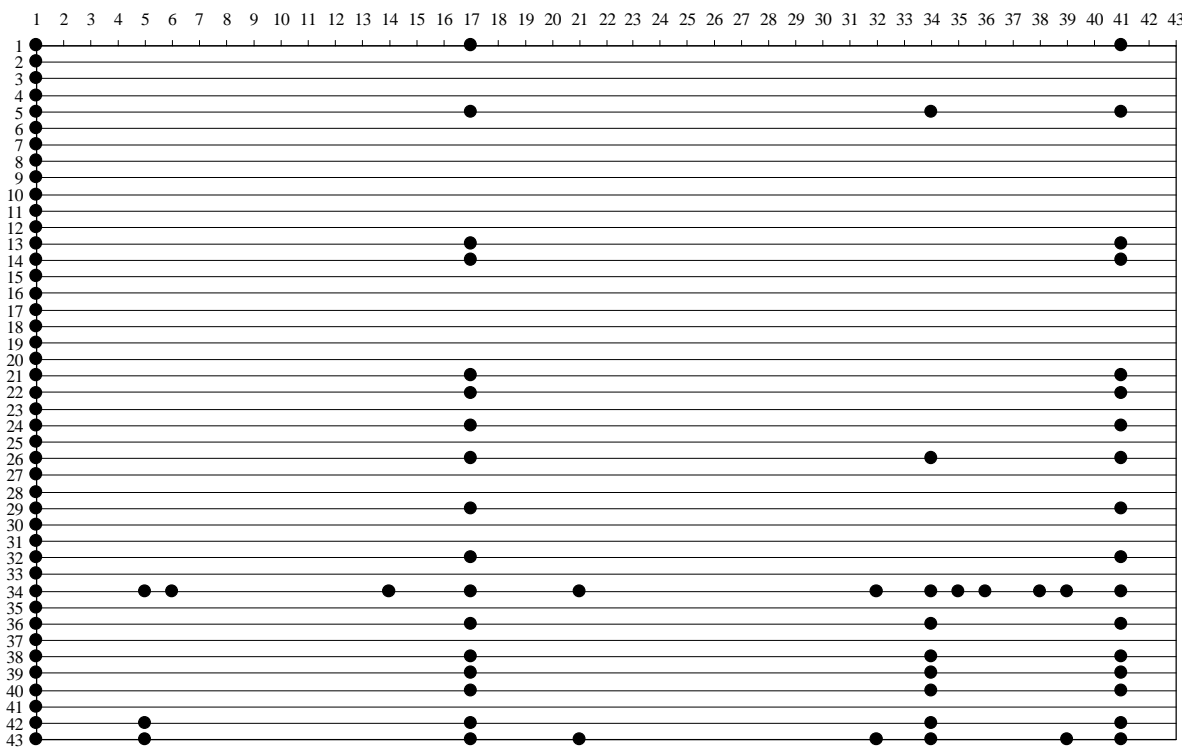

Figura 23 - Campo de influência dos setores para o ano de 1999n com endogeneização do componente Consumo das famílias (com exclusão do novo setor).

Setores compradores

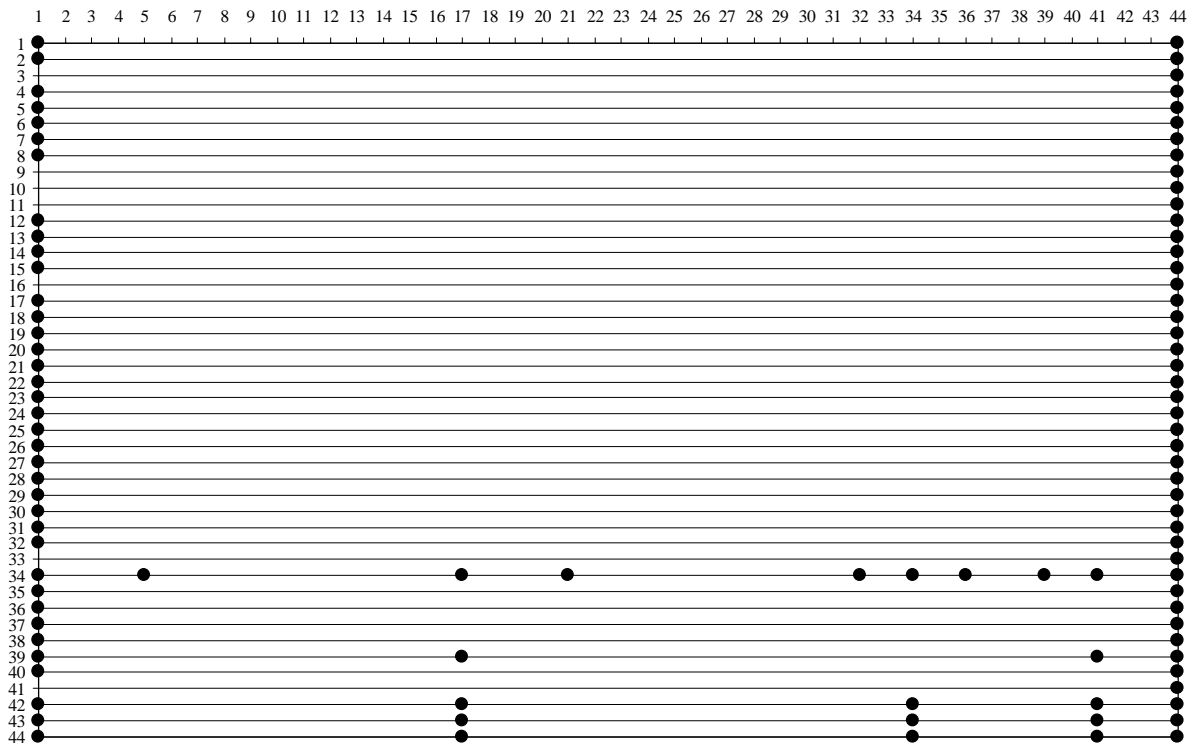

Figura 24 - Campo de influência dos setores para o ano de 1999n com endogeneização do componente Consumo das famílias (sem exclusão do novo setor). 
Objetivando comparar os resultados da geração de empregos (GE) e de renda (GR), multiplicador de produção tipo II (MP) e índices de ligações de RasmussenHirschman, puros normalizados (GHS) e do campo de influência, foi elaborado o quadro 4. Neste estão relacionados os setores-chave determinados para cada indicador econômico para o ano de 1999n, considerando-se os resultados obtidos para a nova proposta metodológica. É importante notar que os setores determinados como principais são diferentes dependendo do indicador econômico escolhido. Para identificar os setores-chave da economia utilizando os indicadores econômicos listados no quadro 5, estabeleceu-se o critério do setor ter sido indicado como tal em pelo menos quatro células. Portanto, os setores-chave seriam: 1-Agropecuária, 5-Siderurgia, 17-Refino de petróleo, 21-Indústria têxtil, 26-Abate de animais e 34-Comércio. Esta análise abrange somente os indicadores selecionados, porém, pode-se ampliar a avaliação incluindo os multiplicadores de produção, renda e emprego para a determinação dos setores-chave. 


\begin{tabular}{|c|c|c|c|c|c|c|c|c|c|}
\hline \multirow{3}{*}{ Setor } & \multirow{2}{*}{\multicolumn{3}{|c|}{ Multiplicadores }} & \multicolumn{6}{|c|}{ Índices de ligacões } \\
\hline & & & & \multicolumn{2}{|c|}{ RH } & \multicolumn{2}{|c|}{ GHS } & \multicolumn{2}{|c|}{ Campo } \\
\hline & GE & GR & MP & trás & frente & trás & frente & trás & frente \\
\hline $1 \quad$ Agropecuária & $\mathrm{x}$ & & & & $\mathrm{x}$ & & $\mathrm{x}$ & & $\mathrm{x}$ \\
\hline 2 Extrativa Mineral & & & & & & & & & \\
\hline 3 Petróleo e gás & & & & & & & & & \\
\hline 4 Minerais não-metálicos & & & & & & & & & \\
\hline 5 Siderurgia & & & & $\mathrm{x}$ & $\mathrm{x}$ & & & $\mathrm{x}$ & $\mathrm{x}$ \\
\hline 6 Metalurgia de não-ferrosos & & & & $\mathrm{x}$ & $\mathrm{x}$ & & & & \\
\hline 7 Outros Produtos Metalúrgicos & & & & $\mathrm{x}$ & $\mathrm{x}$ & & & & \\
\hline Máquinas e Equipamentos & & & & & & & & & \\
\hline $9 \quad$ Material Elétrico & & & & & & & & & \\
\hline 10 Equipamentos Eletrônicos & & & & & & & & & \\
\hline 11 Automóveis, caminhões e ônibus & & & & & & & & & \\
\hline 12 Peças e outros veículos & & & & & & & & & \\
\hline 13 Madeira e Mobiliário & & & & & & & & & \\
\hline 14 Celulose, Papel e Gráfica & & & & $\mathrm{x}$ & $\mathrm{x}$ & & & & \\
\hline 15 Indústria da Borracha & & & & & & & & & \\
\hline 16 Elementos Químicos & & & & & & & & & \\
\hline 17 Refino de Petróleo & & & & & $\mathrm{x}$ & & $\mathrm{x}$ & $\mathrm{x}$ & $\mathrm{x}$ \\
\hline 18 Químicos Diversos & & & & $\mathrm{x}$ & $\mathrm{x}$ & & & & \\
\hline 19 Farmacêuticos e Veterinários & & & & & & & & & \\
\hline 20 Artigos Plásticos & & & & & & & & & \\
\hline 21 Indústria Têxtil & & & & $\mathrm{x}$ & $\mathrm{x}$ & & & $\mathrm{x}$ & $\mathrm{x}$ \\
\hline 22 Artigos do Vestuário & $\mathrm{x}$ & & $\mathrm{x}$ & & & & & & \\
\hline 23 Calçados & & & & & & & & & \\
\hline 24 Indústria do Café & & & & & & & & & \\
\hline 25 Beneficiamento de Produtos Vegetais & & & & & & & & & \\
\hline 26 Abate de Animais & & & $\mathrm{x}$ & $\mathrm{x}$ & & $\mathrm{x}$ & & $\mathrm{x}$ & \\
\hline 27 Indústria de Laticínios & & & & & & & & $\mathrm{x}$ & \\
\hline 28 Fabricação de Açúcar & & & & & & & & & \\
\hline 29 Fabricação de Óleos Vegetais & & & & $\mathrm{x}$ & & & & & \\
\hline 30 Outros Produtos Alimentares & & & & & & & & & \\
\hline 31 Indústrias Diversas & & & & & & & & & \\
\hline 32 Serviços Industriais de Utilidade Pública & & & & & $\mathrm{x}$ & & $\mathrm{x}$ & & $\mathrm{x}$ \\
\hline 33 Construção Civil & & & & & & $\mathrm{x}$ & & & \\
\hline 34 Comércio & $\mathrm{x}$ & $\mathrm{x}$ & $\mathrm{x}$ & & $\mathrm{x}$ & & $\mathrm{x}$ & & \\
\hline 35 Supermercados & & & & $\mathrm{x}$ & & $\mathrm{x}$ & & & \\
\hline 36 Transportes & & & & & $\mathrm{x}$ & $\mathrm{x}$ & & & \\
\hline 37 Comunicações & & & & & & & & & \\
\hline 38 Instituições Financeiras & & $\mathrm{x}$ & & & & & & & \\
\hline 39 Serviços Prestados às Famílias & $\mathrm{x}$ & $\mathrm{x}$ & & & & $\mathrm{x}$ & & & \\
\hline 40 Serviços Prestados às Empresas & & & & & & & $\mathrm{x}$ & & \\
\hline 41 Aluguel de Imóveis & & & & & & & & & \\
\hline 42 Administração Pública & & $\mathrm{x}$ & $\mathrm{x}$ & & & $\mathrm{x}$ & & & \\
\hline 43 Serviços Privados não-mercantis & $\mathrm{x}$ & $\mathrm{x}$ & $\mathrm{x}$ & & & & & & \\
\hline
\end{tabular}

Quadro 5 - Comparação da determinação de setores-chave de acordo com a geração de de emprego (GE) e renda (GR), multiplicador de produção (MP) tipo II e índices de ligação de Rasmussen-Hirschman (RH), puros normalizados (GHS) e campo de influência (campo) para o ano de 1999n. 


\subsection{Comparação dos resultados da metodologia tradicional e nova proposta metodológica}

A Tabela 53 apresenta as diferenças dos valores calculados dos multiplicadores de emprego, renda e produção da nova proposta metodológica e metodologia tradicional para o ano de 1999. A análise dos dados indica que foram introduzidos efeitos diretos, indiretos e induzidos.Os efeitos diretos e indiretos gerados pela nova metodologia são representados pelas diferenças dos multiplicadores tipo I. O efeito total da incorporação dos valores das mercadorias comercializadas pelos supermercados como seus custos operacionais podem ser mensurados pelas diferenças dos multiplicadores tipo II.

Constata-se, observando as médias das diferenças, que o efeito induzido gerado pela nova metodologia é maior que os efeitos diretos e indiretos, pois as médias dos multiplicadores tipo II são no mínimo quatro vezes maiores que as médias dos multiplicadores tipo I. Portanto, variações das vendas do setor 35-Supermercados causam impactos em emprego, renda e produção sobre a economia principalmente por efeito induzido. Além disso, os impactos da variação das vendas do setor supermercadista sobre os setores de serviços ocorrem por efeito induzido e na indústria e agropecuária por efeito indireto.

Para identificar os setores mais influenciados pela comercialização de produtos em supermercados, foi elaborada a Tabela 54, que resume e classifica os efeitos diretos, indiretos e totais sobre a produção dos setores gerados pela nova metodologia. Nota-se que os efeitos diretos e indiretos são mais importantes para o próprio setor 35Supermercados e também para 34-Comércio, 30-Outros produtos alimentares, 23Calçados, 25-Beneficiamento de produtos vegetais, 28-Fabricação de açúcar, 29Fabricação de óleos vegetais, 26-Abate de animais e 11-Automóveis, caminhões e ônibus. Quando se levam em consideração os efeitos totais sobre a produção os principais setores influenciados pelos supermercados são: 34-Comércio, 35Supermercados, 42-Administração pública, 43-Serviços privados não-mercantis, 39Serviços prestados às famílias, 22-Artigos do vestuário, 13-Madeira e mobiliário, 30Outros produtos alimentares, 23-Calçados e 14-Celulose, papel e gráfica. Portanto, os setores de serviços sofrem o efeito induzido das vendas dos supermercados enquanto a indústria de alimentos é influenciada principalmente por efeito indireto. 
Tabela 53. Diferenças dos indicadores econômicos calculados para a metodologia tradicional e nova proposta metodológica (1999n-1999).

\begin{tabular}{|c|c|c|c|c|c|c|}
\hline \multirow[t]{2}{*}{ Setor } & \multicolumn{2}{|c|}{$\begin{array}{l}\text { Multiplicador } \\
\text { de emprego }\end{array}$} & \multicolumn{2}{|c|}{$\begin{array}{c}\text { Multiplicador } \\
\text { de renda }\end{array}$} & \multicolumn{2}{|c|}{$\begin{array}{l}\text { Multiplicador } \\
\text { de produção }\end{array}$} \\
\hline & I & II & I & II & I & II \\
\hline 1 Agropecuária & 0,03 & 0,24 & 0,19 & 1,20 & 0,04 & 0,54 \\
\hline 2 Extrativa Mineral & 0,20 & 1,31 & 0,16 & 1,01 & 0,04 & 0,52 \\
\hline 3 Petróleo e gás & 0,81 & 8,52 & 0,16 & 1,62 & 0,02 & 0,46 \\
\hline 4 Minerais não-metálicos & 0,23 & 1,39 & 0,14 & 0,86 & 0,04 & 0,53 \\
\hline $5 \quad$ Siderurgia & 2,15 & 11,91 & 0,88 & 4,66 & 0,04 & 0,47 \\
\hline 6 Metalurgia de não-ferrosos & 1,60 & 7,67 & 0,73 & 3,31 & 0,05 & 0,50 \\
\hline 7 Outros Produtos Metalúrgicos & 0,21 & 1,21 & 0,11 & 0,62 & 0,05 & 0,56 \\
\hline 8 Máquinas e Equipamentos & 0,31 & 2,14 & 0,10 & 0,62 & 0,04 & 0,53 \\
\hline 9 Material Elétrico & 0,86 & 3,92 & 0,27 & 1,19 & 0,06 & 0,55 \\
\hline 10 Equipamentos Eletrônicos & 0,68 & 3,49 & 0,21 & 1,08 & 0,05 & 0,50 \\
\hline 11 Automóveis, caminhões e ônibus & 2,13 & 8,81 & 0,48 & 1,91 & 0,07 & 0,56 \\
\hline 12 Peças e outros veículos & 0,71 & 3,36 & 0,17 & 0,80 & 0,06 & 0,58 \\
\hline 13 Madeira e Mobiliário & 0,13 & 0,70 & 0,16 & 0,78 & 0,06 & 0,65 \\
\hline 14 Celulose, Papel e Gráfica & 0,50 & 2,43 & 0,20 & 0,94 & 0,06 & 0,63 \\
\hline 15 Indústria da Borracha & 1,12 & 5,14 & 0,38 & 1,67 & 0,06 & 0,52 \\
\hline 16 Elementos Químicos & 1,01 & 7,26 & 0,27 & 1,83 & 0,03 & 0,46 \\
\hline 17 Refino de Petróleo & 5,08 & 35,48 & 0,94 & 6,33 & 0,02 & 0,41 \\
\hline 18 Químicos Diversos & 0,79 & 4,39 & 0,21 & 1,10 & 0,05 & 0,49 \\
\hline 19 Farmacêuticos e Veterinários & 0,96 & 4,71 & 0,26 & 1,22 & 0,06 & 0,58 \\
\hline 20 Artigos Plásticos & 0,23 & 1,39 & 0,10 & 0,58 & 0,05 & 0,52 \\
\hline 21 Indústria Têxtil & 0,63 & 2,75 & 0,39 & 1,65 & 0,06 & 0,57 \\
\hline 22 Artigos do Vestuário & 0,05 & 0,25 & 0,16 & 0,81 & 0,06 & 0,66 \\
\hline 23 Calçados & 0,14 & 0,68 & 0,17 & 0,77 & 0,07 & 0,64 \\
\hline 24 Indústria do Café & 0,76 & 4,37 & 0,52 & 2,84 & 0,04 & 0,54 \\
\hline 25 Beneficiamento de Produtos Vegetais & 0,63 & 2,84 & 0,53 & 2,26 & 0,07 & 0,62 \\
\hline 26 Abate de Animais & 0,83 & 3,89 & 0,56 & 2,50 & 0,07 & 0,63 \\
\hline 27 Indústria de Laticínios & 0,87 & 4,55 & 0,44 & 2,16 & 0,05 & 0,52 \\
\hline 28 Fabricação de Açúcar & 0,71 & 3,42 & 0,30 & 1,40 & 0,07 & 0,60 \\
\hline 29 Fabricação de Óleos Vegetais & 3,61 & 16,07 & 1,66 & 7,11 & 0,07 & 0,60 \\
\hline 30 Outros Produtos Alimentares & 0,44 & 1,92 & 0,34 & 1,41 & 0,08 & 0,65 \\
\hline 31 Indústrias Diversas & 0,18 & 1,02 & 0,17 & 0,94 & 0,04 & 0,56 \\
\hline 32 Serviços Industriais de Utilidade Pública & 0,32 & 5,56 & 0,03 & 0,50 & 0,01 & 0,45 \\
\hline 33 Construção Civil & 0,13 & 0,91 & 0,20 & 1,36 & 0,03 & 0,49 \\
\hline 34 Comércio & 0,03 & 0,39 & 0,04 & 0,45 & 0,64 & 2,96 \\
\hline 35 Supermercados & 5,52 & 11,24 & 6,32 & 14,38 & 1,02 & 0,98 \\
\hline 36 Transportes & 0,13 & 0,81 & 0,10 & 0,59 & 0,05 & 0,61 \\
\hline 37 Comunicações & 0,23 & 3,98 & 0,03 & 0,37 & 0,01 & 0,48 \\
\hline 38 Instituições Financeiras & 0,18 & 3,32 & 0,01 & 0,27 & 0,01 & 0,58 \\
\hline 39 Serviços Prestados às Famílias & 0,05 & 0,34 & 0,05 & 0,39 & 0,04 & 0,67 \\
\hline 40 Serviços Prestados às Empresas & 0,05 & 0,62 & 0,03 & 0,33 & 0,02 & 0,60 \\
\hline 41 Aluguel de Imóveis & 0,08 & 8,25 & 0,03 & 3,67 & 0,00 & 0,37 \\
\hline 42 Administração Pública & 0,10 & 1,29 & 0,02 & 0,25 & 0,02 & 0,72 \\
\hline 43 Serviços Privados não-mercantis & 0,00 & 0,07 & 0,00 & 0,13 & 0,00 & 0,72 \\
\hline Médias & 0,82 & 4,51 & 0,42 & 1,86 & 0,08 & 0,62 \\
\hline
\end{tabular}


Tabela 54. Classificação das diferenças do multiplicador de produção tipo I e II calculado para a metodologia tradicional e nova proposta metodológica (1999n-1999).

\begin{tabular}{|c|c|c|c|c|}
\hline \multirow[t]{2}{*}{ Setor } & \multicolumn{2}{|c|}{ ordem } & \multicolumn{2}{|c|}{$\begin{array}{l}\text { Multiplicador } \\
\text { de produção }\end{array}$} \\
\hline & $\mathrm{I}$ & II & I & II \\
\hline Agropecuária & 27 & 25 & 0,04 & 0,54 \\
\hline Extrativa Mineral & 31 & 29 & 0,04 & 0,52 \\
\hline Petróleo e gás & 37 & 39 & 0,02 & 0,46 \\
\hline Minerais não-metálicos & 29 & 27 & 0,04 & 0,53 \\
\hline Siderurgia & 32 & 38 & 0,04 & 0,47 \\
\hline Metalurgia de não-ferrosos & 19 & 33 & 0,05 & 0,50 \\
\hline Outros Produtos Metalúrgicos & 23 & 21 & 0,05 & 0,56 \\
\hline Máquinas e Equipamentos & 30 & 28 & 0,04 & 0,53 \\
\hline 9 Material Elétrico & 15 & 24 & 0,06 & 0,55 \\
\hline 10 Equipamentos Eletrônicos & 22 & 34 & 0,05 & 0,50 \\
\hline 11 Automóveis, caminhões e ônibus & 9 & 22 & 0,07 & 0,56 \\
\hline 12 Peças e outros veículos & 13 & 17 & 0,06 & 0,58 \\
\hline 13 Madeira e Mobiliário & 11 & 7 & 0,06 & 0,65 \\
\hline 14 Celulose, Papel e Gráfica & 12 & 10 & 0,06 & 0,63 \\
\hline 15 Indústria da Borracha & 16 & 30 & 0,06 & 0,52 \\
\hline 16 Elementos Químicos & 34 & 40 & 0,03 & 0,46 \\
\hline 17 Refino de Petróleo & 38 & 42 & 0,02 & 0,41 \\
\hline 18 Químicos Diversos & 20 & 35 & 0,05 & 0,49 \\
\hline 19 Farmacêuticos e Veterinários & 17 & 18 & 0,06 & 0,58 \\
\hline 20 Artigos Plásticos & 18 & 31 & 0,05 & 0,52 \\
\hline 21 Indústria Têxtil & 14 & 20 & 0,06 & 0,57 \\
\hline 22 Artigos do Vestuário & 10 & 6 & 0,06 & 0,66 \\
\hline 23 Calçados & 4 & 9 & 0,07 & 0,64 \\
\hline 24 Indústria do Café & 28 & 26 & 0,04 & 0,54 \\
\hline 25 Beneficiamento de Produtos Vegetais & 5 & 12 & 0,07 & 0,62 \\
\hline 26 Abate de Animais & 8 & 11 & 0,07 & 0,63 \\
\hline 27 Indústria de Laticínios & 24 & 32 & 0,05 & 0,52 \\
\hline 28 Fabricação de Açúcar & 6 & 14 & 0,07 & 0,60 \\
\hline 29 Fabricação de Óleos Vegetais & 7 & 15 & 0,07 & 0,60 \\
\hline 30 Outros Produtos Alimentares & 3 & 8 & 0,08 & 0,65 \\
\hline 31 Indústrias Diversas & 26 & 23 & 0,04 & 0,56 \\
\hline 32 Serviços Industriais de Utilidade Pública & 41 & 41 & 0,01 & 0,45 \\
\hline 33 Construção Civil & 33 & 36 & 0,03 & 0,49 \\
\hline 34 Comércio & 2 & 1 & 0,64 & 2,96 \\
\hline 35 Supermercados & 1 & 2 & 1,02 & 0,98 \\
\hline 36 Transportes & 21 & 13 & 0,05 & 0,61 \\
\hline 37 Comunicações & 40 & 37 & 0,01 & 0,48 \\
\hline 38 Instituições Financeiras & 39 & 19 & 0,01 & 0,58 \\
\hline 39 Serviços Prestados às Famílias & 25 & 5 & 0,04 & 0,67 \\
\hline 40 Serviços Prestados às Empresas & 36 & 16 & 0,02 & 0,60 \\
\hline 41 Aluguel de Imóveis & 43 & 43 & 0,00 & 0,37 \\
\hline 42 Administração Pública & 35 & 3 & 0,02 & 0,72 \\
\hline 43 Serviços Privados não-mercantis & 42 & 4 & 0,00 & 0,72 \\
\hline
\end{tabular}




\section{CONCLUSÕES}

A análise dos índices de ligações intersetoriais mostra que na classificação dos valores de índices puros normalizados totais o setor supermercadista consta como o primeiro da classificação, valores calculados de acordo com a nova proposta metodológica. Levando-se em consideração outros indicadores econômicos, como os multiplicadores de produção, emprego, renda e a capacidade de geração de Imposto de Circulação de Mercadorias e Serviços, o Setor 35-Supermercados é classificado sempre entre os primeiros sete setores mais importantes no ano de 1999.

Os setores mais influenciados em termos de produção, emprego e renda pela variação da produção do setor Supermercados são aqueles pertencentes ao segmento da indústria de alimentos, a qual engloba os setores 25-Beneficiamento de produtos vegetais, 30-Outros produtos alimentares e 27-Indústria de laticínios. Devem-se destacar também os setores 1-Agropecuária e 34-Comércio, este último principalmente por efeito induzido. Existem setores que são menos influenciados pela variação da produção do setor supermercadista que os citados anteriormente, mas apresentam uma influência crescente por parte dos Supermercados: 20-Artigos plásticos, 14-Celulose, papel e gráfica; 16-Elementos químicos e 32-Serviços industriais de utilidade pública. Deve-se ainda destacar a crescente importância das empresas supermercadistas como clientes do setor 40-Serviços prestados às empresas, que abrange serviços de consultoria e propaganda.

O produto interno bruto (PIB) setorial dos Supermercados apresentou um aumento no período 1995/99 de $\mathrm{R} \$ 45,1$ para $\mathrm{R} \$ 46,8$ bilhões (valores para a nova proposta metodológica), e sua participação no PIB nacional se mantendo em 
aproximadamente 5\%. O PIB setorial dos supermercados se manteve estável no período 1995/99 porque o valor real dos salários e o excedente operacional bruto diminuíram influenciados respectivamente pela maior taxa de desemprego que causa a diminuição do salário médio e maior competição entre as empresas do setor, que influencia a diminuição do lucro. A maior participação no PIB setorial dos Supermercados pertence aos setores de serviços, ou seja, a maior parte do valor adicionado é dada pelos serviços prestados incluindo transporte, seguros e propaganda. A produtividade do trabalho dentro da cadeia de produção e distribuição se manteve a mesma durante a década de 1990, mas diminuiu dentro do setor supermercadista.

A capacidade de geração de empregos diretos do setor supermercadista também diminuiu no período 1990/99, porém, em menor intensidade que a economia como um todo. Por outro lado, a sua capacidade de geração de empregos indiretos e induzidos aumentou, como um resultado do aumento da participação nas vendas do Comércio e comercialização de itens não-alimentos. $O$ setor mais fortemente impactado em geração de empregos pelo aumento das vendas do setor supermercadista é a Agropecuária, o qual é fornecedor de produtos para o varejo e matéria-prima para a indústria de alimentos.

Em relação à renda, a capacidade de geração de salários diretos (dentro do próprio setor) dos Supermercados diminuiu, porém, dado o forte efeito induzido sobre os outros setores, o valor total de salários pagos por valor da produção aumentou consideravelmente. O setor também apresentou importante capacidade de geração de Imposto sobre Circulação de Mercadorias e Serviços e o valor de ICMS gerado por valor de produção dos Supermercados aumentou no período 1990/99.

Analisando o setor supermercadista pela nova proposta metodológica, observouse claramente que esta se mostrou eficiente para mensurar efeitos induzidos sobre os outros setores da economia, o que a metodologia tradicional não permite captar. Além disso, deve-se levar em conta que o efeito induzido considerado nos indicadores econômicos dos demais setores da economia torna possível determinar melhor quais os mais influenciados pelas variações da demanda final dos Supermercados. 
Os resultados da pesquisa indicam que existem ganhos para a sociedade com a expansão do setor supermercadista em termos de geração de empregos, impostos e aumento de produção. Estes ganhos são realizados por efeitos diretos, indiretos e principalmente por efeito induzido. A respeito da geração de empregos e do multiplicador de produção, os valores apresentados para os 35-Supermercados são maiores que para o 34-Comércio. Deve-se salientar que a matriz de insumo-produto incorpora o setor informal da economia. Portanto, o aumento de produção do 34Comércio como um todo levaria à geração de empregos em parte informais (sem carteira de trabalho). A participação do setor informal no setor supermercadista é relativamente menor que no comércio em geral, o que constitui uma vantagem na expansão desta atividade.

O Imposto sobre Circulação de Mercadorias e Serviços é atualmente a principal fonte de recursos para os estados e o setor supermercadista é uma das atividades econômicas com maior capacidade de gerar aumento substancial do montante arrecadado. Portanto, o apoio do governo para a expansão do setor supermercadista, principalmente das pequenas empresas, levaria a um aumento de produção, geração de empregos formais e impostos consideravelmente maior que outras atividades do setor Comércio.

A reforma tributária e o combate à sonegação são as principais medidas para estimular a expansão dos supermercados. Um exemplo de modificação da legislação é a dupla tributação do ICMS que sofrem as pequenas empresas supermercadistas que se unem em associações, adquirindo seus produtos em conjunto utilizando centrais de compra, como foi analisado anteriormente. A dupla tributação ocorre quando o produto é transferido da central de compras para as lojas associadas, o que diminui a competitividade das pequenas empresas do setor. Outra modificação da legislação de grande interesse do setor é que seja permitida a venda de medicamentos que não exijam receita médica em supermercados, medida que possibilitaria a queda de preços destes produtos para a população. 
Sugestões para o desenvolvimento de novos estudos sobre o comércio incluem a análise detalhada de inovações tecnológicas implementadas pelo setor supermercadista e seus impactos sobre as indústrias diretamente relacionadas. Além disso, torna-se importante analisar os problemas mais abrangentes do comércio, como tributação, sonegação fiscal e, mais recentemente, o agravamento do problema de roubo de cargas e receptação de mercadorias.

Outra proposta de pesquisa é a desagregação do setor Supermercados para outros períodos, o que possibilitaria uma análise mais abrangente do setor. Recomenda-se a análise para o final da década de 1980, quando os supermercados passavam por profunda crise que se refletia na diminuição do número de lojas e do faturamento bruto.

A modernização do setor supermercadista por investimentos em automação comercial, reforma de lojas e inovações no atendimento ao cliente traz inúmeros benefícios ao consumidor. A maior qualidade dos serviços prestados, maior interação entre indústria e varejo para o lançamento de novos produtos e diminuição de preços são vantagens que o consumidor pode notar em suas compras. É importante citar que a nãomensuração destes benefícios é uma limitação da pesquisa apresentada e que pode se tornar tema de trabalhos futuros.

A desagregação de outros setores do comércio, tais como Varejo de combustíveis, Varejo de veículos e peças e/ou Atacado na matriz de insumo-produto do Brasil para diversos anos permitiria uma análise mais completa destas atividades. A atual agregação do setor Comércio nas Contas Nacionais, publicadas pelo IBGE, e sua matriz de insumo-produto é relativamente alta, englobando atividades que diferem significativamente em suas características, como é o caso do setor supermercadista. 
ANEXOS 
ANEXO A - Critérios de desagregação do setor supermercadista do setor original 34Comércio dentro da matriz de uso utilizando dados da Pesquisa Anual de Comércio do Instituto Brasileiro de Geografia e Estatística (PAC-IBGE) e da Associação Brasileira de Supermercados (ABRAS).

\begin{tabular}{|c|c|c|}
\hline Código & Produto & Critério de desagregação \\
\hline 0101 & CAFÉ EM COCO & \\
\hline 0102 & CANA-DE-AÇÚCAR & \\
\hline 0103 & ARROZ EM CASCA & \\
\hline 0104 & TRIGO EM GRÃO & \\
\hline 0105 & SOJA EM GRÃO & \\
\hline 0106 & ALGODÃO EM CAROÇO & \\
\hline 0107 & MILHO EM GRÃO & \\
\hline 0108 & BOVINOS E SUÍNOS & \\
\hline 0109 & LEITE NATURAL & \\
\hline 0110 & AVES VIVAS & \\
\hline 0199 & OUT. PROD. AGROPECUÁRIOS & \\
\hline 0201 & MINÉRIO DE FERRO & \\
\hline 0202 & OUTROS MINERAIS & \\
\hline 0301 & PETRÓLEO E GÁS & \\
\hline 0302 & CARVÃO E OUTROS & \\
\hline 0401 & PROD. MINERAIS Ñ METÁLICOS & \\
\hline 0501 & PROD. SIDERÚRGICOS BÁSICOS & \\
\hline 0502 & LAMINADOS DE AÇO & \\
\hline 0601 & PROD. METALÚRG. Ñ FERROSOS & \\
\hline 0701 & OUT. PROD. METALÚRGICOS & $\begin{array}{l}\text { Aquisições de máquinas } \\
\text { e equipamentos (PAC-IBGE) }\end{array}$ \\
\hline 0801 & FABRIC. E MANUT. MAQ. E EQUIP. & $\begin{array}{l}\text { Aquisições de máquinas } \\
\text { e equipamentos (PAC-IBGE) }\end{array}$ \\
\hline 0802 & TRATORES E MAQ. TERRAPLAN. & \\
\hline 1001 & MATERIAL ELÉTRICO & $\begin{array}{l}\text { Aquisições de máquinas } \\
\text { e equipamentos (PAC-IBGE) }\end{array}$ \\
\hline 1101 & EQUIPAMENTOS ELETRÔNICOS & \\
\hline 1201 & AUTOM.,CAMINHÕES E ÔNIBUS & \\
\hline 1301 & OUTROS VEÍCULOS E PEÇAS & \\
\hline 1401 & MADEIRA E MOBILIÁRIO & $\begin{array}{l}\text { Outras despesas operacionais } \\
\text { e não-operacionais (PAC-IBGE) }\end{array}$ \\
\hline 1501 & PAPEL,CELUL.PAPELÃO E ARTEF. & $\begin{array}{l}\text { Compras de matéria-prima } \\
\text { e embalagem (PAC-IBGE) }\end{array}$ \\
\hline 1601 & PRODUTOS DA BORRACHA & \\
\hline 1701 & ELEM. QUÍM. Ñ PETROQUÍMICOS & \\
\hline 1702 & ÁLCOOL DE CANA E CEREAIS & \\
\hline 1801 & GASOLINA PURA & \\
\hline 1802 & ÓLEOS COMBUSTÍVEIS & \\
\hline 1803 & OUTROS PROD. DO REFINO & \\
\hline 1804 & PROD. PETROQUÍMICOS BÁSICOS & \\
\hline
\end{tabular}


ANEXO A - Critérios de desagregação do setor supermercadista do setor original 34Comércio dentro da matriz de uso utilizando dados da Pesquisa Anual de Comércio do Instituto Brasileiro de Geografia e Estatística (PAC-IBGE) e da Associação Brasileira de Supermercados (ABRAS).

\begin{tabular}{|c|c|c|}
\hline Código & Produto & Critério de desagregação \\
\hline 1805 & RESINAS & \\
\hline 1806 & GASOALCOOL & $\begin{array}{l}\text { Outras despesas operacionais } \\
\text { e não-operacionais (PAC-IBGE) }\end{array}$ \\
\hline 1901 & ADUBOS & \\
\hline 1902 & TINTAS & \\
\hline 1903 & OUTROS PROD. QUÍMICOS & \\
\hline 2001 & PROD. FARM. E DE PERFUMARIA & \\
\hline 2101 & ARTIGOS DE PLÁSTICO & $\begin{array}{l}\text { Compras de matéria-prima } \\
\text { e embalagem (PAC-IBGE) }\end{array}$ \\
\hline 2201 & FIOS TÊXTEIS NATURAIS & $\begin{array}{l}\text { Compras de matéria-prima } \\
\text { e embalagem (PAC-IBGE) }\end{array}$ \\
\hline 2202 & TECIDOS NATURAIS & \\
\hline 2203 & FIOS TÊXTEIS ARTIFICIAIS & \\
\hline 2204 & TECIDOS ARTIFICIAIS & \\
\hline 2205 & OUTROS PROD. TÊXTEIS & $\begin{array}{l}\text { Compras de matéria-prima } \\
\text { e embalagem (PAC-IBGE) }\end{array}$ \\
\hline 2301 & ARTIGOS DO VESTUÁRIO & $\begin{array}{l}\text { Compras de matéria-prima } \\
\text { e embalagem (PAC-IBGE) }\end{array}$ \\
\hline 2401 & PROD. COURO E CALÇADOS & \\
\hline 2501 & PRODUTOS DO CAFÉ & \\
\hline 2601 & ARROZ BENEFICIADO & \\
\hline 2602 & FARINHA DE TRIGO & \\
\hline 2603 & OUT. PROD. ALIMENT. BENEFIC. & \\
\hline 2701 & CARNE BOVINA & \\
\hline 2702 & CARNE DE AVES ABATIDAS & \\
\hline 2801 & LEITE BENEFICIADO & \\
\hline 2802 & OUTROS LATICÍNIOS & \\
\hline 2901 & AÇÚCAR & \\
\hline 3001 & OLEO VEGETAL EM BRUTO & \\
\hline 3002 & OLEO VEGETAL REFINADO & \\
\hline 3101 & RAÇÕES E OUT. ALIMENTARES & \\
\hline 3102 & BEBIDAS & \\
\hline 3201 & PRODUTOS DIVERSOS & $\begin{array}{l}\text { Compras de matéria-prima } \\
\text { e embalagem (PAC-IBGE) }\end{array}$ \\
\hline 3301 & SERV. INDUST. DE UTIL. PÚBLICA & $\begin{array}{l}\text { Serviços de utilidade pública } \\
\text { e comunicações (PAC-IBGE) }\end{array}$ \\
\hline 3401 & PROD. DA CONSTRUÇÃO CIVIL & $\begin{array}{l}\text { Aquisições de edificações } \\
\text { (PAC-IBGE) }\end{array}$ \\
\hline 3501 & MARGEM DE COMÉRCIO & $\begin{array}{l}\text { Margem aplicada ao } \\
\text { total dos produtos }\end{array}$ \\
\hline 3601 & MARGEM DE TRANSPORTE & $\begin{array}{l}\text { Margem aplicada ao } \\
\text { total dos produtos }\end{array}$ \\
\hline
\end{tabular}


ANEXO A - Critérios de desagregação do setor supermercadista do setor original 34Comércio dentro da matriz de uso utilizando dados da Pesquisa Anual de Comércio do Instituto Brasileiro de Geografia e Estatística (PAC-IBGE) e da Associação Brasileira de Supermercados (ABRAS).

\begin{tabular}{|c|c|c|}
\hline \multicolumn{2}{|c|}{ Código Produto } & \multirow{2}{*}{$\begin{array}{l}\text { Critério de desagregação } \\
\text { Serviços de utilidade pública } \\
\text { e comunicações (PAC-IBGE) }\end{array}$} \\
\hline 3701 & COMUNICAÇÕES & \\
\hline 3801 & SEGUROS & Pagamentos de seguros (PAC-IBGE) \\
\hline 3802 & SERVIÇOS FINANCEIROS & Despesas financeiras (PAC-IBGE) \\
\hline 3901 & ALOJAMENTO E ALIMENTAÇÃO & $\begin{array}{l}\text { Porcentagem das } \\
\text { pesssoas empregadas (PAC-IBGE) }\end{array}$ \\
\hline 3902 & OUTROS SERVIÇOS & $\begin{array}{l}\text { Outras despesas operacionais } \\
\text { e não-operacionais (PAC-IBGE) }\end{array}$ \\
\hline 3903 & SAÚDE E EDUC.MERCANTIS & \\
\hline 4001 & SERV. PREST. À EMPRESA & $\begin{array}{l}\text { Servicos prestados por terceiros } \\
\text { (consultoria, propaganda e outros) }\end{array}$ \\
\hline 4101 & ALUGUEL DE IMÓVEIS & $\begin{array}{l}\text { Aluguel de imóveis e pagamento de } \\
\text { condomínios (PAC-IBGE) }\end{array}$ \\
\hline 4102 & ALUGUEL IMPUTADO & \\
\hline 4201 & ADMINISTRAÇÃO PÚBLICA & \\
\hline 4202 & SAÚDE PÚBLICA & \\
\hline 4203 & EDUCAÇÃO PÚBLICA & \\
\hline \multirow[t]{11}{*}{4301} & SERV. Ñ MERCANTIL PRIVADO & \\
\hline & PRODUÇÃO NACIONAL & \\
\hline & IMPORTADO & Planilha de importação (IBGE) \\
\hline & IMPOSTO DE IMPORTAÇÃO & $\begin{array}{l}\text { Planilha de imposto (IBGE) } \\
\text { de importação }\end{array}$ \\
\hline & ICMS NACIONAL & Planilha de ICMS (IBGE) \\
\hline & ICMS IMPORTADO & Planilha de ICMS (IBGE) \\
\hline & IPI NACIONAL & Planilha de IPI (IBGE) \\
\hline & IPI IMPORTADO & Planilha de IPI (IBGE) \\
\hline & $\begin{array}{l}\text { OUTROS IMPOSTOS INDIRETOS } \\
\text { LÍQUIDOS - NACIONAL }\end{array}$ & $\begin{array}{l}\text { Planilha de outros impostos } \\
\text { indiretos líquidos (IBGE) }\end{array}$ \\
\hline & OUTROS IIL - IMPORTADO & $\begin{array}{l}\text { Planilha de outros impostos } \\
\text { indiretos líquidos (IBGE) }\end{array}$ \\
\hline & CONSUMO INTERMEDIÁRIO & \\
\hline R10 & REMUNERAÇÕES & \\
\hline R11 & SALÁRIOS & $\begin{array}{l}\text { Pesquisa Anual do Comércio } \\
\text { (PAC-IGE) }\end{array}$ \\
\hline \multirow[t]{3}{*}{ R12 } & CONTRIBUIÇÕES SOCIAIS EFETIVAS & \\
\hline & PREVIDÊNCIA OFICIAL / FGTS & $\begin{array}{l}\text { Razão do setor original: } \\
\text { Prev. Oficial e FGTS/Salários) }\end{array}$ \\
\hline & PREVIDÊNCIA PRIVADA & $\begin{array}{l}\text { Razão do setor original: } \\
\text { Prev. privada/Salários) }\end{array}$ \\
\hline R13 & CONTRIBUIÇÕES SOCIAIS FICTÍCIAS & \\
\hline
\end{tabular}


ANEXO A - Critérios de desagregação do setor supermercadista do setor original 34Comércio dentro da matriz de uso utilizando dados da Pesquisa Anual de Comércio do Instituto Brasileiro de Geografia e Estatística (PAC-IBGE) e da Associação Brasileira de Supermercados (ABRAS).

\begin{tabular}{cll}
\hline Código Produto & Critério de desagregação \\
\hline N2 & EXCEDENTE OPERACIONAL BRUTO (EOB) & \\
& RENDIMENTO DE AUTÔNOMOS & Retiradas de proprietários (PAC) \\
& EOB EXCLUSIVE RENDIMENTOS & Lucro líquido (ABRAS) \\
DE AUTÔNOMOS & VALOR ADICIONADO CUSTO FATORES & $\begin{array}{l}\text { Razão do setor original: } \\
\text { Outros impostos./(Produção nacional + } \\
\text { importada) }\end{array}$ \\
R22 & OUTROS IMPOSTOS SOBRE A PRODUÇÃO & Participação (\%) do consumo intermediário \\
R32 & OUTROS SUBSÍDIOS À PRODUÇÃO & \\
N1 & VALOR ADICIONADO PREÇO BÁSICO & Dados da Associação \\
P10 & VALOR DA PRODUÇÃO & Brasileira de Supermercados \\
& PESSOAL OCUPADO &
\end{tabular}


ANEXO B - Matriz de insumo-produto do Brasil do ano de 1990, valores nominais em milhões de $\mathrm{Cr} \$$ (metodologia tradicional).

\begin{tabular}{|c|c|c|c|c|c|c|c|c|c|c|c|c|c|c|c|c|c|}
\hline Setores & 1 & 2 & 3 & 4 & 5 & 6 & 7 & 8 & 9 & 10 & 11 & 12 & 13 & 14 & 15 & 16 & 17 \\
\hline 1 Agropecuária & 529 & 0 & 0 & 4 & 49 & 1 & 0 & 0 & 0 & 0 & 0 & 0 & 81 & 18 & 11 & 138 & $\overline{0}$ \\
\hline 2 Extrativa Mineral & 15 & 22 & 1 & 43 & 26 & 26 & 4 & 2 & 2 & 2 & 0 & 1 & 0 & 3 & 0 & 14 & 2 \\
\hline 3 Petróleo e gás & 0 & 0 & 2 & 1 & 3 & 1 & 1 & 1 & 0 & 1 & 1 & 1 & 0 & 2 & 0 & 1 & 409 \\
\hline 4 Minerais não-metálicos & 4 & 6 & 3 & 194 & 11 & 8 & 10 & 9 & 14 & 10 & 7 & 6 & 4 & 2 & 0 & 7 & 3 \\
\hline 5 Siderurgia & 0 & 1 & 3 & 13 & 515 & 5 & 276 & 84 & 25 & 7 & 31 & 49 & 5 & 4 & 1 & 1 & 8 \\
\hline 6 Metalurgia de não-ferrosos & 0 & 0 & 1 & 1 & 14 & 169 & 60 & 28 & 76 & 12 & 6 & 40 & 3 & 6 & 1 & 2 & 2 \\
\hline 7 Outros Produtos Metalúrgicos & 7 & 14 & 15 & 10 & 32 & 12 & 103 & 147 & 42 & 22 & 25 & 126 & 18 & 6 & 4 & 6 & 12 \\
\hline 8 Máquinas e Equipamentos & 11 & 23 & 38 & 22 & 51 & 14 & 32 & 167 & 40 & 12 & 21 & 47 & 8 & 23 & 5 & 27 & 33 \\
\hline 9 Material Elétrico & 0 & 1 & 1 & 1 & 5 & 1 & 4 & 38 & 91 & 34 & 3 & 8 & 1 & 1 & 0 & 2 & 2 \\
\hline 10 Equipamentos Eletrônicos & 0 & 1 & 1 & 2 & 3 & 1 & 1 & 11 & 7 & 160 & 1 & 3 & 1 & 1 & 0 & 1 & 1 \\
\hline 11 Automóveis, caminhões e ônibus & 0 & 0 & 1 & 1 & 3 & 1 & 2 & 3 & 1 & 0 & 16 & 7 & 1 & 2 & 0 & 1 & 3 \\
\hline 12 Peças e outros veículos & 1 & 1 & 1 & 0 & 2 & 2 & 2 & 26 & 2 & 1 & 250 & 172 & 1 & 1 & 1 & 1 & 2 \\
\hline 13 Madeira e Mobiliário & 4 & 1 & 1 & 1 & 2 & 2 & 4 & 4 & 3 & 13 & 4 & 6 & 116 & 8 & 0 & 0 & 2 \\
\hline 14 Celulose, Papel e Gráfica & 2 & 2 & 4 & 17 & 6 & 4 & 11 & 8 & 9 & 7 & 3 & 6 & 6 & 293 & 1 & 3 & 14 \\
\hline 15 Indústria da Borracha & 0 & 2 & 1 & 3 & 6 & 1 & 4 & 14 & 3 & 1 & 34 & 10 & 3 & 3 & 94 & 2 & 2 \\
\hline 16 Elementos Químicos & 9 & 1 & 0 & 10 & 8 & 17 & 4 & 2 & 2 & 1 & 1 & 1 & 1 & 19 & 2 & 25 & 47 \\
\hline 17 Refino de Petróleo & 111 & 23 & 7 & 52 & 29 & 9 & 20 & 16 & 21 & 5 & 9 & 17 & 22 & 34 & 50 & 31 & 591 \\
\hline 18 Químicos Diversos & 343 & 12 & 3 & 17 & 10 & 15 & 13 & 9 & 9 & 2 & 11 & 7 & 22 & 45 & 10 & 7 & 21 \\
\hline 19 Farmacêuticos e Veterinários & 16 & 0 & 0 & 0 & 1 & 1 & 0 & 0 & 0 & 0 & 0 & 0 & 0 & 1 & 0 & 1 & 1 \\
\hline 20 Artigos Plásticos & 12 & 1 & 1 & 3 & 1 & 2 & 6 & 11 & 21 & 19 & 9 & 12 & 26 & 5 & 1 & 1 & 4 \\
\hline 21 Indústria Têxtil & 9 & 1 & 1 & 2 & 2 & 1 & 1 & 3 & 1 & 1 & 3 & 4 & 10 & 4 & 17 & 1 & 4 \\
\hline 22 Artigos do Vestuário & 0 & 1 & 1 & 0 & 2 & 1 & 1 & 1 & 0 & 0 & 2 & 1 & 1 & 1 & 0 & 1 & 2 \\
\hline 23 Calçados & 2 & 0 & 0 & 0 & 1 & 0 & 0 & 1 & 0 & 0 & 1 & 0 & 2 & 1 & 1 & 0 & 1 \\
\hline 24 Indústria do Café & 0 & 0 & 0 & 0 & 0 & 0 & 0 & 0 & 0 & 0 & 0 & 0 & 0 & 0 & 0 & 0 & 0 \\
\hline 25 Beneficiamento de Produtos Vegetais & 3 & 0 & 0 & 0 & 1 & 0 & 0 & 1 & 0 & 0 & 0 & 0 & 1 & 3 & 0 & 0 & 1 \\
\hline 26 Abate de Animais & 2 & 0 & 0 & 0 & 0 & 0 & 0 & 0 & 0 & 0 & 0 & 0 & 0 & 0 & 0 & 0 & 0 \\
\hline 27 Indústria de Laticínios & 0 & 0 & 0 & 0 & 0 & 0 & 0 & 0 & 0 & 0 & 0 & 0 & 0 & 0 & 0 & 0 & 0 \\
\hline 28 Fabricação de Açúcar & 0 & 0 & 0 & 0 & 1 & 0 & 0 & 0 & 0 & 0 & 0 & 0 & 0 & 1 & 0 & 26 & 2 \\
\hline 29 Fabricação de Óleos Vegetais & 25 & 0 & 0 & 0 & 0 & 0 & 0 & 1 & 0 & 0 & 0 & 3 & 0 & 2 & 0 & 5 & 5 \\
\hline 30 Outros Produtos Alimentares & 143 & 0 & 0 & 1 & 0 & 0 & 1 & 1 & 0 & 0 & 0 & 0 & 1 & 1 & 0 & 3 & 1 \\
\hline 31 Indústrias Diversas & 1 & 2 & 11 & 2 & 29 & 13 & 8 & 7 & 6 & 4 & 11 & 7 & 2 & 21 & 2 & 8 & 39 \\
\hline 32 Serviços Industriais de Utilidade Pública & 20 & 16 & 10 & 32 & 45 & 31 & 23 & 19 & 7 & 4 & 5 & 11 & 15 & 33 & 4 & 33 & 34 \\
\hline 33 Construção Civil & 0 & 1 & 3 & 2 & 1 & 1 & 2 & 3 & 1 & 1 & 1 & 2 & 1 & 3 & 0 & 2 & 3 \\
\hline 34 Comércio & 109 & 13 & 11 & 18 & 31 & 10 & 41 & 48 & 33 & 30 & 22 & 32 & 37 & 63 & 9 & 16 & 37 \\
\hline 35 Supermercados & 0 & 0 & 0 & 0 & 0 & 0 & 0 & 0 & 0 & 0 & 0 & 0 & 0 & 0 & 0 & 0 & 0 \\
\hline 36 Transportes & 89 & 18 & 7 & 46 & 38 & 15 & 22 & 19 & 13 & 14 & 19 & 11 & 25 & 21 & 6 & 16 & 83 \\
\hline 37 Comunicações & 1 & 2 & 2 & 5 & 5 & 2 & 5 & 10 & 4 & 5 & 3 & 3 & 4 & 10 & 1 & 2 & 7 \\
\hline 38 Instituições Financeiras & 9 & 5 & 5 & 4 & 8 & 3 & 4 & 4 & 4 & 4 & 5 & 4 & 2 & 6 & 1 & 4 & 11 \\
\hline 39 Serviços Prestados às Famílias & 16 & 6 & 5 & 8 & 8 & 2 & 5 & 11 & 4 & 4 & 5 & 3 & 7 & 9 & 2 & 4 & 6 \\
\hline 40 Serviços Prestados às Empresas & 27 & 11 & 37 & 5 & 6 & 2 & 5 & 9 & 7 & 8 & 7 & 5 & 4 & 14 & 2 & 3 & 10 \\
\hline 41 Aluguel de Imóveis & 0 & 2 & 1 & 3 & 1 & 1 & 3 & 3 & 2 & 2 & 1 & 1 & 2 & 5 & 0 & 0 & 2 \\
\hline 42 Administração Pública & 28 & 4 & 13 & 5 & 5 & 2 & 4 & 5 & 4 & 4 & 7 & 5 & 4 & 56 & 1 & 2 & 7 \\
\hline 43 Serviços Privados não-mercantis & 0 & 0 & 0 & 0 & 0 & 0 & 0 & 0 & 0 & 0 & 0 & 0 & 0 & 0 & 0 & 0 & 0 \\
\hline Produção nacional & 1551 & 195 & 187 & 531 & 959 & 373 & 681 & 726 & 456 & 391 & 524 & 614 & 437 & 729 & 229 & 396 & 1413 \\
\hline Importação & 29 & 8 & 8 & 16 & 62 & 44 & 21 & 28 & 21 & 87 & 22 & 41 & 7 & 34 & 19 & 24 & 411 \\
\hline Imposto de importação & 3 & 0 & 1 & 1 & 2 & 1 & 1 & 3 & 2 & 10 & 2 & 4 & 1 & 1 & 2 & 2 & 4 \\
\hline ICM nacional & 82 & 0 & 0 & 1 & 0 & 0 & 1 & 1 & 1 & 0 & 0 & 0 & 0 & 0 & 0 & 0 & 1 \\
\hline ICM importado & 1 & 0 & 0 & 0 & 0 & 0 & 0 & 0 & 0 & 0 & 0 & 0 & 0 & 0 & 0 & 0 & 0 \\
\hline IPI nacional & 12 & 1 & 2 & 2 & 1 & 0 & 1 & 1 & 1 & 1 & 1 & 1 & 1 & 1 & 0 & 0 & 2 \\
\hline IPI importado & 1 & 0 & 0 & 0 & 0 & 0 & 0 & 0 & 0 & 0 & 0 & 0 & 0 & 0 & 0 & 0 & 0 \\
\hline Outros impostos indiretos líquidos nacional & 27 & 10 & 8 & 12 & 17 & 9 & 11 & 12 & 10 & 9 & 12 & 11 & 5 & 15 & 5 & 10 & 37 \\
\hline Outros impostos indiretos líquidos importado & 1 & 1 & 0 & 0 & 1 & 1 & 0 & 1 & 0 & 1 & 0 & 1 & 0 & 1 & 1 & 1 & 2 \\
\hline Consumo intermediário & 1706 & 214 & 206 & 563 & 1041 & 429 & 716 & 772 & 491 & 498 & 562 & 673 & 451 & 782 & 256 & 433 & 1870 \\
\hline Remunerações & 402 & 65 & 42 & 118 & 69 & 33 & 261 & 285 & 114 & 95 & 58 & 149 & 120 & 171 & 36 & 55 & 110 \\
\hline Salários & 382 & 57 & 32 & 104 & 59 & 29 & 233 & 251 & 101 & 84 & 51 & 133 & 108 & 151 & 32 & 50 & 87 \\
\hline Contribuições sociais efetivas & 20 & 8 & 10 & 14 & 10 & 4 & 27 & 34 & 13 & 11 & 7 & 16 & 12 & 20 & 4 & 5 & 23 \\
\hline Previdência oficial/FGTS & 19 & 5 & 4 & 13 & 7 & 4 & 26 & 32 & 13 & 10 & 6 & 16 & 11 & 19 & 4 & 5 & 9 \\
\hline Previdência privada & 0 & 2 & 6 & 1 & 3 & 0 & 1 & 2 & 1 & 1 & 0 & 1 & 1 & 1 & 0 & 0 & 14 \\
\hline Contribuições sociais fictícias & 0 & 0 & 0 & 0 & 0 & 0 & 0 & 0 & 0 & 0 & 0 & 0 & 0 & 0 & 0 & 0 & 0 \\
\hline Excedente operacional bruto (EOB) & 1863 & 92 & 205 & 232 & 186 & 109 & 118 & 332 & 131 & 215 & 99 & 398 & 143 & 151 & 74 & 157 & 651 \\
\hline Rendimento de autônomos & 13 & 11 & 0 & 7 & 0 & 0 & 12 & 2 & 0 & 0 & 0 & 1 & 42 & 5 & 0 & 0 & 0 \\
\hline EOB Exclusive rendimento de autônomos & 1849 & 81 & 205 & 225 & 186 & 109 & 106 & 331 & 131 & 215 & 99 & 398 & 101 & 146 & 74 & 157 & 651 \\
\hline Valor adicionado a custo de fatores & 2265 & 157 & 247 & 350 & 256 & 142 & 378 & 617 & 246 & 310 & 157 & 547 & 263 & 322 & 110 & 212 & 761 \\
\hline Outros impostos sobre a produção & 0 & 5 & 5 & 11 & 13 & 6 & 16 & 20 & 10 & 10 & 8 & 12 & 9 & 14 & 4 & 7 & 24 \\
\hline Outros subsídios à produção & (-) 52 & 0 & 0 & 0 & $(-) 1$ & 0 & 0 & 0 & 0 & 0 & $(-) \quad 0 \quad(-)$ & 242 & 0 & $(-) 7$ & 0 & 0 & 0 \\
\hline Valor adicionado a preço básico & 2213 & 161 & 252 & 362 & 268 & 148 & 395 & 637 & 255 & 319 & 165 & 318 & 272 & 330 & 114 & 219 & 785 \\
\hline Valor da produção & 3919 & 375 & 458 & 925 & 1309 & 576 & 1111 & 1409 & 746 & 817 & 727 & 990 & 723 & 1112 & 370 & 653 & 2655 \\
\hline Pessoal ocupado & 15247 & 302 & 42 & 552 & 152 & 74 & 690 & 549 & 212 & 176 & 106 & 284 & 940 & 452 & 87 & 95 & 90 \\
\hline
\end{tabular}


ANEXO B - Matriz de insumo-produto do Brasil do ano de 1990, valores nominais em milhões de $\mathrm{Cr} \$$ (metodologia tradicional).

\begin{tabular}{|c|c|c|c|c|c|c|c|c|c|c|c|c|c|c|c|c|c|}
\hline Setores & 18 & 19 & 20 & 21 & 22 & 23 & 24 & 25 & 26 & 27 & 28 & 29 & 30 & 31 & 32 & 33 & 34 \\
\hline 1 Agropecuária & 4 & 1 & 0 & 52 & 0 & 4 & 95 & 350 & 493 & 165 & 79 & 160 & 110 & 1 & 1 & 1 & 0 \\
\hline 2 Extrativa Mineral & 6 & 1 & 0 & 0 & 0 & 0 & 0 & 0 & 0 & 0 & 0 & 0 & 7 & 15 & 0 & 24 & 0 \\
\hline 3 Petróleo e gás & 1 & 0 & 0 & 0 & 0 & 0 & 0 & 0 & 0 & 0 & 0 & 0 & 0 & 0 & 3 & 0 & 0 \\
\hline 4 Minerais não-metálicos & 4 & 10 & 1 & 0 & 0 & 0 & 1 & 7 & 0 & 0 & 1 & 0 & 19 & 7 & 0 & 469 & 0 \\
\hline 5 Siderurgia & 9 & 1 & 1 & 1 & 1 & 1 & 0 & 1 & 0 & 0 & 0 & 0 & 2 & 4 & 1 & 26 & 0 \\
\hline 6 Metalurgia de não-ferrosos & 4 & 1 & 2 & 1 & 0 & 0 & 0 & 1 & 0 & 2 & 0 & 0 & 1 & 11 & 0 & 18 & 0 \\
\hline 7 Outros Produtos Metalúrgicos & 10 & 5 & 2 & 5 & 3 & 3 & 1 & 13 & 6 & 5 & 2 & 15 & 19 & 8 & 2 & 249 & 4 \\
\hline 8 Máquinas e Equipamentos & 8 & 4 & 6 & 18 & 2 & 3 & 1 & 7 & 4 & 2 & 13 & 4 & 10 & 4 & 52 & 50 & 13 \\
\hline 9 Material Elétrico & 1 & 0 & 0 & 1 & 0 & 0 & 0 & 0 & 0 & 0 & 0 & 0 & 0 & 3 & 35 & 162 & 2 \\
\hline 10 Equipamentos Eletrônicos & 0 & 0 & 0 & 1 & 0 & 0 & 0 & 0 & 0 & 0 & 0 & 0 & 1 & 1 & 1 & 2 & 0 \\
\hline 11 Automóveis, caminhões e ônibus & 1 & 0 & 0 & 1 & 1 & 0 & 0 & 0 & 0 & 0 & 0 & 0 & 1 & 1 & 4 & 2 & 1 \\
\hline 12 Peças e outros veículos & 0 & 0 & 0 & 1 & 0 & 0 & 0 & 0 & 0 & 0 & 0 & 0 & 0 & 1 & 1 & 7 & 0 \\
\hline 13 Madeira e Mobiliário & 3 & 0 & 1 & 1 & 1 & 3 & 0 & 1 & 1 & 0 & 0 & 0 & 3 & 5 & 0 & 126 & 5 \\
\hline 14 Celulose, Papel e Gráfica & 8 & 20 & 9 & 8 & 6 & 11 & 2 & 19 & 5 & 4 & 3 & 5 & 35 & 10 & 6 & 5 & 66 \\
\hline 15 Indústria da Borracha & 2 & 1 & 1 & 4 & 1 & 22 & 0 & 1 & 0 & 0 & 1 & 0 & 1 & 2 & 1 & 11 & 0 \\
\hline 16 Elementos Químicos & 73 & 23 & 2 & 4 & 0 & 2 & 0 & 1 & 0 & 0 & 2 & 1 & 9 & 2 & 1 & 4 & 131 \\
\hline 17 Refino de Petróleo & 117 & 25 & 143 & 86 & 7 & 16 & 2 & 13 & 5 & 4 & 4 & 8 & 21 & 17 & 28 & 63 & 470 \\
\hline 18 Químicos Diversos & 138 & 23 & 14 & 24 & 1 & 13 & 0 & 2 & 1 & 1 & 2 & 3 & 17 & 7 & 2 & 48 & 0 \\
\hline 19 Farmacêuticos e Veterinários & 5 & 12 & 0 & 1 & 0 & 0 & 0 & 0 & 0 & 0 & 0 & 0 & 6 & 0 & 0 & 0 & 0 \\
\hline 20 Artigos Plásticos & 11 & 13 & 31 & 9 & 5 & 21 & 1 & 7 & 9 & 9 & 1 & 3 & 15 & 10 & 1 & 90 & 22 \\
\hline 21 Indústria Têxtil & 2 & 1 & 6 & 494 & 322 & 9 & 1 & 5 & 1 & 0 & 10 & 12 & 2 & 7 & 1 & 2 & 4 \\
\hline 22 Artigos do Vestuário & 0 & 0 & 0 & 1 & 3 & 1 & 0 & 0 & 0 & 0 & 1 & 0 & 1 & 0 & 0 & 2 & 0 \\
\hline 23 Calçados & 1 & 0 & 0 & 1 & 7 & 83 & 0 & 0 & 1 & 0 & 0 & 0 & 1 & 1 & 0 & 1 & 0 \\
\hline 24 Indústria do Café & 0 & 0 & 0 & 0 & 0 & 0 & 54 & 0 & 0 & 0 & 0 & 0 & 0 & 0 & 0 & 0 & 0 \\
\hline 25 Beneficiamento de Produtos Vegetais & 2 & 1 & 0 & 1 & 0 & 0 & 0 & 32 & 2 & 3 & 0 & 12 & 142 & 0 & 0 & 0 & 0 \\
\hline 26 Abate de Animais & 0 & 2 & 0 & 0 & 0 & 35 & 0 & 1 & 85 & 0 & 0 & 5 & 11 & 0 & 0 & 0 & 0 \\
\hline 27 Indústria de Laticínios & 0 & 0 & 0 & 0 & 0 & 0 & 0 & 1 & 0 & 96 & 0 & 0 & 7 & 0 & 0 & 0 & 0 \\
\hline 28 Fabricação de Açúcar & 1 & 1 & 0 & 0 & 0 & 0 & 0 & 6 & 0 & 2 & 40 & 0 & 32 & 0 & 1 & 0 & 1 \\
\hline 29 Fabricação de Óleos Vegetais & 9 & 24 & 0 & 1 & 0 & 0 & 0 & 3 & 0 & 1 & 0 & 98 & 63 & 0 & 0 & 0 & 0 \\
\hline 30 Outros Produtos Alimentares & 1 & 1 & 0 & 1 & 0 & 0 & 0 & 2 & 4 & 1 & 0 & 1 & 54 & 1 & 0 & 0 & 2 \\
\hline 31 Indústrias Diversas & 6 & 3 & 2 & 6 & 8 & 5 & 0 & 3 & 2 & 1 & 3 & 2 & 3 & 8 & 6 & 8 & 1 \\
\hline 32 Serviços Industriais de Utilidade Pública & 5 & 4 & 9 & 23 & 5 & 6 & 1 & 11 & 8 & 4 & 6 & 6 & 22 & 3 & 340 & 8 & 60 \\
\hline 33 Construção Civil & 1 & 1 & 1 & 1 & 1 & 1 & 0 & 1 & 1 & 1 & 1 & 1 & 2 & 1 & 10 & 211 & 8 \\
\hline 34 Comércio & 26 & 33 & 13 & 54 & 30 & 16 & 6 & 58 & 35 & 8 & 8 & 25 & 72 & 18 & 14 & 225 & 89 \\
\hline 35 Supermercados & 0 & 0 & 0 & 0 & 0 & 0 & 0 & 0 & 0 & 0 & 0 & 0 & 0 & 0 & 0 & 0 & 0 \\
\hline 36 Transportes & 23 & 17 & 6 & 16 & 6 & 9 & 4 & 24 & 28 & 9 & 7 & 30 & 35 & 8 & 10 & 79 & 166 \\
\hline 37 Comunicações & 4 & 3 & 2 & 4 & 3 & 2 & 1 & 3 & 3 & 1 & 1 & 2 & 5 & 2 & 6 & 7 & 42 \\
\hline 38 Instituições Financeiras & 5 & 0 & 1 & 5 & 1 & 1 & 1 & 3 & 3 & 1 & 1 & 3 & 4 & 2 & 28 & 8 & 39 \\
\hline 39 Serviços Prestados às Famílias & 3 & 2 & 2 & 6 & 4 & 2 & 1 & 5 & 4 & 3 & 3 & 2 & 7 & 2 & 24 & 26 & 77 \\
\hline 40 Serviços Prestados às Empresas & 4 & 15 & 3 & 5 & 6 & 3 & 2 & 8 & 5 & 3 & 2 & 3 & 15 & 24 & 44 & 49 & 147 \\
\hline 41 Aluguel de Imóveis & 1 & 2 & 1 & 2 & 3 & 1 & 0 & 1 & 1 & 0 & 0 & 1 & 5 & 1 & 5 & 5 & 85 \\
\hline 42 Administração Pública & 8 & 9 & 3 & 4 & 3 & 3 & 1 & 10 & 3 & 2 & 1 & 2 & 13 & 10 & 15 & 17 & 59 \\
\hline 43 Serviços Privados não-mercantis & 0 & 0 & 0 & 0 & 0 & 0 & 0 & 0 & 0 & 0 & 0 & 0 & 0 & 0 & 0 & 0 & 0 \\
\hline Produção nacional & 505 & 261 & 264 & 844 & 432 & 278 & 177 & 601 & 713 & 328 & 194 & 407 & 772 & 201 & 645 & 2007 & 1498 \\
\hline Importação & 81 & 46 & 10 & 38 & 6 & 17 & 0 & 40 & 5 & 4 & 3 & 5 & 37 & 6 & 78 & 45 & 28 \\
\hline Imposto de importação & 4 & 4 & 1 & 2 & 1 & 1 & 0 & 4 & 0 & 0 & 0 & 0 & 3 & 0 & 1 & 5 & 0 \\
\hline ICM nacional & 1 & 1 & 1 & 1 & 0 & 1 & 0 & 1 & 0 & 0 & 0 & 0 & 3 & 1 & 42 & 325 & 49 \\
\hline ICM importado & 0 & 0 & 0 & 0 & 0 & 0 & 0 & 0 & 0 & 0 & 0 & 0 & 0 & 0 & 1 & 6 & 1 \\
\hline IPI nacional & 1 & 2 & 1 & 1 & 1 & 1 & 0 & 2 & 1 & 0 & 0 & 1 & 3 & 2 & 10 & 149 & 16 \\
\hline IPI importado & 0 & 0 & 0 & 0 & 0 & 0 & 0 & 0 & 0 & 0 & 0 & 0 & 0 & 0 & 1 & 5 & 1 \\
\hline Outros impostos indiretos líquidos nacional & 16 & 5 & 5 & 14 & 4 & 4 & 3 & 8 & 6 & 3 & 3 & 7 & 13 & 5 & 23 & 24 & 83 \\
\hline Outros impostos indiretos líquidos importado & 1 & 1 & 0 & 1 & 0 & 0 & 0 & 1 & 0 & 0 & 0 & 1 & 1 & 0 & 2 & 1 & 4 \\
\hline Consumo intermediário & 609 & 320 & 282 & 901 & 444 & 302 & 182 & 657 & 726 & 336 & 201 & 421 & 832 & 214 & 803 & 2567 & 1679 \\
\hline Remunerações & 126 & 57 & 77 & 108 & 114 & 77 & 15 & 69 & 55 & 21 & 22 & 15 & 131 & 63 & 396 & 614 & 1133 \\
\hline Salários & 113 & 51 & 69 & 95 & 103 & 68 & 13 & 61 & 49 & 18 & 20 & 14 & 116 & 57 & 339 & 552 & 1011 \\
\hline Contribuições sociais efetivas & 13 & 6 & 9 & 13 & 11 & 9 & 1 & 8 & 5 & 2 & 2 & 2 & 15 & 7 & 57 & 62 & 122 \\
\hline Previdência oficial/FGTS & 12 & 6 & 8 & 12 & 10 & 8 & 1 & 8 & 5 & 2 & 2 & 2 & 14 & 6 & 37 & 59 & 116 \\
\hline Previdência privada & 1 & 0 & 0 & 1 & 1 & 0 & 0 & 0 & 0 & 0 & 0 & 0 & 1 & 0 & 21 & 3 & 7 \\
\hline Contribuições sociais fictícias & 0 & 0 & 0 & 0 & 0 & 0 & 0 & 0 & 0 & 0 & 0 & 0 & 0 & 0 & 0 & 0 & 0 \\
\hline Excedente operacional bruto (EOB) & 203 & 137 & 135 & 315 & 172 & 45 & 35 & 136 & 74 & 47 & 39 & 58 & 146 & 125 & 305 & 1456 & 1659 \\
\hline Rendimento de autônomos & 0 & 1 & 0 & 1 & 114 & 2 & 0 & 1 & 1 & 0 & 0 & 0 & 2 & 7 & 0 & 230 & 659 \\
\hline EOB Exclusive rendimento de autônomos & 202 & 136 & 135 & 314 & 58 & 43 & 35 & 135 & 74 & 47 & 39 & 58 & 144 & 118 & 305 & 1226 & 1000 \\
\hline Valor adicionado a custo de fatores & 329 & 194 & 213 & 423 & 286 & 122 & 50 & 206 & 129 & 68 & 61 & 74 & 277 & 188 & 702 & 2070 & 2791 \\
\hline Outros impostos sobre a produção & 11 & 6 & 6 & 14 & 9 & 6 & 2 & 9 & 8 & 4 & 3 & 5 & 13 & 5 & 29 & 55 & 70 \\
\hline Outros subsídios à produção & 0 & 0 & 0 & $(-) 9$ & 0 & $(-) 6$ & (-) 5 & 0 & 0 & 0 & 0 & 0 & 0 & 0 & $(-) 1$ & 0 & $(-) 13$ \\
\hline Valor adicionado a preço básico & 340 & 200 & 219 & 428 & 295 & 121 & 47 & 215 & 137 & 71 & 64 & 78 & 290 & 193 & 730 & 2125 & 2848 \\
\hline Valor da produção & 949 & 520 & 501 & 1329 & 738 & 423 & 228 & 872 & 863 & 407 & 265 & 499 & 1122 & 408 & 1533 & 4692 & 4527 \\
\hline Pessoal ocupado & 195 & 123 & 196 & 427 & 1757 & 418 & 63 & 318 & 237 & 69 & 74 & 51 & 610 & 268 & 341 & 4061 & 7318 \\
\hline
\end{tabular}


ANEXO B - Matriz de insumo-produto do Brasil do ano de 1990, valores nominais em milhões de $\mathrm{Cr} \$$ (metodologia tradicional).

\begin{tabular}{|c|c|c|c|c|c|c|c|c|c|c|c|}
\hline Setores & 35 & 36 & 37 & 38 & 39 & 40 & 41 & 42 & 43 & 44 & $\begin{array}{c}\text { Total } \\
\text { da atividade }\end{array}$ \\
\hline 1 Agropecuária & 0 & 1 & 0 & 0 & 65 & 0 & 0 & 60 & 2 & 0 & 2475 \\
\hline 2 Extrativa Mineral & 0 & 0 & 0 & 0 & 0 & 0 & 0 & 1 & 0 & 0 & 219 \\
\hline 3 Petróleo e gás & 0 & 0 & 0 & 1 & 0 & 0 & 0 & 1 & 0 & 0 & 432 \\
\hline 4 Minerais não-metálicos & 0 & 0 & 0 & 0 & 13 & 0 & 0 & 8 & 0 & 0 & 843 \\
\hline 5 Siderurgia & 0 & 0 & 0 & 1 & 2 & 1 & 0 & 2 & 0 & 0 & 1084 \\
\hline 6 Metalurgia de não-ferrosos & 0 & 0 & 0 & 0 & 2 & 0 & 0 & 1 & 0 & 0 & 467 \\
\hline 7 Outros Produtos Metalúrgicos & 0 & 7 & 2 & 1 & 13 & 1 & 0 & 2 & 0 & 0 & 981 \\
\hline 8 Máquinas e Equipamentos & 1 & 8 & 3 & 2 & 11 & 6 & 4 & 13 & 0 & 0 & 821 \\
\hline 9 Material Elétrico & 0 & 1 & 5 & 0 & 11 & 2 & 1 & 6 & 0 & 0 & 424 \\
\hline 10 Equipamentos Eletrônicos & 0 & 1 & 8 & 0 & 12 & 3 & 0 & 4 & 0 & 0 & 230 \\
\hline 11 Automóveis, caminhões e ônibus & 0 & 2 & 0 & 1 & 8 & 1 & 0 & 4 & 0 & 0 & 71 \\
\hline 12 Peças e outros veículos & 0 & 100 & 1 & 1 & 113 & 0 & 0 & 18 & 0 & 0 & 711 \\
\hline 13 Madeira e Mobiliário & 0 & 2 & 0 & 0 & 8 & 0 & 0 & 4 & 0 & 0 & 336 \\
\hline 14 Celulose, Papel e Gráfica & 11 & 8 & 3 & 20 & 17 & 109 & 1 & 85 & 1 & 0 & 874 \\
\hline 15 Indústria da Borracha & 0 & 46 & 0 & 0 & 62 & 0 & 0 & 2 & 0 & 0 & 342 \\
\hline 16 Elementos Químicos & 0 & 5 & 1 & 0 & 14 & 0 & 0 & 14 & 0 & 0 & 443 \\
\hline 17 Refino de Petróleo & 0 & 269 & 0 & 4 & 15 & 7 & 0 & 22 & 1 & 0 & 2394 \\
\hline 18 Químicos Diversos & 0 & 2 & 0 & 0 & 16 & 0 & 0 & 14 & 0 & 0 & 882 \\
\hline 19 Farmacêuticos e Veterinários & 0 & 0 & 0 & 0 & 31 & 0 & 0 & 24 & 0 & 0 & 105 \\
\hline 20 Artigos Plásticos & 4 & 31 & 2 & 0 & 17 & 1 & 2 & 10 & 1 & 0 & 458 \\
\hline 21 Indústria Têxtil & 1 & 13 & 0 & 1 & 57 & 0 & 0 & 10 & 0 & 0 & 1024 \\
\hline 22 Artigos do Vestuário & 0 & 0 & 0 & 0 & 1 & 0 & 0 & 2 & 0 & 0 & 31 \\
\hline 23 Calçados & 0 & 0 & 0 & 0 & 3 & 0 & 0 & 1 & 0 & 0 & 112 \\
\hline 24 Indústria do Café & 0 & 0 & 0 & 0 & 11 & 0 & 0 & 1 & 0 & 0 & 68 \\
\hline 25 Beneficiamento de Produtos Vegetais & 0 & 0 & 0 & 0 & 24 & 0 & 0 & 9 & 1 & 0 & 242 \\
\hline 26 Abate de Animais & 0 & 0 & 0 & 0 & 56 & 0 & 0 & 13 & 3 & 0 & 216 \\
\hline 27 Indústria de Laticínios & 0 & 0 & 0 & 0 & 14 & 0 & 0 & 16 & 1 & 0 & 138 \\
\hline 28 Fabricação de Açúcar & 0 & 0 & 0 & 0 & 22 & 0 & 0 & 1 & 1 & 0 & 140 \\
\hline 29 Fabricação de Óleos Vegetais & 0 & 0 & 0 & 0 & 9 & 0 & 0 & 0 & 0 & 0 & 253 \\
\hline 30 Outros Produtos Alimentares & 0 & 10 & 0 & 0 & 141 & 0 & 0 & 7 & 2 & 0 & 380 \\
\hline 31 Indústrias Diversas & 0 & 1 & 0 & 13 & 5 & 9 & 0 & 21 & 1 & 0 & 291 \\
\hline 32 Serviços Industriais de Utilidade Pública & 4 & 10 & 4 & 17 & 64 & 12 & 9 & 104 & 3 & 0 & 1089 \\
\hline 33 Construção Civil & 3 & 11 & 3 & 0 & 14 & 4 & 155 & 36 & 1 & 0 & 496 \\
\hline 34 Comércio & 4 & 98 & 4 & 17 & 275 & 18 & 1 & 168 & 2 & 0 & 1875 \\
\hline 35 Supermercados & 0 & 0 & 0 & 0 & 12 & 0 & 0 & 0 & 0 & 0 & 12 \\
\hline 36 Transportes & 6 & 124 & 9 & 31 & 35 & 16 & 0 & 58 & 1 & 0 & 1220 \\
\hline 37 Comunicações & 3 & 16 & 0 & 50 & 16 & 16 & 1 & 44 & 1 & 0 & 306 \\
\hline 38 Instituições Financeiras & 3 & 32 & 3 & 154 & 9 & 6 & 3 & 22 & 0 & 4599 & 5021 \\
\hline 39 Serviços Prestados às Famílias & 6 & 38 & 8 & 105 & 45 & 17 & 1 & 310 & 2 & 0 & 808 \\
\hline 40 Serviços Prestados às Empresas & 18 & 36 & 17 & 162 & 39 & 56 & 2 & 370 & 1 & 0 & 1202 \\
\hline 41 Aluguel de Imóveis & 12 & 9 & 3 & 44 & 9 & 8 & 1 & 34 & 3 & 0 & 266 \\
\hline 42 Administração Pública & 8 & 15 & 6 & 56 & 21 & 37 & 1 & 136 & 1 & 0 & 599 \\
\hline 43 Serviços Privados não-mercantis & 0 & 0 & 0 & 0 & 0 & 0 & 0 & 0 & 0 & 0 & 0 \\
\hline Produção nacional & 84 & 898 & 85 & 684 & 1311 & 332 & 184 & 1658 & 27 & 4599 & 30382 \\
\hline Importação & 2 & 191 & 8 & 16 & 37 & 7 & 1 & 48 & 0 & 0 & 1642 \\
\hline Imposto de importação & 0 & 3 & 0 & 0 & 3 & 0 & 0 & 2 & 0 & 0 & 78 \\
\hline ICM nacional & 3 & 68 & 4 & 18 & 183 & 18 & 2 & 67 & 2 & 0 & 879 \\
\hline ICM importado & 0 & 8 & 1 & 0 & 4 & 0 & 0 & 2 & 0 & 0 & 23 \\
\hline IPI nacional & 2 & 26 & 3 & 11 & 76 & 10 & 1 & 35 & 1 & 5 & 385 \\
\hline IPI importado & 0 & 3 & 0 & 0 & 2 & 0 & 0 & 2 & 0 & 0 & 15 \\
\hline Outros impostos indiretos líquidos nacional & 3 & 26 & 5 & 47 & 23 & 9 & 5 & 16 & 0 & 74 & 654 \\
\hline Outros impostos indiretos líquidos importado & 0 & 2 & 1 & 1 & 1 & 0 & 0 & 1 & 0 & 0 & 34 \\
\hline Consumo intermediário & 94 & 1225 & 107 & 777 & 1640 & 377 & 193 & 1831 & 31 & 4678 & 34092 \\
\hline Remunerações & 79 & 508 & 189 & 1605 & 931 & 365 & 65 & 5037 & 313 & 0 & 14369 \\
\hline Salários & 70 & 445 & 157 & 1404 & 835 & 324 & 58 & 3233 & 296 & 0 & 11516 \\
\hline Contribuições sociais efetivas & 9 & 64 & 33 & 201 & 96 & 41 & 6 & 458 & 17 & 0 & 1507 \\
\hline Previdência oficial/FGTS & 8 & 53 & 20 & 118 & 91 & 39 & 6 & 453 & 17 & 0 & 1317 \\
\hline Previdência privada & 0 & 11 & 12 & 83 & 5 & 2 & 0 & 5 & 0 & 0 & 190 \\
\hline Contribuições sociais fictícias & 0 & 0 & 0 & 0 & 0 & 0 & 0 & 1346 & 0 & 0 & 1346 \\
\hline Excedente operacional bruto (EOB) & 58 & 616 & 185 & 3073 & 860 & 542 & 1674 & 0 & 6 & (-) 4678 & 12579 \\
\hline Rendimento de autônomos & 27 & 254 & 0 & 58 & 629 & 166 & 20 & 0 & 0 & 0 & 2265 \\
\hline EOB Exclusive rendimento de autônomos & 32 & 362 & 185 & 3015 & 231 & 376 & 1654 & 0 & 6 & (-) 4678 & 10315 \\
\hline Valor adicionado a custo de fatores & 137 & 1124 & 374 & 4678 & 1791 & 907 & 1739 & 5037 & 320 & (-) 4678 & 26949 \\
\hline Outros impostos sobre a produção & 4 & 34 & 7 & 151 & 54 & 22 & 11 & 58 & 5 & 0 & 776 \\
\hline Outros subsídios à produção & 0 & $(-) 72$ & $(-) 2$ & 0 & $(-) 0$ & 0 & 0 & 0 & 0 & 0 & $(-) 411$ \\
\hline Valor adicionado a preço básico & 141 & 1086 & 378 & 4829 & 1846 & 929 & 1750 & 5095 & 325 & (-) 4678 & 27314 \\
\hline Valor da produção & 235 & 2310 & 485 & 5606 & 3485 & 1305 & 1944 & 6926 & 356 & 0 & 61406 \\
\hline Pessoal ocupado & 460 & 2021 & 240 & 1107 & 7476 & 1324 & 264 & 5899 & 4000 & 0 & 59362 \\
\hline
\end{tabular}


ANEXO B - Matriz de insumo-produto do Brasil do ano de 1990, valores nominais em milhões de $\mathrm{Cr} \$$ (metodologia tradicional).

\begin{tabular}{|c|c|c|c|c|c|c|c|}
\hline Setores & $\begin{array}{l}\text { Formação bruta } \\
\text { de capital fixo }\end{array}$ & $\begin{array}{c}\text { Exportação } \\
\text { de bens e serviços }\end{array}$ & $\begin{array}{c}\text { Variação } \\
\text { de estoque }\end{array}$ & $\begin{array}{l}\text { Consumo do } \\
\text { Governo }\end{array}$ & $\begin{array}{c}\text { Consumo } \\
\text { das famílias }\end{array}$ & $\begin{array}{c}\text { Demanda } \\
\text { final }\end{array}$ & $\begin{array}{c}\text { Demanda } \\
\text { total }\end{array}$ \\
\hline 1 Agropecuária & 87 & 87 & 180 & 0 & 1089 & 1444 & 3919 \\
\hline 2 Extrativa Mineral & 0 & 160 & $(-) 7$ & 0 & 3 & 156 & 375 \\
\hline 3 Petróleo e gás & 1 & 1 & 20 & 0 & 5 & 26 & 458 \\
\hline 4 Minerais não-metálicos & 1 & 26 & 5 & 0 & 50 & 82 & 925 \\
\hline 5 Siderurgia & 2 & 221 & (-) 9 & 0 & 12 & 225 & 1309 \\
\hline 6 Metalurgia de não-ferrosos & 1 & 110 & $(-) 14$ & 0 & 13 & 109 & 576 \\
\hline 7 Outros Produtos Metalúrgicos & 20 & 38 & $(-) 10$ & 0 & 82 & 130 & 1111 \\
\hline 8 Máquinas e Equipamentos & 475 & 94 & $(-) \quad 29$ & 0 & 48 & 588 & 1409 \\
\hline 9 Material Elétrico & 103 & 54 & (-) 23 & 0 & 189 & 322 & 746 \\
\hline 10 Equipamentos Eletrônicos & 251 & 45 & $(-) 9$ & 0 & 299 & 587 & 817 \\
\hline 11 Automóveis, caminhões e ônibus & 273 & 68 & $(-) 51$ & 0 & 366 & 656 & 727 \\
\hline 12 Peças e outros veículos & 86 & 149 & $(-) 21$ & 0 & 66 & 280 & 990 \\
\hline 13 Madeira e Mobiliário & 89 & 28 & $(-) 4$ & 0 & 274 & 387 & 723 \\
\hline 14 Celulose, Papel e Gráfica & 4 & 67 & 2 & 0 & 165 & 238 & 1112 \\
\hline 15 Indústria da Borracha & 0 & 20 & 1 & 0 & 7 & 28 & 370 \\
\hline 16 Elementos Químicos & 1 & 30 & (-) 21 & 0 & 200 & 210 & 653 \\
\hline 17 Refino de Petróleo & 4 & 138 & 8 & 0 & 112 & 261 & 2655 \\
\hline 18 Químicos Diversos & 1 & 23 & $(-) 13$ & 0 & 55 & 66 & 949 \\
\hline 19 Farmacêuticos e Veterinários & 0 & 9 & $(-) 11$ & 0 & 416 & 415 & 520 \\
\hline 20 Artigos Plásticos & 1 & 8 & $(-) 14$ & 0 & 49 & 43 & 501 \\
\hline 21 Indústria Têxtil & 1 & 70 & 9 & 0 & 226 & 305 & 1329 \\
\hline 22 Artigos do Vestuário & 0 & 10 & $(-) 20$ & 0 & 717 & 707 & 738 \\
\hline 23 Calçados & 0 & 98 & $(-) 7$ & 0 & 220 & 311 & 423 \\
\hline 24 Indústria do Café & 0 & 67 & 21 & 0 & 72 & 160 & 228 \\
\hline 25 Beneficiamento de Produtos Vegetais & 1 & 118 & 5 & 0 & 506 & 630 & 872 \\
\hline 26 Abate de Animais & 0 & 35 & 7 & 0 & 604 & 647 & 863 \\
\hline 27 Indústria de Laticínios & 0 & 1 & $(-) 1$ & 0 & 269 & 269 & 407 \\
\hline 28 Fabricação de Açúcar & 0 & 32 & $(-) 9$ & 0 & 101 & 125 & 265 \\
\hline 29 Fabricação de Óleos Vegetais & 0 & 130 & $(-) 3$ & 0 & 119 & 246 & 499 \\
\hline 30 Outros Produtos Alimentares & 0 & 34 & $(-) 10$ & 0 & 718 & 742 & 1122 \\
\hline 31 Indústrias Diversas & 13 & 13 & $(-) 7$ & 0 & 98 & 117 & 407 \\
\hline 32 Serviços Industriais de Utilidade Pública & 1 & 0 & 0 & 0 & 444 & 444 & 1533 \\
\hline 33 Construção Civil & 4195 & 0 & $(-) 0$ & 0 & 1 & 4196 & 4692 \\
\hline 34 Comércio & 198 & 71 & $(-) 35$ & 0 & 2417 & 2652 & 4527 \\
\hline 35 Supermercados & 0 & 0 & 0 & 0 & 223 & 223 & 235 \\
\hline 36 Transportes & 23 & 289 & $(-) 4$ & 0 & 782 & 1090 & 2310 \\
\hline 37 Comunicações & 0 & 7 & $(-) 0$ & 0 & 172 & 180 & 485 \\
\hline 38 Instituições Financeiras & 0 & 4 & 0 & 0 & 581 & 585 & 5606 \\
\hline 39 Serviços Prestados às Famílias & 1 & 95 & $(-) 1$ & 0 & 2583 & 2678 & 3485 \\
\hline 40 Serviços Prestados às Empresas & 61 & 9 & $(-) 0$ & 0 & 33 & 103 & 1305 \\
\hline 41 Aluguel de Imóveis & 0 & 0 & 0 & 0 & 1677 & 1677 & 1944 \\
\hline 42 Administração Pública & 23 & 19 & $(-) 1$ & 6127 & 159 & 6326 & 6926 \\
\hline 43 Serviços Privados não-mercantis & 0 & 0 & 0 & 0 & 356 & 356 & 356 \\
\hline Produção nacional & 5920 & 2477 & $(-) 76$ & 6127 & 16576 & 31024 & 61406 \\
\hline Importação & 255 & 11 & $(-) 4$ & 0 & 306 & 568 & 2210 \\
\hline Imposto de importação & 32 & 1 & $(-) 3$ & 0 & 15 & 46 & 123 \\
\hline ICM nacional & 187 & 45 & $(-) 43$ & 0 & 1279 & 1468 & 2347 \\
\hline ICM importado & 23 & 0 & $(-) 1$ & 0 & 22 & 44 & 66 \\
\hline IPI nacional & 109 & 26 & (-) 27 & 0 & 383 & 491 & 876 \\
\hline IPI importado & 19 & 0 & $(-) 1$ & 0 & 8 & 26 & 41 \\
\hline Outros impostos indiretos líquidos nacional & 15 & 43 & $(-) 1$ & 0 & 237 & 293 & 947 \\
\hline Outros impostos indiretos líquidos importado & 2 & 0 & $(-) 0$ & 0 & 8 & 10 & 44 \\
\hline Consumo intermediário & 6563 & 2604 & $(-) 158$ & 6127 & 18834 & 33969 & 68062 \\
\hline Remuneraçōes & 0 & 0 & 0 & 0 & 0 & 0 & 14369 \\
\hline Salários & 0 & 0 & 0 & 0 & 0 & 0 & 11516 \\
\hline Contribuições sociais efetivas & 0 & 0 & 0 & 0 & 0 & 0 & 1507 \\
\hline Previdência oficial/FGTS & 0 & 0 & 0 & 0 & 0 & 0 & 1317 \\
\hline Previdência privada & 0 & 0 & 0 & 0 & 0 & 0 & 190 \\
\hline Contribuições sociais fictícias & 0 & 0 & 0 & 0 & 0 & 0 & 1346 \\
\hline Excedente operacional bruto (EOB) & 0 & 0 & 0 & 0 & 0 & 0 & 12579 \\
\hline Rendimento de autônomos & 0 & 0 & 0 & 0 & 0 & 0 & 2265 \\
\hline EOB Exclusive rendimento de autônomos & 0 & 0 & 0 & 0 & 0 & 0 & 10315 \\
\hline Valor adicionado a custo de fatores & 0 & 0 & 0 & 0 & 0 & 0 & 26949 \\
\hline Outros impostos sobre a produção & 0 & 0 & 0 & 0 & 0 & 0 & 776 \\
\hline Outros subsídios à produção & 0 & 0 & 0 & 0 & 0 & 0 & $(-) 411$ \\
\hline Valor adicionado a preço básico & 0 & 0 & 0 & 0 & 0 & 0 & 27314 \\
\hline Valor da produção & 0 & 0 & 0 & 0 & 0 & 0 & 61406 \\
\hline Pessoal ocupado & 0 & 0 & 0 & 0 & 0 & 0 & 0 \\
\hline
\end{tabular}


ANEXO C - Matriz de insumo-produto do ano de 1995, valores nominais em milhões de $\mathrm{R} \$$ (metodologia tradicional).

\begin{tabular}{|c|c|c|c|c|c|c|c|c|c|c|c|c|c|}
\hline Setores & 1 & 2 & 3 & 4 & 5 & 6 & 7 & 8 & 9 & 10 & 11 & 12 & 13 \\
\hline 1 Agropecuária & 12191 & 10 & 0 & 96 & 758 & 13 & 5 & 0 & 0 & 1 & 0 & 0 & 1771 \\
\hline 2 Extrativa Mineral & 220 & 542 & 5 & 530 & 642 & 342 & 59 & 0 & 24 & 27 & 1 & 0 & 0 \\
\hline 3 Petróleo e gás & 1 & 0 & 11 & 15 & 106 & 1 & 13 & 0 & 0 & 0 & 0 & 0 & 0 \\
\hline 4 Minerais não-metálicos & 70 & 90 & 44 & 3090 & 184 & 116 & 172 & 135 & 273 & 199 & 160 & 107 & 61 \\
\hline 5 Siderurgia & 4 & 4 & 25 & 202 & 8744 & 59 & 4900 & 1222 & 458 & 118 & 793 & 905 & 54 \\
\hline 6 Metalurgia de não-ferrosos & 2 & 2 & 14 & 2 & 180 & 2335 & 853 & 368 & 1228 & 207 & 112 & 640 & 42 \\
\hline 7 Outros Produtos Metalúrgicos & 119 & 232 & 189 & 162 & 520 & 188 & 1787 & 2171 & 797 & 425 & 659 & 2377 & 249 \\
\hline 8 Máquinas e Equipamentos & 195 & 359 & 196 & 281 & 685 & 207 & 512 & 679 & 730 & 229 & 519 & 867 & 84 \\
\hline 9 Material Elétrico & 9 & 14 & 6 & 13 & 65 & 19 & 58 & 492 & 1321 & 550 & 68 & 148 & 7 \\
\hline 10 Equipamentos Eletrônicos & 5 & 14 & 4 & 20 & 33 & 7 & 16 & 97 & 89 & 988 & 14 & 43 & 5 \\
\hline 11 Automóveis, caminhões e ônibus & 4 & 4 & 3 & 5 & 10 & 5 & 15 & 30 & 9 & 4 & 278 & 117 & 3 \\
\hline 12 Peças e outros veículos & 12 & 12 & 5 & 7 & 18 & 21 & 36 & 357 & 45 & 19 & 4359 & 3088 & 16 \\
\hline 13 Madeira e Mobiliário & 85 & 9 & 5 & 18 & 26 & 22 & 57 & 59 & 56 & 237 & 92 & 111 & 1603 \\
\hline 14 Celulose, Papel e Gráfica & 39 & 33 & 51 & 252 & 66 & 48 & 170 & 105 & 159 & 129 & 59 & 103 & 81 \\
\hline 15 Indústria da Borracha & 3 & 35 & 6 & 43 & 89 & 12 & 55 & 195 & 52 & 21 & 852 & 183 & 42 \\
\hline 16 Elementos Químicos & 129 & 15 & 1 & 163 & 126 & 324 & 65 & 26 & 44 & 14 & 22 & 24 & 20 \\
\hline 17 Refino de Petróleo & 1783 & 332 & 59 & 754 & 341 & 99 & 273 & 199 & 363 & 91 & 130 & 276 & 282 \\
\hline 18 Químicos Diversos & 4965 & 161 & 38 & 253 & 144 & 221 & 212 & 128 & 159 & 39 & 288 & 119 & 303 \\
\hline 19 Farmacêuticos e Veterinários & 236 & 4 & 1 & 3 & 3 & 7 & 2 & 1 & 1 & 1 & 1 & 1 & 3 \\
\hline 20 Artigos Plásticos & 183 & 15 & 7 & 35 & 13 & 19 & 75 & 143 & 335 & 320 & 223 & 183 & 318 \\
\hline 21 Indústria Têxtil & 153 & 14 & 1 & 10 & 7 & 4 & 6 & 32 & 9 & 12 & 54 & 64 & 126 \\
\hline 22 Artigos do Vestuário & 2 & 5 & 3 & 3 & 8 & 2 & 4 & 6 & 3 & 3 & 19 & 4 & 3 \\
\hline 23 Calçados & 20 & 0 & 0 & 1 & 1 & 0 & 2 & 10 & 3 & 2 & 21 & 3 & 23 \\
\hline 24 Indústria do Café & 1 & 0 & 0 & 0 & 0 & 0 & 0 & 0 & 0 & 0 & 0 & 0 & 0 \\
\hline 25 Beneficiamento de Produtos Vegetais & 36 & 1 & 0 & 1 & 2 & 1 & 1 & 1 & 1 & 1 & 1 & 1 & 4 \\
\hline 26 Abate de Animais & 42 & 0 & 0 & 1 & 3 & 0 & 0 & 0 & 0 & 0 & 0 & 0 & 7 \\
\hline 27 Indústria de Laticínios & 3 & 0 & 0 & 0 & 0 & 0 & 1 & 1 & 1 & 1 & 1 & 1 & 1 \\
\hline 28 Fabricação de Açúcar & 4 & 0 & 0 & 1 & 1 & 1 & 1 & 1 & 0 & 0 & 0 & 0 & 0 \\
\hline 29 Fabricação de Óleos Vegetais & 505 & 1 & 0 & 1 & 1 & 1 & 1 & 1 & 1 & 1 & 1 & 1 & 1 \\
\hline 30 Outros Produtos Alimentares & 2684 & 7 & 1 & 7 & 4 & 2 & 7 & 8 & 4 & 3 & 3 & 4 & 8 \\
\hline 31 Indústrias Diversas & 39 & 15 & 22 & 25 & 233 & 131 & 41 & 17 & 18 & 23 & 37 & 28 & 10 \\
\hline 32 Serviços Industriais de Utilidade Pública & 285 & 211 & 141 & 430 & 645 & 445 & 326 & 248 & 108 & 60 & 93 & 176 & 188 \\
\hline 33 Construção Civil & 3 & 23 & 46 & 30 & 26 & 16 & 38 & 50 & 21 & 25 & 26 & 33 & 20 \\
\hline 34 Comércio & 1816 & 202 & 116 & 268 & 443 & 140 & 629 & 599 & 562 & 510 & 543 & 556 & 551 \\
\hline 35 Supermercados & 0 & 0 & 0 & 0 & 0 & 0 & 0 & 0 & 0 & 0 & 0 & 0 & 0 \\
\hline 36 Transportes & 1441 & 322 & 96 & 604 & 671 & 180 & 291 & 236 & 214 & 225 & 436 & 161 & 293 \\
\hline 37 Comunicações & 17 & 31 & 25 & 76 & 82 & 39 & 87 & 153 & 81 & 105 & 75 & 67 & 59 \\
\hline 38 Instituições Financeiras & 371 & 191 & 174 & 143 & 294 & 131 & 147 & 113 & 165 & 178 & 248 & 166 & 42 \\
\hline 39 Serviços Prestados às Famílias & 205 & 72 & 56 & 91 & 97 & 27 & 66 & 128 & 57 & 63 & 83 & 49 & 74 \\
\hline 40 Serviços Prestados às Empresas & 480 & 172 & 221 & 84 & 97 & 32 & 89 & 142 & 136 & 154 & 210 & 103 & 61 \\
\hline 41 Aluguel de Imóveis & 12 & 54 & 21 & 71 & 25 & 22 & 83 & 85 & 56 & 59 & 23 & 39 & 63 \\
\hline 42 Administração Pública & 504 & 57 & 71 & 74 & 62 & 26 & 58 & 63 & 67 & 67 & 126 & 88 & 59 \\
\hline 43 Serviços Privados não-mercantis & 0 & 0 & 0 & 0 & 0 & 0 & 0 & 0 & 0 & 0 & 0 & 0 & 0 \\
\hline Produção nacional & 28876 & 3265 & 1664 & 7863 & 15457 & 5265 & 11214 & 8303 & 7650 & 5113 & 10629 & 10839 & 6537 \\
\hline Importação & 932 & 113 & 57 & 286 & 1307 & 1059 & 392 & 966 & 666 & 2921 & 2357 & 738 & 165 \\
\hline Imposto de importação & 53 & 6 & 3 & 15 & 22 & 40 & 28 & 75 & 53 & 201 & 178 & 55 & 13 \\
\hline ICM nacional & 1581 & 3 & 5 & 25 & 6 & 5 & 17 & 10 & 15 & 12 & 6 & 10 & 8 \\
\hline ICM importado & 30 & 0 & 0 & 0 & 0 & 0 & 0 & 0 & 0 & 0 & 0 & 0 & 0 \\
\hline IPI nacional & 161 & 13 & 14 & 23 & 14 & 6 & 18 & 20 & 19 & 18 & 22 & 14 & 12 \\
\hline IPI importado & 52 & 1 & 0 & 0 & 1 & 0 & 0 & 1 & 0 & 0 & 1 & 1 & 0 \\
\hline Outros impostos indiretos líquidos nacional & 96 & 45 & 39 & 37 & 67 & 29 & 33 & 24 & 36 & 39 & 55 & 37 & 9 \\
\hline Outros impostos indiretos líquidos importado & 24 & 1 & 1 & 5 & 43 & 20 & 7 & 17 & 12 & 44 & 48 & 14 & 3 \\
\hline Consumo intermediário & 31805 & 3447 & 1783 & 8254 & 16917 & 6424 & 11708 & 9416 & 8451 & 8349 & 13294 & 11707 & 6746 \\
\hline Remunerações & 7094 & 818 & 478 & 1666 & 755 & 384 & 3774 & 4237 & 1430 & 1147 & 1041 & 2721 & 1916 \\
\hline Salários & 6483 & 638 & 314 & 1398 & 538 & 317 & 3211 & 3565 & 1204 & 964 & 850 & 2281 & 1672 \\
\hline Contribuições sociais efetivas & 611 & 180 & 164 & 268 & 217 & 67 & 564 & 673 & 226 & 183 & 191 & 440 & 244 \\
\hline Previdência oficial/FGTS & 607 & 99 & 61 & 252 & 104 & 61 & 557 & 667 & 214 & 171 & 157 & 423 & 241 \\
\hline Previdência privada & 4 & 81 & 103 & 17 & 114 & 6 & 7 & 5 & 12 & 12 & 34 & 17 & 3 \\
\hline Contribuições sociais fictícias & 0 & 0 & 0 & 0 & 0 & 0 & 0 & 0 & 0 & 0 & 0 & 0 & 0 \\
\hline Excedente operacional bruto (EOB) & 46327 & 1479 & 1836 & 4409 & 4080 & 2096 & 2954 & 7262 & 2321 & 4395 & 3839 & 3186 & 2799 \\
\hline Rendimento de autônomos & 255 & 106 & 0 & 44 & 0 & 0 & 268 & 0 & 0 & 0 & 0 & 0 & 510 \\
\hline EOB Exclusive rendimento de autônomos & 46072 & 1373 & 1836 & 4365 & 4080 & 2096 & 2686 & 7262 & 2321 & 4395 & 3839 & 3186 & 2289 \\
\hline Valor adicionado a custo de fatores & 53421 & 2297 & 2315 & 6075 & 4835 & 2480 & 6729 & 11500 & 3751 & 5542 & 4880 & 5906 & 4716 \\
\hline Outros impostos sobre a produção & 2 & 196 & 138 & 488 & 689 & 286 & 672 & 774 & 417 & 460 & 590 & 622 & 398 \\
\hline Outros subsídios à produção & (-) 1930 & 0 & 0 & 0 & 0 & 0 & $(-) 0$ & $(-) 6$ & $(-) 3$ & 0 & 0 & (-) 17 & 0 \\
\hline Valor adicionado a preço básico & 51493 & 2493 & 2452 & 6564 & 5524 & 2766 & 7400 & 12267 & 4165 & 6002 & 5471 & 6511 & 5114 \\
\hline Valor da produção & 83300 & 5949 & 4233 & 14802 & 22389 & 9188 & 19119 & 21866 & 12632 & 14338 & 18762 & 18234 & 11856 \\
\hline Pessoal ocupado & 15163 & 230 & 31 & 444 & 96 & 56 & 612 & 422 & 153 & 123 & 88 & 236 & 843 \\
\hline
\end{tabular}


ANEXO C - Matriz de insumo-produto do ano de 1995, valores nominais em milhões de $\mathrm{R} \$$ (metodologia tradicional).

\begin{tabular}{|c|c|c|c|c|c|c|c|c|c|c|c|c|c|c|}
\hline Setores & 14 & 15 & 16 & 17 & 18 & 19 & 20 & 21 & 22 & 23 & 24 & 25 & 26 & 27 \\
\hline 1 Agropecuária & 475 & 276 & 2207 & 0 & 113 & 24 & 0 & 814 & 4 & 43 & 2185 & 8061 & 8765 & 3334 \\
\hline 2 Extrativa Mineral & 40 & 6 & 172 & 16 & 80 & 21 & 0 & 1 & 0 & 4 & 0 & 3 & 6 & 0 \\
\hline 3 Petróleo e gás & 0 & 0 & 0 & 4094 & 14 & 0 & 0 & 0 & 0 & 0 & 0 & 0 & 0 & 0 \\
\hline 4 Minerais não-metálicos & 39 & 4 & 105 & 50 & 65 & 189 & 18 & 2 & 1 & 4 & 12 & 125 & 4 & 6 \\
\hline 5 Siderurgia & 5 & 2 & 9 & 76 & 166 & 6 & 1 & 2 & 1 & 1 & 0 & 5 & 2 & 1 \\
\hline 6 Metalurgia de não-ferrosos & 70 & 1 & 24 & 7 & 55 & 2 & 0 & 1 & 0 & 0 & 0 & 2 & 1 & 1 \\
\hline 7 Outros Produtos Metalúrgicos & 103 & 73 & 105 & 177 & 179 & 83 & 36 & 76 & 36 & 35 & 8 & 231 & 115 & 74 \\
\hline 8 Máquinas e Equipamentos & 369 & 78 & 396 & 496 & 111 & 67 & 72 & 245 & 26 & 35 & 7 & 109 & 78 & 31 \\
\hline 9 Material Elétrico & 13 & 6 & 26 & 18 & 10 & 3 & 5 & 10 & 1 & 2 & 1 & 6 & 4 & 2 \\
\hline 10 Equipamentos Eletrônicos & 13 & 2 & 14 & 13 & 5 & 3 & 3 & 11 & 1 & 2 & 1 & 6 & 4 & 1 \\
\hline 11 Automóveis, caminhões e ônibus & 5 & 1 & 5 & 6 & 2 & 1 & 1 & 3 & 1 & 1 & 0 & 3 & 2 & 1 \\
\hline 12 Peças e outros veículos & 9 & 10 & 9 & 11 & 5 & 3 & 3 & 6 & 1 & 3 & 0 & 5 & 3 & 2 \\
\hline 13 Madeira e Mobiliário & 133 & 3 & 2 & 6 & 44 & 4 & 13 & 12 & 8 & 31 & 1 & 39 & 19 & 2 \\
\hline 14 Celulose, Papel e Gráfica & 4527 & 16 & 33 & 196 & 129 & 330 & 129 & 101 & 71 & 132 & 30 & 315 & 100 & 60 \\
\hline 15 Indústria da Borracha & 44 & 1573 & 31 & 24 & 29 & 13 & 19 & 50 & 16 & 281 & 1 & 11 & 7 & 3 \\
\hline 16 Elementos Químicos & 317 & 30 & 375 & 700 & 1315 & 394 & 30 & 58 & 1 & 31 & 1 & 12 & 7 & 2 \\
\hline 17 Refino de Petróleo & 469 & 775 & 426 & 8288 & 2070 & 404 & 2242 & 1060 & 67 & 190 & 27 & 182 & 83 & 52 \\
\hline 18 Químicos Diversos & 760 & 155 & 101 & 284 & 1906 & 332 & 217 & 292 & 12 & 157 & 2 & 30 & 15 & 9 \\
\hline 19 Farmacêuticos e Veterinários & 9 & 2 & 12 & 12 & 71 & 28 & 2 & 3 & 1 & 3 & 0 & 4 & 6 & 2 \\
\hline 20 Artigos Plásticos & 74 & 12 & 16 & 44 & 162 & 191 & 425 & 111 & 57 & 239 & 11 & 107 & 150 & 119 \\
\hline 21 Indústria Têxtil & 46 & 240 & 6 & 32 & 21 & 8 & 78 & 5679 & 3811 & 105 & 12 & 74 & 9 & 3 \\
\hline 22 Artigos do Vestuário & 5 & 5 & 3 & 9 & 2 & 3 & 2 & 13 & 24 & 5 & 1 & 3 & 3 & 1 \\
\hline 23 Calçados & 4 & 9 & 1 & 0 & 11 & 2 & 3 & 9 & 75 & 870 & 0 & 1 & 19 & 1 \\
\hline 24 Indústria do Café & 1 & 0 & 0 & 0 & 0 & 1 & 0 & 0 & 0 & 0 & 1384 & 3 & 0 & 0 \\
\hline 25 Beneficiamento de Produtos Vegetais & 42 & 1 & 3 & 2 & 27 & 27 & 1 & 8 & 1 & 1 & 4 & 576 & 38 & 40 \\
\hline 26 Abate de Animais & 3 & 1 & 5 & 0 & 3 & 28 & 0 & 2 & 0 & 434 & 0 & 30 & 1667 & 0 \\
\hline 27 Indústria de Laticínios & 1 & 0 & 0 & 1 & 3 & 8 & 0 & 1 & 0 & 1 & 0 & 14 & 6 & 1483 \\
\hline 28 Fabricação de Açúcar & 1 & 0 & 409 & 1 & 13 & 14 & 0 & 1 & 0 & 0 & 0 & 106 & 0 & 32 \\
\hline 29 Fabricação de Óleos Vegetais & 2 & 0 & 93 & 23 & 194 & 581 & 0 & 5 & 1 & 1 & 0 & 71 & 5 & 23 \\
\hline 30 Outros Produtos Alimentares & 9 & 2 & 7 & 4 & 11 & 16 & 2 & 8 & 4 & 5 & 2 & 35 & 92 & 16 \\
\hline 31 Indústrias Diversas & 235 & 17 & 40 & 47 & 48 & 15 & 19 & 26 & 21 & 14 & 6 & 13 & 12 & 11 \\
\hline 32 Serviços Industriais de Utilidade Pública & 495 & 60 & 467 & 484 & 83 & 59 & 119 & 279 & 57 & 63 & 17 & 164 & 146 & 53 \\
\hline 33 Construção Civil & 53 & 6 & 33 & 63 & 21 & 19 & 11 & 21 & 8 & 9 & 4 & 19 & 28 & 10 \\
\hline 34 Comércio & 1075 & 146 & 193 & 495 & 400 & 539 & 193 & 711 & 366 & 183 & 94 & 1055 & 600 & 128 \\
\hline 35 Supermercados & 0 & 0 & 0 & 0 & 0 & 0 & 0 & 0 & 0 & 0 & 0 & 0 & 0 & 0 \\
\hline 36 Transportes & 332 & 86 & 218 & 1318 & 368 & 275 & 83 & 211 & 69 & 103 & 60 & 356 & 454 & 128 \\
\hline 37 Comunicações & 186 & 18 & 34 & 105 & 67 & 64 & 37 & 53 & 37 & 26 & 14 & 51 & 57 & 21 \\
\hline 38 Instituições Financeiras & 205 & 25 & 152 & 408 & 203 & 5 & 34 & 155 & 24 & 21 & 19 & 105 & 130 & 33 \\
\hline 39 Serviços Prestados às Famílias & 120 & 23 & 45 & 75 & 48 & 39 & 26 & 66 & 50 & 20 & 14 & 67 & 63 & 32 \\
\hline 40 Serviços Prestados às Empresas & 243 & 31 & 49 & 163 & 70 & 280 & 47 & 72 & 79 & 46 & 26 & 143 & 113 & 52 \\
\hline 41 Aluguel de Imóveis & 154 & 13 & 14 & 56 & 44 & 49 & 41 & 55 & 69 & 23 & 8 & 40 & 44 & 14 \\
\hline 42 Administração Pública & 897 & 17 & 24 & 89 & 128 & 142 & 37 & 45 & 35 & 39 & 13 & 184 & 52 & 26 \\
\hline 43 Serviços Privados não-mercantis & 0 & 0 & 0 & 0 & 0 & 0 & 0 & 0 & 0 & 0 & 0 & 0 & 0 & 0 \\
\hline Produção nacional & 11582 & 3724 & 5864 & 17891 & 8297 & 4269 & 3951 & 10275 & 5039 & 3163 & 3962 & 12367 & 12909 & 5807 \\
\hline Importação & 1129 & 508 & 372 & 4995 & 1752 & 992 & 435 & 1470 & 359 & 275 & 8 & 722 & 94 & 121 \\
\hline Imposto de importação & 35 & 35 & 16 & 455 & 66 & 50 & 24 & 69 & 51 & 38 & 0 & 21 & 4 & 15 \\
\hline ICM nacional & 0 & 2 & 3 & 19 & 12 & 32 & 12 & 10 & 7 & 13 & 3 & 31 & 10 & 6 \\
\hline ICM importado & 0 & 0 & 0 & 0 & 0 & 0 & 0 & 0 & 0 & 0 & 0 & 0 & 0 & 0 \\
\hline IPI nacional & 22 & 4 & 7 & 33 & 15 & 35 & 12 & 16 & 10 & 11 & 4 & 27 & 16 & 8 \\
\hline IPI importado & 1 & 0 & 0 & 1 & 0 & 1 & 0 & 0 & 0 & 0 & 0 & 1 & 0 & 0 \\
\hline Outros impostos indiretos líquidos nacional & 45 & 6 & 35 & 113 & 45 & 1 & 7 & 34 & 5 & 4 & 4 & 23 & 29 & 8 \\
\hline Outros impostos indiretos líquidos importado & 18 & 11 & 9 & 116 & 45 & 19 & 8 & 25 & 5 & 4 & 0 & 25 & 1 & 2 \\
\hline Consumo intermediário & 12832 & 4290 & 6306 & 23624 & 10233 & 5398 & 4450 & 11899 & 5476 & 3509 & 3982 & 13216 & 13063 & 5966 \\
\hline Remunerações & 2729 & 504 & 762 & 1429 & 1687 & 1323 & 1064 & 1312 & 1451 & 941 & 276 & 1171 & 1013 & 343 \\
\hline Salários & 2315 & 424 & 643 & 967 & 1424 & 1102 & 890 & 1104 & 1264 & 798 & 240 & 980 & 869 & 288 \\
\hline Contribuições sociais efetivas & 414 & 79 & 118 & 462 & 263 & 221 & 174 & 208 & 187 & 142 & 36 & 190 & 145 & 55 \\
\hline Previdência oficial/FGTS & 402 & 74 & 110 & 166 & 244 & 200 & 170 & 206 & 187 & 141 & 36 & 169 & 137 & 53 \\
\hline Previdência privada & 12 & 5 & 8 & 297 & 19 & 21 & 4 & 3 & 0 & 1 & 0 & 21 & 8 & 2 \\
\hline Contribuições sociais fictícias & 0 & 0 & 0 & 0 & 0 & 0 & 0 & 0 & 0 & 0 & 0 & 0 & 0 & 0 \\
\hline Excedente operacional bruto (EOB) & 3048 & 1434 & 3628 & 13071 & 2354 & 2759 & 2038 & 3072 & 1684 & 804 & 1002 & 2480 & 1868 & 989 \\
\hline Rendimento de autônomos & 253 & 0 & 0 & 0 & 0 & 0 & 0 & 7 & 1467 & 9 & 8 & 28 & 23 & 0 \\
\hline EOB Exclusive rendimento de autônomos & 2795 & 1434 & 3628 & 13071 & 2354 & 2759 & 2038 & 3065 & 217 & 795 & 994 & 2451 & 1844 & 989 \\
\hline Valor adicionado a custo de fatores & 5777 & 1937 & 4390 & 14501 & 4041 & 4082 & 3103 & 4384 & 3135 & 1745 & 1278 & 3651 & 2881 & 1332 \\
\hline Outros impostos sobre a produção & 645 & 206 & 350 & 1209 & 485 & 329 & 264 & 539 & 300 & 186 & 168 & 552 & 518 & 235 \\
\hline Outros subsídios à produção & (-) 49 & 0 & 0 & 0 & 0 & 0 & 0 & $(-) 62$ & 0 & $(-) 51$ & $(-) \quad 39$ & 0 & 0 & 0 \\
\hline Valor adicionado a preço básico & 6372 & 2143 & 4740 & 15709 & 4526 & 4412 & 3367 & 4860 & 3435 & 1880 & 1407 & 4202 & 3398 & 1567 \\
\hline Valor da produção & 19129 & 6428 & 11041 & 39343 & 14741 & 9805 & 7805 & 16755 & 8908 & 5384 & 5389 & 17413 & 16457 & 7531 \\
\hline Pessoal ocupado & 434 & 67 & 78 & 68 & 159 & 129 & 165 & 308 & 1644 & 361 & 76 & 324 & 253 & 67 \\
\hline
\end{tabular}


ANEXO C - Matriz de insumo-produto do ano de 1995, valores nominais em milhões de $\mathrm{R} \$$ (metodologia tradicional).

\begin{tabular}{|c|c|c|c|c|c|c|c|c|c|c|}
\hline Setores & 28 & 29 & 30 & 31 & 32 & 33 & 34 & 35 & 36 & 37 \\
\hline 1 Agropecuária & 1629 & 4239 & 2865 & 22 & 8 & 6 & 0 & 0 & 0 & 0 \\
\hline 2 Extrativa Mineral & 0 & 3 & 105 & 212 & 3 & 298 & 3 & 1 & 1 & 0 \\
\hline 3 Petróleo e gás & 0 & 0 & 0 & 1 & 11 & 1 & 1 & 0 & 0 & 0 \\
\hline 4 Minerais não-metálicos & 19 & 6 & 358 & 111 & 3 & 7025 & 4 & 1 & 1 & 6 \\
\hline 5 Siderurgia & 1 & 5 & 8 & 40 & 1 & 586 & 5 & 1 & 5 & 1 \\
\hline 6 Metalurgia de não-ferrosos & 1 & 2 & 3 & 155 & 0 & 377 & 2 & 0 & 2 & 3 \\
\hline 7 Outros Produtos Metalúrgicos & 54 & 263 & 353 & 133 & 26 & 3736 & 63 & 19 & 115 & 41 \\
\hline 8 Máquinas e Equipamentos & 264 & 64 & 186 & 76 & 552 & 824 & 203 & 59 & 141 & 58 \\
\hline 9 Material Elétrico & 9 & 3 & 9 & 42 & 332 & 2165 & 29 & 8 & 15 & 86 \\
\hline 10 Equipamentos Eletrônicos & 8 & 3 & 8 & 10 & 8 & 36 & 7 & 1 & 9 & 109 \\
\hline 11 Automóveis, caminhões e ônibus & 2 & 3 & 6 & 1 & 44 & 30 & 7 & 2 & 29 & 1 \\
\hline 12 Peças e outros veículos & 6 & 4 & 8 & 4 & 12 & 100 & 7 & 2 & 1870 & 20 \\
\hline 13 Madeira e Mobiliário & 4 & 5 & 51 & 77 & 2 & 1878 & 80 & 13 & 32 & 1 \\
\hline 14 Celulose, Papel e Gráfica & 56 & 88 & 622 & 155 & 53 & 64 & 1124 & 198 & 138 & 45 \\
\hline 15 Indústria da Borracha & 17 & 5 & 16 & 32 & 10 & 141 & 1 & 0 & 756 & 3 \\
\hline 16 Elementos Químicos & 38 & 25 & 133 & 35 & 9 & 52 & 1826 & 0 & 43 & 28 \\
\hline 17 Refino de Petróleo & 72 & 120 & 338 & 269 & 253 & 850 & 6947 & 1 & 3867 & 4 \\
\hline 18 Químicos Diversos & 30 & 52 & 273 & 110 & 20 & 656 & 8 & 0 & 37 & 0 \\
\hline 19 Farmacêuticos e Veterinários & 1 & 3 & 94 & 2 & 5 & 4 & 6 & 1 & 2 & 0 \\
\hline 20 Artigos Plásticos & 15 & 40 & 239 & 143 & 5 & 1133 & 337 & 59 & 454 & 29 \\
\hline 21 Indústria Têxtil & 186 & 187 & 32 & 111 & 6 & 22 & 71 & 12 & 208 & 1 \\
\hline 22 Artigos do Vestuário & 5 & 1 & 5 & 2 & 0 & 11 & 4 & 1 & 5 & 4 \\
\hline 23 Calçados & 0 & 2 & 8 & 16 & 0 & 7 & 3 & 0 & 7 & 5 \\
\hline 24 Indústria do Café & 0 & 1 & 8 & 0 & 0 & 1 & 2 & 0 & 1 & 0 \\
\hline 25 Beneficiamento de Produtos Vegetais & 0 & 210 & 3008 & 1 & 0 & 5 & 6 & 1 & 4 & 0 \\
\hline 26 Abate de Animais & 0 & 92 & 192 & 6 & 0 & 2 & 4 & 1 & 2 & 0 \\
\hline 27 Indústria de Laticínios & 0 & 1 & 141 & 0 & 0 & 4 & 4 & 0 & 2 & 0 \\
\hline 28 Fabricação de Açúcar & 879 & 0 & 659 & 0 & 8 & 1 & 12 & 1 & 1 & 0 \\
\hline 29 Fabricação de Óleos Vegetais & 0 & 1972 & 1370 & 0 & 0 & 3 & 4 & 0 & 2 & 0 \\
\hline 30 Outros Produtos Alimentares & 2 & 10 & 1223 & 8 & 1 & 4 & 32 & 1 & 182 & 1 \\
\hline 31 Indústrias Diversas & 8 & 10 & 29 & 348 & 84 & 257 & 29 & 5 & 37 & 9 \\
\hline 32 Serviços Industriais de Utilidade Pública & 108 & 94 & 355 & 50 & 6925 & 99 & 743 & 216 & 147 & 60 \\
\hline 33 Construção Civil & 28 & 10 & 33 & 10 & 95 & 3488 & 104 & 104 & 219 & 50 \\
\hline 34 Comércio & 149 & 473 & 1341 & 306 & 141 & 3320 & 1643 & 91 & 1492 & 74 \\
\hline 35 Supermercados & 0 & 0 & 0 & 0 & 0 & 0 & 0 & 0 & 0 & 0 \\
\hline 36 Transportes & 144 & 395 & 578 & 105 & 91 & 964 & 2880 & 110 & 2249 & 151 \\
\hline 37 Comunicações & 16 & 30 & 100 & 61 & 55 & 118 & 629 & 189 & 284 & 12 \\
\hline 38 Instituições Financeiras & 34 & 128 & 178 & 74 & 366 & 282 & 1273 & 204 & 764 & 110 \\
\hline 39 Serviços Prestados às Famílias & 44 & 32 & 100 & 28 & 206 & 299 & 1241 & 73 & 511 & 128 \\
\hline 40 Serviços Prestados às Empresas & 53 & 54 & 287 & 392 & 413 & 759 & 2691 & 388 & 656 & 304 \\
\hline 41 Aluguel de Imóveis & 9 & 19 & 167 & 41 & 193 & 129 & 2757 & 412 & 292 & 138 \\
\hline 42 Administração Pública & 26 & 39 & 220 & 151 & 127 & 233 & 947 & 143 & 234 & 92 \\
\hline 43 Serviços Privados não-mercantis & 0 & 0 & 0 & 0 & 0 & 0 & 0 & 0 & 0 & 0 \\
\hline Produção nacional & 3917 & 8695 & 15711 & 3341 & 10072 & 29971 & 25739 & 2317 & 14811 & 1575 \\
\hline Importação & 82 & 365 & 1000 & 204 & 1055 & 1111 & 736 & 59 & 3410 & 192 \\
\hline Imposto de importação & 5 & 5 & 48 & 13 & 8 & 96 & 28 & 1 & 126 & 8 \\
\hline ICM nacional & 5 & 9 & 61 & 15 & 1200 & 5137 & 1250 & 124 & 1318 & 79 \\
\hline ICM importado & 0 & 0 & 0 & 0 & 9 & 153 & 25 & 2 & 193 & 18 \\
\hline IPI nacional & 7 & 10 & 50 & 26 & 64 & 1925 & 267 & 38 & 401 & 37 \\
\hline IPI importado & 0 & 0 & 1 & 1 & 17 & 235 & 21 & 4 & 89 & 13 \\
\hline Outros impostos indiretos líquidos nacional & 8 & 29 & 40 & 16 & 49 & 67 & 376 & 39 & 103 & 23 \\
\hline Outros impostos indiretos líquidos importado & 1 & 6 & 19 & 3 & 2 & 19 & 7 & 0 & 26 & 2 \\
\hline Consumo intermediário & 4027 & 9119 & 16931 & 3619 & 12476 & 38714 & 28450 & 2585 & 20475 & 1946 \\
\hline Remunerações & 473 & 256 & 2433 & 1077 & 7784 & 6819 & 18010 & 1436 & 9098 & 2903 \\
\hline Salários & 400 & 216 & 2056 & 916 & 6131 & 5904 & 15480 & 1235 & 7641 & 2369 \\
\hline Contribuições sociais efetivas & 73 & 40 & 377 & 161 & 1653 & 915 & 2530 & 202 & 1457 & 534 \\
\hline Previdência oficial/FGTS & 73 & 40 & 354 & 158 & 1120 & 903 & 2516 & 201 & 1271 & 335 \\
\hline Previdência privada & 0 & 0 & 23 & 4 & 533 & 12 & 14 & 1 & 186 & 199 \\
\hline Contribuições sociais fictícias & 0 & 0 & 0 & 0 & 0 & 0 & 0 & 0 & 0 & 0 \\
\hline Excedente operacional bruto (EOB) & 419 & 1110 & 3702 & 1965 & 6571 & 43009 & 27154 & 1944 & 9955 & 5451 \\
\hline Rendimento de autônomos & 0 & 0 & 58 & 91 & 0 & 3529 & 11645 & 929 & 3683 & 0 \\
\hline EOB Exclusive rendimento de autônomos & 419 & 1110 & 3644 & 1874 & 6571 & 39480 & 15509 & 1015 & 6272 & 5451 \\
\hline Valor adicionado a custo de fatores & 892 & 1367 & 6135 & 3043 & 14355 & 49828 & 45163 & 3380 & 19053 & 8354 \\
\hline Outros impostos sobre a produção & 166 & 331 & 777 & 227 & 1031 & 2898 & 2701 & 242 & 1427 & 378 \\
\hline Outros subsídios à produção & 0 & 0 & 0 & 0 & (-) 91 & $(-) 18$ & (-) 409 & 0 & (-) 851 & (-) 47 \\
\hline Valor adicionado a preço básico & 1057 & 1698 & 6912 & 3269 & 15295 & 52708 & 47456 & 3622 & 19628 & 8685 \\
\hline Valor da produção & 5092 & 10814 & 23830 & 6632 & 27772 & 91348 & 75914 & 6208 & 40072 & 10631 \\
\hline Pessoal ocupado & 95 & 50 & 670 & 272 & 255 & 3429 & 8216 & 655 & 2265 & 183 \\
\hline
\end{tabular}


ANEXO C - Matriz de insumo-produto do ano de 1995, valores nominais em milhões de $\mathrm{R} \$$ (metodologia tradicional).

\begin{tabular}{|c|c|c|c|c|c|c|c|c|}
\hline Setores & 38 & 39 & 40 & 41 & 42 & 43 & 44 & $\begin{array}{c}\text { Total } \\
\text { da atividade }\end{array}$ \\
\hline 1 Agropecuária & 0 & 1587 & 0 & 0 & 1595 & 43 & 0 & 53142 \\
\hline 2 Extrativa Mineral & 7 & 2 & 7 & 0 & 14 & 1 & 0 & 3400 \\
\hline 3 Petróleo e gás & 0 & 0 & 0 & 0 & 0 & 0 & 0 & 4272 \\
\hline 4 Minerais não-metálicos & 1 & 223 & 0 & 0 & 195 & 7 & 0 & 13285 \\
\hline 5 Siderurgia & 1 & 33 & 1 & 0 & 5 & 0 & 0 & 18459 \\
\hline 6 Metalurgia de não-ferrosos & 0 & 39 & 0 & 0 & 3 & 0 & 0 & 6738 \\
\hline 7 Outros Produtos Metalúrgicos & 13 & 207 & 25 & 3 & 48 & 6 & 0 & 16311 \\
\hline 8 Máquinas e Equipamentos & 35 & 160 & 123 & 64 & 294 & 4 & 0 & 10768 \\
\hline 9 Material Elétrico & 1 & 161 & 24 & 17 & 149 & 2 & 0 & 5931 \\
\hline 10 Equipamentos Eletrônicos & 1 & 122 & 34 & 1 & 66 & 0 & 0 & 1838 \\
\hline 11 Automóveis, caminhões e ônibus & 3 & 123 & 2 & 1 & 73 & 0 & 0 & 846 \\
\hline 12 Peças e outros veículos & 1 & 1934 & 3 & 1 & 492 & 0 & 0 & 12531 \\
\hline 13 Madeira e Mobiliário & 10 & 142 & 11 & 1 & 101 & 1 & 0 & 5106 \\
\hline 14 Celulose, Papel e Gráfica & 312 & 267 & 2006 & 12 & 2141 & 17 & 0 & 14760 \\
\hline 15 Indústria da Borracha & 0 & 994 & 0 & 0 & 49 & 0 & 0 & 5712 \\
\hline 16 Elementos Químicos & 0 & 199 & 0 & 0 & 352 & 0 & 0 & 6990 \\
\hline 17 Refino de Petróleo & 29 & 150 & 112 & 2 & 434 & 14 & 0 & 34778 \\
\hline 18 Químicos Diversos & 1 & 250 & 1 & 0 & 337 & 0 & 0 & 13075 \\
\hline 19 Farmacêuticos e Veterinários & 2 & 444 & 1 & 0 & 28 & 0 & 0 & 1013 \\
\hline 20 Artigos Plásticos & 4 & 248 & 11 & 35 & 232 & 11 & 0 & 6581 \\
\hline 21 Indústria Têxtil & 12 & 731 & 12 & 1 & 238 & 1 & 0 & 12444 \\
\hline 22 Artigos do Vestuário & 0 & 10 & 1 & 0 & 44 & 0 & 0 & 237 \\
\hline 23 Calçados & 0 & 44 & 0 & 0 & 9 & 0 & 0 & 1194 \\
\hline 24 Indústria do Café & 0 & 374 & 0 & 0 & 40 & 13 & 0 & 1834 \\
\hline 25 Beneficiamento de Produtos Vegetais & 1 & 419 & 1 & 0 & 234 & 9 & 0 & 4719 \\
\hline 26 Abate de Animais & 1 & 938 & 0 & 0 & 348 & 48 & 0 & 3866 \\
\hline 27 Indústria de Laticínios & 1 & 271 & 0 & 0 & 393 & 10 & 0 & 2356 \\
\hline 28 Fabricação de Açúcar & 1 & 345 & 0 & 0 & 20 & 11 & 0 & 2527 \\
\hline 29 Fabricação de Óleos Vegetais & 1 & 229 & 0 & 0 & 5 & 6 & 0 & 5105 \\
\hline 30 Outros Produtos Alimentares & 2 & 3430 & 1 & 0 & 162 & 37 & 0 & 8050 \\
\hline 31 Indústrias Diversas & 415 & 80 & 435 & 20 & 801 & 37 & 0 & 3766 \\
\hline 32 Serviços Industriais de Utilidade Pública & 304 & 891 & 187 & 120 & 2657 & 40 & 0 & 18895 \\
\hline 33 Construção Civil & 0 & 270 & 80 & 2861 & 942 & 14 & 0 & 8969 \\
\hline 34 Comércio & 462 & 4730 & 372 & 18 & 4114 & 34 & 0 & 31869 \\
\hline 35 Supermercados & 0 & 149 & 0 & 0 & 0 & 0 & 0 & 149 \\
\hline 36 Transportes & 666 & 591 & 309 & 5 & 1555 & 19 & 0 & 20044 \\
\hline 37 Comunicações & 906 & 280 & 337 & 21 & 1139 & 11 & 0 & 5855 \\
\hline 38 Instituições Financeiras & 4315 & 337 & 229 & 123 & 846 & 1 & 36245 & 49393 \\
\hline 39 Serviços Prestados às Famílias & 1888 & 587 & 266 & 10 & 7692 & 27 & 0 & 14889 \\
\hline 40 Serviços Prestados às Empresas & 3722 & 688 & 1126 & 38 & 9515 & 23 & 0 & 24504 \\
\hline 41 Aluguel de Imóveis & 791 & 263 & 290 & 36 & 902 & 79 & 0 & 7756 \\
\hline 42 Administração Pública & 1088 & 316 & 685 & 13 & 3047 & 12 & 0 & 10422 \\
\hline 43 Serviços Privados não-mercantis & 0 & 0 & 0 & 0 & 0 & 0 & 0 & 0 \\
\hline Produção nacional & 15000 & 23257 & 6695 & 3406 & 41315 & 537 & 36245 & 474379 \\
\hline Importação & 444 & 828 & 273 & 20 & 2411 & 17 & 234 & 37634 \\
\hline Imposto de importação & 9 & 64 & 13 & 1 & 79 & 1 & 0 & 2124 \\
\hline ICM nacional & 457 & 3282 & 484 & 43 & 1958 & 54 & 0 & 17339 \\
\hline ICM importado & 17 & 103 & 21 & 2 & 161 & 2 & 0 & 735 \\
\hline IPI nacional & 242 & 1078 & 193 & 20 & 842 & 10 & 91 & 5875 \\
\hline IPI importado & 23 & 100 & 26 & 3 & 179 & 2 & 1 & 779 \\
\hline Outros impostos indiretos líquidos nacional & 207 & 72 & 48 & 27 & 2 & 0 & 0 & 2009 \\
\hline Outros impostos indiretos líquidos importado & 2 & 14 & 3 & 0 & 24 & 0 & 0 & 658 \\
\hline Consumo intermediário & 16400 & 28799 & 7757 & 3523 & 46971 & 624 & 36570 & 541534 \\
\hline Remunerações & 24936 & 18335 & 9858 & 1122 & 92183 & 7086 & 0 & 247277 \\
\hline Salários & 20405 & 15794 & 8386 & 1016 & 60149 & 6568 & 0 & 191410 \\
\hline Contribuições sociais efetivas & 4531 & 2541 & 1472 & 106 & 6342 & 518 & 0 & 30176 \\
\hline Previdência oficial/FGTS & 3318 & 2529 & 1466 & 106 & 6280 & 501 & 0 & 27077 \\
\hline Previdência privada & 1213 & 12 & 6 & 0 & 62 & 17 & 0 & 3099 \\
\hline Contribuições sociais fictícias & 0 & 0 & 0 & 0 & 25692 & 0 & 0 & 25692 \\
\hline Excedente operacional bruto (EOB) & 18465 & 21518 & 8448 & 57986 & 0 & 33 & (-) 36570 & 298374 \\
\hline Rendimento de autônomos & 1753 & 10340 & 2776 & 346 & 0 & 0 & 0 & 38129 \\
\hline EOB Exclusive rendimento de autônomos & 16712 & 11178 & 5672 & 57640 & 0 & 33 & (-) 36570 & 260245 \\
\hline Valor adicionado a custo de fatores & 43401 & 39853 & 18306 & 59108 & 92183 & 7120 & (-) 36570 & 545651 \\
\hline Outros impostos sobre a produção & 2455 & 2595 & 1089 & 451 & 1185 & 71 & 0 & 29742 \\
\hline Outros subsídios à produção & 0 & 0 & 0 & 0 & 0 & 0 & 0 & (-) 3575 \\
\hline Valor adicionado a preço básico & 45856 & 42448 & 19396 & 59559 & 93368 & 7190 & (-) 36570 & 571818 \\
\hline Valor da produção & 62256 & 71208 & 27516 & 63093 & 140339 & 7829 & 0 & 1113352 \\
\hline Pessoal ocupado & 799 & 8663 & 2032 & 287 & 5320 & 5407 & 0 & 61226 \\
\hline
\end{tabular}


ANEXO C - Matriz de insumo-produto do ano de 1995, valores nominais em milhões de $\mathrm{R} \$$ (metodologia tradicional).

\begin{tabular}{|c|c|c|c|c|c|c|c|}
\hline Setores & $\begin{array}{l}\text { Formação bruta } \\
\text { de capital fixo }\end{array}$ & $\begin{array}{c}\text { Exportação } \\
\text { de bens e serviços }\end{array}$ & $\begin{array}{c}\text { Variação } \\
\text { de estoque }\end{array}$ & $\begin{array}{l}\text { Consumo do } \\
\text { Governo }\end{array}$ & $\begin{array}{c}\text { Consumo } \\
\text { das famílias }\end{array}$ & $\begin{array}{c}\text { Demanda } \\
\text { final }\end{array}$ & $\begin{array}{c}\text { Demanda } \\
\text { total }\end{array}$ \\
\hline 1 Agropecuária & 2964 & 1363 & 3193 & 0 & 22638 & 30158 & 83300 \\
\hline 2 Extrativa Mineral & 1 & 2244 & 254 & 0 & 49 & 2548 & 5949 \\
\hline 3 Petróleo e gás & 0 & 53 & $(-) 96$ & 0 & 4 & $(-) 39$ & 4233 \\
\hline 4 Minerais não-metálicos & 6 & 623 & 192 & 0 & 696 & 1517 & 14802 \\
\hline 5 Siderurgia & 6 & 3653 & 218 & 0 & 54 & 3930 & 22389 \\
\hline 6 Metalurgia de não-ferrosos & 4 & 2027 & 208 & 0 & 212 & 2450 & 9188 \\
\hline 7 Outros Produtos Metalúrgicos & 560 & 874 & 117 & 0 & 1257 & 2809 & 19119 \\
\hline 8 Máquinas e Equipamentos & 8880 & 1985 & $(-) 540$ & 0 & 774 & 11098 & 21866 \\
\hline 9 Material Elétrico & 1545 & 1325 & 302 & 0 & 3531 & 6701 & 12632 \\
\hline 10 Equipamentos Eletrônicos & 4815 & 703 & 207 & 0 & 6775 & 12500 & 14338 \\
\hline 11 Automóveis, caminhões e ônibus & 7134 & 1248 & 326 & 0 & 9208 & 17915 & 18762 \\
\hline 12 Peças e outros veículos & 1380 & 2861 & 224 & 0 & 1237 & 5703 & 18234 \\
\hline 13 Madeira e Mobiliário & 1328 & 1136 & 87 & 0 & 4199 & 6750 & 11856 \\
\hline 14 Celulose, Papel e Gráfica & 49 & 2054 & 32 & 0 & 2234 & 4369 & 19129 \\
\hline 15 Indústria da Borracha & 1 & 532 & 88 & 0 & 95 & 716 & 6428 \\
\hline 16 Elementos Químicos & 2 & 638 & (-) 4 & 0 & 3415 & 4051 & 11041 \\
\hline 17 Refino de Petróleo & (-) 57 & 1787 & 1660 & 0 & 1176 & 4565 & 39343 \\
\hline 18 Químicos Diversos & 9 & 645 & 207 & 0 & 805 & 1666 & 14741 \\
\hline 19 Farmacêuticos e Veterinários & 2 & 290 & 96 & 0 & 8403 & 8792 & 9805 \\
\hline 20 Artigos Plásticos & 8 & 224 & 395 & 0 & 596 & 1224 & 7805 \\
\hline 21 Indústria Têxtil & 5 & 1061 & 296 & 0 & 2949 & 4310 & 16755 \\
\hline 22 Artigos do Vestuário & 0 & 151 & 2 & 0 & 8518 & 8671 & 8908 \\
\hline 23 Calçados & 0 & 1845 & 98 & 0 & 2248 & 4190 & 5384 \\
\hline 24 Indústria do Café & 1 & 1618 & (-) 4 & 0 & 1940 & 3555 & 5389 \\
\hline 25 Beneficiamento de Produtos Vegetais & 9 & 1861 & 128 & 0 & 10696 & 12694 & 17413 \\
\hline 26 Abate de Animais & 13 & 1058 & 464 & 0 & 11055 & 12591 & 16457 \\
\hline 27 Indústria de Laticínios & 4 & 12 & 90 & 0 & 5070 & 5175 & 7531 \\
\hline 28 Fabricação de Açúcar & 1 & 1614 & $(-) \quad 107$ & 0 & 1057 & 2565 & 5092 \\
\hline 29 Fabricação de Óleos Vegetais & 3 & 2655 & 106 & 0 & 2946 & 5710 & 10814 \\
\hline 30 Outros Produtos Alimentares & 7 & 943 & 214 & 0 & 14617 & 15781 & 23830 \\
\hline 31 Indústrias Diversas & 95 & 458 & 66 & 0 & 2246 & 2865 & 6632 \\
\hline 32 Serviços Industriais de Utilidade Pública & 13 & 10 & 0 & 0 & 8854 & 8877 & 27772 \\
\hline 33 Construção Civil & 82370 & 0 & 0 & 0 & 8 & 82379 & 91348 \\
\hline 34 Comércio & 3391 & 1442 & 548 & 0 & 38663 & 44045 & 75914 \\
\hline 35 Supermercados & 0 & 0 & 0 & 0 & 6059 & 6059 & 6208 \\
\hline 36 Transportes & 378 & 4582 & 200 & 0 & 14868 & 20028 & 40072 \\
\hline 37 Comunicações & 7 & 64 & 4 & 0 & 4702 & 4776 & 10631 \\
\hline 38 Instituições Financeiras & 0 & 234 & 0 & 0 & 12629 & 12863 & 62256 \\
\hline 39 Serviços Prestados às Famílias & 10 & 994 & 3 & 0 & 55312 & 56319 & 71208 \\
\hline 40 Serviços Prestados às Empresas & 1255 & 923 & 1 & 0 & 833 & 3012 & 27516 \\
\hline 41 Aluguel de Imóveis & 0 & 2 & 0 & 0 & 55335 & 55337 & 63093 \\
\hline 42 Administração Pública & 418 & 715 & 20 & 126652 & 2112 & 129917 & 140339 \\
\hline 43 Serviços Privados não-mercantis & 0 & 0 & 0 & 0 & 7829 & 7829 & 7829 \\
\hline Produção nacional & 116617 & 48505 & 9296 & 126652 & 337902 & 638973 & 1113352 \\
\hline Importação & 9073 & 189 & 756 & 0 & 13663 & 23680 & 61314 \\
\hline Imposto de importação & 849 & 23 & 36 & 0 & 1844 & 2751 & 4876 \\
\hline ICM nacional & 2945 & 672 & 770 & 0 & 23693 & 28079 & 45419 \\
\hline ICM importado & 689 & 0 & 46 & 0 & 1183 & 1918 & 2653 \\
\hline IPI nacional & 1102 & 383 & 302 & 0 & 5909 & 7696 & 13571 \\
\hline IPI importado & 1320 & 0 & 53 & 0 & 925 & 2298 & 3076 \\
\hline Outros impostos indiretos líquidos nacional & 0 & 140 & $(-) 1$ & 0 & 1618 & 1757 & 3767 \\
\hline Outros impostos indiretos líquidos importado & 158 & 4 & 16 & 0 & 174 & 353 & 1011 \\
\hline Consumo intermediário & 132753 & 49917 & 11274 & 126652 & 386910 & 707506 & 1249039 \\
\hline Remunerações & 0 & 0 & 0 & 0 & 0 & 0 & 247277 \\
\hline Salários & 0 & 0 & 0 & 0 & 0 & 0 & 191410 \\
\hline Contribuições sociais efetivas & 0 & 0 & 0 & 0 & 0 & 0 & 30176 \\
\hline Previdência oficial/FGTS & 0 & 0 & 0 & 0 & 0 & 0 & 27077 \\
\hline Previdência privada & 0 & 0 & 0 & 0 & 0 & 0 & 3099 \\
\hline Contribuições sociais fictícias & 0 & 0 & 0 & 0 & 0 & 0 & 25692 \\
\hline Excedente operacional bruto (EOB) & 0 & 0 & 0 & 0 & 0 & 0 & 298374 \\
\hline Rendimento de autônomos & 0 & 0 & 0 & 0 & 0 & 0 & 38129 \\
\hline EOB Exclusive rendimento de autônomos & 0 & 0 & 0 & 0 & 0 & 0 & 260245 \\
\hline Valor adicionado a custo de fatores & 0 & 0 & 0 & 0 & 0 & 0 & 545651 \\
\hline Outros impostos sobre a produção & 0 & 0 & 0 & 0 & 0 & 0 & 29742 \\
\hline Outros subsídios à produção & 0 & 0 & 0 & 0 & 0 & 0 & (-) 3575 \\
\hline Valor adicionado a preço básico & 0 & 0 & 0 & 0 & 0 & 0 & 571818 \\
\hline Valor da produção & 0 & 0 & 0 & 0 & 0 & 0 & 1113352 \\
\hline Pessoal ocupado & 0 & 0 & 0 & 0 & 0 & 0 & 0 \\
\hline
\end{tabular}


ANEXO D - Matriz de insumo-produto do Brasil do ano de 1999, valores nominais em milhões de $\mathrm{R} \$$ (metodologia tradicional).

\begin{tabular}{|c|c|c|c|c|c|c|c|c|c|c|c|c|c|}
\hline Setores & 1 & 2 & 3 & 4 & 5 & 6 & 7 & 8 & 9 & 10 & 11 & 12 & 13 \\
\hline 1 Agropecuária & 18346 & 12 & 0 & 135 & 971 & 21 & 7 & 0 & 0 & 1 & 0 & 0 & 2147 \\
\hline 2 Extrativa Mineral & 300 & 668 & 9 & 668 & 854 & 672 & 69 & 0 & 27 & 20 & 1 & 1 & 0 \\
\hline 3 Petróleo e gás & 1 & 0 & 3 & 5 & 150 & 2 & 3 & 0 & 0 & 0 & 0 & 0 & 0 \\
\hline 4 Minerais não-metálicos & 96 & 97 & 75 & 3398 & 217 & 217 & 196 & 154 & 300 & 145 & 148 & 117 & 70 \\
\hline 5 Siderurgia & 7 & 5 & 46 & 293 & 12316 & 93 & 6702 & 1565 & 595 & 98 & 846 & 1162 & 70 \\
\hline 6 Metalurgia de não-ferrosos & 5 & 2 & 28 & 3 & 241 & 3755 & 1139 & 490 & 1588 & 177 & 122 & 815 & 56 \\
\hline 7 Outros Produtos Metalúrgicos & 199 & 249 & 319 & 192 & 565 & 244 & 2051 & 2222 & 878 & 310 & 610 & 2586 & 285 \\
\hline 8 Máquinas e Equipamentos & 252 & 347 & 291 & 294 & 641 & 247 & 534 & 772 & 714 & 149 & 420 & 839 & 89 \\
\hline 9 Material Elétrico & 13 & 13 & 9 & 13 & 55 & 21 & 54 & 424 & 1183 & 299 & 50 & 125 & 7 \\
\hline 10 Equipamentos Eletrônicos & 8 & 10 & 5 & 14 & 22 & 6 & 13 & 64 & 58 & 861 & 12 & 31 & 4 \\
\hline 11 Automóveis, caminhões e ônibus & 7 & 5 & 6 & 8 & 13 & 8 & 18 & 28 & 10 & 3 & 198 & 96 & 5 \\
\hline 12 Peças e outros veículos & 16 & 11 & 8 & 8 & 18 & 24 & 37 & 260 & 43 & 12 & 3633 & 2279 & 15 \\
\hline 13 Madeira e Mobiliário & 138 & 10 & 9 & 22 & 29 & 27 & 63 & 66 & 61 & 168 & 83 & 117 & 1784 \\
\hline 14 Celulose, Papel e Gráfica & 62 & 45 & 108 & 377 & 90 & 76 & 243 & 152 & 220 & 118 & 69 & 142 & 116 \\
\hline 15 Indústria da Borracha & 6 & 35 & 10 & 46 & 88 & 14 & 57 & 203 & 52 & 14 & 713 & 182 & 44 \\
\hline 16 Elementos Químicos & 229 & 20 & 2 & 234 & 166 & 499 & 89 & 36 & 57 & 12 & 24 & 31 & 27 \\
\hline 17 Refino de Petróleo & 3310 & 495 & 137 & 1174 & 468 & 148 & 396 & 277 & 490 & 82 & 135 & 362 & 422 \\
\hline 18 Químicos Diversos & 9398 & 220 & 81 & 332 & 182 & 338 & 267 & 161 & 192 & 33 & 287 & 143 & 389 \\
\hline 19 Farmacêuticos e Veterinários & 462 & 6 & 2 & 5 & 5 & 11 & 3 & 2 & 2 & 1 & 2 & 2 & 4 \\
\hline 20 Artigos Plásticos & 292 & 18 & 12 & 46 & 15 & 27 & 93 & 179 & 405 & 256 & 227 & 219 & 398 \\
\hline 21 Indústria Têxtil & 224 & 14 & 2 & 13 & 7 & 4 & 7 & 36 & 10 & 8 & 52 & 69 & 160 \\
\hline 22 Artigos do Vestuário & 3 & 4 & 3 & 2 & 6 & 1 & 3 & 4 & 2 & 2 & 11 & 3 & 3 \\
\hline 23 Calçados & 27 & 0 & 0 & 1 & 1 & 0 & 3 & 9 & 3 & 2 & 17 & 3 & 22 \\
\hline 24 Indústria do Café & 1 & 0 & 0 & 0 & 0 & 0 & 0 & 0 & 0 & 0 & 0 & 0 & 0 \\
\hline 25 Beneficiamento de Produtos Vegetais & 67 & 1 & 1 & 2 & 3 & 2 & 2 & 2 & 2 & 1 & 2 & 2 & 6 \\
\hline 26 Abate de Animais & 77 & 0 & 0 & 1 & 5 & 0 & 1 & 1 & 1 & 0 & 1 & 1 & 12 \\
\hline 27 Indústria de Laticínios & 6 & 0 & 0 & 1 & 1 & 1 & 1 & 1 & 1 & 1 & 2 & 2 & 1 \\
\hline 28 Fabricação de Açúcar & 7 & 1 & 1 & 1 & 2 & 1 & 1 & 1 & 1 & 0 & 1 & 1 & 1 \\
\hline 29 Fabricação de Óleos Vegetais & 930 & 1 & 0 & 1 & 1 & 2 & 1 & 1 & 1 & 1 & 1 & 1 & 1 \\
\hline 30 Outros Produtos Alimentares & 4252 & 8 & 2 & 10 & 6 & 3 & 9 & 11 & 5 & 3 & 4 & 6 & 12 \\
\hline 31 Indústrias Diversas & 68 & 14 & 29 & 24 & 202 & 133 & 38 & 17 & 17 & 14 & 28 & 26 & 10 \\
\hline 32 Serviços Industriais de Utilidade Pública & 654 & 369 & 384 & 830 & 1134 & 913 & 604 & 459 & 192 & 70 & 138 & 310 & 349 \\
\hline 33 Construção Civil & 5 & 30 & 94 & 43 & 34 & 24 & 53 & 69 & 28 & 22 & 29 & 44 & 27 \\
\hline 34 Comércio & 4691 & 340 & 278 & 844 & 769 & 583 & 923 & 1111 & 900 & 610 & 1478 & 1335 & 1044 \\
\hline 35 Supermercados & 0 & 0 & 0 & 0 & 0 & 0 & 0 & 0 & 0 & 0 & 0 & 0 & 0 \\
\hline 36 Transportes & 2208 & 358 & 188 & 772 & 784 & 263 & 385 & 300 & 263 & 174 & 463 & 193 & 352 \\
\hline 37 Comunicações & 65 & 94 & 114 & 253 & 219 & 119 & 276 & 498 & 254 & 217 & 194 & 204 & 193 \\
\hline 38 Instituições Financeiras & 675 & 299 & 428 & 246 & 463 & 240 & 243 & 187 & 264 & 188 & 334 & 263 & 69 \\
\hline 39 Serviços Prestados às Famílias & 110 & 33 & 40 & 50 & 46 & 18 & 38 & 81 & 36 & 27 & 38 & 32 & 40 \\
\hline 40 Serviços Prestados às Empresas & 1121 & 346 & 693 & 186 & 195 & 76 & 187 & 302 & 279 & 209 & 362 & 210 & 130 \\
\hline 41 Aluguel de Imóveis & 16 & 59 & 36 & 85 & 27 & 28 & 95 & 98 & 62 & 44 & 22 & 43 & 73 \\
\hline 42 Administração Pública & 566 & 63 & 124 & 80 & 60 & 29 & 62 & 70 & 72 & 49 & 107 & 77 & 60 \\
\hline 43 Serviços Privados não-mercantis & 0 & 0 & 0 & 0 & 0 & 0 & 0 & 0 & 0 & 0 & 0 & 0 & 0 \\
\hline Produção nacional & 48918 & 4303 & 3579 & 10710 & 21073 & 8892 & 14966 & 10314 & 9265 & 4402 & 10865 & 12074 & 8497 \\
\hline Importação & 4097 & 493 & 464 & 1001 & 2053 & 1482 & 1247 & 1284 & 1604 & 1537 & 3007 & 2505 & 448 \\
\hline Imposto de importação & 174 & 30 & 23 & 59 & 77 & 95 & 102 & 114 & 155 & 145 & 198 & 186 & 40 \\
\hline ICM nacional e importado & 1654 & 177 & 159 & 874 & 507 & 350 & 556 & 623 & 527 & 367 & 882 & 817 & 461 \\
\hline IPI nacional e importado & 226 & 70 & 84 & 208 & 159 & 130 & 315 & 296 & 306 & 172 & 338 & 362 & 125 \\
\hline Oiil nacional e importado & 197 & 72 & 100 & 64 & 138 & 65 & 63 & 48 & 69 & 50 & 94 & 72 & 17 \\
\hline Consumo intermediário & 55265 & 5144 & 4409 & 12916 & 24007 & 11012 & 17249 & 12680 & 11925 & 6673 & 15384 & 16016 & 9587 \\
\hline Remunerações & 10114 & 973 & 1269 & 2770 & 727 & 451 & 4588 & 5248 & 1545 & 1151 & 1347 & 3447 & 2731 \\
\hline Salários & 8539 & 720 & 573 & 2034 & 483 & 331 & 3521 & 3847 & 1154 & 850 & 982 & 2550 & 2137 \\
\hline Contribuições sociais efetivas & 1575 & 253 & 696 & 736 & 244 & 120 & 1067 & 1400 & 392 & 301 & 365 & 897 & 594 \\
\hline Previdência oficial/FGTS & 1570 & 186 & 210 & 690 & 163 & 111 & 1034 & 1365 & 361 & 266 & 330 & 858 & 581 \\
\hline Previdência privada & 5 & 67 & 486 & 46 & 81 & 9 & 33 & 35 & 30 & 34 & 35 & 39 & 13 \\
\hline Contribuições sociais fictícias & 0 & 0 & 0 & 0 & 0 & 0 & 0 & 0 & 0 & 0 & 0 & 0 & 0 \\
\hline Excedente operacional bruto (EOB) & 61314 & 2570 & 7406 & 4846 & 4996 & 2014 & 2491 & 10500 & 1512 & 3190 & 3215 & 2059 & 3425 \\
\hline Rendimento de autônomos & 329 & 113 & 0 & 45 & 0 & 0 & 407 & 0 & 0 & 0 & 0 & 0 & 625 \\
\hline EOB Exclusive rendimento de autônomos & 60985 & 2457 & 7406 & 4801 & 4996 & 2014 & 2084 & 10500 & 1512 & 3190 & 3215 & 2059 & 2800 \\
\hline Valor adicionado a custo de fatores & 71427 & 3543 & 8675 & 7616 & 5724 & 2465 & 7080 & 15748 & 3057 & 4341 & 4562 & 5506 & 6156 \\
\hline Outros impostos sobre a produção & 3 & 413 & 650 & 1013 & 1449 & 660 & 1133 & 1471 & 753 & 553 & 992 & 1094 & 657 \\
\hline Outros subsídios à produção & (-) 1014 & 0 & 0 & 0 & 0 & 0 & $(-) 0$ & (-) 142 & (-) 52 & 0 & 0 & (-) 334 & 0 \\
\hline Valor adicionado a preço básico & 70417 & 3956 & 9325 & 8628 & 7172 & 3125 & 8213 & 17076 & 3758 & 4893 & 5554 & 6266 & 6813 \\
\hline Valor da produção & 125682 & 9100 & 13734 & 21544 & 31179 & 14138 & 25462 & 29756 & 15684 & 11566 & 20939 & 22282 & 16401 \\
\hline Pessoal ocupado & 14363 & 190 & 37 & 430 & 64 & 49 & 615 & 381 & 120 & 89 & 73 & 207 & 812 \\
\hline
\end{tabular}


ANEXO D - Matriz de insumo-produto do Brasil do ano de 1999, valores nominais em milhões de $\mathrm{R} \$$ (metodologia tradicional).

\begin{tabular}{|c|c|c|c|c|c|c|c|c|c|c|c|c|c|c|}
\hline Setores & 14 & 15 & 16 & 17 & 18 & 19 & 20 & 21 & 22 & 23 & 24 & 25 & 26 & 27 \\
\hline 1 Agropecuária & 683 & 378 & 2743 & 0 & 163 & 35 & 0 & 1454 & 5 & 41 & 4895 & 11078 & 14500 & 3255 \\
\hline 2 Extrativa Mineral & 48 & 6 & 210 & 22 & 166 & 26 & 0 & 1 & 0 & 4 & 0 & 3 & 8 & 0 \\
\hline 3 Petróleo e gás & 0 & 0 & 1 & 13422 & 4 & 0 & 0 & 0 & 0 & 0 & 0 & 0 & 0 & 0 \\
\hline 4 Minerais não-metálicos & 48 & 5 & 128 & 68 & 103 & 239 & 21 & 3 & 1 & 4 & 20 & 143 & 5 & 7 \\
\hline 5 Siderurgia & 7 & 3 & 14 & 131 & 259 & 9 & 2 & 3 & 1 & 1 & 0 & 6 & 4 & 2 \\
\hline 6 Metalurgia de não-ferrosos & 101 & 1 & 34 & 11 & 79 & 4 & 1 & 1 & 0 & 1 & 0 & 2 & 2 & 1 \\
\hline 7 Outros Produtos Metalúrgicos & 122 & 79 & 123 & 231 & 217 & 105 & 41 & 79 & 35 & 33 & 13 & 263 & 148 & 81 \\
\hline 8 Máquinas e Equipamentos & 409 & 77 & 417 & 593 & 118 & 77 & 74 & 233 & 23 & 32 & 12 & 116 & 95 & 31 \\
\hline 9 Material Elétrico & 14 & 6 & 25 & 21 & 10 & 4 & 5 & 9 & 1 & 2 & 1 & 7 & 5 & 2 \\
\hline 10 Equipamentos Eletrônicos & 12 & 2 & 11 & 14 & 5 & 3 & 3 & 8 & 1 & 2 & 1 & 5 & 4 & 1 \\
\hline 11 Automóveis, caminhões e ônibus & 9 & 2 & 8 & 10 & 3 & 2 & 2 & 5 & 1 & 1 & 0 & 4 & 4 & 1 \\
\hline 12 Peças e outros veículos & 10 & 10 & 10 & 14 & 6 & 4 & 3 & 6 & 1 & 3 & 1 & 6 & 4 & 2 \\
\hline 13 Madeira e Mobiliário & 158 & 5 & 3 & 8 & 53 & 5 & 15 & 14 & 7 & 29 & 1 & 62 & 25 & 2 \\
\hline 14 Celulose, Papel e Gráfica & 7052 & 22 & 50 & 325 & 197 & 522 & 188 & 133 & 87 & 160 & 65 & 451 & 162 & 82 \\
\hline 15 Indústria da Borracha & 48 & 1595 & 34 & 29 & 33 & 15 & 20 & 48 & 14 & 229 & 1 & 11 & 9 & 3 \\
\hline 16 Elementos Químicos & 464 & 42 & 675 & 1172 & 1986 & 611 & 42 & 77 & 2 & 36 & 1 & 16 & 11 & 2 \\
\hline 17 Refino de Petróleo & 728 & 1157 & 680 & 15677 & 3336 & 679 & 3167 & 1469 & 81 & 231 & 60 & 265 & 136 & 73 \\
\hline 18 Químicos Diversos & 1002 & 232 & 141 & 555 & 3917 & 627 & 287 & 426 & 14 & 182 & 4 & 44 & 25 & 12 \\
\hline 19 Farmacêuticos e Veterinários & 13 & 4 & 18 & 22 & 111 & 880 & 3 & 4 & 1 & 4 & 0 & 6 & 11 & 2 \\
\hline 20 Artigos Plásticos & 98 & 15 & 21 & 64 & 216 & 264 & 542 & 127 & 60 & 253 & 20 & 134 & 213 & 142 \\
\hline 21 Indústria Têxtil & 56 & 265 & 7 & 41 & 25 & 11 & 99 & 7115 & 4036 & 108 & 21 & 83 & 12 & 3 \\
\hline 22 Artigos do Vestuário & 4 & 5 & 2 & 7 & 2 & 2 & 2 & 13 & 22 & 5 & 1 & 3 & 2 & 1 \\
\hline 23 Calçados & 4 & 9 & 1 & 1 & 12 & 2 & 4 & 8 & 60 & 791 & 0 & 1 & 24 & 1 \\
\hline 24 Indústria do Café & 1 & 0 & 0 & 1 & 0 & 1 & 0 & 0 & 0 & 0 & 1870 & 4 & 1 & 0 \\
\hline 25 Beneficiamento de Produtos Vegetais & 52 & 2 & 5 & 5 & 35 & 43 & 1 & 9 & 1 & 1 & 6 & 679 & 49 & 46 \\
\hline 26 Abate de Animais & 5 & 2 & 6 & 1 & 4 & 35 & 0 & 3 & 0 & 377 & 0 & 47 & 2082 & 0 \\
\hline 27 Indústria de Laticínios & 2 & 1 & 0 & 2 & 4 & 13 & 1 & 1 & 1 & 2 & 0 & 15 & 8 & 1439 \\
\hline 28 Fabricação de Açúcar & 2 & 0 & 491 & 2 & 16 & 19 & 0 & 1 & 0 & 0 & 0 & 122 & 1 & 35 \\
\hline 29 Fabricação de Óleos Vegetais & 3 & 1 & 159 & 43 & 339 & 1069 & 1 & 6 & 1 & 1 & 0 & 116 & 9 & 36 \\
\hline 30 Outros Produtos Alimentares & 13 & 3 & 10 & 8 & 17 & 26 & 3 & 9 & 5 & 6 & 3 & 48 & 136 & 20 \\
\hline 31 Indústrias Diversas & 230 & 16 & 38 & 49 & 49 & 17 & 19 & 22 & 16 & 12 & 10 & 13 & 12 & 10 \\
\hline 32 Serviços Industriais de Utilidade Pública & 975 & 108 & 903 & 1037 & 163 & 116 & 224 & 474 & 88 & 98 & 47 & 302 & 304 & 93 \\
\hline 33 Construção Civil & 78 & 8 & 47 & 100 & 31 & 30 & 16 & 27 & 10 & 10 & 7 & 26 & 44 & 13 \\
\hline 34 Comércio & 1840 & 446 & 375 & 1696 & 972 & 1140 & 417 & 1127 & 521 & 435 & 298 & 1903 & 1449 & 334 \\
\hline 35 Supermercados & 0 & 0 & 0 & 0 & 0 & 0 & 0 & 0 & 0 & 0 & 0 & 0 & 0 & 0 \\
\hline 36 Transportes & 462 & 107 & 322 & 2062 & 524 & 409 & 114 & 324 & 76 & 108 & 98 & 460 & 694 & 155 \\
\hline 37 Comunicações & 608 & 56 & 108 & 387 & 225 & 228 & 120 & 155 & 99 & 69 & 66 & 164 & 207 & 62 \\
\hline 38 Instituiçōes Financeiras & 360 & 40 & 262 & 782 & 358 & 8 & 56 & 234 & 33 & 29 & 47 & 173 & 244 & 52 \\
\hline 39 Serviços Prestados às Famílias & 72 & 15 & 24 & 54 & 34 & 38 & 17 & 48 & 37 & 12 & 12 & 40 & 40 & 16 \\
\hline 40 Serviços Prestados às Empresas & 549 & 63 & 109 & 403 & 158 & 658 & 102 & 139 & 142 & 84 & 82 & 304 & 273 & 106 \\
\hline 41 Aluguel de Imóveis & 188 & 15 & 16 & 74 & 54 & 63 & 48 & 58 & 67 & 22 & 14 & 46 & 57 & 15 \\
\hline 42 Administração Pública & 961 & 18 & 27 & 115 & 160 & 207 & 40 & 45 & 34 & 34 & 21 & 187 & 67 & 27 \\
\hline 43 Serviços Privados não-mercantis & 0 & 0 & 0 & 0 & 0 & 0 & 0 & 0 & 0 & 0 & 0 & 0 & 0 & 0 \\
\hline Produção nacional & 17492 & 4819 & 8257 & 39259 & 14163 & 8244 & 5698 & 13918 & 5585 & 3450 & 7700 & 17358 & 21085 & 6167 \\
\hline Importação & 1664 & 670 & 877 & 8277 & 2692 & 1177 & 999 & 2023 & 441 & 342 & 64 & 1489 & 329 & 263 \\
\hline Imposto de importação & 109 & 70 & 59 & 536 & 179 & 76 & 104 & 178 & 51 & 31 & 3 & 39 & 15 & 9 \\
\hline ICM nacional e importado & 1015 & 360 & 296 & 802 & 369 & 417 & 167 & 468 & 454 & 259 & 131 & 462 & 403 & 689 \\
\hline IPI nacional e importado & 409 & 132 & 61 & 184 & 145 & 153 & 69 & 80 & 24 & 57 & 13 & 138 & 64 & 30 \\
\hline Oiil nacional e importado & 89 & 13 & 65 & 261 & 105 & 9 & 18 & 61 & 9 & 8 & 11 & 65 & 59 & 14 \\
\hline Consumo intermediário & 20779 & 6064 & 9615 & 49319 & 17653 & 10076 & 7055 & 16728 & 6564 & 4148 & 7922 & 19550 & 21955 & 7171 \\
\hline Remunerações & 4240 & 550 & 895 & 1598 & 2439 & 1822 & 2002 & 1542 & 1699 & 1149 & 401 & 1609 & 1344 & 462 \\
\hline Salários & 3169 & 421 & 660 & 740 & 1784 & 1355 & 1467 & 1163 & 1337 & 862 & 321 & 1185 & 1061 & 354 \\
\hline Contribuições sociais efetivas & 1071 & 129 & 234 & 859 & 656 & 467 & 535 & 379 & 362 & 287 & 80 & 424 & 282 & 108 \\
\hline Previdência oficial/FGTS & 1026 & 121 & 221 & 247 & 596 & 425 & 509 & 369 & 362 & 280 & 80 & 383 & 271 & 104 \\
\hline Previdência privada & 45 & 8 & 14 & 612 & 60 & 42 & 26 & 11 & 0 & 7 & 0 & 41 & 11 & 5 \\
\hline Contribuições sociais fictícias & 0 & 0 & 0 & 0 & 0 & 0 & 0 & 0 & 0 & 0 & 0 & 0 & 0 & 0 \\
\hline Excedente operacional bruto (EOB) & 3308 & 1524 & 5821 & 20830 & 4216 & 5308 & 982 & 2001 & 1884 & 1051 & 1950 & 4478 & 2019 & 1223 \\
\hline Rendimento de autônomos & 165 & 0 & 0 & 0 & 0 & 0 & 0 & 4 & 1585 & 31 & 16 & 56 & 46 & 0 \\
\hline EOB Exclusive rendimento de autônomos & 3143 & 1524 & 5821 & 20830 & 4216 & 5308 & 982 & 1997 & 299 & 1020 & 1934 & 4422 & 1974 & 1223 \\
\hline Valor adicionado a custo de fatores & 7548 & 2074 & 6716 & 22428 & 6655 & 7131 & 2984 & 3543 & 3583 & 2200 & 2351 & 6087 & 3363 & 1686 \\
\hline Outros impostos sobre a produção & 1386 & 404 & 808 & 3483 & 1225 & 858 & 527 & 1000 & 328 & 304 & 485 & 1212 & 1197 & 428 \\
\hline Outros subsídios à produção & 0 & 0 & 0 & 0 & 0 & 0 & 0 & 0 & 0 & 0 & 0 & 0 & 0 & 0 \\
\hline Valor adicionado a preço básico & 8934 & 2478 & 7524 & 25911 & 7880 & 7989 & 3511 & 4543 & 3911 & 2504 & 2836 & 7299 & 4560 & 2113 \\
\hline Valor da produção & 29713 & 8542 & 17139 & 75230 & 25533 & 18065 & 10566 & 21271 & 10475 & 6652 & 10758 & 26849 & 26515 & 9284 \\
\hline Pessoal ocupado & 417 & 47 & 57 & 45 & 152 & 119 & 206 & 238 & 1451 & 334 & 71 & 321 & 232 & 57 \\
\hline
\end{tabular}


ANEXO D - Matriz de insumo-produto do Brasil do ano de 1999, valores nominais em milhões de $\mathrm{R} \$$ (metodologia tradicional).

\begin{tabular}{|c|c|c|c|c|c|c|c|c|c|c|c|c|c|c|c|}
\hline Setores & 28 & 29 & 30 & 31 & 32 & 33 & 34 & 35 & 36 & 37 & 38 & 39 & 40 & 41 & 42 \\
\hline 1 Agropecuária & 2004 & 5659 & 4229 & 32 & 18 & 9 & 0 & 0 & 0 & 0 & 0 & 2569 & 0 & 0 & 1927 \\
\hline 2 Extrativa Mineral & 0 & 3 & 120 & 272 & 7 & 401 & 4 & 1 & 1 & 1 & 9 & 3 & 13 & 1 & 16 \\
\hline 3 Petróleo e gás & 0 & 0 & 0 & 1 & 11 & 2 & 1 & 0 & 1 & 0 & 0 & 0 & 0 & 0 & 0 \\
\hline 4 Minerais não-metálicos & 26 & 7 & 405 & 144 & 5 & 12033 & 5 & 1 & 1 & 39 & 2 & 446 & 1 & 0 & 291 \\
\hline 5 Siderurgia & 2 & 6 & 10 & 59 & 1 & 1293 & 6 & 1 & 7 & 4 & 2 & 63 & 1 & 0 & 7 \\
\hline 6 Metalurgia de não-ferrosos & 1 & 3 & 4 & 235 & 1 & 981 & 2 & 0 & 3 & 18 & 1 & 80 & 0 & 0 & 3 \\
\hline 7 Outros Produtos Metalúrgicos & 73 & 298 & 399 & 163 & 52 & 7015 & 102 & 25 & 183 & 236 & 16 & 370 & 47 & 4 & 56 \\
\hline 8 Máquinas e Equipamentos & 324 & 67 & 197 & 76 & 1046 & 1055 & 275 & 58 & 173 & 229 & 47 & 225 & 191 & 80 & 317 \\
\hline 9 Material Elétrico & 10 & 4 & 10 & 41 & 335 & 2471 & 33 & 7 & 17 & 354 & 3 & 183 & 32 & 19 & 149 \\
\hline 10 Equipamentos Eletrônicos & 8 & 3 & 8 & 7 & 12 & 44 & 8 & 1 & 10 & 405 & 2 & 128 & 32 & 1 & 62 \\
\hline 11 Automóveis, caminhões e ônibus & 3 & 3 & 8 & 2 & 91 & 52 & 14 & 2 & 35 & 5 & 5 & 153 & 4 & 2 & 75 \\
\hline 12 Peças e outros veículos & 7 & 4 & 9 & 5 & 20 & 140 & 9 & 2 & 2181 & 79 & 3 & 2770 & 4 & 2 & 469 \\
\hline 13 Madeira e Mobiliário & 6 & 8 & 65 & 90 & 5 & 2591 & 109 & 15 & 44 & 3 & 13 & 212 & 20 & 1 & 127 \\
\hline 14 Celulose, Papel e Gráfica & 97 & 125 & 883 & 252 & 127 & 100 & 1770 & 197 & 211 & 239 & 437 & 444 & 3670 & 18 & 2793 \\
\hline 15 Indústria da Borracha & 21 & 6 & 17 & 38 & 26 & 236 & 1 & 0 & 1475 & 18 & 0 & 1848 & 0 & 0 & 70 \\
\hline 16 Elementos Químicos & 63 & 35 & 187 & 55 & 20 & 129 & 6195 & 0 & 71 & 149 & 1 & 285 & 1 & 0 & 395 \\
\hline 17 Refino de Petróleo & 127 & 172 & 501 & 413 & 765 & 1499 & 19857 & 1 & 10030 & 9 & 33 & 358 & 229 & 4 & 454 \\
\hline 18 Químicos Diversos & 51 & 73 & 388 & 171 & 40 & 1995 & 14 & 0 & 61 & 1 & 1 & 481 & 2 & 0 & 381 \\
\hline 19 Farmacêuticos e Veterinários & 2 & 5 & 134 & 3 & 10 & 6 & 8 & 1 & 4 & 1 & 3 & 824 & 2 & 0 & 892 \\
\hline 20 Artigos Plásticos & 22 & 50 & 296 & 199 & 12 & 2115 & 601 & 67 & 788 & 162 & 5 & 431 & 22 & 60 & 320 \\
\hline 21 Indústria Têxtil & 248 & 234 & 39 & 144 & 13 & 36 & 105 & 12 & 297 & 2 & 15 & 1521 & 22 & 1 & 297 \\
\hline 22 Artigos do Vestuário & 5 & 1 & 3 & 2 & 0 & 11 & 5 & 1 & 7 & 20 & 1 & 16 & 1 & 0 & 54 \\
\hline 23 Calçados & 0 & 2 & 8 & 18 & 0 & 14 & 5 & 1 & 13 & 27 & 0 & 69 & 0 & 0 & 11 \\
\hline 24 Indústria do Café & 0 & 1 & 8 & 0 & 0 & 1 & 2 & 0 & 1 & 0 & 1 & 433 & 0 & 0 & 52 \\
\hline 25 Beneficiamento de Produtos Vegetais & 1 & 244 & 4300 & 1 & 1 & 7 & 6 & 1 & 5 & 1 & 2 & 726 & 1 & 0 & 305 \\
\hline 26 Abate de Animais & 0 & 102 & 222 & 7 & 1 & 2 & 5 & 1 & 3 & 1 & 2 & 1489 & 1 & 0 & 432 \\
\hline 27 Indústria de Laticínios & 0 & 2 & 154 & 1 & 1 & 4 & 4 & 0 & 2 & 1 & 1 & 396 & 1 & 0 & 461 \\
\hline 28 Fabricação de Açúcar & 1219 & 1 & 752 & 0 & 17 & 2 & 33 & 1 & 1 & 1 & 2 & 659 & 1 & 0 & 29 \\
\hline 29 Fabricação de Óleos Vegetais & 1 & 3169 & 2213 & 1 & 1 & 4 & 4 & 0 & 2 & 1 & 1 & 418 & 1 & 0 & 9 \\
\hline 30 Outros Produtos Alimentares & 3 & 15 & 1547 & 11 & 1 & 4 & 90 & 1 & 293 & 3 & 3 & 5175 & 2 & 0 & 207 \\
\hline 31 Indústrias Diversas & 10 & 9 & 27 & 122 & 168 & 406 & 46 & 5 & 58 & 38 & 481 & 143 & 807 & 32 & 870 \\
\hline 32 Serviços Industriais de Utilidade Pública & 240 & 172 & 649 & 99 & 14543 & 212 & 1839 & 216 & 320 & 208 & 400 & 1911 & 481 & 271 & 3248 \\
\hline 33 Construção Civil & 47 & 14 & 45 & 15 & 222 & 5191 & 179 & 119 & 322 & 257 & 0 & 377 & 141 & 4200 & 1193 \\
\hline 34 Comércio & 398 & 939 & 2491 & 461 & 426 & 4172 & 2028 & 123 & 2740 & 403 & 946 & 3648 & 1055 & 42 & 5648 \\
\hline 35 Supermercados & 0 & 0 & 0 & 0 & 0 & 0 & 0 & 0 & 0 & 0 & 0 & 368 & 0 & 0 & \\
\hline 36 Transportes & 225 & 464 & 738 & 150 & 104 & 1553 & 4293 & 80 & 6299 & 153 & 1086 & 854 & 549 & 8 & 1988 \\
\hline 37 Comunicações & 61 & 94 & 318 & 146 & 129 & 461 & 3014 & 349 & 1198 & 327 & 1460 & 1122 & 1611 & 87 & 1462 \\
\hline 38 Instituições Financeiras & 68 & 210 & 290 & 138 & 829 & 504 & 2089 & 403 & 1301 & 535 & 6319 & 564 & 479 & 216 & 1219 \\
\hline 39 Serviços Prestados às Famílias & 32 & 18 & 57 & 20 & 455 & 157 & 965 & 64 & 284 & 622 & 3441 & 1020 & 207 & 6 & 9265 \\
\hline 40 Serviços Prestados às Empresas & 136 & 114 & 605 & 947 & 600 & 1736 & 5923 & 846 & 1484 & 607 & 6269 & 1471 & 2586 & 86 & 11621 \\
\hline 41 Aluguel de Imóveis & 13 & 22 & 191 & 53 & 378 & 159 & 3276 & 498 & 358 & 408 & 1340 & 308 & 424 & 44 & 1145 \\
\hline 42 Administração Pública & 34 & 41 & 236 & 184 & 118 & 303 & 1164 & 159 & 292 & 129 & 1062 & 388 & 880 & 17 & 2274 \\
\hline 43 Serviços Privados não-mercantis & 0 & 0 & 0 & 0 & 0 & 0 & 0 & 0 & 0 & 0 & 0 & 0 & 0 & 0 & \\
\hline Produção nacional & 5590 & 12397 & 22764 & 4778 & 20613 & 49106 & 54091 & 3257 & 30580 & 5697 & 23415 & 34949 & 13522 & 5203 & 50594 \\
\hline Importação & 317 & 499 & 1119 & 716 & 1384 & 4209 & 2323 & 375 & 4180 & 1137 & 2011 & 4072 & 1490 & 106 & 5761 \\
\hline Imposto de importação & 27 & 16 & 58 & 40 & 61 & 416 & 33 & 7 & 187 & 90 & 26 & 285 & 69 & 7 & 155 \\
\hline ICM nacional e importado & 239 & 455 & 1078 & 209 & 2010 & 3960 & 2096 & 144 & 1737 & 320 & 553 & 3237 & 917 & 73 & 1962 \\
\hline IPI nacional e importado & 41 & 67 & 370 & 111 & 136 & 1560 & 439 & 76 & 414 & 161 & 461 & 1240 & 337 & 37 & 1049 \\
\hline Oiil nacional e importado & 17 & 55 & 84 & 34 & 125 & 139 & 474 & 83 & 209 & 132 & 485 & 157 & 112 & 50 & 429 \\
\hline Consumo intermediário & 6231 & 13488 & 25472 & 5888 & 24329 & 59392 & 59457 & 3943 & 37307 & 7537 & 26951 & 43940 & 16447 & 5475 & 59950 \\
\hline Remunerações & 696 & 300 & 3505 & 1187 & 9972 & 9791 & 28328 & 1728 & 12775 & 8723 & 31628 & 31648 & 17603 & 2187 & 139134 \\
\hline Salários & 538 & 232 & 2660 & 886 & 7027 & 7754 & 22074 & 1346 & 9682 & 6595 & 25655 & 24099 & 13239 & 1833 & 86401 \\
\hline Contribuiçôes sociais efetivas & 158 & 68 & 845 & 302 & 2945 & 2037 & 6254 & 381 & 3093 & 2128 & 5973 & 7549 & 4364 & 353 & 6140 \\
\hline Previdência oficial/FGTS & 158 & 68 & 800 & 287 & 2175 & 1984 & 6086 & 371 & 2817 & 1841 & 4844 & 7356 & 4235 & 353 & 6038 \\
\hline Previdência privada & 0 & 0 & 46 & 14 & 770 & 54 & 168 & 10 & 276 & 287 & 1129 & 193 & 129 & 0 & 103 \\
\hline Contribuições sociais fictícias & 0 & 0 & 0 & 0 & 0 & 0 & 0 & 0 & 0 & 0 & 0 & 0 & 0 & 0 & 46593 \\
\hline Excedente operacional bruto (EOB) & 636 & 2686 & 5238 & 2044 & 16349 & 66836 & 25619 & 1265 & 9184 & 17361 & 18975 & 16834 & 14193 & 119055 & \\
\hline Rendimento de autônomos & 0 & 0 & 113 & 113 & 0 & 4677 & 16281 & 484 & 5587 & 0 & 2400 & 13285 & 4029 & 462 & \\
\hline EOB Exclusive rendimento de autônomos & 636 & 2686 & 5125 & 1931 & 16349 & 62159 & 9338 & 781 & 3597 & 17361 & 16575 & 3549 & 10164 & 118592 & \\
\hline Valor adicionado a custo de fatores & 1331 & 2986 & 8743 & 3231 & 26321 & 76627 & 53947 & 2993 & 21960 & 26084 & 50603 & 48482 & 31796 & 121241 & 139134 \\
\hline Outros impostos sobre a produção & 379 & 786 & 1627 & 441 & 2639 & 4789 & 4799 & 309 & 2281 & 1789 & 3968 & 1942 & 1725 & 1271 & 1283 \\
\hline Outros subsídios à produção & 0 & 0 & 0 & 0 & (-) 72 & $(-) 317$ & $(-) 643$ & 0 & (-) 851 & (-) 44 & 0 & $(-) 0$ & 0 & 0 & \\
\hline Valor adicionado a preço básico & 1711 & 3772 & 10370 & 3672 & 28888 & 81100 & 58103 & 3302 & 23390 & 27828 & 54571 & 50424 & 33521 & 122513 & 140417 \\
\hline Valor da produção & 7941 & 17260 & 35841 & 9560 & 53217 & 140492 & 117559 & 7245 & 60697 & 35365 & 81522 & 94364 & 49968 & 127987 & 200367 \\
\hline Pessoal ocupado & 75 & 35 & 665 & 278 & 216 & 3909 & 8654 & 670 & 2384 & 209 & 702 & 9466 & 2454 & 278 & 5654 \\
\hline
\end{tabular}


ANEXO D - Matriz de insumo-produto do Brasil do ano de 1999, valores nominais em milhões de $\mathrm{R} \$$ (metodologia tradicional).

\begin{tabular}{|c|c|c|c|c|c|c|c|c|c|c|}
\hline Setores & 43 & 44 & $\begin{array}{c}\text { Total } \\
\text { da atividade }\end{array}$ & $\begin{array}{l}\text { Formação bruta } \\
\text { de capital fixo }\end{array}$ & $\begin{array}{c}\text { Exportação } \\
\text { de bens e serviços }\end{array}$ & $\begin{array}{l}\text { Variação } \\
\text { de estoque }\end{array}$ & $\begin{array}{l}\text { Consumo do } \\
\text { Governo }\end{array}$ & $\begin{array}{l}\text { Consumo } \\
\text { das famílias }\end{array}$ & $\begin{array}{c}\text { Demanda } \\
\text { final }\end{array}$ & $\begin{array}{c}\text { Demanda } \\
\text { total }\end{array}$ \\
\hline 1 Agropecuária & 56 & 0 & 77373 & 2929 & 4386 & 7905 & 0 & 33088 & 48309 & 125682 \\
\hline 2 Extrativa Mineral & 1 & 0 & 4637 & 11 & 4679 & $(-) 311$ & 0 & 83 & 4462 & 9100 \\
\hline 3 Petróleo e gás & 0 & 0 & 13609 & 0 & 4 & 113 & 0 & 8 & 126 & 13734 \\
\hline 4 Minerais não-metálicos & 11 & 0 & 19441 & 4 & 1074 & $(-) 160$ & 0 & 1186 & 2104 & 21544 \\
\hline 5 Siderurgia & 0 & 0 & 25703 & 8 & 5084 & 303 & 0 & 82 & 5477 & 31179 \\
\hline 6 Metalurgia de não-ferrosos & 0 & 0 & 9988 & 5 & 3142 & 554 & 0 & 448 & 4149 & 14138 \\
\hline 7 Outros Produtos Metalúrgicos & 8 & 0 & 21324 & 845 & 1315 & $(-) 205$ & 0 & 2184 & 4138 & 25462 \\
\hline 8 Máquinas e Equipamentos & 6 & 0 & 12264 & 13198 & 2926 & 125 & 0 & 1242 & 17492 & 29756 \\
\hline 9 Material Elétrico & 2 & 0 & 6049 & 2537 & 1959 & 255 & 0 & 4884 & 9635 & 15684 \\
\hline 10 Equipamentos Eletrônicos & 0 & 0 & 1912 & 3416 & 1987 & $(-) 75$ & 0 & 4326 & 9654 & 11566 \\
\hline 11 Automóveis, caminhões e ônibus & 1 & 0 & 910 & 4509 & 3190 & 286 & 0 & 12044 & 20029 & 20939 \\
\hline 12 Peças e outros veículos & 0 & 0 & 12148 & 1000 & 7018 & 156 & 0 & 1960 & 10133 & 22282 \\
\hline 13 Madeira e Mobiliário & 2 & 0 & 6276 & 1548 & 2407 & (-) 46 & 0 & 6215 & 10125 & 16401 \\
\hline 14 Celulose, Papel e Gráfica & 22 & 0 & 22697 & 47 & 3012 & (-) 90 & 0 & 4047 & 7016 & 29713 \\
\hline 15 Indústria da Borracha & 0 & 0 & 7309 & 1 & 922 & 113 & 0 & 197 & 1233 & 8542 \\
\hline 16 Elementos Químicos & 0 & 0 & 14149 & 3 & 1585 & (-) 1102 & 0 & 2504 & 2990 & 17139 \\
\hline 17 Refino de Petróleo & 22 & 0 & 70107 & $(-) 25$ & 2563 & $(-) 132$ & 0 & 2716 & 5123 & 75230 \\
\hline 18 Químicos Diversos & 0 & 0 & 23152 & 11 & 1170 & 54 & 0 & 1146 & 2381 & 25533 \\
\hline 19 Farmacêuticos e Veterinários & 0 & 0 & 3481 & 3 & 615 & 158 & 0 & 13809 & 14585 & 18065 \\
\hline 20 Artigos Plásticos & 16 & 0 & 9523 & 17 & 350 & $(-) \quad 197$ & 0 & 872 & 1042 & 10566 \\
\hline 21 Indústria Têxtil & 1 & 0 & 15474 & 22 & 1437 & 55 & 0 & 4283 & 5797 & 21271 \\
\hline 22 Artigos do Vestuário & 0 & 0 & 244 & 0 & 108 & 4 & 0 & 10120 & 10231 & 10475 \\
\hline 23 Calçados & 1 & 0 & 1173 & 0 & 2931 & $(-) 99$ & 0 & 2647 & 5480 & 6652 \\
\hline 24 Indústria do Café & 12 & 0 & 2396 & 1 & 3403 & 1880 & 0 & 3078 & 8362 & 10758 \\
\hline 25 Beneficiamento de Produtos Vegetais & 13 & 0 & 6642 & 11 & 3324 & 218 & 0 & 16654 & 20207 & 26849 \\
\hline 26 Abate de Animais & 59 & 0 & 4992 & 17 & 2480 & 52 & 0 & 18973 & 21523 & 26515 \\
\hline 27 Indústria de Laticínios & 12 & 0 & 2547 & 4 & 30 & $(-) 5$ & 0 & 6708 & 6738 & 9284 \\
\hline 28 Fabricação de Açúcar & 15 & 0 & 3442 & 1 & 2747 & $(-) 123$ & 0 & 1874 & 4499 & 7941 \\
\hline 29 Fabricação de Óleos Vegetais & 11 & 0 & 8564 & 4 & 3713 & 36 & 0 & 4945 & 8696 & 17260 \\
\hline 30 Outros Produtos Alimentares & 50 & 0 & 12046 & 9 & 1951 & $(-) \quad 104$ & 0 & 21939 & 23795 & 35841 \\
\hline 31 Indústrias Diversas & 47 & 0 & 4403 & 778 & 944 & (-) 83 & 0 & 3518 & 5157 & 9560 \\
\hline 32 Serviços Industriais de Utilidade Pública & 78 & 0 & 36227 & 4 & 13 & 0 & 0 & 16973 & 16990 & 53217 \\
\hline 33 Construção Civil & 19 & 0 & 13288 & 127164 & 32 & 0 & 0 & 8 & 127203 & 140492 \\
\hline 34 Comércio & 69 & 0 & 53446 & 4194 & 7946 & 786 & 0 & 51187 & 64114 & 117559 \\
\hline 35 Supermercados & 0 & 0 & 368 & 0 & 0 & 0 & 0 & 6877 & 6877 & 7245 \\
\hline 36 Transportes & 24 & 0 & 31188 & 413 & 3922 & 135 & 0 & 25040 & 29509 & 60697 \\
\hline 37 Comunicações & 34 & 0 & 17125 & 48 & 111 & $(-) 5$ & 0 & 18087 & 18240 & 35365 \\
\hline 38 Instituiçōes Financeiras & 1 & 41218 & 62963 & 0 & 462 & 0 & 0 & 18097 & 18559 & 81522 \\
\hline 39 Serviços Prestados às Famílias & 14 & 0 & 17674 & 12 & 2940 & 1 & 0 & 73737 & 76690 & 94364 \\
\hline 40 Serviços Prestados às Empresas & 45 & 0 & 42543 & 1431 & 4721 & 2 & 0 & 1271 & 7425 & 49968 \\
\hline 41 Aluguel de Imóveis & 85 & 0 & 10128 & 0 & 0 & 0 & 0 & 117859 & 117859 & 127987 \\
\hline 42 Administração Pública & 12 & 0 & 10653 & 305 & 1263 & 0 & 185858 & 2288 & 189715 & 200367 \\
\hline 43 Serviços Privados não-mercantis & 0 & 0 & 0 & 0 & 0 & 0 & 0 & 11581 & 11581 & 11581 \\
\hline Produção nacional & 750 & 41218 & 719577 & 164486 & 93868 & 10453 & 185858 & 530784 & 985450 & 1705027 \\
\hline Importação & 50 & 0 & 72275 & 13427 & 0 & 662 & 0 & 28592 & 42682 & 114957 \\
\hline Imposto de importação & 3 & 0 & 4339 & 1379 & 0 & 37 & 0 & 2052 & 3468 & 7806 \\
\hline ICM nacional e importado & 60 & 0 & 33293 & 2716 & 4435 & 112 & 0 & 26481 & 33744 & 67038 \\
\hline IPI nacional e importado & 13 & 0 & 10864 & 2012 & 1637 & 42 & 0 & 7407 & 11099 & 21963 \\
\hline Oiil nacional e importado & 1 & 0 & 4421 & 66 & 207 & 8 & 0 & 2102 & 2383 & 6804 \\
\hline Consumo intermediário & 878 & 41218 & 844769 & 184087 & 100148 & 11314 & 185858 & 597418 & 1078825 & 1923595 \\
\hline Remunerações & 10601 & 0 & 367922 & 0 & 0 & 0 & 0 & 0 & 0 & 367922 \\
\hline Salários & 8994 & 0 & 262615 & 0 & 0 & 0 & 0 & 0 & 0 & 262615 \\
\hline Contribuições sociais efetivas & 1608 & 0 & 58714 & 0 & 0 & 0 & 0 & 0 & 0 & 58714 \\
\hline Previdência oficial/FGTS & 1550 & 0 & 53683 & 0 & 0 & 0 & 0 & 0 & 0 & 53683 \\
\hline Previdência privada & 58 & 0 & 5031 & 0 & 0 & 0 & 0 & 0 & 0 & 5031 \\
\hline Contribuições sociais fictícias & 0 & 0 & 46593 & 0 & 0 & 0 & 0 & 0 & 0 & 46593 \\
\hline Excedente operacional bruto (EOB) & 0 & (-) 41218 & 441189 & 0 & 0 & 0 & 0 & 0 & 0 & 441189 \\
\hline Rendimento de autônomos & 0 & 0 & 50852 & 0 & 0 & 0 & 0 & 0 & 0 & 50852 \\
\hline EOB Exclusive rendimento de autônomos & 0 & (-) 41218 & 390337 & 0 & 0 & 0 & 0 & 0 & 0 & 390337 \\
\hline Valor adicionado a custo de fatores & 10601 & (-) 41218 & 809111 & 0 & 0 & 0 & 0 & 0 & 0 & 809111 \\
\hline Outros impostos sobre a produção & 102 & 0 & 54616 & 0 & 0 & 0 & 0 & 0 & 0 & 54616 \\
\hline Outros subsídios à produção & 0 & 0 & (-) 3469 & 0 & 0 & 0 & 0 & 0 & 0 & (-) 3469 \\
\hline Valor adicionado a preço básico & 10703 & (-) 41218 & 860258 & 0 & 0 & 0 & 0 & 0 & 0 & 860258 \\
\hline Valor da produção & 11581 & 0 & 1705027 & 0 & 0 & 0 & 0 & 0 & 0 & 1705027 \\
\hline Pessoal ocupado & 5593 & 0 & 62419 & 0 & 0 & 0 & 0 & 0 & 0 & 62419 \\
\hline
\end{tabular}


ANEXO E - Matriz de insumo-produto do Brasil do ano de 1995, valores nominais em milhões de $\mathrm{R} \$$ (nova proposta metodológica).

\begin{tabular}{|c|c|c|c|c|c|c|c|c|c|c|c|c|c|}
\hline Setores & 1 & 2 & 3 & 4 & 5 & 6 & 7 & 8 & 9 & 10 & 11 & 12 & 13 \\
\hline 1 Agropecuária & 12191 & 10 & 0 & 96 & 758 & 13 & 5 & 0 & 0 & 1 & 0 & 0 & 1771 \\
\hline 2 Extrativa Mineral & 220 & 542 & 5 & 530 & 642 & 342 & 59 & 0 & 24 & 27 & 1 & 0 & 0 \\
\hline 3 Petróleo e gás & 1 & 0 & 11 & 15 & 106 & 1 & 13 & 0 & 0 & 0 & 0 & 0 & 0 \\
\hline 4 Minerais não-metálicos & 70 & 90 & 44 & 3090 & 184 & 116 & 172 & 135 & 273 & 199 & 160 & 107 & 61 \\
\hline 5 Siderurgia & 4 & 4 & 25 & 202 & 8744 & 59 & 4900 & 1222 & 458 & 118 & 793 & 905 & 54 \\
\hline 6 Metalurgia de não-ferrosos & 2 & 2 & 14 & 2 & 180 & 2335 & 853 & 368 & 1228 & 207 & 112 & 640 & 42 \\
\hline 7 Outros Produtos Metalúrgicos & 119 & 232 & 189 & 162 & 520 & 188 & 1787 & 2171 & 797 & 425 & 659 & 2377 & 249 \\
\hline 8 Máquinas e Equipamentos & 195 & 359 & 196 & 281 & 685 & 207 & 512 & 679 & 730 & 229 & 519 & 867 & 84 \\
\hline 9 Material Elétrico & 9 & 14 & 6 & 13 & 65 & 19 & 58 & 492 & 1321 & 550 & 68 & 148 & 7 \\
\hline 10 Equipamentos Eletrônicos & 5 & 14 & 4 & 20 & 33 & 7 & 16 & 97 & 89 & 988 & 14 & 43 & 5 \\
\hline 11 Automóveis, caminhões e ônibus & 4 & 4 & 3 & 5 & 10 & 5 & 15 & 30 & 9 & 4 & 278 & 117 & 3 \\
\hline 12 Peças e outros veículos & 12 & 12 & 5 & 7 & 18 & 21 & 36 & 357 & 45 & 19 & 4359 & 3088 & 16 \\
\hline 13 Madeira e Mobiliário & 85 & 9 & 5 & 18 & 26 & 22 & 57 & 59 & 56 & 237 & 92 & 111 & 1603 \\
\hline 14 Celulose, Papel e Gráfica & 39 & 33 & 51 & 252 & 66 & 48 & 170 & 105 & 159 & 129 & 59 & 103 & 81 \\
\hline 15 Indústria da Borracha & 3 & 35 & 6 & 43 & 89 & 12 & 55 & 195 & 52 & 21 & 852 & 183 & 42 \\
\hline 16 Elementos Químicos & 129 & 15 & 1 & 163 & 126 & 324 & 65 & 26 & 44 & 14 & 22 & 24 & 20 \\
\hline 17 Refino de Petróleo & 1783 & 332 & 59 & 754 & 341 & 99 & 273 & 199 & 363 & 91 & 130 & 276 & 282 \\
\hline 18 Químicos Diversos & 4965 & 161 & 38 & 253 & 144 & 221 & 212 & 128 & 159 & 39 & 288 & 119 & 303 \\
\hline 19 Farmacêuticos e Veterinários & 236 & 4 & 1 & 3 & 3 & 7 & 2 & 1 & 1 & 1 & 1 & 1 & 3 \\
\hline 20 Artigos Plásticos & 183 & 15 & 7 & 35 & 13 & 19 & 75 & 143 & 335 & 320 & 223 & 183 & 318 \\
\hline 21 Indústria Têxtil & 153 & 14 & 1 & 10 & 7 & 4 & 6 & 32 & 9 & 12 & 54 & 64 & 126 \\
\hline 22 Artigos do Vestuário & 2 & 5 & 3 & 3 & 8 & 2 & 4 & 6 & 3 & 3 & 19 & 4 & 3 \\
\hline 23 Calçados & 20 & 0 & 0 & 1 & 1 & 0 & 2 & 10 & 3 & 2 & 21 & 3 & 23 \\
\hline 24 Indústria do Café & 1 & 0 & 0 & 0 & 0 & 0 & 0 & 0 & 0 & 0 & 0 & 0 & 0 \\
\hline 25 Beneficiamento de Produtos Vegetais & 36 & 1 & 0 & 1 & 2 & 1 & 1 & 1 & 1 & 1 & 1 & 1 & 4 \\
\hline 26 Abate de Animais & 42 & 0 & 0 & 1 & 3 & 0 & 0 & 0 & 0 & 0 & 0 & 0 & 7 \\
\hline 27 Indústria de Laticínios & 3 & 0 & 0 & 0 & 0 & 0 & 1 & 1 & 1 & 1 & 1 & 1 & 1 \\
\hline 28 Fabricação de Açúcar & 4 & 0 & 0 & 1 & 1 & 1 & 1 & 1 & 0 & 0 & 0 & 0 & 0 \\
\hline 29 Fabricação de Óleos Vegetais & 505 & 1 & 0 & 1 & 1 & 1 & 1 & 1 & 1 & 1 & 1 & 1 & 1 \\
\hline 30 Outros Produtos Alimentares & 2684 & 7 & 1 & 7 & 4 & 2 & 7 & 8 & 4 & 3 & 3 & 4 & 8 \\
\hline 31 Indústrias Diversas & 39 & 15 & 22 & 25 & 233 & 131 & 41 & 17 & 18 & 23 & 37 & 28 & 10 \\
\hline 32 Serviços Industriais de Utilidade Pública & 285 & 211 & 141 & 430 & 645 & 445 & 326 & 248 & 108 & 60 & 93 & 176 & 188 \\
\hline 33 Construção Civil & 3 & 23 & 46 & 30 & 26 & 16 & 38 & 50 & 21 & 25 & 26 & 33 & 20 \\
\hline 34 Comércio & 1816 & 202 & 116 & 268 & 443 & 140 & 629 & 599 & 562 & 510 & 543 & 556 & 551 \\
\hline 35 Supermercados & 0 & 0 & 0 & 0 & 0 & 0 & 0 & 0 & 0 & 0 & 0 & 0 & 0 \\
\hline 36 Transportes & 1441 & 322 & 96 & 604 & 671 & 180 & 291 & 236 & 214 & 225 & 436 & 161 & 293 \\
\hline 37 Comunicações & 17 & 31 & 25 & 76 & 82 & 39 & 87 & 153 & 81 & 105 & 75 & 67 & 59 \\
\hline 38 Instituições Financeiras & 371 & 191 & 174 & 143 & 294 & 131 & 147 & 113 & 165 & 178 & 248 & 166 & 42 \\
\hline 39 Serviços Prestados às Famílias & 205 & 72 & 56 & 91 & 97 & 27 & 66 & 128 & 57 & 63 & 83 & 49 & 74 \\
\hline 40 Serviços Prestados às Empresas & 480 & 172 & 221 & 84 & 97 & 32 & 89 & 142 & 136 & 154 & 210 & 103 & 61 \\
\hline 41 Aluguel de Imóveis & 12 & 54 & 21 & 71 & 25 & 22 & 83 & 85 & 56 & 59 & 23 & 39 & 63 \\
\hline 42 Administração Pública & 504 & 57 & 71 & 74 & 62 & 26 & 58 & 63 & 67 & 67 & 126 & 88 & 59 \\
\hline 43 Serviços Privados não-mercantis & 0 & 0 & 0 & 0 & 0 & 0 & 0 & 0 & 0 & 0 & 0 & 0 & 0 \\
\hline Produção nacional & 28876 & 3265 & 1664 & 7863 & 15457 & 5265 & 11214 & 8303 & 7650 & 5113 & 10629 & 10839 & 6537 \\
\hline Importação & 932 & 113 & 57 & 286 & 1307 & 1059 & 392 & 966 & 666 & 2921 & 2357 & 738 & 165 \\
\hline Imposto de importação & 53 & 6 & 3 & 15 & 22 & 40 & 28 & 75 & 53 & 201 & 178 & 55 & 13 \\
\hline ICM nacional & 1581 & 3 & 5 & 25 & 6 & 5 & 17 & 10 & 15 & 12 & 6 & 10 & 8 \\
\hline ICM importado & 30 & 0 & 0 & 0 & 0 & 0 & 0 & 0 & 0 & 0 & 0 & 0 & 0 \\
\hline IPI nacional & 161 & 13 & 14 & 23 & 14 & 6 & 18 & 20 & 19 & 18 & 22 & 14 & 12 \\
\hline IPI importado & 52 & 1 & 0 & 0 & 1 & 0 & 0 & 1 & 0 & 0 & 1 & 1 & 0 \\
\hline Outros impostos indiretos líquidos nacional & 96 & 45 & 39 & 37 & 67 & 29 & 33 & 24 & 36 & 39 & 55 & 37 & 9 \\
\hline Outros impostos indiretos líquidos importado & 24 & 1 & 1 & 5 & 43 & 20 & 7 & 17 & 12 & 44 & 48 & 14 & 3 \\
\hline Consumo intermediário & 31805 & 3447 & 1783 & 8254 & 16917 & 6424 & 11708 & 9416 & 8451 & 8349 & 13294 & 11707 & 6746 \\
\hline Remunerações & 7094 & 818 & 478 & 1666 & 755 & 384 & 3774 & 4237 & 1430 & 1147 & 1041 & 2721 & 1916 \\
\hline Salários & 6483 & 638 & 314 & 1398 & 538 & 317 & 3211 & 3565 & 1204 & 964 & 850 & 2281 & 1672 \\
\hline Contribuições sociais efetivas & 611 & 180 & 164 & 268 & 217 & 67 & 564 & 673 & 226 & 183 & 191 & 440 & 244 \\
\hline Previdência oficial/FGTS & 607 & 99 & 61 & 252 & 104 & 61 & 557 & 667 & 214 & 171 & 157 & 423 & 241 \\
\hline Previdência privada & 4 & 81 & 103 & 17 & 114 & 6 & 7 & 5 & 12 & 12 & 34 & 17 & 3 \\
\hline Contribuições sociais fictícias & 0 & 0 & 0 & 0 & 0 & 0 & 0 & 0 & 0 & 0 & 0 & 0 & 0 \\
\hline Excedente operacional bruto (EOB) & 46327 & 1479 & 1836 & 4409 & 4080 & 2096 & 2954 & 7262 & 2321 & 4395 & 3839 & 3186 & 2799 \\
\hline Rendimento de autônomos & 255 & 106 & 0 & 44 & 0 & 0 & 268 & 0 & 0 & 0 & 0 & 0 & 510 \\
\hline EOB Exclusive rendimento de autônomos & 46072 & 1373 & 1836 & 4365 & 4080 & 2096 & 2686 & 7262 & 2321 & 4395 & 3839 & 3186 & 2289 \\
\hline Valor adicionado a custo de fatores & 53421 & 2297 & 2315 & 6075 & 4835 & 2480 & 6729 & 11500 & 3751 & 5542 & 4880 & 5906 & 4716 \\
\hline Outros impostos sobre a produção & 2 & 196 & 138 & 488 & 689 & 286 & 672 & 774 & 417 & 460 & 590 & 622 & 398 \\
\hline Outros subsídios à produção & (-) 1930 & 0 & 0 & 0 & 0 & 0 & $(-) 0$ & $(-) 6$ & $(-) 3$ & 0 & 0 & $(-) 17$ & 0 \\
\hline Valor adicionado a preço básico & 51493 & 2493 & 2452 & 6564 & 5524 & 2766 & 7400 & 12267 & 4165 & 6002 & 5471 & 6511 & 5114 \\
\hline Valor da produção & 83300 & 5949 & 4233 & 14802 & 22389 & 9188 & 19119 & 21866 & 12632 & 14338 & 18762 & 18234 & 11856 \\
\hline Pessoal ocupado & 15163 & 230 & 31 & 444 & 96 & 56 & 612 & 422 & 153 & 123 & 88 & 236 & 843 \\
\hline
\end{tabular}


ANEXO E - Matriz de insumo-produto do Brasil do ano de 1995, valores nominais em milhões de $\mathrm{R} \$$ (nova proposta metodológica).

\begin{tabular}{|c|c|c|c|c|c|c|c|c|c|c|c|c|c|c|}
\hline Setores & 14 & 15 & 16 & 17 & 18 & 19 & 20 & 21 & 22 & 23 & 24 & 25 & 26 & 27 \\
\hline 1 Agropecuária & 475 & 276 & 2207 & 0 & 113 & 24 & 0 & 814 & 4 & 43 & 2185 & 8061 & 8765 & 3334 \\
\hline 2 Extrativa Mineral & 40 & 6 & 172 & 16 & 80 & 21 & 0 & 1 & 0 & 4 & 0 & 3 & 6 & 0 \\
\hline 3 Petróleo e gás & 0 & 0 & 0 & 4094 & 14 & 0 & 0 & 0 & 0 & 0 & 0 & 0 & 0 & 0 \\
\hline 4 Minerais não-metálicos & 39 & 4 & 105 & 50 & 65 & 189 & 18 & 2 & 1 & 4 & 12 & 125 & 4 & 6 \\
\hline 5 Siderurgia & 5 & 2 & 9 & 76 & 166 & 6 & 1 & 2 & 1 & 1 & 0 & 5 & 2 & 1 \\
\hline 6 Metalurgia de não-ferrosos & 70 & 1 & 24 & 7 & 55 & 2 & 0 & 1 & 0 & 0 & 0 & 2 & 1 & 1 \\
\hline 7 Outros Produtos Metalúrgicos & 103 & 73 & 105 & 177 & 179 & 83 & 36 & 76 & 36 & 35 & 8 & 231 & 115 & 74 \\
\hline 8 Máquinas e Equipamentos & 369 & 78 & 396 & 496 & 111 & 67 & 72 & 245 & 26 & 35 & 7 & 109 & 78 & 31 \\
\hline 9 Material Elétrico & 13 & 6 & 26 & 18 & 10 & 3 & 5 & 10 & 1 & 2 & 1 & 6 & 4 & 2 \\
\hline 10 Equipamentos Eletrônicos & 13 & 2 & 14 & 13 & 5 & 3 & 3 & 11 & 1 & 2 & 1 & 6 & 4 & 1 \\
\hline 11 Automóveis, caminhões e ônibus & 5 & 1 & 5 & 6 & 2 & 1 & 1 & 3 & 1 & 1 & 0 & 3 & 2 & 1 \\
\hline 12 Peças e outros veículos & 9 & 10 & 9 & 11 & 5 & 3 & 3 & 6 & 1 & 3 & 0 & 5 & 3 & 2 \\
\hline 13 Madeira e Mobiliário & 133 & 3 & 2 & 6 & 44 & 4 & 13 & 12 & 8 & 31 & 1 & 39 & 19 & 2 \\
\hline 14 Celulose, Papel e Gráfica & 4527 & 16 & 33 & 196 & 129 & 330 & 129 & 101 & 71 & 132 & 30 & 315 & 100 & 60 \\
\hline 15 Indústria da Borracha & 44 & 1573 & 31 & 24 & 29 & 13 & 19 & 50 & 16 & 281 & 1 & 11 & 7 & 3 \\
\hline 16 Elementos Químicos & 317 & 30 & 375 & 700 & 1315 & 394 & 30 & 58 & 1 & 31 & 1 & 12 & 7 & 2 \\
\hline 17 Refino de Petróleo & 469 & 775 & 426 & 8288 & 2070 & 404 & 2242 & 1060 & 67 & 190 & 27 & 182 & 83 & 52 \\
\hline 18 Químicos Diversos & 760 & 155 & 101 & 284 & 1906 & 332 & 217 & 292 & 12 & 157 & 2 & 30 & 15 & 9 \\
\hline 19 Farmacêuticos e Veterinários & 9 & 2 & 12 & 12 & 71 & 28 & 2 & 3 & 1 & 3 & 0 & 4 & 6 & 2 \\
\hline 20 Artigos Plásticos & 74 & 12 & 16 & 44 & 162 & 191 & 425 & 111 & 57 & 239 & 11 & 107 & 150 & 119 \\
\hline 21 Indústria Têxtil & 46 & 240 & 6 & 32 & 21 & 8 & 78 & 5679 & 3811 & 105 & 12 & 74 & 9 & 3 \\
\hline 22 Artigos do Vestuário & 5 & 5 & 3 & 9 & 2 & 3 & 2 & 13 & 24 & 5 & 1 & 3 & 3 & 1 \\
\hline 23 Calçados & 4 & 9 & 1 & 0 & 11 & 2 & 3 & 9 & 75 & 870 & 0 & 1 & 19 & 1 \\
\hline 24 Indústria do Café & 1 & 0 & 0 & 0 & 0 & 1 & 0 & 0 & 0 & 0 & 1384 & 3 & 0 & 0 \\
\hline 25 Beneficiamento de Produtos Vegetais & 42 & 1 & 3 & 2 & 27 & 27 & 1 & 8 & 1 & 1 & 4 & 576 & 38 & 40 \\
\hline 26 Abate de Animais & 3 & 1 & 5 & 0 & 3 & 28 & 0 & 2 & 0 & 434 & 0 & 30 & 1667 & 0 \\
\hline 27 Indústria de Laticínios & 1 & 0 & 0 & 1 & 3 & 8 & 0 & 1 & 0 & 1 & 0 & 14 & 6 & 1483 \\
\hline 28 Fabricação de Açúcar & 1 & 0 & 409 & 1 & 13 & 14 & 0 & 1 & 0 & 0 & 0 & 106 & 0 & 32 \\
\hline 29 Fabricação de Óleos Vegetais & 2 & 0 & 93 & 23 & 194 & 581 & 0 & 5 & 1 & 1 & 0 & 71 & 5 & 23 \\
\hline 30 Outros Produtos Alimentares & 9 & 2 & 7 & 4 & 11 & 16 & 2 & 8 & 4 & 5 & 2 & 35 & 92 & 16 \\
\hline 31 Indústrias Diversas & 235 & 17 & 40 & 47 & 48 & 15 & 19 & 26 & 21 & 14 & 6 & 13 & 12 & 11 \\
\hline 32 Serviços Industriais de Utilidade Pública & 495 & 60 & 467 & 484 & 83 & 59 & 119 & 279 & 57 & 63 & 17 & 164 & 146 & 53 \\
\hline 33 Construção Civil & 53 & 6 & 33 & 63 & 21 & 19 & 11 & 21 & 8 & 9 & 4 & 19 & 28 & 10 \\
\hline 34 Comércio & 1075 & 146 & 193 & 495 & 400 & 539 & 193 & 711 & 366 & 183 & 94 & 1055 & 600 & 128 \\
\hline 35 Supermercados & 0 & 0 & 0 & 0 & 0 & 0 & 0 & 0 & 0 & 0 & 0 & 0 & 0 & 0 \\
\hline 36 Transportes & 332 & 86 & 218 & 1318 & 368 & 275 & 83 & 211 & 69 & 103 & 60 & 356 & 454 & 128 \\
\hline 37 Comunicações & 186 & 18 & 34 & 105 & 67 & 64 & 37 & 53 & 37 & 26 & 14 & 51 & 57 & 21 \\
\hline 38 Instituições Financeiras & 205 & 25 & 152 & 408 & 203 & 5 & 34 & 155 & 24 & 21 & 19 & 105 & 130 & 33 \\
\hline 39 Serviços Prestados às Famílias & 120 & 23 & 45 & 75 & 48 & 39 & 26 & 66 & 50 & 20 & 14 & 67 & 63 & 32 \\
\hline 40 Serviços Prestados às Empresas & 243 & 31 & 49 & 163 & 70 & 280 & 47 & 72 & 79 & 46 & 26 & 143 & 113 & 52 \\
\hline 41 Aluguel de Imóveis & 154 & 13 & 14 & 56 & 44 & 49 & 41 & 55 & 69 & 23 & 8 & 40 & 44 & 14 \\
\hline 42 Administração Pública & 897 & 17 & 24 & 89 & 128 & 142 & 37 & 45 & 35 & 39 & 13 & 184 & 52 & 26 \\
\hline 43 Serviços Privados não-mercantis & 0 & 0 & 0 & 0 & 0 & 0 & 0 & 0 & 0 & 0 & 0 & 0 & 0 & 0 \\
\hline Produção nacional & 11582 & 3724 & 5864 & 17891 & 8297 & 4269 & 3951 & 10275 & 5039 & 3163 & 3962 & 12367 & 12909 & 5807 \\
\hline Importação & 1129 & 508 & 372 & 4995 & 1752 & 992 & 435 & 1470 & 359 & 275 & 8 & 722 & 94 & 121 \\
\hline Imposto de importação & 35 & 35 & 16 & 455 & 66 & 50 & 24 & 69 & 51 & 38 & 0 & 21 & 4 & 15 \\
\hline ICM nacional & 0 & 2 & 3 & 19 & 12 & 32 & 12 & 10 & 7 & 13 & 3 & 31 & 10 & 6 \\
\hline ICM importado & 0 & 0 & 0 & 0 & 0 & 0 & 0 & 0 & 0 & 0 & 0 & 0 & 0 & 0 \\
\hline IPI nacional & 22 & 4 & 7 & 33 & 15 & 35 & 12 & 16 & 10 & 11 & 4 & 27 & 16 & 8 \\
\hline IPI importado & 1 & 0 & 0 & 1 & 0 & 1 & 0 & 0 & 0 & 0 & 0 & 1 & 0 & 0 \\
\hline Outros impostos indiretos líquidos nacional & 45 & 6 & 35 & 113 & 45 & 1 & 7 & 34 & 5 & 4 & 4 & 23 & 29 & 8 \\
\hline Outros impostos indiretos líquidos importado & 18 & 11 & 9 & 116 & 45 & 19 & 8 & 25 & 5 & 4 & 0 & 25 & 1 & 2 \\
\hline Consumo intermediário & 12832 & 4290 & 6306 & 23624 & 10233 & 5398 & 4450 & 11899 & 5476 & 3509 & 3982 & 13216 & 13063 & 5966 \\
\hline Remuneraçōes & 2729 & 504 & 762 & 1429 & 1687 & 1323 & 1064 & 1312 & 1451 & 941 & 276 & 1171 & 1013 & 343 \\
\hline Salários & 2315 & 424 & 643 & 967 & 1424 & 1102 & 890 & 1104 & 1264 & 798 & 240 & 980 & 869 & 288 \\
\hline Contribuições sociais efetivas & 414 & 79 & 118 & 462 & 263 & 221 & 174 & 208 & 187 & 142 & 36 & 190 & 145 & 55 \\
\hline Previdência oficial/FGTS & 402 & 74 & 110 & 166 & 244 & 200 & 170 & 206 & 187 & 141 & 36 & 169 & 137 & 53 \\
\hline Previdência privada & 12 & 5 & 8 & 297 & 19 & 21 & 4 & 3 & 0 & 1 & 0 & 21 & 8 & 2 \\
\hline Contribuições sociais fictícias & 0 & 0 & 0 & 0 & 0 & 0 & 0 & 0 & 0 & 0 & 0 & 0 & 0 & 0 \\
\hline Excedente operacional bruto (EOB) & 3048 & 1434 & 3628 & 13071 & 2354 & 2759 & 2038 & 3072 & 1684 & 804 & 1002 & 2480 & 1868 & 989 \\
\hline Rendimento de autônomos & 253 & 0 & 0 & 0 & 0 & 0 & 0 & 7 & 1467 & 9 & 8 & 28 & 23 & 0 \\
\hline EOB Exclusive rendimento de autônomos & 2795 & 1434 & 3628 & 13071 & 2354 & 2759 & 2038 & 3065 & 217 & 795 & 994 & 2451 & 1844 & 989 \\
\hline Valor adicionado a custo de fatores & 5777 & 1937 & 4390 & 14501 & 4041 & 4082 & 3103 & 4384 & 3135 & 1745 & 1278 & 3651 & 2881 & 1332 \\
\hline Outros impostos sobre a produção & 645 & 206 & 350 & 1209 & 485 & 329 & 264 & 539 & 300 & 186 & 168 & 552 & 518 & 235 \\
\hline Outros subsídios à produção & (-) 49 & 0 & 0 & 0 & 0 & 0 & 0 & (-) 62 & 0 & $(-) 51$ & (-) 39 & 0 & 0 & 0 \\
\hline Valor adicionado a preço básico & 6372 & 2143 & 4740 & 15709 & 4526 & 4412 & 3367 & 4860 & 3435 & 1880 & 1407 & 4202 & 3398 & 1567 \\
\hline Valor da produção & 19129 & 6428 & 11041 & 39343 & 14741 & 9805 & 7805 & 16755 & 8908 & 5384 & 5389 & 17413 & 16457 & 7531 \\
\hline Pessoal ocupado & 434 & 67 & 78 & 68 & 159 & 129 & 165 & 308 & 1644 & 361 & 76 & 324 & 253 & 67 \\
\hline
\end{tabular}


ANEXO E - Matriz de insumo-produto do Brasil do ano de 1995, valores nominais em milhões de R \$ (nova proposta metodológica).

\begin{tabular}{|c|c|c|c|c|c|c|c|c|c|c|c|c|c|c|c|}
\hline Setores & 28 & 29 & 30 & 31 & 32 & 33 & 34 & 35 & 36 & 37 & 38 & 39 & 40 & 41 & 42 \\
\hline 1 Agropecuária & 1629 & 4239 & 2865 & 22 & 8 & 6 & 0 & 3186 & 0 & 0 & 0 & 1587 & 0 & 0 & 1595 \\
\hline 2 Extrativa Mineral & 0 & 3 & 105 & 212 & 3 & 298 & 3 & 5 & 1 & 0 & 7 & 2 & 7 & 0 & 14 \\
\hline 3 Petróleo e gás & 0 & 0 & 0 & 1 & 11 & 1 & 1 & 0 & 0 & 0 & 0 & 0 & 0 & 0 & 0 \\
\hline 4 Minerais não-metálicos & 19 & 6 & 358 & 111 & 3 & 7025 & 4 & 92 & 1 & 6 & 1 & 223 & 0 & 0 & 195 \\
\hline 5 Siderurgia & 1 & 5 & 8 & 40 & 1 & 586 & 5 & 4 & 5 & 1 & 1 & 33 & 1 & 0 & 5 \\
\hline 6 Metalurgia de não-ferrosos & 1 & 2 & 3 & 155 & 0 & 377 & 2 & 45 & 2 & 3 & 0 & 39 & 0 & 0 & 3 \\
\hline 7 Outros Produtos Metalúrgicos & 54 & 263 & 353 & 133 & 26 & 3736 & 63 & 200 & 115 & 41 & 13 & 207 & 25 & 3 & 48 \\
\hline 8 Máquinas e Equipamentos & 264 & 64 & 186 & 76 & 552 & 824 & 203 & 95 & 141 & 58 & 35 & 160 & 123 & 64 & 294 \\
\hline 9 Material Elétrico & 9 & 3 & 9 & 42 & 332 & 2165 & 29 & 630 & 15 & 86 & 1 & 161 & 24 & 17 & 149 \\
\hline 10 Equipamentos Eletrônicos & 8 & 3 & 8 & 10 & 8 & 36 & 7 & 931 & 9 & 109 & 1 & 122 & 34 & 1 & 66 \\
\hline 11 Automóveis, caminhões e ônibus & 2 & 3 & 6 & 1 & 44 & 30 & 7 & 3 & 29 & 1 & 3 & 123 & 2 & 1 & 73 \\
\hline 12 Peças e outros veículos & 6 & 4 & 8 & 4 & 12 & 100 & 7 & 10 & 1870 & 20 & 1 & 1934 & 3 & 1 & 492 \\
\hline 13 Madeira e Mobiliário & 4 & 5 & 51 & 77 & 2 & 1878 & 80 & 31 & 32 & 1 & 10 & 142 & 11 & 1 & 101 \\
\hline 14 Celulose, Papel e Gráfica & 56 & 88 & 622 & 155 & 53 & 64 & 1124 & 1235 & 138 & 45 & 312 & 267 & 2006 & 12 & 2141 \\
\hline 15 Indústria da Borracha & 17 & 5 & 16 & 32 & 10 & 141 & 1 & 0 & 756 & 3 & 0 & 994 & 0 & 0 & 49 \\
\hline 16 Elementos Químicos & 38 & 25 & 133 & 35 & 9 & 52 & 1826 & 14 & 43 & 28 & 0 & 199 & 0 & 0 & 352 \\
\hline 17 Refino de Petróleo & 72 & 120 & 338 & 269 & 253 & 850 & 6947 & 24 & 3867 & 4 & 29 & 150 & 112 & 2 & 434 \\
\hline 18 Químicos Diversos & 30 & 52 & 273 & 110 & 20 & 656 & 8 & 154 & 37 & 0 & 1 & 250 & 1 & 0 & 337 \\
\hline 19 Farmacêuticos e Veterinários & 1 & 3 & 94 & 2 & 5 & 4 & 6 & 3039 & 2 & 0 & 2 & 444 & 1 & 0 & 28 \\
\hline 20 Artigos Plásticos & 15 & 40 & 239 & 143 & 5 & 1133 & 337 & 162 & 454 & 29 & 4 & 248 & 11 & 35 & 232 \\
\hline 21 Indústria Têxtil & 186 & 187 & 32 & 111 & 6 & 22 & 71 & 146 & 208 & 1 & 12 & 731 & 12 & 1 & 238 \\
\hline 22 Artigos do Vestuário & 5 & 1 & 5 & 2 & 0 & 11 & 4 & 375 & 5 & 4 & 0 & 10 & 1 & 0 & 44 \\
\hline 23 Calçados & 0 & 2 & 8 & 16 & 0 & 7 & 3 & 86 & 7 & 5 & 0 & 44 & 0 & 0 & 9 \\
\hline 24 Indústria do Café & 0 & 1 & 8 & 0 & 0 & 1 & 2 & 555 & 1 & 0 & 0 & 374 & 0 & 0 & 40 \\
\hline 25 Beneficiamento de Produtos Vegetais & 0 & 210 & 3008 & 1 & 0 & 5 & 6 & 3439 & 4 & 0 & 1 & 419 & 1 & 0 & 234 \\
\hline 26 Abate de Animais & 0 & 92 & 192 & 6 & 0 & 2 & 4 & 2494 & 2 & 0 & 1 & 938 & 0 & 0 & 348 \\
\hline 27 Indústria de Laticínios & 0 & 1 & 141 & 0 & 0 & 4 & 4 & 2294 & 2 & 0 & 1 & 271 & 0 & 0 & 393 \\
\hline 28 Fabricação de Açúcar & 879 & 0 & 659 & 0 & 8 & 1 & 12 & 315 & 1 & 0 & 1 & 345 & 0 & 0 & 20 \\
\hline 29 Fabricação de Óleos Vegetais & 0 & 1972 & 1370 & 0 & 0 & 3 & 4 & 1096 & 2 & 0 & 1 & 229 & 0 & 0 & 5 \\
\hline 30 Outros Produtos Alimentares & 2 & 10 & 1223 & 8 & 1 & 4 & 32 & 5190 & 182 & 1 & 2 & 3430 & 1 & 0 & 162 \\
\hline 31 Indústrias Diversas & 8 & 10 & 29 & 348 & 84 & 257 & 29 & 321 & 37 & 9 & 415 & 80 & 435 & 20 & 801 \\
\hline 32 Serviços Industriais de Utilidade Pública & 108 & 94 & 355 & 50 & 6925 & 99 & 743 & 216 & 147 & 60 & 304 & 891 & 187 & 120 & 2657 \\
\hline 33 Construção Civil & 28 & 10 & 33 & 10 & 95 & 3488 & 104 & 104 & 219 & 50 & 0 & 270 & 80 & 2861 & 942 \\
\hline 34 Comércio & 149 & 473 & 1341 & 306 & 141 & 3320 & 1643 & 252 & 1492 & 74 & 462 & 4730 & 372 & 18 & 4114 \\
\hline 35 Supermercados & 0 & 0 & 0 & 0 & 0 & 0 & 0 & 0 & 0 & 0 & 0 & 149 & 0 & 0 & 0 \\
\hline 36 Transportes & 144 & 395 & 578 & 105 & 91 & 964 & 2880 & 815 & 2249 & 151 & 666 & 591 & 309 & 5 & 1555 \\
\hline 37 Comunicações & 16 & 30 & 100 & 61 & 55 & 118 & 629 & 209 & 284 & 12 & 906 & 280 & 337 & 21 & 1139 \\
\hline 38 Instituições Financeiras & 34 & 128 & 178 & 74 & 366 & 282 & 1273 & 204 & 764 & 110 & 4315 & 337 & 229 & 123 & 846 \\
\hline 39 Serviços Prestados às Famílias & 44 & 32 & 100 & 28 & 206 & 299 & 1241 & 78 & 511 & 128 & 1888 & 587 & 266 & 10 & 7692 \\
\hline 40 Serviços Prestados às Empresas & 53 & 54 & 287 & 392 & 413 & 759 & 2691 & 388 & 656 & 304 & 3722 & 688 & 1126 & 38 & 9515 \\
\hline 41 Aluguel de Imóveis & 9 & 19 & 167 & 41 & 193 & 129 & 2757 & 412 & 292 & 138 & 791 & 263 & 290 & 36 & 902 \\
\hline 42 Administração Pública & 26 & 39 & 220 & 151 & 127 & 233 & 947 & 586 & 234 & 92 & 1088 & 316 & 685 & 13 & 3047 \\
\hline 43 Serviços Privados não-mercantis & 0 & 0 & 0 & 0 & 0 & 0 & 0 & 0 & 0 & 0 & 0 & 0 & 0 & 0 & 0 \\
\hline Produção nacional & 3917 & 8695 & 15711 & 3341 & 10072 & 29971 & 25739 & 29437 & 14811 & 1575 & 15000 & 23257 & 6695 & 3406 & 41315 \\
\hline Importação & 82 & 365 & 1000 & 204 & 1055 & 1111 & 736 & 1442 & 3410 & 192 & 444 & 828 & 273 & 20 & 2411 \\
\hline Imposto de importação & 5 & 5 & 48 & 13 & 8 & 96 & 28 & 100 & 126 & 8 & 9 & 64 & 13 & 1 & 79 \\
\hline ICM nacional & 5 & 9 & 61 & 15 & 1200 & 5137 & 1250 & 2460 & 1318 & 79 & 457 & 3282 & 484 & 43 & 1958 \\
\hline ICM importado & 0 & 0 & 0 & 0 & 9 & 153 & 25 & 119 & 193 & 18 & 17 & 103 & 21 & 2 & 161 \\
\hline IPI nacional & 7 & 10 & 50 & 26 & 64 & 1925 & 267 & 1362 & 401 & 37 & 242 & 1078 & 193 & 20 & 842 \\
\hline IPI importado & 0 & 0 & 1 & 1 & 17 & 235 & 21 & 156 & 89 & 13 & 23 & 100 & 26 & 3 & 179 \\
\hline Outros impostos indiretos líquidos nacional & 8 & 29 & 40 & 16 & 49 & 67 & 376 & 120 & 103 & 23 & 207 & 72 & 48 & 27 & 2 \\
\hline Outros impostos indiretos líquidos importado & 1 & 6 & 19 & 3 & 2 & 19 & 7 & 25 & 26 & 2 & 2 & 14 & 3 & 0 & 24 \\
\hline Consumo intermediário & 4027 & 9119 & 16931 & 3619 & 12476 & 38714 & 28450 & 35221 & 20475 & 1946 & 16400 & 28799 & 7757 & 3523 & 46971 \\
\hline Remuneraçōes & 473 & 256 & 2433 & 1077 & 7784 & 6819 & 18010 & 1436 & 9098 & 2903 & 24936 & 18335 & 9858 & 1122 & 92183 \\
\hline Salários & 400 & 216 & 2056 & 916 & 6131 & 5904 & 15480 & 1235 & 7641 & 2369 & 20405 & 15794 & 8386 & 1016 & 60149 \\
\hline Contribuições sociais efetivas & 73 & 40 & 377 & 161 & 1653 & 915 & 2530 & 202 & 1457 & 534 & 4531 & 2541 & 1472 & 106 & 6342 \\
\hline Previdência oficial/FGTS & 73 & 40 & 354 & 158 & 1120 & 903 & 2516 & 201 & 1271 & 335 & 3318 & 2529 & 1466 & 106 & 6280 \\
\hline Previdência privada & 0 & 0 & 23 & 4 & 533 & 12 & 14 & 1 & 186 & 199 & 1213 & 12 & 6 & 0 & 62 \\
\hline Contribuições sociais fictícias & 0 & 0 & 0 & 0 & 0 & 0 & 0 & 0 & 0 & 0 & 0 & 0 & 0 & 0 & 25692 \\
\hline Excedente operacional bruto (EOB) & 419 & 1110 & 3702 & 1965 & 6571 & 43009 & 27154 & 1944 & 9955 & 5451 & 18465 & 21518 & 8448 & 57986 & 0 \\
\hline Rendimento de autônomos & 0 & 0 & 58 & 91 & 0 & 3529 & 11645 & 929 & 3683 & 0 & 1753 & 10340 & 2776 & 346 & 0 \\
\hline EOB Exclusive rendimento de autônomos & 419 & 1110 & 3644 & 1874 & 6571 & 39480 & 15509 & 1015 & 6272 & 5451 & 16712 & 11178 & 5672 & 57640 & 0 \\
\hline Valor adicionado a custo de fatores & 892 & 1367 & 6135 & 3043 & 14355 & 49828 & 45163 & 3380 & 19053 & 8354 & 43401 & 39853 & 18306 & 59108 & 92183 \\
\hline Outros impostos sobre a produção & 166 & 331 & 777 & 227 & 1031 & 2898 & 2701 & 242 & 1427 & 378 & 2455 & 2595 & 1089 & 451 & 1185 \\
\hline Outros subsídios à produção & 0 & 0 & 0 & 0 & $(-) 91$ & $(-) 18$ & (-) 409 & 0 & (-) 851 & (-) 47 & 0 & 0 & 0 & 0 & 0 \\
\hline Valor adicionado a preço básico & 1057 & 1698 & 6912 & 3269 & 15295 & 52708 & 47456 & 3622 & 19628 & 8685 & 45856 & 42448 & 19396 & 59559 & 93368 \\
\hline Valor da produção & 5092 & 10814 & 23830 & 6632 & 27772 & 91348 & 75914 & 38844 & 40072 & 10631 & 62256 & 71208 & 27516 & 63093 & 140339 \\
\hline Pessoal ocupado & 95 & 50 & 670 & 272 & 255 & 3429 & 8216 & 655 & 2265 & 183 & 799 & 8663 & 2032 & 287 & 5320 \\
\hline
\end{tabular}


ANEXO E - Matriz de insumo-produto do Brasil do ano de 1995, valores nominais em milhões de R \$ (nova proposta metodológica).

\begin{tabular}{|c|c|c|c|c|c|c|c|c|c|c|}
\hline Setores & 43 & 44 & $\begin{array}{c}\text { Total } \\
\text { da atividade }\end{array}$ & $\begin{array}{l}\text { Formação bruta } \\
\text { de capital fixo }\end{array}$ & $\begin{array}{c}\text { Exportação } \\
\text { de bens e } \\
\text { serviços } \\
\end{array}$ & $\begin{array}{l}\text { Variação } \\
\text { de estoque }\end{array}$ & $\begin{array}{l}\text { Consumo do } \\
\text { Governo }\end{array}$ & $\begin{array}{c}\text { Consumo } \\
\text { das famílias }\end{array}$ & $\begin{array}{l}\text { Demanda } \\
\text { final }\end{array}$ & $\begin{array}{c}\text { Demanda } \\
\text { total }\end{array}$ \\
\hline 1 Agropecuária & 43 & 0 & 56328 & 2964 & 1363 & 3193 & 0 & 19452 & 26972 & 83300 \\
\hline 2 Extrativa Mineral & 1 & 0 & 3405 & 1 & 2244 & 254 & 0 & 44 & 2544 & 5949 \\
\hline 3 Petróleo e gás & 0 & 0 & 4272 & 0 & 53 & (-) 96 & 0 & 4 & $(-) \quad 39$ & 4233 \\
\hline 4 Minerais não-metálicos & 7 & 0 & 13377 & 6 & 623 & 192 & 0 & 604 & 1426 & 14802 \\
\hline 5 Siderurgia & 0 & 0 & 18462 & 6 & 3653 & 218 & 0 & 51 & 3927 & 22389 \\
\hline 6 Metalurgia de não-ferrosos & 0 & 0 & 6783 & 4 & 2027 & 208 & 0 & 167 & 2405 & 9188 \\
\hline 7 Outros Produtos Metalúrgicos & 6 & 0 & 16492 & 560 & 874 & 117 & 0 & 1076 & 2628 & 19119 \\
\hline 8 Máquinas e Equipamentos & 4 & 0 & 10805 & 8880 & 1985 & (-) 540 & 0 & 737 & 11061 & 21866 \\
\hline 9 Material Elétrico & 2 & 0 & 6553 & 1545 & 1325 & 302 & 0 & 2908 & 6079 & 12632 \\
\hline 10 Equipamentos Eletrônicos & 0 & 0 & 2767 & 4815 & 703 & 207 & 0 & 5845 & 11570 & 14338 \\
\hline 11 Automóveis, caminhões e ônibus & 0 & 0 & 848 & 7134 & 1248 & 326 & 0 & 9207 & 17914 & 18762 \\
\hline 12 Peças e outros veículos & 0 & 0 & 12540 & 1380 & 2861 & 224 & 0 & 1229 & 5695 & 18234 \\
\hline 13 Madeira e Mobiliário & 1 & 0 & 5124 & 1328 & 1136 & 87 & 0 & 4181 & 6732 & 11856 \\
\hline 14 Celulose, Papel e Gráfica & 17 & 0 & 15798 & 49 & 2054 & 32 & 0 & 1197 & 3332 & 19129 \\
\hline 15 Indústria da Borracha & 0 & 0 & 5713 & 1 & 532 & 88 & 0 & 94 & 715 & 6428 \\
\hline 16 Elementos Químicos & 0 & 0 & 7004 & 2 & 638 & $(-) 4$ & 0 & 3401 & 4037 & 11041 \\
\hline 17 Refino de Petróleo & 14 & 0 & 34802 & (-) 57 & 1787 & 1660 & 0 & 1152 & 4542 & 39343 \\
\hline 18 Químicos Diversos & 0 & 0 & 13228 & 9 & 645 & 207 & 0 & 652 & 1513 & 14741 \\
\hline 19 Farmacêuticos e Veterinários & 0 & 0 & 4051 & 2 & 290 & 96 & 0 & 5365 & 5754 & 9805 \\
\hline 20 Artigos Plásticos & 11 & 0 & 6684 & 8 & 224 & 395 & 0 & 494 & 1121 & 7805 \\
\hline 21 Indústria Têxtil & 1 & 0 & 12578 & 5 & 1061 & 296 & 0 & 2815 & 4177 & 16755 \\
\hline 22 Artigos do Vestuário & 0 & 0 & 611 & 0 & 151 & 2 & 0 & 8144 & 8297 & 8908 \\
\hline 23 Calçados & 0 & 0 & 1279 & 0 & 1845 & 98 & 0 & 2162 & 4105 & 5384 \\
\hline 24 Indústria do Café & 13 & 0 & 2389 & 1 & 1618 & $(-) 4$ & 0 & 1384 & 3000 & 5389 \\
\hline 25 Beneficiamento de Produtos Vegetais & 9 & 0 & 8158 & 9 & 1861 & 128 & 0 & 7258 & 9256 & 17413 \\
\hline 26 Abate de Animais & 48 & 0 & 6360 & 13 & 1058 & 464 & 0 & 8562 & 10097 & 16457 \\
\hline 27 Indústria de Laticínios & 10 & 0 & 4650 & 4 & 12 & 90 & 0 & 2776 & 2882 & 7531 \\
\hline 28 Fabricação de Açúcar & 11 & 0 & 2842 & 1 & 1614 & (-) 107 & 0 & 743 & 2251 & 5092 \\
\hline 29 Fabricação de Óleos Vegetais & 6 & 0 & 6200 & 3 & 2655 & 106 & 0 & 1850 & 4614 & 10814 \\
\hline 30 Outros Produtos Alimentares & 37 & 0 & 13239 & 7 & 943 & 214 & 0 & 9427 & 10591 & 23830 \\
\hline 31 Indústrias Diversas & 37 & 0 & 4082 & 95 & 458 & 66 & 0 & 1930 & 2549 & 6632 \\
\hline 32 Serviços Industriais de Utilidade Pública & 40 & 0 & 18895 & 13 & 10 & 0 & 0 & 8854 & 8877 & 27772 \\
\hline 33 Construção Civil & 14 & 0 & 8969 & 82370 & 0 & 0 & 0 & 8 & 82379 & 91348 \\
\hline 34 Comércio & 34 & 0 & 32030 & 3391 & 1442 & 548 & 0 & 38502 & 43884 & 75914 \\
\hline 35 Supermercados & 0 & 0 & 149 & 0 & 0 & 0 & 0 & 38695 & 38695 & 38844 \\
\hline 36 Transportes & 19 & 0 & 20749 & 378 & 4582 & 200 & 0 & 14163 & 19323 & 40072 \\
\hline 37 Comunicações & 11 & 0 & 5875 & 7 & 64 & 4 & 0 & 4681 & 4756 & 10631 \\
\hline 38 Instituições Financeiras & 1 & 36245 & 49393 & 0 & 234 & 0 & 0 & 12629 & 12863 & 62256 \\
\hline 39 Serviços Prestados às Famílias & 27 & 0 & 14894 & 10 & 994 & 3 & 0 & 55306 & 56314 & 71208 \\
\hline 40 Serviços Prestados às Empresas & 23 & 0 & 24505 & 1255 & 923 & 1 & 0 & 833 & 3011 & 27516 \\
\hline 41 Aluguel de Imóveis & 79 & 0 & 7756 & 0 & 2 & 0 & 0 & 55335 & 55337 & 63093 \\
\hline 42 Administração Pública & 12 & 0 & 10865 & 418 & 715 & 20 & 126652 & 1669 & 129474 & 140339 \\
\hline 43 Serviços Privados não-mercantis & 0 & 0 & 0 & 0 & 0 & 0 & 0 & 7829 & 7829 & 7829 \\
\hline Produção nacional & 537 & 36245 & 501499 & 116617 & 48505 & 9296 & 126652 & 343418 & 644488 & 1145987 \\
\hline Importação & 17 & 234 & 39016 & 9073 & 189 & 756 & 0 & 12280 & 22298 & 61314 \\
\hline Imposto de importação & 1 & 0 & 2223 & 849 & 23 & 36 & 0 & 1745 & 2653 & 4876 \\
\hline ICM nacional & 54 & 0 & 19675 & 2945 & 672 & 770 & 0 & 21357 & 25744 & 45419 \\
\hline ICM importado & 2 & 0 & 852 & 689 & 0 & 46 & 0 & 1066 & 1801 & 2653 \\
\hline IPI nacional & 10 & 91 & 7199 & 1102 & 383 & 302 & 0 & 4585 & 6372 & 13571 \\
\hline IPI importado & 2 & 1 & 931 & 1320 & 0 & 53 & 0 & 772 & 2145 & 3076 \\
\hline Outros impostos indiretos líquidos nacional & 0 & 0 & 2090 & 0 & 140 & $(-) 1$ & 0 & 1537 & 1676 & 3767 \\
\hline Outros impostos indiretos líquidos importado & 0 & 0 & 683 & 158 & 4 & 16 & 0 & 150 & 328 & 1011 \\
\hline Consumo intermediário & 624 & 36570 & 574169 & 132753 & 49917 & 11274 & 126652 & 354274 & 674870 & 1249039 \\
\hline Remunerações & 7086 & 0 & 247277 & 0 & 0 & 0 & 0 & 0 & 0 & 247277 \\
\hline Salários & 6568 & 0 & 191410 & 0 & 0 & 0 & 0 & 0 & 0 & 191410 \\
\hline Contribuições sociais efetivas & 518 & 0 & 30176 & 0 & 0 & 0 & 0 & 0 & 0 & 30176 \\
\hline Previdência oficial/FGTS & 501 & 0 & 27077 & 0 & 0 & 0 & 0 & 0 & 0 & 27077 \\
\hline Previdência privada & 17 & 0 & 3099 & 0 & 0 & 0 & 0 & 0 & 0 & 3099 \\
\hline Contribuiçōes sociais fictícias & 0 & 0 & 25692 & 0 & 0 & 0 & 0 & 0 & 0 & 25692 \\
\hline Excedente operacional bruto (EOB) & 33 & (-) 36570 & 298374 & 0 & 0 & 0 & 0 & 0 & 0 & 298374 \\
\hline Rendimento de autônomos & 0 & 0 & 38129 & 0 & 0 & 0 & 0 & 0 & 0 & 38129 \\
\hline EOB Exclusive rendimento de autônomos & 33 & (-) 36570 & 260245 & 0 & 0 & 0 & 0 & 0 & 0 & 260245 \\
\hline Valor adicionado a custo de fatores & 7120 & (-) 36570 & 545651 & 0 & 0 & 0 & 0 & 0 & 0 & 545651 \\
\hline Outros impostos sobre a produção & 71 & 0 & 29742 & 0 & 0 & 0 & 0 & 0 & 0 & 29742 \\
\hline Outros subsídios à produção & 0 & 0 & (-) 3575 & 0 & 0 & 0 & 0 & 0 & 0 & (-) 3575 \\
\hline Valor adicionado a preço básico & 7190 & (-) 36570 & 571818 & 0 & 0 & 0 & 0 & 0 & 0 & 571818 \\
\hline Valor da produção & 7829 & 0 & 1145987 & 0 & 0 & 0 & 0 & 0 & 0 & 1145987 \\
\hline Pessoal ocupado & 5407 & 0 & 61226 & 0 & 0 & 0 & 0 & 0 & 0 & 0 \\
\hline
\end{tabular}


ANEXO F - Matriz de insumo-produto do Brasil do ano de 1999, valores nominais em milhões de $\mathrm{R} \$$ (nova proposta metodológica).

\begin{tabular}{|c|c|c|c|c|c|c|c|c|c|c|c|c|c|}
\hline Setores & 1 & 2 & 3 & 4 & 5 & 6 & 7 & 8 & 9 & 10 & 11 & 12 & 13 \\
\hline 1 Agropecuária & 18346 & 12 & 0 & 135 & 971 & 21 & 7 & 0 & 0 & 1 & 0 & 0 & 2147 \\
\hline 2 Extrativa Mineral & 300 & 668 & 9 & 668 & 854 & 672 & 69 & 0 & 27 & 20 & 1 & 1 & 0 \\
\hline 3 Petróleo e gás & 1 & 0 & 3 & 5 & 150 & 2 & 3 & 0 & 0 & 0 & 0 & 0 & 0 \\
\hline 4 Minerais não-metálicos & 96 & 97 & 75 & 3398 & 217 & 217 & 196 & 154 & 300 & 145 & 148 & 117 & 70 \\
\hline 5 Siderurgia & 7 & 5 & 46 & 293 & 12316 & 93 & 6702 & 1565 & 595 & 98 & 846 & 1162 & 70 \\
\hline 6 Metalurgia de não-ferrosos & 5 & 2 & 28 & 3 & 241 & 3755 & 1139 & 490 & 1588 & 177 & 122 & 815 & 56 \\
\hline 7 Outros Produtos Metalúrgicos & 199 & 249 & 319 & 192 & 565 & 244 & 2051 & 2222 & 878 & 310 & 610 & 2586 & 285 \\
\hline 8 Máquinas e Equipamentos & 252 & 347 & 291 & 294 & 641 & 247 & 534 & 772 & 714 & 149 & 420 & 839 & 89 \\
\hline 9 Material Elétrico & 13 & 13 & 9 & 13 & 55 & 21 & 54 & 424 & 1183 & 299 & 50 & 125 & 7 \\
\hline 10 Equipamentos Eletrônicos & 8 & 10 & 5 & 14 & 22 & 6 & 13 & 64 & 58 & 861 & 12 & 31 & 4 \\
\hline 11 Automóveis, caminhões e ônibus & 7 & 5 & 6 & 8 & 13 & 8 & 18 & 28 & 10 & 3 & 198 & 96 & 5 \\
\hline 12 Peças e outros veículos & 16 & 11 & 8 & 8 & 18 & 24 & 37 & 260 & 43 & 12 & 3633 & 2279 & 15 \\
\hline 13 Madeira e Mobiliário & 138 & 10 & 9 & 22 & 29 & 27 & 63 & 66 & 61 & 168 & 83 & 117 & 1784 \\
\hline 14 Celulose, Papel e Gráfica & 62 & 45 & 108 & 377 & 90 & 76 & 243 & 152 & 220 & 118 & 69 & 142 & 116 \\
\hline 15 Indústria da Borracha & 6 & 35 & 10 & 46 & 88 & 14 & 57 & 203 & 52 & 14 & 713 & 182 & 44 \\
\hline 16 Elementos Químicos & 229 & 20 & 2 & 234 & 166 & 499 & 89 & 36 & 57 & 12 & 24 & 31 & 27 \\
\hline 17 Refino de Petróleo & 3310 & 495 & 137 & 1174 & 468 & 148 & 396 & 277 & 490 & 82 & 135 & 362 & 422 \\
\hline 18 Químicos Diversos & 9398 & 220 & 81 & 332 & 182 & 338 & 267 & 161 & 192 & 33 & 287 & 143 & 389 \\
\hline 19 Farmacêuticos e Veterinários & 462 & 6 & 2 & 5 & 5 & 11 & 3 & 2 & 2 & 1 & 2 & 2 & 4 \\
\hline 20 Artigos Plásticos & 292 & 18 & 12 & 46 & 15 & 27 & 93 & 179 & 405 & 256 & 227 & 219 & 398 \\
\hline 21 Indústria Têxtil & 224 & 14 & 2 & 13 & 7 & 4 & 7 & 36 & 10 & 8 & 52 & 69 & 160 \\
\hline 22 Artigos do Vestuário & 3 & 4 & 3 & 2 & 6 & 1 & 3 & 4 & 2 & 2 & 11 & 3 & 3 \\
\hline 23 Calçados & 27 & 0 & 0 & 1 & 1 & 0 & 3 & 9 & 3 & 2 & 17 & 3 & 22 \\
\hline 24 Indústria do Café & 1 & 0 & 0 & 0 & 0 & 0 & 0 & 0 & 0 & 0 & 0 & 0 & 0 \\
\hline 25 Beneficiamento de Produtos Vegetais & 67 & 1 & 1 & 2 & 3 & 2 & 2 & 2 & 2 & 1 & 2 & 2 & 6 \\
\hline 26 Abate de Animais & 77 & 0 & 0 & 1 & 5 & 0 & 1 & 1 & 1 & 0 & 1 & 1 & 12 \\
\hline 27 Indústria de Laticínios & 6 & 0 & 0 & 1 & 1 & 1 & 1 & 1 & 1 & 1 & 2 & 2 & 1 \\
\hline 28 Fabricação de Açúcar & 7 & 1 & 1 & 1 & 2 & 1 & 1 & 1 & 1 & 0 & 1 & 1 & 1 \\
\hline 29 Fabricação de Óleos Vegetais & 930 & 1 & 0 & 1 & 1 & 2 & 1 & 1 & 1 & 1 & 1 & 1 & 1 \\
\hline 30 Outros Produtos Alimentares & 4252 & 8 & 2 & 10 & 6 & 3 & 9 & 11 & 5 & 3 & 4 & 6 & 12 \\
\hline 31 Indústrias Diversas & 68 & 14 & 29 & 24 & 202 & 133 & 38 & 17 & 17 & 14 & 28 & 26 & 10 \\
\hline 32 Serviços Industriais de Utilidade Pública & 654 & 369 & 384 & 830 & 1134 & 913 & 604 & 459 & 192 & 70 & 138 & 310 & 349 \\
\hline 33 Construção Civil & 5 & 30 & 94 & 43 & 34 & 24 & 53 & 69 & 28 & 22 & 29 & 44 & 27 \\
\hline 34 Comércio & 4691 & 340 & 278 & 844 & 769 & 583 & 923 & 1111 & 900 & 610 & 1478 & 1335 & 1044 \\
\hline 35 Supermercados & 0 & 0 & 0 & 0 & 0 & 0 & 0 & 0 & 0 & 0 & 0 & 0 & 0 \\
\hline 36 Transportes & 2208 & 358 & 188 & 772 & 784 & 263 & 385 & 300 & 263 & 174 & 463 & 193 & 352 \\
\hline 37 Comunicações & 65 & 94 & 114 & 253 & 219 & 119 & 276 & 498 & 254 & 217 & 194 & 204 & 193 \\
\hline 38 Instituições Financeiras & 675 & 299 & 428 & 246 & 463 & 240 & 243 & 187 & 264 & 188 & 334 & 263 & 69 \\
\hline 39 Serviços Prestados às Famílias & 110 & 33 & 40 & 50 & 46 & 18 & 38 & 81 & 36 & 27 & 38 & 32 & 40 \\
\hline 40 Serviços Prestados às Empresas & 1121 & 346 & 693 & 186 & 195 & 76 & 187 & 302 & 279 & 209 & 362 & 210 & 130 \\
\hline 41 Aluguel de Imóveis & 16 & 59 & 36 & 85 & 27 & 28 & 95 & 98 & 62 & 44 & 22 & 43 & 73 \\
\hline 42 Administração Pública & 566 & 63 & 124 & 80 & 60 & 29 & 62 & 70 & 72 & 49 & 107 & 77 & 60 \\
\hline 43 Serviços Privados não-mercantis & 0 & 0 & 0 & 0 & 0 & 0 & 0 & 0 & 0 & 0 & 0 & 0 & 0 \\
\hline Produção nacional & 48918 & 4303 & 3579 & 10710 & 21073 & 8892 & 14966 & 10314 & 9265 & 4402 & 10865 & 12074 & 8497 \\
\hline Importação & 4097 & 493 & 464 & 1001 & 2053 & 1482 & 1247 & 1284 & 1604 & 1537 & 3007 & 2505 & 448 \\
\hline Imposto de importação & 174 & 30 & 23 & 59 & 77 & 95 & 102 & 114 & 155 & 145 & 198 & 186 & 40 \\
\hline ICM nacional e importado & 1654 & 177 & 159 & 874 & 507 & 350 & 556 & 623 & 527 & 367 & 882 & 817 & 461 \\
\hline IPI nacional e importado & 226 & 70 & 84 & 208 & 159 & 130 & 315 & 296 & 306 & 172 & 338 & 362 & 125 \\
\hline Oiil nacional e importado & 197 & 72 & 100 & 64 & 138 & 65 & 63 & 48 & 69 & 50 & 94 & 72 & 17 \\
\hline Consumo intermediário & 55265 & 5144 & 4409 & 12916 & 24007 & 11012 & 17249 & 12680 & 11925 & 6673 & 15384 & 16016 & 9587 \\
\hline Remunerações & 10114 & 973 & 1269 & 2770 & 727 & 451 & 4588 & 5248 & 1545 & 1151 & 1347 & 3447 & 2731 \\
\hline Salários & 8539 & 720 & 573 & 2034 & 483 & 331 & 3521 & 3847 & 1154 & 850 & 982 & 2550 & 2137 \\
\hline Contribuições sociais efetivas & 1575 & 253 & 696 & 736 & 244 & 120 & 1067 & 1400 & 392 & 301 & 365 & 897 & 594 \\
\hline Previdência oficial/FGTS & 1570 & 186 & 210 & 690 & 163 & 111 & 1034 & 1365 & 361 & 266 & 330 & 858 & 581 \\
\hline Previdência privada & 5 & 67 & 486 & 46 & 81 & 9 & 33 & 35 & 30 & 34 & 35 & 39 & 13 \\
\hline Contribuições sociais fictícias & 0 & 0 & 0 & 0 & 0 & 0 & 0 & 0 & 0 & 0 & 0 & 0 & 0 \\
\hline Excedente operacional bruto (EOB) & 61314 & 2570 & 7406 & 4846 & 4996 & 2014 & 2491 & 10500 & 1512 & 3190 & 3215 & 2059 & 3425 \\
\hline Rendimento de autônomos & 329 & 113 & 0 & 45 & 0 & 0 & 407 & 0 & 0 & 0 & 0 & 0 & 625 \\
\hline EOB Exclusive rendimento de autônomos & 60985 & 2457 & 7406 & 4801 & 4996 & 2014 & 2084 & 10500 & 1512 & 3190 & 3215 & 2059 & 2800 \\
\hline Valor adicionado a custo de fatores & 71427 & 3543 & 8675 & 7616 & 5724 & 2465 & 7080 & 15748 & 3057 & 4341 & 4562 & 5506 & 6156 \\
\hline Outros impostos sobre a produção & 3 & 413 & 650 & 1013 & 1449 & 660 & 1133 & 1471 & 753 & 553 & 992 & 1094 & 657 \\
\hline Outros subsídios à produção & (-) 1014 & 0 & 0 & 0 & 0 & 0 & $(-) \quad 0$ & (-) 142 & (-) 52 & 0 & 0 & (-) 334 & 0 \\
\hline Valor adicionado a preço básico & 70417 & 3956 & 9325 & 8628 & 7172 & 3125 & 8213 & 17076 & 3758 & 4893 & 5554 & 6266 & 6813 \\
\hline Valor da produção & 125682 & 9100 & 13734 & 21544 & 31179 & 14138 & 25462 & 29756 & 15684 & 11566 & 20939 & 22282 & 16401 \\
\hline Pessoal ocupado & 14363 & 190 & 37 & 430 & 64 & 49 & 615 & 381 & 120 & 89 & 73 & 207 & 812 \\
\hline
\end{tabular}


ANEXO F - Matriz de insumo-produto do Brasil do ano de 1999, valores nominais em milhões de $\mathrm{R} \$$ (nova proposta metodológica).

\begin{tabular}{|c|c|c|c|c|c|c|c|c|c|c|c|c|c|c|}
\hline Setores & 14 & 15 & 16 & 17 & 18 & 19 & 20 & 21 & 22 & 23 & 24 & 25 & 26 & 27 \\
\hline 1 Agropecuária & 683 & 378 & 2743 & 0 & 163 & 35 & 0 & 1454 & 5 & 41 & 4895 & 11078 & 14500 & 3255 \\
\hline 2 Extrativa Mineral & 48 & 6 & 210 & 22 & 166 & 26 & 0 & 1 & 0 & 4 & 0 & 3 & 8 & 0 \\
\hline 3 Petróleo e gás & 0 & 0 & 1 & 13422 & 4 & 0 & 0 & 0 & 0 & 0 & 0 & 0 & 0 & 0 \\
\hline 4 Minerais não-metálicos & 48 & 5 & 128 & 68 & 103 & 239 & 21 & 3 & 1 & 4 & 20 & 143 & 5 & 7 \\
\hline 5 Siderurgia & 7 & 3 & 14 & 131 & 259 & 9 & 2 & 3 & 1 & 1 & 0 & 6 & 4 & 2 \\
\hline 6 Metalurgia de não-ferrosos & 101 & 1 & 34 & 11 & 79 & 4 & 1 & 1 & 0 & 1 & 0 & 2 & 2 & 1 \\
\hline 7 Outros Produtos Metalúrgicos & 122 & 79 & 123 & 231 & 217 & 105 & 41 & 79 & 35 & 33 & 13 & 263 & 148 & 81 \\
\hline 8 Máquinas e Equipamentos & 409 & 77 & 417 & 593 & 118 & 77 & 74 & 233 & 23 & 32 & 12 & 116 & 95 & 31 \\
\hline 9 Material Elétrico & 14 & 6 & 25 & 21 & 10 & 4 & 5 & 9 & 1 & 2 & 1 & 7 & 5 & 2 \\
\hline 10 Equipamentos Eletrônicos & 12 & 2 & 11 & 14 & 5 & 3 & 3 & 8 & 1 & 2 & 1 & 5 & 4 & 1 \\
\hline 11 Automóveis, caminhões e ônibus & 9 & 2 & 8 & 10 & 3 & 2 & 2 & 5 & 1 & 1 & 0 & 4 & 4 & 1 \\
\hline 12 Peças e outros veículos & 10 & 10 & 10 & 14 & 6 & 4 & 3 & 6 & 1 & 3 & 1 & 6 & 4 & 2 \\
\hline 13 Madeira e Mobiliário & 158 & 5 & 3 & 8 & 53 & 5 & 15 & 14 & 7 & 29 & 1 & 62 & 25 & 2 \\
\hline 14 Celulose, Papel e Gráfica & 7052 & 22 & 50 & 325 & 197 & 522 & 188 & 133 & 87 & 160 & 65 & 451 & 162 & 82 \\
\hline 15 Indústria da Borracha & 48 & 1595 & 34 & 29 & 33 & 15 & 20 & 48 & 14 & 229 & 1 & 11 & 9 & 3 \\
\hline 16 Elementos Químicos & 464 & 42 & 675 & 1172 & 1986 & 611 & 42 & 77 & 2 & 36 & 1 & 16 & 11 & 2 \\
\hline 17 Refino de Petróleo & 728 & 1157 & 680 & 15677 & 3336 & 679 & 3167 & 1469 & 81 & 231 & 60 & 265 & 136 & 73 \\
\hline 18 Químicos Diversos & 1002 & 232 & 141 & 555 & 3917 & 627 & 287 & 426 & 14 & 182 & 4 & 44 & 25 & 12 \\
\hline 19 Farmacêuticos e Veterinários & 13 & 4 & 18 & 22 & 111 & 880 & 3 & 4 & 1 & 4 & 0 & 6 & 11 & 2 \\
\hline 20 Artigos Plásticos & 98 & 15 & 21 & 64 & 216 & 264 & 542 & 127 & 60 & 253 & 20 & 134 & 213 & 142 \\
\hline 21 Indústria Têxtil & 56 & 265 & 7 & 41 & 25 & 11 & 99 & 7115 & 4036 & 108 & 21 & 83 & 12 & 3 \\
\hline 22 Artigos do Vestuário & 4 & 5 & 2 & 7 & 2 & 2 & 2 & 13 & 22 & 5 & 1 & 3 & 2 & 1 \\
\hline 23 Calçados & 4 & 9 & 1 & 1 & 12 & 2 & 4 & 8 & 60 & 791 & 0 & 1 & 24 & 1 \\
\hline 24 Indústria do Café & 1 & 0 & 0 & 1 & 0 & 1 & 0 & 0 & 0 & 0 & 1870 & 4 & 1 & 0 \\
\hline 25 Beneficiamento de Produtos Vegetais & 52 & 2 & 5 & 5 & 35 & 43 & 1 & 9 & 1 & 1 & 6 & 679 & 49 & 46 \\
\hline 26 Abate de Animais & 5 & 2 & 6 & 1 & 4 & 35 & 0 & 3 & 0 & 377 & 0 & 47 & 2082 & 0 \\
\hline 27 Indústria de Laticínios & 2 & 1 & 0 & 2 & 4 & 13 & 1 & 1 & 1 & 2 & 0 & 15 & 8 & 1439 \\
\hline 28 Fabricação de Açúcar & 2 & 0 & 491 & 2 & 16 & 19 & 0 & 1 & 0 & 0 & 0 & 122 & 1 & 35 \\
\hline 29 Fabricação de Óleos Vegetais & 3 & 1 & 159 & 43 & 339 & 1069 & 1 & 6 & 1 & 1 & 0 & 116 & 9 & 36 \\
\hline 30 Outros Produtos Alimentares & 13 & 3 & 10 & 8 & 17 & 26 & 3 & 9 & 5 & 6 & 3 & 48 & 136 & 20 \\
\hline 31 Indústrias Diversas & 230 & 16 & 38 & 49 & 49 & 17 & 19 & 22 & 16 & 12 & 10 & 13 & 12 & 10 \\
\hline 32 Serviços Industriais de Utilidade Pública & 975 & 108 & 903 & 1037 & 163 & 116 & 224 & 474 & 88 & 98 & 47 & 302 & 304 & 93 \\
\hline 33 Construção Civil & 78 & 8 & 47 & 100 & 31 & 30 & 16 & 27 & 10 & 10 & 7 & 26 & 44 & 13 \\
\hline 34 Comércio & 1840 & 446 & 375 & 1696 & 972 & 1140 & 417 & 1127 & 521 & 435 & 298 & 1903 & 1449 & 334 \\
\hline 35 Supermercados & 0 & 0 & 0 & 0 & 0 & 0 & 0 & 0 & 0 & 0 & 0 & 0 & 0 & 0 \\
\hline 36 Transportes & 462 & 107 & 322 & 2062 & 524 & 409 & 114 & 324 & 76 & 108 & 98 & 460 & 694 & 155 \\
\hline 37 Comunicações & 608 & 56 & 108 & 387 & 225 & 228 & 120 & 155 & 99 & 69 & 66 & 164 & 207 & 62 \\
\hline 38 Instituições Financeiras & 360 & 40 & 262 & 782 & 358 & 8 & 56 & 234 & 33 & 29 & 47 & 173 & 244 & 52 \\
\hline 39 Serviços Prestados às Famílias & 72 & 15 & 24 & 54 & 34 & 38 & 17 & 48 & 37 & 12 & 12 & 40 & 40 & 16 \\
\hline 40 Serviços Prestados às Empresas & 549 & 63 & 109 & 403 & 158 & 658 & 102 & 139 & 142 & 84 & 82 & 304 & 273 & 106 \\
\hline 41 Aluguel de Imóveis & 188 & 15 & 16 & 74 & 54 & 63 & 48 & 58 & 67 & 22 & 14 & 46 & 57 & 15 \\
\hline 42 Administração Pública & 961 & 18 & 27 & 115 & 160 & 207 & 40 & 45 & 34 & 34 & 21 & 187 & 67 & 27 \\
\hline 43 Serviços Privados não-mercantis & 0 & 0 & 0 & 0 & 0 & 0 & 0 & 0 & 0 & 0 & 0 & 0 & 0 & 0 \\
\hline Produção nacional & 17492 & 4819 & 8257 & 39259 & 14163 & 8244 & 5698 & 13918 & 5585 & 3450 & 7700 & 17358 & 21085 & 6167 \\
\hline Importação & 1664 & 670 & 877 & 8277 & 2692 & 1177 & 999 & 2023 & 441 & 342 & 64 & 1489 & 329 & 263 \\
\hline Imposto de importação & 109 & 70 & 59 & 536 & 179 & 76 & 104 & 178 & 51 & 31 & 3 & 39 & 15 & 9 \\
\hline ICM nacional e importado & 1015 & 360 & 296 & 802 & 369 & 417 & 167 & 468 & 454 & 259 & 131 & 462 & 403 & 689 \\
\hline IPI nacional e importado & 409 & 132 & 61 & 184 & 145 & 153 & 69 & 80 & 24 & 57 & 13 & 138 & 64 & 30 \\
\hline Oiil nacional e importado & 89 & 13 & 65 & 261 & 105 & 9 & 18 & 61 & 9 & 8 & 11 & 65 & 59 & 14 \\
\hline Consumo intermediário & 20779 & 6064 & 9615 & 49319 & 17653 & 10076 & 7055 & 16728 & 6564 & 4148 & 7922 & 19550 & 21955 & 7171 \\
\hline Remunerações & 4240 & 550 & 895 & 1598 & 2439 & 1822 & 2002 & 1542 & 1699 & 1149 & 401 & 1609 & 1344 & 462 \\
\hline Salários & 3169 & 421 & 660 & 740 & 1784 & 1355 & 1467 & 1163 & 1337 & 862 & 321 & 1185 & 1061 & 354 \\
\hline Contribuições sociais efetivas & 1071 & 129 & 234 & 859 & 656 & 467 & 535 & 379 & 362 & 287 & 80 & 424 & 282 & 108 \\
\hline Previdência oficial/FGTS & 1026 & 121 & 221 & 247 & 596 & 425 & 509 & 369 & 362 & 280 & 80 & 383 & 271 & 104 \\
\hline Previdência privada & 45 & 8 & 14 & 612 & 60 & 42 & 26 & 11 & 0 & 7 & 0 & 41 & 11 & 5 \\
\hline Contribuições sociais fictícias & 0 & 0 & 0 & 0 & 0 & 0 & 0 & 0 & 0 & 0 & 0 & 0 & 0 & 0 \\
\hline Excedente operacional bruto (EOB) & 3308 & 1524 & 5821 & 20830 & 4216 & 5308 & 982 & 2001 & 1884 & 1051 & 1950 & 4478 & 2019 & 1223 \\
\hline Rendimento de autônomos & 165 & 0 & 0 & 0 & 0 & 0 & 0 & 4 & 1585 & 31 & 16 & 56 & 46 & 0 \\
\hline EOB Exclusive rendimento de autônomos & 3143 & 1524 & 5821 & 20830 & 4216 & 5308 & 982 & 1997 & 299 & 1020 & 1934 & 4422 & 1974 & 1223 \\
\hline Valor adicionado a custo de fatores & 7548 & 2074 & 6716 & 22428 & 6655 & 7131 & 2984 & 3543 & 3583 & 2200 & 2351 & 6087 & 3363 & 1686 \\
\hline Outros impostos sobre a produção & 1386 & 404 & 808 & 3483 & 1225 & 858 & 527 & 1000 & 328 & 304 & 485 & 1212 & 1197 & 428 \\
\hline Outros subsídios à produção & 0 & 0 & 0 & 0 & 0 & 0 & 0 & 0 & 0 & 0 & 0 & 0 & 0 & 0 \\
\hline Valor adicionado a preço básico & 8934 & 2478 & 7524 & 25911 & 7880 & 7989 & 3511 & 4543 & 3911 & 2504 & 2836 & 7299 & 4560 & 2113 \\
\hline Valor da produção & 29713 & 8542 & 17139 & 75230 & 25533 & 18065 & 10566 & 21271 & 10475 & 6652 & 10758 & 26849 & 26515 & 9284 \\
\hline Pessoal ocupado & 417 & 47 & 57 & 45 & 152 & 119 & 206 & 238 & 1451 & 334 & 71 & 321 & 232 & 57 \\
\hline
\end{tabular}


ANEXO F - Matriz de insumo-produto do Brasil do ano de 1999, valores nominais em milhões de $\mathrm{R}$ \$ (nova proposta metodológica).

\begin{tabular}{|c|c|c|c|c|c|c|c|c|c|}
\hline Setores & 28 & 29 & 30 & 31 & 32 & 33 & 34 & 35 & 36 \\
\hline 1 Agropecuária & 2004 & 5659 & 4229 & 32 & 18 & 9 & 0 & 5274 & 0 \\
\hline 2 Extrativa Mineral & 0 & 3 & 120 & 272 & 7 & 401 & 4 & 10 & 1 \\
\hline 3 Petróleo e gás & 0 & 0 & 0 & 1 & 11 & 2 & 1 & 0 & 1 \\
\hline 4 Minerais não-metálicos & 26 & 7 & 405 & 144 & 5 & 12033 & 5 & 215 & 1 \\
\hline 5 Siderurgia & 2 & 6 & 10 & 59 & 1 & 1293 & 6 & 7 & 7 \\
\hline 6 Metalurgia de não-ferrosos & 1 & 3 & 4 & 235 & 1 & 981 & 2 & 94 & 3 \\
\hline 7 Outros Produtos Metalúrgicos & 73 & 298 & 399 & 163 & 52 & 7015 & 102 & 385 & 183 \\
\hline 8 Máquinas e Equipamentos & 324 & 67 & 197 & 76 & 1046 & 1055 & 275 & 119 & 173 \\
\hline 9 Material Elétrico & 10 & 4 & 10 & 41 & 335 & 2471 & 33 & 874 & 17 \\
\hline 10 Equipamentos Eletrônicos & 8 & 3 & 8 & 7 & 12 & 44 & 8 & 838 & 10 \\
\hline 11 Automóveis, caminhões e ônibus & 3 & 3 & 8 & 2 & 91 & 52 & 14 & 4 & 35 \\
\hline 12 Peças e outros veículos & 7 & 4 & 9 & 5 & 20 & 140 & 9 & 14 & 2181 \\
\hline 13 Madeira e Mobiliário & 6 & 8 & 65 & 90 & 5 & 2591 & 109 & 52 & 44 \\
\hline 14 Celulose, Papel e Gráfica & 97 & 125 & 883 & 252 & 127 & 100 & 1770 & 2207 & 211 \\
\hline 15 Indústria da Borracha & 21 & 6 & 17 & 38 & 26 & 236 & 1 & 1 & 1475 \\
\hline 16 Elementos Químicos & 63 & 35 & 187 & 55 & 20 & 129 & 6195 & 21 & 71 \\
\hline 17 Refino de Petróleo & 127 & 172 & 501 & 413 & 765 & 1499 & 19857 & 45 & 10030 \\
\hline 18 Químicos Diversos & 51 & 73 & 388 & 171 & 40 & 1995 & 14 & 196 & 61 \\
\hline 19 Farmacêuticos e Veterinários & 2 & 5 & 134 & 3 & 10 & 6 & 8 & 3621 & 4 \\
\hline 20 Artigos Plásticos & 22 & 50 & 296 & 199 & 12 & 2115 & 601 & 244 & 788 \\
\hline 21 Indústria Têxtil & 248 & 234 & 39 & 144 & 13 & 36 & 105 & 243 & 297 \\
\hline 22 Artigos do Vestuário & 5 & 1 & 3 & 2 & 0 & 11 & 5 & 661 & 7 \\
\hline 23 Calçados & 0 & 2 & 8 & 18 & 0 & 14 & 5 & 206 & 13 \\
\hline 24 Indústria do Café & 0 & 1 & 8 & 0 & 0 & 1 & 2 & 1018 & 1 \\
\hline 25 Beneficiamento de Produtos Vegetais & 1 & 244 & 4300 & 1 & 1 & 7 & 6 & 5772 & 5 \\
\hline 26 Abate de Animais & 0 & 102 & 222 & 7 & 1 & 2 & 5 & 3948 & 3 \\
\hline 27 Indústria de Laticínios & 0 & 2 & 154 & 1 & 1 & 4 & 4 & 3765 & 2 \\
\hline 28 Fabricação de Açúcar & 1219 & 1 & 752 & 0 & 17 & 2 & 33 & 682 & 1 \\
\hline 29 Fabricação de Óleos Vegetais & 1 & 3169 & 2213 & 1 & 1 & 4 & 4 & 1623 & 2 \\
\hline 30 Outros Produtos Alimentares & 3 & 15 & 1547 & 11 & 1 & 4 & 90 & 8284 & 293 \\
\hline 31 Indústrias Diversas & 10 & 9 & 27 & 122 & 168 & 406 & 46 & 604 & 58 \\
\hline 32 Serviços Industriais de Utilidade Pública & 240 & 172 & 649 & 99 & 14543 & 212 & 1839 & 216 & 320 \\
\hline 33 Construção Civil & 47 & 14 & 45 & 15 & 222 & 5191 & 179 & 119 & 322 \\
\hline 34 Comércio & 398 & 939 & 2491 & 461 & 426 & 4172 & 2028 & 347 & 2740 \\
\hline 35 Supermercados & 0 & 0 & 0 & 0 & 0 & 0 & 0 & 0 & 0 \\
\hline 36 Transportes & 225 & 464 & 738 & 150 & 104 & 1553 & 4293 & 1148 & 6299 \\
\hline 37 Comunicações & 61 & 94 & 318 & 146 & 129 & 461 & 3014 & 385 & 1198 \\
\hline 38 Instituições Financeiras & 68 & 210 & 290 & 138 & 829 & 504 & 2089 & 403 & 1301 \\
\hline 39 Serviços Prestados às Famílias & 32 & 18 & 57 & 20 & 455 & 157 & 965 & 73 & 284 \\
\hline 40 Serviços Prestados às Empresas & 136 & 114 & 605 & 947 & 600 & 1736 & 5923 & 846 & 1484 \\
\hline 41 Aluguel de Imóveis & 13 & 22 & 191 & 53 & 378 & 159 & 3276 & 498 & 358 \\
\hline 42 Administração Pública & 34 & 41 & 236 & 184 & 118 & 303 & 1164 & 608 & 292 \\
\hline 43 Serviços Privados não-mercantis & 0 & 0 & 0 & 0 & 0 & 0 & 0 & 0 & 0 \\
\hline Produção nacional & 5590 & 12397 & 22764 & 4778 & 20613 & 49106 & 54091 & 45669 & 30580 \\
\hline Importação & 317 & 499 & 1119 & 716 & 1384 & 4209 & 2323 & 4610 & 4180 \\
\hline Imposto de importação & 27 & 16 & 58 & 40 & 61 & 416 & 33 & 364 & 187 \\
\hline ICM nacional e importado & 239 & 455 & 1078 & 209 & 2010 & 3960 & 2096 & 1980 & 1737 \\
\hline IPI nacional e importado & 41 & 67 & 370 & 111 & 136 & 1560 & 439 & 1673 & 414 \\
\hline Oiil nacional e importado & 17 & 55 & 84 & 34 & 125 & 139 & 474 & 167 & 209 \\
\hline Consumo intermediário & 6231 & 13488 & 25472 & 5888 & 24329 & 59392 & 59457 & 54464 & 37307 \\
\hline Remunerações & 696 & 300 & 3505 & 1187 & 9972 & 9791 & 28328 & 1728 & 12775 \\
\hline Salários & 538 & 232 & 2660 & 886 & 7027 & 7754 & 22074 & 1346 & 9682 \\
\hline Contribuições sociais efetivas & 158 & 68 & 845 & 302 & 2945 & 2037 & 6254 & 381 & 3093 \\
\hline Previdência oficial/FGTS & 158 & 68 & 800 & 287 & 2175 & 1984 & 6086 & 371 & 2817 \\
\hline Previdência privada & 0 & 0 & 46 & 14 & 770 & 54 & 168 & 10 & 276 \\
\hline Contribuições sociais fictícias & 0 & 0 & 0 & 0 & 0 & 0 & 0 & 0 & 0 \\
\hline Excedente operacional bruto (EOB) & 636 & 2686 & 5238 & 2044 & 16349 & 66836 & 25619 & 1265 & 9184 \\
\hline Rendimento de autônomos & 0 & 0 & 113 & 113 & 0 & 4677 & 16281 & 484 & 5587 \\
\hline EOB Exclusive rendimento de autônomos & 636 & 2686 & 5125 & 1931 & 16349 & 62159 & 9338 & 781 & 3597 \\
\hline Valor adicionado a custo de fatores & 1331 & 2986 & 8743 & 3231 & 26321 & 76627 & 53947 & 2993 & 21960 \\
\hline Outros impostos sobre a produção & 379 & 786 & 1627 & 441 & 2639 & 4789 & 4799 & 309 & 2281 \\
\hline Outros subsídios à produção & 0 & 0 & 0 & 0 & (-) 72 & $(-) \quad 317$ & $(-) 643$ & 0 & (-) 851 \\
\hline Valor adicionado a preço básico & 1711 & 3772 & 10370 & 3672 & 28888 & 81100 & 58103 & 3302 & 23390 \\
\hline Valor da produção & 7941 & 17260 & 35841 & 9560 & 53217 & 140492 & 117559 & 57766 & 60697 \\
\hline Pessoal ocupado & 75 & 35 & 665 & 278 & 216 & 3909 & 8654 & 670 & 2384 \\
\hline
\end{tabular}


ANEXO F - Matriz de insumo-produto do Brasil do ano de 1999, valores nominais em milhões de R \$ (nova proposta metodológica).

\begin{tabular}{|c|c|c|c|c|c|c|c|c|c|}
\hline Setores & 37 & 38 & 39 & 40 & 41 & 42 & 43 & 44 & $\begin{array}{c}\text { Total } \\
\text { da atividade }\end{array}$ \\
\hline 1 Agropecuária & 0 & 0 & 2569 & 0 & 0 & 1927 & 56 & 0 & 82647 \\
\hline 2 Extrativa Mineral & 1 & 9 & 3 & 13 & 1 & 16 & 1 & 0 & 4646 \\
\hline 3 Petróleo e gás & 0 & 0 & 0 & 0 & 0 & 0 & 0 & 0 & 13609 \\
\hline 4 Minerais não-metálicos & 39 & 2 & 446 & 1 & 0 & 291 & 11 & 0 & 19655 \\
\hline 5 Siderurgia & 4 & 2 & 63 & 1 & 0 & 7 & 0 & 0 & 25709 \\
\hline 6 Metalurgia de não-ferrosos & 18 & 1 & 80 & 0 & 0 & 3 & 0 & 0 & 10082 \\
\hline 7 Outros Produtos Metalúrgicos & 236 & 16 & 370 & 47 & 4 & 56 & 8 & 0 & 21684 \\
\hline 8 Máquinas e Equipamentos & 229 & 47 & 225 & 191 & 80 & 317 & 6 & 0 & 12325 \\
\hline 9 Material Elétrico & 354 & 3 & 183 & 32 & 19 & 149 & 2 & 0 & 6915 \\
\hline 10 Equipamentos Eletrônicos & 405 & 2 & 128 & 32 & 1 & 62 & 0 & 0 & 2749 \\
\hline 11 Automóveis, caminhões e ônibus & 5 & 5 & 153 & 4 & 2 & 75 & 1 & 0 & 912 \\
\hline 12 Peças e outros veículos & 79 & 3 & 2770 & 4 & 2 & 469 & 0 & 0 & 12161 \\
\hline 13 Madeira e Mobiliário & 3 & 13 & 212 & 20 & 1 & 127 & 2 & 0 & 6314 \\
\hline 14 Celulose, Papel e Gráfica & 239 & 437 & 444 & 3670 & 18 & 2793 & 22 & 0 & 24707 \\
\hline 15 Indústria da Borracha & 18 & 0 & 1848 & 0 & 0 & 70 & 0 & 0 & 7309 \\
\hline 16 Elementos Químicos & 149 & 1 & 285 & 1 & 0 & 395 & 0 & 0 & 14170 \\
\hline 17 Refino de Petróleo & 9 & 33 & 358 & 229 & 4 & 454 & 22 & 0 & 70151 \\
\hline 18 Químicos Diversos & 1 & 1 & 481 & 2 & 0 & 381 & 0 & 0 & 23347 \\
\hline 19 Farmacêuticos e Veterinários & 1 & 3 & 824 & 2 & 0 & 892 & 0 & 0 & 7101 \\
\hline 20 Artigos Plásticos & 162 & 5 & 431 & 22 & 60 & 320 & 16 & 0 & 9701 \\
\hline 21 Indústria Têxtil & 2 & 15 & 1521 & 22 & 1 & 297 & 1 & 0 & 15705 \\
\hline 22 Artigos do Vestuário & 20 & 1 & 16 & 1 & 0 & 54 & 0 & 0 & 904 \\
\hline 23 Calçados & 27 & 0 & 69 & 0 & 0 & 11 & 1 & 0 & 1378 \\
\hline 24 Indústria do Café & 0 & 1 & 433 & 0 & 0 & 52 & 12 & 0 & 3413 \\
\hline 25 Beneficiamento de Produtos Vegetais & 1 & 2 & 726 & 1 & 0 & 305 & 13 & 0 & 12414 \\
\hline 26 Abate de Animais & 1 & 2 & 1489 & 1 & 0 & 432 & 59 & 0 & 8940 \\
\hline 27 Indústria de Laticínios & 1 & 1 & 396 & 1 & 0 & 461 & 12 & 0 & 6311 \\
\hline 28 Fabricação de Açúcar & 1 & 2 & 659 & 1 & 0 & 29 & 15 & 0 & 4124 \\
\hline 29 Fabricação de Óleos Vegetais & 1 & 1 & 418 & 1 & 0 & 9 & 11 & 0 & 10186 \\
\hline 30 Outros Produtos Alimentares & 3 & 3 & 5175 & 2 & 0 & 207 & 50 & 0 & 20329 \\
\hline 31 Indústrias Diversas & 38 & 481 & 143 & 807 & 32 & 870 & 47 & 0 & 5002 \\
\hline 32 Serviços Industriais de Utilidade Pública & 208 & 400 & 1911 & 481 & 271 & 3248 & 78 & 0 & 36227 \\
\hline 33 Construção Civil & 257 & 0 & 377 & 141 & 4200 & 1193 & 19 & 0 & 13289 \\
\hline 34 Comércio & 403 & 946 & 3648 & 1055 & 42 & 5648 & 69 & 0 & 53669 \\
\hline 35 Supermercados & 0 & 0 & 368 & 0 & 0 & 0 & 0 & 0 & 368 \\
\hline 36 Transportes & 153 & 1086 & 854 & 549 & 8 & 1988 & 24 & 0 & 32256 \\
\hline 37 Comunicações & 327 & 1460 & 1122 & 1611 & 87 & 1462 & 34 & 0 & 17162 \\
\hline 38 Instituições Financeiras & 535 & 6319 & 564 & 479 & 216 & 1219 & 1 & 41218 & 62963 \\
\hline 39 Serviços Prestados às Famílias & 622 & 3441 & 1020 & 207 & 6 & 9265 & 14 & 0 & 17683 \\
\hline 40 Serviços Prestados às Empresas & 607 & 6269 & 1471 & 2586 & 86 & 11621 & 45 & 0 & 42543 \\
\hline 41 Aluguel de Imóveis & 408 & 1340 & 308 & 424 & 44 & 1145 & 85 & 0 & 10128 \\
\hline 42 Administração Pública & 129 & 1062 & 388 & 880 & 17 & 2274 & 12 & 0 & 11101 \\
\hline 43 Serviços Privados não-mercantis & 0 & 0 & 0 & 0 & 0 & 0 & 0 & 0 & 0 \\
\hline Produção nacional & 5697 & 23415 & 34949 & 13522 & 5203 & 50594 & 750 & 41218 & 761989 \\
\hline Importação & 1137 & 2011 & 4072 & 1490 & 106 & 5761 & 50 & 0 & 76511 \\
\hline Imposto de importação & 90 & 26 & 285 & 69 & 7 & 155 & 3 & 0 & 4695 \\
\hline ICM nacional e importado & 320 & 553 & 3237 & 917 & 73 & 1962 & 60 & 0 & 35130 \\
\hline IPI nacional e importado & 161 & 461 & 1240 & 337 & 37 & 1049 & 13 & 0 & 12461 \\
\hline Oiil nacional e importado & 132 & 485 & 157 & 112 & 50 & 429 & 1 & 0 & 4505 \\
\hline Consumo intermediário & 7537 & 26951 & 43940 & 16447 & 5475 & 59950 & 878 & 41218 & 895290 \\
\hline Remunerações & 8723 & 31628 & 31648 & 17603 & 2187 & 139134 & 10601 & 0 & 367922 \\
\hline Salários & 6595 & 25655 & 24099 & 13239 & 1833 & 86401 & 8994 & 0 & 262615 \\
\hline Contribuições sociais efetivas & 2128 & 5973 & 7549 & 4364 & 353 & 6140 & 1608 & 0 & 58714 \\
\hline Previdência oficial/FGTS & 1841 & 4844 & 7356 & 4235 & 353 & 6038 & 1550 & 0 & 53683 \\
\hline Previdência privada & 287 & 1129 & 193 & 129 & 0 & 103 & 58 & 0 & 5031 \\
\hline Contribuições sociais fictícias & 0 & 0 & 0 & 0 & 0 & 46593 & 0 & 0 & 46593 \\
\hline Excedente operacional bruto (EOB) & 17361 & 18975 & 16834 & 14193 & 119055 & 0 & 0 & (-) 41218 & 441189 \\
\hline Rendimento de autônomos & 0 & 2400 & 13285 & 4029 & 462 & 0 & 0 & 0 & 50852 \\
\hline EOB Exclusive rendimento de autônomos & 17361 & 16575 & 3549 & 10164 & 118592 & 0 & 0 & (-) 41218 & 390337 \\
\hline Valor adicionado a custo de fatores & 26084 & 50603 & 48482 & 31796 & 121241 & 139134 & 10601 & (-) 41218 & 809111 \\
\hline Outros impostos sobre a produção & 1789 & 3968 & 1942 & 1725 & 1271 & 1283 & 102 & 0 & 54616 \\
\hline Outros subsídios à produção & $(-) 44$ & 0 & $(-) 0$ & 0 & 0 & 0 & 0 & 0 & (-) 3469 \\
\hline Valor adicionado a preço básico & 27828 & 54571 & 50424 & 33521 & 122513 & 140417 & 10703 & (-) 41218 & 860258 \\
\hline Valor da produção & 35365 & 81522 & 94364 & 49968 & 127987 & 200367 & 11581 & 0 & 1755548 \\
\hline Pessoal ocupado & 209 & 702 & 9466 & 2454 & 278 & 5654 & 5593 & 0 & 62419 \\
\hline
\end{tabular}


ANEXO F - Matriz de insumo-produto do Brasil do ano de 1999, valores nominais em milhões de $\mathrm{R}$ \$ (nova proposta metodológica).

\begin{tabular}{|c|c|c|c|c|c|c|c|}
\hline Setores & $\begin{array}{l}\text { Formação bruta } \\
\text { de capital fixo }\end{array}$ & $\begin{array}{c}\text { Exportação } \\
\text { de bens e serviços }\end{array}$ & $\begin{array}{l}\text { Variação } \\
\text { de estoque }\end{array}$ & $\begin{array}{l}\text { Consumo do } \\
\text { Governo }\end{array}$ & $\begin{array}{l}\text { Consumo } \\
\text { das famílias }\end{array}$ & $\begin{array}{c}\text { Demanda } \\
\text { final }\end{array}$ & $\begin{array}{c}\text { Demanda } \\
\text { total }\end{array}$ \\
\hline 1 Agropecuária & 2929 & 4386 & 7905 & 0 & 27814 & 43035 & 125682 \\
\hline 2 Extrativa Mineral & 11 & 4679 & $(-) 311$ & 0 & 74 & 4453 & 9100 \\
\hline 3 Petróleo e gás & 0 & 4 & 113 & 0 & 8 & 126 & 13734 \\
\hline 4 Minerais não-metálicos & 4 & 1074 & $(-) 160$ & 0 & 971 & 1889 & 21544 \\
\hline 5 Siderurgia & 8 & 5084 & 303 & 0 & 76 & 5471 & 31179 \\
\hline 6 Metalurgia de não-ferrosos & 5 & 3142 & 554 & 0 & 355 & 4056 & 14138 \\
\hline 7 Outros Produtos Metalúrgicos & 845 & 1315 & $(-) 205$ & 0 & 1824 & 3778 & 25462 \\
\hline 8 Máquinas e Equipamentos & 13198 & 2926 & 125 & 0 & 1181 & 17431 & 29756 \\
\hline 9 Material Elétrico & 2537 & 1959 & 255 & 0 & 4018 & 8769 & 15684 \\
\hline 10 Equipamentos Eletrônicos & 3416 & 1987 & $(-) 75$ & 0 & 3489 & 8817 & 11566 \\
\hline 11 Automóveis, caminhões e ônibus & 4509 & 3190 & 286 & 0 & 12041 & 20027 & 20939 \\
\hline 12 Peças e outros veículos & 1000 & 7018 & 156 & 0 & 1948 & 10121 & 22282 \\
\hline 13 Madeira e Mobiliário & 1548 & 2407 & (-) 46 & 0 & 6177 & 10087 & 16401 \\
\hline 14 Celulose, Papel e Gráfica & 47 & 3012 & $(-) 90$ & 0 & 2037 & 5006 & 29713 \\
\hline 15 Indústria da Borracha & 1 & 922 & 113 & 0 & 196 & 1232 & 8542 \\
\hline 16 Elementos Químicos & 3 & 1585 & (-) 1102 & 0 & 2484 & 2970 & 17139 \\
\hline 17 Refino de Petróleo & $(-) 25$ & 2563 & $(-) \quad 132$ & 0 & 2673 & 5079 & 75230 \\
\hline 18 Químicos Diversos & 11 & 1170 & 54 & 0 & 951 & 2186 & 25533 \\
\hline 19 Farmacêuticos e Veterinários & 3 & 615 & 158 & 0 & 10189 & 10965 & 18065 \\
\hline 20 Artigos Plásticos & 17 & 350 & $(-) \quad 197$ & 0 & 695 & 865 & 10566 \\
\hline 21 Indústria Têxtil & 22 & 1437 & 55 & 0 & 4052 & 5566 & 21271 \\
\hline 22 Artigos do Vestuário & 0 & 108 & 4 & 0 & 9460 & 9571 & 10475 \\
\hline 23 Calçados & 0 & 2931 & (-) 99 & 0 & 2442 & 5274 & 6652 \\
\hline 24 Indústria do Café & 1 & 3403 & 1880 & 0 & 2060 & 7344 & 10758 \\
\hline 25 Beneficiamento de Produtos Vegetais & 11 & 3324 & 218 & 0 & 10882 & 14435 & 26849 \\
\hline 26 Abate de Animais & 17 & 2480 & 52 & 0 & 15026 & 17575 & 26515 \\
\hline 27 Indústria de Laticínios & 4 & 30 & $(-) 5$ & 0 & 2944 & 2973 & 9284 \\
\hline 28 Fabricação de Açúcar & 1 & 2747 & $(-) 123$ & 0 & 1192 & 3817 & 7941 \\
\hline 29 Fabricação de Óleos Vegetais & 4 & 3713 & 36 & 0 & 3322 & 7074 & 17260 \\
\hline 30 Outros Produtos Alimentares & 9 & 1951 & $(-) 104$ & 0 & 13655 & 15512 & 35841 \\
\hline 31 Indústrias Diversas & 778 & 944 & $(-) 83$ & 0 & 2920 & 4559 & 9560 \\
\hline 32 Serviços Industriais de Utilidade Pública & 4 & 13 & 0 & 0 & 16973 & 16990 & 53217 \\
\hline 33 Construção Civil & 127164 & 32 & 0 & 0 & 7 & 127203 & 140492 \\
\hline 34 Comércio & 4194 & 7946 & 786 & 0 & 50964 & 63890 & 117559 \\
\hline 35 Supermercados & 0 & 0 & 0 & 0 & 57398 & 57398 & 57766 \\
\hline 36 Transportes & 413 & 3922 & 135 & 0 & 23971 & 28441 & 60697 \\
\hline 37 Comunicações & 48 & 111 & (-) 5 & 0 & 18050 & 18204 & 35365 \\
\hline 38 Instituições Financeiras & 0 & 462 & 0 & 0 & 18097 & 18559 & 81522 \\
\hline 39 Serviços Prestados às Famílias & 12 & 2940 & 1 & 0 & 73728 & 76681 & 94364 \\
\hline 40 Serviços Prestados às Empresas & 1431 & 4721 & 2 & 0 & 1271 & 7425 & 49968 \\
\hline 41 Aluguel de Imóveis & 0 & 0 & 0 & 0 & 117859 & 117859 & 127987 \\
\hline 42 Administração Pública & 305 & 1263 & 0 & 185858 & 1839 & 189266 & 200367 \\
\hline 43 Serviços Privados não-mercantis & 0 & 0 & 0 & 0 & 11581 & 11581 & 11581 \\
\hline Produção nacional & 164486 & 93868 & 10453 & 185858 & 538894 & 993560 & 1755548 \\
\hline Importação & 13427 & 0 & 662 & 0 & 24357 & 38446 & 114957 \\
\hline Imposto de importação & 1379 & 0 & 37 & 0 & 1695 & 3111 & 7806 \\
\hline ICM nacional e importado & 2716 & 4435 & 112 & 0 & 24644 & 31908 & 67038 \\
\hline IPI nacional e importado & 2012 & 1637 & 42 & 0 & 5810 & 9501 & 21963 \\
\hline Oiil nacional e importado & 66 & 207 & 8 & 0 & 2018 & 2299 & 6804 \\
\hline Consumo intermediário & 184087 & 100148 & 11314 & 185858 & 597418 & 1078825 & 1974115 \\
\hline Remunerações & 0 & 0 & 0 & 0 & 0 & 0 & 367922 \\
\hline Salários & 0 & 0 & 0 & 0 & 0 & 0 & 262615 \\
\hline Contribuições sociais efetivas & 0 & 0 & 0 & 0 & 0 & 0 & 58714 \\
\hline Previdência oficial/FGTS & 0 & 0 & 0 & 0 & 0 & 0 & 53683 \\
\hline Previdência privada & 0 & 0 & 0 & 0 & 0 & 0 & 5031 \\
\hline Contribuições sociais fictícias & 0 & 0 & 0 & 0 & 0 & 0 & 46593 \\
\hline Excedente operacional bruto (EOB) & 0 & 0 & 0 & 0 & 0 & 0 & 441189 \\
\hline Rendimento de autônomos & 0 & 0 & 0 & 0 & 0 & 0 & 50852 \\
\hline EOB Exclusive rendimento de autônomos & 0 & 0 & 0 & 0 & 0 & 0 & 390337 \\
\hline Valor adicionado a custo de fatores & 0 & 0 & 0 & 0 & 0 & 0 & 809111 \\
\hline Outros impostos sobre a produção & 0 & 0 & 0 & 0 & 0 & 0 & 54616 \\
\hline Outros subsídios à produção & 0 & 0 & 0 & 0 & 0 & 0 & (-) 3469 \\
\hline Valor adicionado a preço básico & 0 & 0 & 0 & 0 & 0 & 0 & 860258 \\
\hline Valor da produção & 0 & 0 & 0 & 0 & 0 & 0 & 1755548 \\
\hline Pessoal ocupado & 0 & 0 & 0 & 0 & 0 & 0 & 62419 \\
\hline
\end{tabular}




\section{REFERÊNCIAS BIBLIOGRÁFICAS}

ASSOCIAÇÃO BRASILEIRA DE SUPERMERCADOS (ABRAS). 40 Anos de Supermercados no Brasil. São Paulo, 1993. 186p.

AUTOMAÇÃO de retaguarda define o sucesso da loja. Supermercado Moderno, v.27, n.1, p.32-38, jan. 1996.

BAER, W. A economia brasileira. 4.ed. São Paulo: Nobel, 1996. 416p.

BARBOSA, M. Supermercados se unem para concorrer com gigantes. Jornal da Tarde. Caderno Economia, São Paulo, 04 ago. 1999b. p.A-9.

BARBOSA, M. Varejo leva a melhor na queda-de-braço com a indústria. Jornal da Tarde. Caderno Economia, São Paulo, 28 mar. 1999a. p.A-7.

BERTASSO, B.F. O consumo alimentar em regiões metropolitanas brasileiras: análise da pesquisa de orçamentos familiares/IBGE - 1995/96. Piracicaba, 2000. 109p. Dissertação (Mestrado) - Escola Superior de Agricultura "Luiz de Queiroz", Universidade de São Paulo.

BRITO, D. Qual é o formato correto de sua loja. SuperHiper, v.24, n.277, p.74-77, set. 1998.

CELLA, G. The input-output measurement of interindustry linkages. Oxford Bulletin of Economics and Statistics, v.70, p.705-712, 1984.

CLEMENTS, B.J. On the decomposition and normalization of interindustry linkages. Economic Letters, v.33, p.337-340, 1990. 
CONNOR, J.M.; SCHIEK, W.A. Food processing: an industrial powerhouse in transition. 2.ed. New York: John Wiley \& Sons, 1997. 665p.

CRÓCOMO, F.C. Análise das relações inter-regionais e intersetoriais na economia brasileira em 1985: uma aplicação de insumo-produto. Piracicaba, 1998. 171p. Tese (Doutorado) - Escola Superior de Agricultura "Luiz de Queiroz", Universidade de São Paulo.

CYRILLO, D.C. O papel dos supermercados no varejo de alimentos. São Paulo: Instituto de Pesquisas Econômicas, 1987. 198p.

DEMARCHI, C.; TUSZEL, L. O poder concentrado das gôndolas. Gazeta Mercantil. Caderno Negócios, São Paulo, 06 nov. 2000. p.06

DIB, J.A. Efficient consumer response (ECR): uma estratégia para o varejo de bens de consumo de massa. Revista de Administração, v.23, n.2, p.14-22, abr./jun. 1997.

FERNANDES JUNIOR, W.B.; NEVES, M.F. Estudo de caso: Companhia Real de Distribuição. In: SEMINÁRIO INTERNACIONAL DE AGRIBUSINESS DO PENSA/FIA/FEA, 6., São Paulo, 1997. v.5.

FURTUOSO, M.C.O.; BARROS, G.S.C.; GUILHOTO, J.J.M. O Produto Interno Bruto do complexo agroindustrial brasileiro. Revista de Economia e Sociologia Rural, v.36, n.3, p.9-31, jul./set. 1998.

GRAHAM, C.F.; NAZEM, S.M. From electronic data interchange to efficient consumer response: new directions for the food industry. Journal of Food Products Marketing, v.3, n.2, p.39-47, 1996.

GRINBAUM, R.; FERNANDES, F. Cresce concentração nos supermercados. Folha de São Paulo. Caderno Negócios, São Paulo, 13 abr. 1998. p.1. 
GUILHOTO, J.J.M. Leontief e insumo-produto: antecedentes, princípios e evolução. Piracicaba: ESALQ, Depto. Economia, Administração e Sociologia, 2000. 22p. (Série Seminários da Pós-Graduação, 15)

GUILHOTO, J.J.M.; FURTUOSO, M.C.O.; BARROS, G.S.C. O agronegócio na economia brasileira (1994-1999). Piracicaba: ESALQ, Centro de Estudos Avançados em Economia Aplicada, set. 2000. 112p. (Texto para discussão apresentado à Confederação Nacional da Agricultura-CNA)

GUILHOTO, J.J.M.; SESSO FILHO, U.A.; LOPES, R.L.; HILGEMBERG, C.M.A.T.; HILGEMBER, E.M. Nota metodológica: construção da matriz de insumo-produto utilizando dados preliminares das Contas Nacionais (compact disc). In: ENCONTRO BRASILEIRO DE ESTUDOS REGIONAIS E URBANOS, 2., São Paulo, 2002. Anais. São Paulo: Universidade de São Paulo, Faculdade de Economia, Administração e Contabilidade, 1999.

GUILHOTO, J.J.M.; SONIS, M.; HEWINGS, G.J.D. Linkages and multipliers in a multiregional famework: integration of alternative approaches. Urbana: University of Illinois, Regional Economics Applications Laboratory, 1996. 20p. (Discussion Paper, 96-T-8)

GUILHOTO, J.J.M.; SONIS, M.; HEWINGS, G.J.D.; MARTINS, E.B. Índices de ligações e setores-chave na economia brasileira: 1959/80. Pesquisa e Planejamento Econômico, v.24, n.2, p.287-314, ago. 1994.

HEIJBROEK, A.M.A.; VAN NOORT, W.M.H.; VAN POTTEN, A.J. The retail food market: structures. trends and strategies. Amsterdan: Rabobank, 1994. 66p.

HIRSCHMAN, A.O. The strategy of economic development. New Haven: Yale University Press, 1958. 217p. 
HOFFMANN, R. Elasticidades-renda das despesas e do consumo físico de alimentos no Brasil metropolitano em 1995-96. Agricultura em São Paulo, v.47, n.1, p.111$122,2000$.

InSTITUto BRASILEIRO DE GEOGRAFIA E estatíStiCA. Pesquisa Anual do Comércio 1999. Rio de Janeiro, 2000. v.11.

InSTITUtO BRASILEIRO DE GeOgRAFIA E estatístiCA. Pesquisa Anual do Comércio 1997. Rio de Janeiro, 1998. v.9.

InStituto BRAsileiro De GeOgRafia e estatístiCA. Pesquisa Anual do Comércio 1995. Rio de Janeiro, 1996. v.7.

InSTITUTO BRASILEIRO DE GEOGRAFIA E ESTATÍSTICA. Pesquisa Anual do Comércio 1990. Rio de Janeiro, 1992. v.1.

INSTITUTO BRASILEIRO DE GEOGRAFIA E ESTATÍSTICA. Sistemas de Contas Nacionais: Brasil, 1998-2000. Rio de Janeiro, 2002. 201p.

INSTITUTO BRASILEIRO DE GEOGRAFIA E ESTATÍSTICA. Contas Nacionais: Brasil, 1994. http://www.ibge.gov.br (20 maio 2002)

INSTITUTO BRASILEIRO DE GEOGRAFIA E ESTATÍSTICA. Contas Nacionais: Brasil, 1995. http://www.ibge.gov.br (20 maio 2002)

INSTITUTO BRASILEIRO DE GEOGRAFIA E ESTATÍ́STICA. Contas Nacionais: Brasil, 1990. http://www.ibge.gov.br (20 maio 2002)

KUMAR, N. The revolution in retailing: from market driven to market driving. Long Range Planning, v.30, n.6, p.830-835, 1997.

LEME, M.F.P. Concentração e internacionalização de capital na indústria brasileira de alimentos. Piracicaba, 1999. 89p. Dissertação (Mestrado) - Escola Superior de Agricultura "Luiz de Queiroz", Universidade de São Paulo. 
LEME, M.F.P.; TEIXEIRA, C.P. Parecer no 515/COGSE/SEAE/MF sobre Aquisição da Supermercados Mogiano Ltda. pela Companhia Brasileira de Distribuição. Brasília: Secretaria de Acompanhamento Econômico, 22 dez. 2000. 12p.

LEPSCH, S. Precificação em supermercado: um estudo exploratório junto a vinte empresas brasileiras. São Paulo, 1996. 97p. Dissertação (Mestrado) - Faculdade de Economia, Administração e Contabilidade, Universidade de São Paulo. 97p.

LOJUDICE, M. Oligopólio ganha 'franja' no varejo. Valor. Caderno Empresas, São Paulo, 08 set. 2000. p.B-3.

MALTA, C.B.; NASCIMENTO, S. Varejo vai à forra contra a indústria. Gazeta Mercantil, São Paulo, 18 jul. 1999. p.A-1.

MARTINEZ, C. A aposta do varejo no popular. Jornal Gazeta Mercantil. Caderno Análises \& Perspectivas, São Paulo, 10 ago. 2000. p.A-3.

McGILVRAY, J.W. Linkages, key setor and development strategy. In: LEONTIEF, W. (Ed.). Structure, system and economic policy. Cambridge: Cambridge University Press, 1977. cap.4, p.49-56.

MIERNYK, W.H. Elementos de análise do insumo-produto. São Paulo: Atlas, 1974. $164 p$.

MILLER, R.E.; BLAIR, P.D. Input-output analysis: foundations and extensions. Englewood Cliffs: New Jersey: Prentice-Hall, 1985. 464p.

MIYAZAWA, K. Input-output analysis and the structure of income distribution. Berlim: Springer-Verlag, 1976. 135p. (Mathematical economics-Lectures notes in economics and mathematical systems, 116)

PACHECO, P. Donos da gôndola. Dinheiro, p.68, set. 2000. 
RASMUSSEN, P. N. Studies in intersectoral relations. Amsterdam: North-Holland, 1956. 210p.

SAAB, W.G.L.; GIMENEZ, L.C.P.; RIBEIRO, R.M. Supermercado no Brasil: o movimento das grandes empresas. Brasília: BNDES, Gerência Setorial de Comércio e Serviços, 2000. n.22. 22p.

SAAB, W.G.L.; GIMENEZ, L.C.P.; RIBEIRO, R.M. Supermercado no Brasil: o movimento das empresas menores. Brasília: BNDES, Gerência Setorial de Comércio e Serviços, 2000. n.24. 20p.

SANTOS, A.M.M.M.; GIMENEZ, L.C.P. Reestruturação do comércio varejista

e de supermercados. Brasília: BNDES, Gerência Setorial de Comércio e Serviços, 2001. n.24. 26p.

SESSO FILHO, U.A. Crescimento e desempenho de redes de supermercados na década de 90. In: ANGELO, C.F.; SILVEIRA, J.A.G. Varejo competitivo. São Paulo: Atlas, 2001a. cap.1, p.21-44.

SESSO FILHO, U.A. Estabilização econômica e consumo de alimentos no Brasil. Informações Fipe, n.253, p.36-39, out. 2001 b.

SESSO FILHO, U.A. Indústria e varejo de alimentos: internacionalização de capital, concentração e poder de mercado. Informações Fipe, n.255, p.20-23, dez. 2001c.

SILVA, G.M. de O.; FAMÁ, R. O recente movimento de fusões e aquisições no setor de supermercados: possíveis causas e conseqüências (compact disc). In: SEMINÁRIOS EM ADMINISTRAÇÃO JR., 1., São Paulo, 1999. Anais. São Paulo: Universidade de São Paulo, Faculdade de Economia, Administração e Contabilidade, 1999. 
SONIS, M.; HEWINGS, G.J.D. Errors and sensitivity input-output analysis: a new approach. In: MILLER, R.E.; POLENSKE, K.R.; ROSE, A.Z. (Ed.). Frontiers of input-output analysis. New York: Oxford University Press, 1989.

SUPERHIPER. Revista da Associação Brasileira de Supermercados. São Paulo, v.27, n.309, maio 2001. 218p.

SUPERHIPER. Revista da Associação Brasileira de Supermercados. São Paulo, 1974-

SUPERHIPER. Revista da Associação Brasileira de Supermercados. São Paulo, v.28, n.320, maio 2002. 202p.

SUPERMERCADO MODERNO. São Paulo, v.26, n.3, mar. 1995. 176p.

SUPERMERCADOS ampliam lançamentos. Folha de São Paulo. Caderno Negócios, São Paulo, 18 maio 1998. p.1.

TAKAOKA, H.; NAVAJAS, P.F. Intercâmbio eletrônico de dados (EDI): vantagens para o varejo. In: ANGELO, C.F.; SILVEIRA, J.A.G. Varejo competitivo. São Paulo: Atlas, 1997. p.19-33.

WILDER, A.; SESSO FILHO, U.A. Distribuição de alimentos: transformações na década de 90. Informações Fipe, n.257, p.28-30, fev. 2002. 